UNIVERSIDADE DE SÃO PAULO

FACULDADE DE ECONOMIA, ADMINISTRAÇÃO E CONTABILIDADE DE RIBEIRÃO PRETO

DEPARTAMENTO DE ADMINISTRAÇÃO

\title{
INOVAÇÃO TECNOLÓGICA EM MULTINACIONAIS BRASILEIRAS: ESTUDO MULTICASO SOBRE GESTÃO DO PORTFÓLIO DE PROJETOS DE NOVOS PRODUTOS
}

ROGÉRIO SOUZA DA MATA

Orientadora: $\operatorname{Prof}^{\mathrm{a}}$. Dr ${ }^{\mathrm{a}}$. Geciane Silveira Porto

Ribeirão Preto 


\author{
Reitora da Universidade de São Paulo \\ Prof $^{\text {a }}$ Dr $^{\text {a }}$ Suely Vilela Sampaio \\ Pró-reitor de Pós-Graduação \\ Prof. Dr. Armando Corbani Ferraz
}

Diretor da Faculdade de Economia, Administração e Contabilidade de Ribeirão Preto

Prof. Dr. Rudinei Toneto Júnior

Coordenador de Pós-Graduação

Prof. Dr. André Lucirton Costa

Chefe do Departamento de Administração

Prof. Dr. Marcio Mattos Borges de Oliveira 
ROGÉRIO SOUZA DA MATA

\section{INOVAÇÃO TECNOLÓGICA EM MULTINACIONAIS BRASILEIRAS: ESTUDO MULTICASO SOBRE GESTÃO DO PORTFÓLIO DE PROJETOS DE NOVOS PRODUTOS}

Dissertação apresentada ao Mestrado do Programa de Pós-Graduação em Administração de Organizações do Departamento de Administração da Faculdade de Economia, Administração e Contabilidade de Ribeirão Preto, da Universidade de São Paulo, para obtenção do título de Mestre em Administração.

Orientadora: Prof ${ }^{\mathrm{a}}$. Dr ${ }^{\mathrm{a}}$. Geciane Silveira Porto.

Ribeirão Preto 


\section{AUTORIZO A REPRODUÇÃO TOTAL OU PARCIAL DESSE TRABALHO, POR QUALQUER MEIO, PARA FINS DE ESTUDO OU PESQUISA, DESDE QUE CITADA A FONTE.}

\section{FICHA CATALOGRÁFICA}

Mata, Rogério Souza da

Inovação tecnológica em multinacionais brasileiras: estudo multicaso sobre gestão do portfólio de projetos de novos produtos. Ribeirão Preto, 2008.

192 p. : il. ; $30 \mathrm{~cm}$

Dissertação de Mestrado apresentada à Faculdade de Economia, Contabilidade e Administração de Ribeirão Preto/USP. Departamento de Administração.

Orientadora: Porto, Geciane Silveira.

1. Inovação tecnológica 2. Multinacionais brasileiras 3. Desenvolvimento de produtos. 4. Gestão de projetos 5. Gestão do portfólio. 


\section{FOLHA DE APROVAÇÃO}

\section{Rogério Souza da Mata}

Inovação tecnológica em multinacionais brasileiras: estudo multicaso sobre gestão do portfólio de projetos de novos produtos.

Dissertação apresentada ao Mestrado do Programa de Pós-Graduação em Administração de Organizações do Departamento de Administração da Faculdade de Economia, Administração e Contabilidade de Ribeirão Preto, da Universidade de São Paulo, para obtenção do título de Mestre em Administração.

Aprovada em:

Banca Examinadora:

Prof. Dr.

Instituição: Assinatura:

Prof. Dr.

Instituição: Assinatura:

Prof. Dr.

Instituição: Assinatura: 
Dedico este trabalho ao meu pai Valdivino (in memoriam) 


\section{AGRADECIMENTOS}

À minha esposa Angélica e à minha filha Maria Rita, por me incentivarem e compreenderem minha ausência durante os trabalhos de pesquisa de campo e as incontáveis horas em frente ao computador. Agradeço também à minha mãe e aos meus irmãos, que sempre me apoiaram.

À minha orientadora, $\operatorname{Prof}^{\mathrm{a}} \operatorname{Dr}^{\mathrm{a}}$ Geciane Silveira Porto, por sua valiosa contribuição na minha formação profissional, na elaboração dessa pesquisa e, principalmente, por acreditar no meu potencial.

À Prof ${ }^{\mathrm{a}} \operatorname{Dr}^{\mathrm{a}}$ Simone Vasconcelos Ribeiro Galina e ao Prof. Dr. Edgard Monforte Merlo pelas valiosas contribuições na qualificação dessa pesquisa.

Às empresas que participaram dessa pesquisa, contribuindo com entrevistas, documentos e com a revisão dos relatórios. Agradeço especialmente à empresa SMAR Equipamentos Industriais por me permitir cursar o mestrado durante o horário comercial.

Ao GETEC e ao GINEBRA pelo apoio institucional.

A todos os colegas da turma do mestrado, vindos de vários cantos do Brasil, com os quais tive a oportunidade de conviver e aprender valiosas lições de vida.

Aos Professores e Professoras do PPGAO, por sua dedicação e profissionalismo, estendendo o agradecimento a todos os demais profissionais da FEA de Ribeirão Preto. 
"As pessoas que vencem neste mundo são as que procuram as circunstâncias de que precisam e, quando não as encontram, as criam".

Bernard Shaw

"Que a inspiração chegue, não depende de mim. A única coisa que posso fazer é garantir que ela me encontre trabalhando".

Pablo Picasso 


\section{RESUMO}

MATA, Rogério Souza da. Inovação tecnológica em multinacionais Brasileiras: estudo multicaso sobre gestão do portfólio de projetos de novos produtos. 2008.192 p. Dissertação de mestrado - Faculdade de Economia, Administração e Contabilidade de Ribeirão Preto, Universidade de São Paulo, Ribeirão Preto, 2008.

Esta pesquisa investigou quatro empresas multinacionais brasileiras em busca de suas práticas na gestão do portfólio de projetos de novos produtos. Por meio de um estudo multicaso, a pesquisa abrangeu diversos aspectos dessa gestão, tais como estratégia para novos produtos e tecnologias; mecanismos de identificação de oportunidades e fontes de idéias para novos produtos; estrutura e recursos de engenharia e P\&D; técnicas preferidas para análise, seleção e priorização de projetos; mecanismos de acompanhamento no desenvolvimento dos novos produtos e revisão do portfólio. Um conjunto de práticas de gestão foi identificado e comparado a quatro modelos teóricos, o que levou à conclusão que as empresas gerenciam seu portfólio de forma heterogênea. Mesmo assim, tais práticas produzem como resultado final uma importante vantagem competitiva e podem auxiliar outras empresas na busca pela excelência na gestão da inovação por meio da gestão do seu portfólio de projetos de novos produtos. Ainda que não seja possível generalizar as conclusões acerca dos casos, os resultados apontam diversas intersecções entre as práticas encontradas nas empresas e os modelos teóricos, convergindo para um conjunto comum de práticas gerenciais que podem favorecer o desempenho de outras organizações, além de contribuir com subsídios para futuras pesquisas.

Palavras-chave: inovação tecnológica, multinacionais brasileiras, gestão do portfólio de projetos, desenvolvimento de novos produtos. 


\begin{abstract}
MATA, Rogério Souza da. Technology innovation in Brazilian multinationals: multicase study on new product portfolio management. 2008. 192 p. Master's degree dissertation Faculty of Economics, Business Administration and Accounting of Ribeirao Preto, University of Sao Paulo, Ribeirao Preto, 2008.

This research has investigated four Brazilian multinational companies looking for their most used practices in managing their portfolio of new product projects. To accomplish this goal, a multi-case study was undertaken. Several aspects of the new products portfolio management were explored, such as product innovation strategy; R\&D structure and resources; opportunities seizing mechanisms and sources for new product ideas; preferred project evaluation and selection techniques; decision makers' preferences and profiles; new product development measures and portfolio periodic revision. Based on this investigation, a set of practices was identified and compared to four theoretical models. It was found that the companies manage their portfolio in heterogeneous ways. However, such practices contribute to the overall innovation in the companies and produce a substantial competitive advantage. Indeed, such practices can also help other companies in achieving new products portfolio management excellence. Although the conclusions that followed through can not be generalized to a management model, the results can substantially aid other companies in leveraging their portfolio management performance and also be a relevant contribution for future research.
\end{abstract}

Key words: technology innovation, Brazilian multinationals, project portfolio management, new product development. 


\section{LISTA DE FIGURAS}

FIGURA 1 - GESTÃO DE PROJETOS NO CONTEXTO DA INOVAÇÃO TECNOLÓGICA ………………………………..... 6

FIGURA 2 - SOBREPOSIÇÃO DE FASES NOS MODERNOS PROCESSOS DE DESENVOLVIMENTO DE PRODUTOS ............... 9

FIGURA 3 - MODELO DE REFERÊNCIA PARA DESENVOLVIMENTO DE PRODUTOS …….......................................... 10

FigURA 4 - MATRIZ VOLUME-VARIEDADE E ESTRATÉGIAS EM OPERAÇÕES DE MANUFATURA ……………............. 12

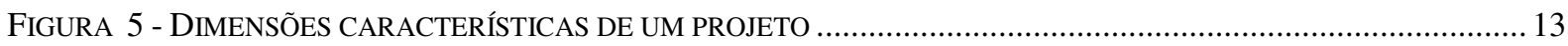

FigURA 6 - MODELO DE GESTÃo DO PORTFÓLIO DE RABECHINI JÚNIOR, MAXIMIANO E MARTINS .......................... 18

FigURA 7 - VALOR COMERCIAL ESPERADO E ÁRVORE DE DECISÃo PARA AVALIAÇÃO DE PROJETOS........................ 19

FIGURA 8 - ESTRUTURA GERAL DO PROCESSO DE GESTÃO DO PORTFÓLIO DE PROJETOS ……………………….......2

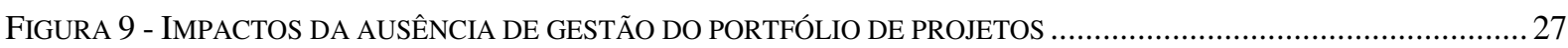

FIGURA 10 - PRINCIPAIS ABORDAGENS USADAS NA GESTÃO DO PORTFÓLIO DE NOVOS PRODUTOS..........................2 28

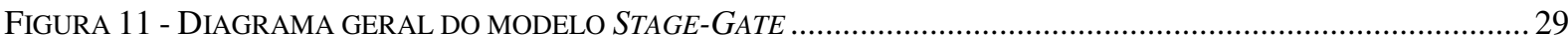

FIGURA 12 - PROCESSOS DA GESTÃO DO PORTFÓLIO DE PROJETOS SEGUNDO O PMI ................................................. 38

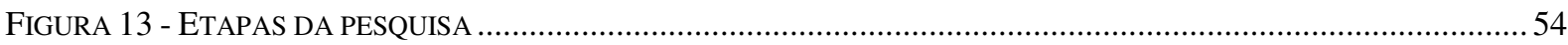

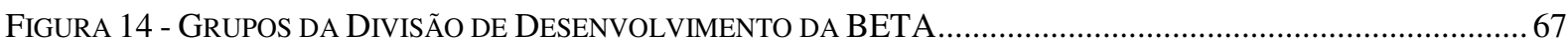

FIGURA 15 - RELACIONAMENTOS EXTERNOS DO COMITÊ CIENTÍFICO E TECNOLÓGICO DA WEG ….......................... 70

FIGURA 16 - EXEMPLO DE GRÁFICO DE BOLHAS USADO PARA SELEÇÃO DE PROJETOS NA ALFA ............................ 89

FIGURA 17 - RELAÇÃO ENTRE AS ETAPAS DO PDP E TIPOS DE PROJETOS NA ALFA …………………………........91

FIGURA 18 - FASES DO PROCESSO DE GESTÃO DO PORTFÓLIO DE NOVOS PRODUTOS NA ALFA.................................96

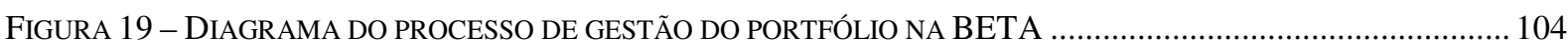

FIGURA 20 - FASES DO PROCESSO DE DESENVOLVIMENTO DE PRODUTOS DA TIGRE ………………………........... 105

FIGURA 21 - EXEMPLO DE GRÁFICO DE BOLHAS DA ATRATIVIDADE X INVESTIMENTO USADO NA TIGRE............. 107

FIGURA 22 - DIAGRAMA DO PROCESSO DE GESTÃO DO PORTFÓLIO NA TIGRE ........................................................ 109

FIGURA 23 - ESQUEMA ILUSTRATIVO DAS ETAPAS PARA APROVAÇÃO DE UM NOVO PROJETO NA WEG ................. 112

FIGURA 24 - RECURSOS UTILIZADOS NO DESENVOLVIMENTO DE NOVOS PRODUTOS E TECNOLOGIAS..................... 113

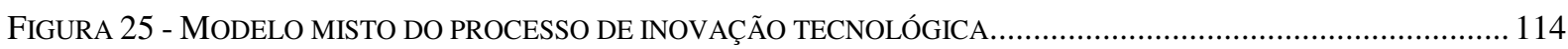

FIGURA 26 - INTERAÇÃO ENTRE GESTÃO ESTRATÉGICA E OPERACIONAL DO PORTFÓLIO ………………………...... 139 


\section{LISTA DE QUADROS}

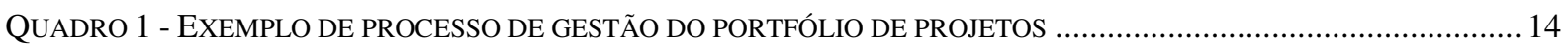

QUADRO 2 - DIFERENTES ABORDAGENS DA GESTÃO DO PORTFÓLIO DE PROJETOS ................................................15

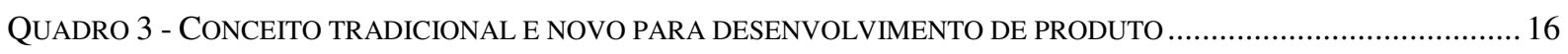

QUADRO 4 - COMPARAÇÃO ENTRE GERENCIAMENTO DE PROJETOS, PROGRAMA E PORTFÓLIO .................................17

QUADRO 5 - POSSÍVEIS ATIVIDADES E MÉTODOS DO PROCESSO DE SELEÇÃO DE PROJETOS DO PORTFÓLIO..............26

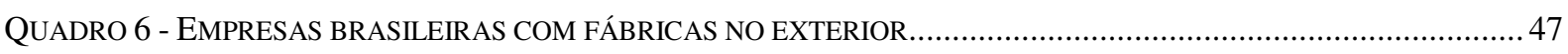

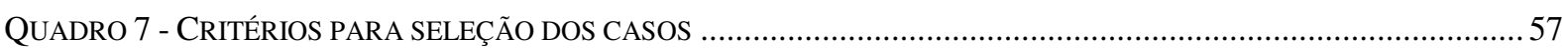

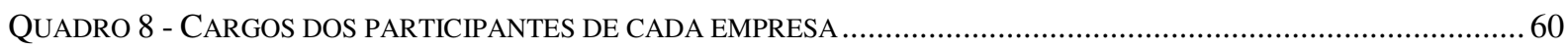

QUADRO 9 - RELAÇÃO ENTRE OS PROCESSOS DOS MODELOS TEÓRICOS DE REFERÊNCIA .....................................62

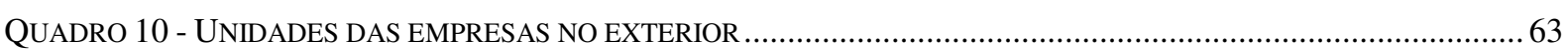

QUADRO 11 - RESUMO COMPARATIVO DA ESTRUTURA DE DESENVOLVIMENTO DE PRODUTOS .............................74

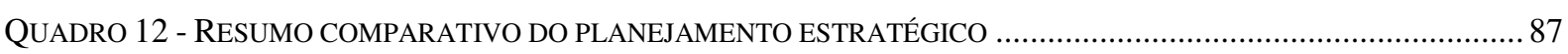

QUADRO 13 - RESUMO COMPARATIVO DA FORMAÇÃO DO PORTFÓLIO ................................................................ 115

QUADRO 14 - RESUMO COMPARATIVO DO ACOMPANHAMENTO E REVISÃO DO PORTFÓLIO ................................. 126

QUADRO 15 - COMPARAÇÃO ENTRE OS CASOS E O MODELO DE RABECHINI JÚNIOR, MAXIMIANO E MARTINS..... 145

QUADRO 16 - COMPARAÇÃO ENTRE OS CASOS E O MODELO DE ARCHER E GHASEMZADEH .................................146

QUADRO 17 - VERIFICAÇÃO DAS PROPOSIÇÕES DE ARCHER E GHASEMZADEH NAS EMPRESAS ............................ 147

QUADRO 18 - COMPARAÇÃO ENTRE OS CASOS E O MODELO DE COOPER .......................................................... 148

QUADRO 19 - COMPARAÇÃO ENTRE OS CASOS E O MODELO DO PMI............................................................ 149

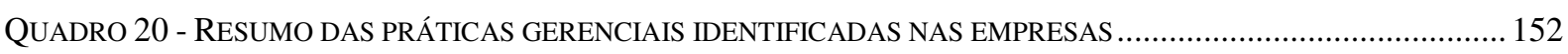

QUADRO 21 - MATURIDADE EM GESTÃO DE PROJETOS DAS EMPRESAS ........................................................... 153

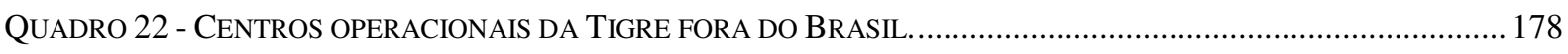




\section{SUMÁRIO}

I - INTRODUÇÃ 0 .................................................................................................................................................

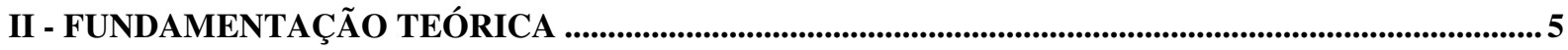

2.1. INOVAÇÃO TECNOLÓGICA E DESENVOLVIMENTO DE PRODUTOS …….......................................5

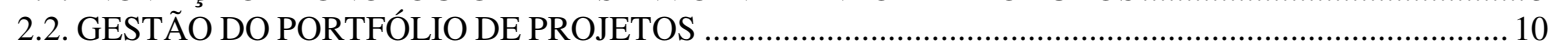

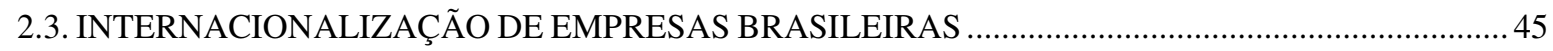

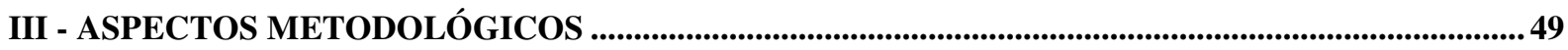

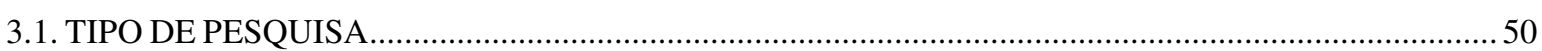

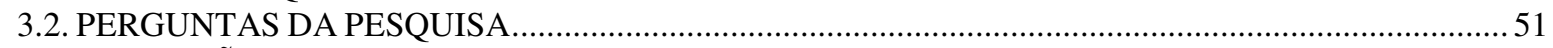

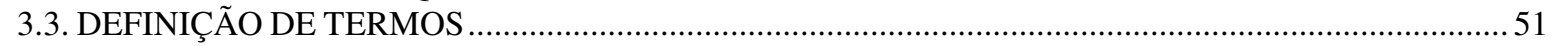

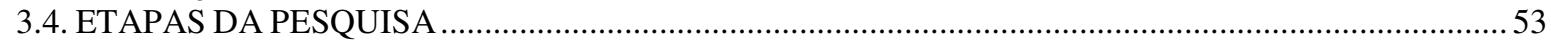

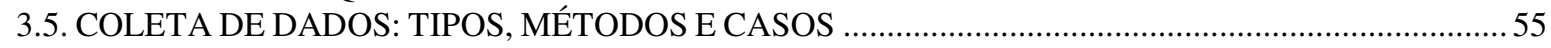

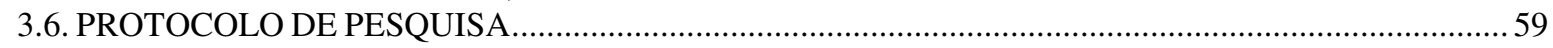

IV - APRESENTAÇÃ̃ E ANÁLISE DOS RESULTADOS ...................................................................61

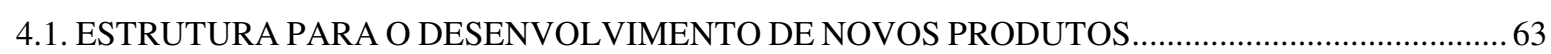

4.2. PLANEJAMENTO ESTRATÉGICO DE NOVOS PRODUTOS E TECNOLOGIAS .............................. 74

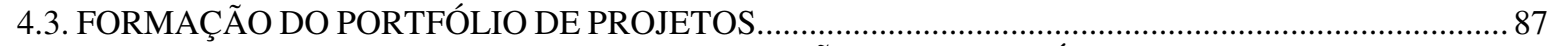

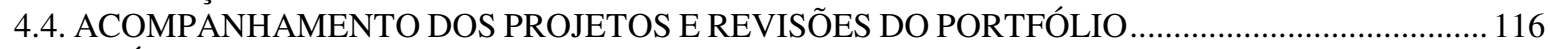

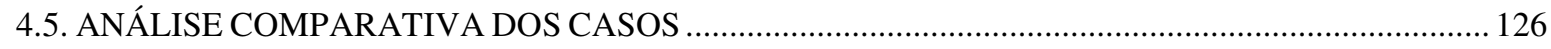

V - CONSIDERAÇÕES FINAIS....................................................................................................................... 151

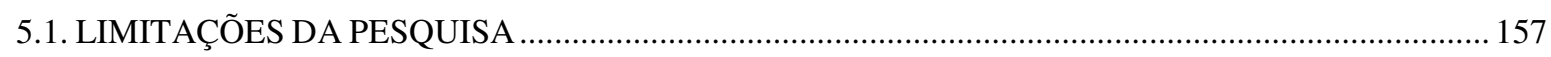

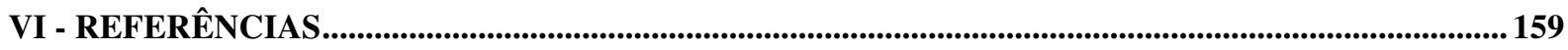

ANEXO A - ROTEIRO DE ENTREVISTA............................................................................................................166

ANEXO B - MODELO DE RELATÓRIO PARA ESTUDO DE CASO ........................................................172

ANEXO C - DADOS E FATOS SOBRE A ALFA.................................................................................... 173

ANEXO D - DADOS E FATOS SOBRE A BETA ...............................................................................174

ANEXO E - DADOS E FATOS SOBRE A TIGRE .................................................................................... 175

ANEXO F - DADOS E FATOS SOBRE A WEG ……....................................................................................... 179 


\section{I - INTRODUÇÃO}

A gestão do portfólio de projetos é um tema de fundamental importância para a indústria brasileira, especialmente a exportadora, que enfrenta uma violenta concorrência no mercado internacional. O crescimento no número das organizações que orientam suas atividades por projetos, em particular aquelas que empreendem o desenvolvimento de produtos, tem sido freqüentemente citado na literatura acadêmica (RABECHINI JÚNIOR; CARVALHO, 2005; KRUGLIANSKAS et al., 2006; PATAH; CARVALHO, 2006).

A conquista de novos mercados e a ferrenha competição global impulsionam as empresas a inovar e lançar novos produtos constantemente, tanto no mercado doméstico quanto para exportação e até mesmo por meio de filiais em outros países. Goulart (2004) afirma que a decisão de internacionalizar as atividades está ligada à preocupação da empresa em ganhar experiência gerencial e operacional. O estudo das empresas multinacionais brasileiras é extremamente relevante, pois essas empresas têm ocupado um espaço cada vez maior no âmbito do processo de globalização da economia, apresentando resultados muitas vezes superiores aos da média de seu segmento (ALTMANN, 2005).

Uma das ferramentas para que as empresas brasileiras enfrentem o árduo desafio da internacionalização é a inovação tecnológica, fundamentada no desenvolvimento de novos produtos e serviços, no estabelecimento de parcerias estratégicas e no desenvolvimento de competências essenciais (OECD, 2005; NONAKA; TAKEUCHI, 1995; PRAHALAD; HAMEL, 1990).

Clark e Wheelwright (1992) apontam quatro objetivos principais para a estratégia de inovação de produtos:

a. A criação, definição e seleção de uma série de projetos que proporcionarão produtos e processos superiores.

b. A integração e coordenação das tarefas funcionais, técnicas e as unidades organizacionais envolvidas nas atividades de desenvolvimento em um determinado espaço no tempo.

c. O gerenciamento do esforço de desenvolvimento para a consecução dos objetivos de negócios de uma maneira eficiente e eficaz o quanto for possível.

d. A criação e melhoramento das capacidades necessárias para que o desenvolvimento de produtos seja uma vantagem competitiva de longo prazo. 
Sendo o desenvolvimento de produtos inerentemente uma atividade de projeto, as empresas de base tecnológica trabalham cada vez mais organizando suas atividades também em torno de projetos. Além disso, a maioria das empresas que inova e desenvolve produtos no Brasil é exportadora, gerando divisas para o país. Empresas que desenvolvem produtos também criam e convertem conhecimento estratégico (NONAKA; TAKEUCHI, 1995; KANNEBLEY JÚNIOR et al., 2004; PMI, 2004; ROZENFELD et al., 2006).

Segundo Kerzner (2000), dois períodos compõem o gerenciamento de projetos: o primeiro, que corresponde ao gerenciamento de projetos tradicional, vai de 1961 a 1990 . O segundo, que se refere ao gerenciamento de projetos moderno, de 1990 até os dias de hoje. Em sintonia com essa divisão, Rabechini Júnior e Carvalho (2005) classificam essas fases temporais como ondas. A primeira onda, que ocorreu entre os anos de 1995 e 2005, foi a onda da expansão, em que o modelo proposto pelo Project Management Institute (PMI), por meio do Project Management Body of Knowledge (PMBoK), despertou interesse em uma série de novos expectadores (setores de tecnologia de informação, telecomunicações, serviços e serviços financeiros). Nessa onda, foram tratadas as questões básicas de gerenciamento de projetos, cujo foco sempre foi na execução do projeto. Além disso, o monitoramento e a análise de desempenho dos principais objetivos do projeto (escopo, prazo, custo e qualidade), com base em indicadores de valor agregado, foram implementados. É difundido, nesta onda, o conceito de gerenciamento de projetos segundo a teoria das restrições (CSILLAG, 1994).

A segunda onda em gerenciamento de projetos teve foco na eficácia. Não é apenas necessário fazer "certo o projeto", mas também fazer "o projeto certo". Assim, o gerenciamento de projetos surge como uma alternativa de inovação à própria atividade gerencial. Em busca da eficácia no gerenciamento de projetos, a empresa pode adotar a gestão do portfólio de projetos, além da implementação de uma estrutura estratégica apropriada na forma de escritórios de projeto, não esquecendo da construção de competências e da maturidade em gestão de projetos em âmbito organizacional (RABECHINI JÚNIOR; CARVALHO, 2005, 2006; RABECHINI JÚNIOR, MAXIMIANO e MARTINS, 2005; PMI, 2006b; MCGRATH, 1996).

Em geral, mesmo empresas de pequeno porte possuem diversos projetos em andamento simultaneamente, ainda que em diferentes estágios: enquanto alguns estão em fase de concepção, outros estão em desenvolvimento, outros sendo lançados no mercado e outros ainda sendo descontinuados (COOPER et al., 1997, 1999, 2001). O gerenciamento desse portfólio de projetos permite às organizações sustentarem suas vantagens competitivas, consistindo em uma evidente oportunidade. O estudo das técnicas de gestão de projetos 
apresenta enormes desafios na medida em que os ciclos de vida dos produtos têm diminuído ano após ano (GARFEIN, $2004^{1}$ apud RABECHINI JÚNIOR et al, 2006).

O gerenciamento do portfólio de projetos é uma alternativa gerencial que pode dar uma grande contribuição aos dirigentes das empresas, proporcionando um exame bem detalhado das dimensões estratégicas que devem nortear o balanceamento da carteira e sua adequada priorização, bem como criar mecanismos de controle e descarte de projetos. Entretanto, sua atuação não deve se limitar apenas à escolha dos projetos, mas também ao planejamento, gerenciamento e medição de performance ao longo do ciclo de vida do produto, confundindo-se de alguma forma com o próprio gerenciamento do ciclo de vida do produto (RABECHINI JÚNIOR; CARVALHO, 2005).

Além de compor o melhor portfólio a cada ciclo de avaliação, maximizando seu valor, é preciso considerar que a dinâmica na demanda pode eventualmente levar a acelerar, cancelar ou adiar projetos já em andamento. Em razão disso, o processo de seleção e priorização deve levar em conta, entre outros fatores, os recursos humanos, financeiros e técnicos disponíveis, os resultados esperados de cada produto e o balanço entre os projetos escolhidos (ARCHER; GHASEMZADEH, 1999; COOPER et al., 1999).

Archer e Ghasemzadeh (1999) apontam a necessidade de realizar pesquisas para determinar quais são as práticas e técnicas preferidas na gestão do portfólio de projetos de novos produtos e para simplificar as técnicas mais úteis e aumentar sua aceitação nas empresas. Além disso, é preciso encontrar as situações nas quais as informações necessárias possam ser fornecidas por dados colhidos de projetos existentes e quais entradas do processo podem ser fornecidas por estimativas ou modelos econômicos. Ainda, examinar qual o escopo das decisões estratégicas que são tomadas fora do contexto do processo de seleção de projetos do portfólio e que permitem facilitar o próprio processo.

Sendo assim, o objetivo principal dessa pesquisa é identificar quais são as práticas de gestão adotadas pelas multinacionais brasileiras na gestão do portfólio de projetos de novos produtos. Considera-se que, se essas empresas conseguem apresentar um desempenho superior na gestão de seu portfólio de projetos de novos produtos, outras empresas podem se basear em suas práticas para melhorar seu próprio desempenho. Para se atingir esse objetivo, torna-se primordial responder à seguinte pergunta: como as multinacionais brasileiras gerenciam seu portfólio de projetos de novos produtos?

\footnotetext{
${ }^{1}$ GARFEIN, S. Strategic Portfolio Management - A smart, realistic and relativity fast way to gain sustainable competitive advantage. Proceedings PMI Global Congress, Toronto, Canada, 2004.
} 
Como desdobramento do objetivo geral, foram definidos os seguintes objetivos específicos:

a. Identificar as práticas de gestão do portfólio de projetos de novos produtos nas empresas multinacionais brasileiras.

b. Verificar se as práticas identificadas nas empresas seguem os modelos teóricos que sinalizam as tendências mais recentes.

c. Comparar as práticas de gestão do portfólio de projetos utilizadas pelas empresas.

d. Identificar a participação das unidades estrangeiras na gestão do portfólio de projetos de novos produtos.

O capítulo 1 situa a gestão do portfólio de projetos de novos produtos no contexto da inovação tecnológica, apresentando os objetivos da pesquisa. No capítulo 2 há a fundamentação teórica sobre inovação tecnológica, gestão do portfólio de projetos e internacionalização de empresas brasileiras. O capítulo 3 descreve os procedimentos metodológicos e o protocolo de pesquisa que orientou o estudo multicaso. Em seguida, a apresentação e análise dos dados coletados, no capítulo 4 . O capítulo 5 apresenta as conclusões e considerações finais. No capítulo 6 lista-se todo o referencial bibliográfico utilizado. Na seção de anexos estão o roteiro de entrevistas, o modelo de relatório elaborado para os estudos de caso, além de dados e fatos sobre as empresas. 


\section{II - FUNDAMENTAÇÃO TEÓRICA}

A fundamentação teórica tem por objetivo fornecer o conhecimento essencial para desenvolvimento da pesquisa e análise dos resultados. A partir dela, foi possível elaborar o protocolo de pesquisa que norteou toda a coleta e análise de dados. Além disso, a fundamentação teórica trouxe à tona conceitos, informações e conclusões de pesquisas anteriores que formaram o alicerce para a construção dos resultados desse trabalho. Nesse capitulo são abordadas três áreas de conhecimento: inovação tecnológica e desenvolvimento de produtos; gestão do portfólio de projetos e internacionalização de empresas brasileiras. É importante ressaltar, porém, que a teoria usada para elaboração dessa pesquisa não se restringe ao conteúdo aqui apresentado, se estendendo a todas as obras referenciadas.

\subsection{INOVAÇÃO TECNOLÓGICA E DESENVOLVIMENTO DE PRODUTOS}

O objetivo da teoria sobre inovação tecnológica e desenvolvimento de produtos utilizada nessa pesquisa foi conectar esses temas com a gestão de projetos e com a gestão do portfólio de projetos. Essa teoria é de fundamental importância para analisar o ambiente onde ocorre o desenvolvimento de produtos nas empresas, que por sua vez, exerce papel determinante nos mecanismos de inovação e de gestão do portfólio de projetos de novos produtos, já que a competitividade das empresas parece depender cada vez mais da capacidade de lançar produtos inovadores. Em conseqüência da globalização, dos avanços tecnológicos, da abrangência cada vez maior nas comunicações e do surgimento de novos modelos de gestão, a vantagem competitiva das empresas passa a depender cada vez mais de sua capacidade de articular sua experiência, sua base de conhecimentos e novas tecnologias para o desenvolvimento e lançamento de novos produtos e serviços. A gestão da inovação é um processo multidisciplinar que envolve várias áreas como: marketing, $\mathrm{P} \& \mathrm{D}$, desenvolvimento integrado de produtos e serviços, produção e operação e, acima de tudo, mudança e desenvolvimento organizacionais. A inovação tem sido uma das estratégias mais eficazes para garantir a sobrevivência e o crescimento das empresas (KRUGLIANSKAS et al., 2006). 
Inovações brilhantes em novos produtos ou processos estão na raiz das grandes fortunas na história da indústria. Porém, o contexto competitivo das organizações está se alterando rapidamente: a imprevisibilidade das demandas e das reações do mercado às novas tecnologias leva as empresas à necessidade de administrar mais eficientemente as inovações de produtos e processos, encarando-as como atividades rotineiras e não mais como grandes feitos históricos. Também podemos perceber intuitivamente que o ciclo de vida dos produtos está cada vez menor. Assim, empresas que adotam a estratégia de apenas seguir as pioneiras correm cada vez mais o risco de desaparecerem. O desenvolvimento de novos produtos e processos está passando a ser encarado não mais como episódios esporádicos, mas sim como uma função que a administração da empresa deve promover diariamente, sendo que a gestão da inovação em processos e produtos é um dos fatores essenciais para o sucesso da organização (DE MAIO et al., 1994).

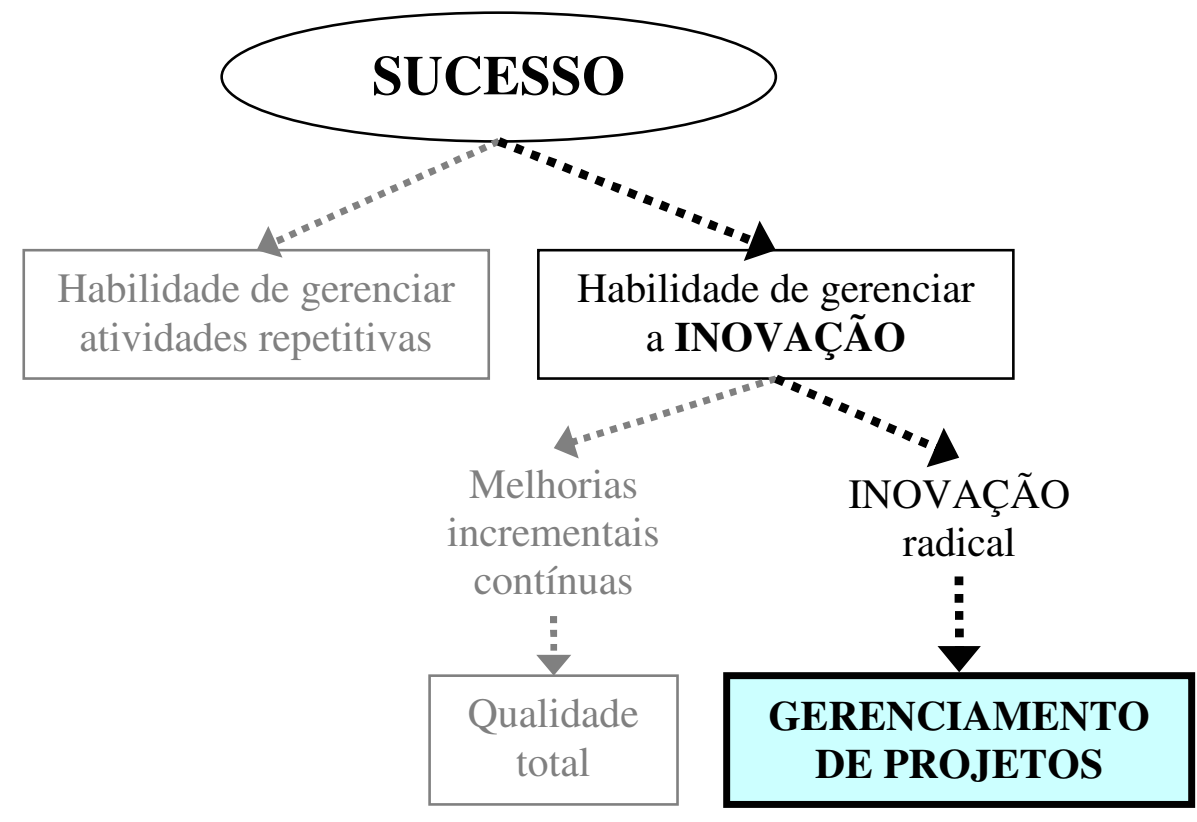

Figura 1 - Gestão de projetos no contexto da inovação tecnológica Fonte: adaptado de De Maio et al. (1994), p. 179.

Ainda que De Maio et al. (1994) apontem as inovações radicais como sendo aquelas que dependem diretamente da gestão de projetos, as inovações incrementais também podem se beneficiar sobremaneira se forem encaradas também como projetos, uma vez que tendo um risco reduzido, por se tratarem de melhorias ou evoluções, elas possuem um grau de incerteza menor, com maior previsibilidade, menor risco e maior controle. A tecnologia está associada a impactos socioeconômicos resultantes da aplicação de novos materiais, novos processos de fabricação, novos métodos e novos produtos nos meios de produção. Para que uma tecnologia 
criada seja transformada em inovação, essa tecnologia deve ser produzida pelos agentes econômicos (as empresas), disponibilizada para a sociedade e aceita por esta. O processo de inovação tecnológica envolve, então, todo o ciclo que compreende pesquisa básica, pesquisa aplicada, desenvolvimento, produção, marketing, venda, logística, pós-venda e todas as interações e realimentações possíveis entre essas fases (REIS, 2004).

Sbragia, Kruglianskas e Camargos (1998) argumentam que a inovação é uma atividade complexa que começa com a concepção de uma idéia, passa por um processo de solução de um ou mais problemas, culminando com a utilização real de um novo status de valor econômico e social. A maioria das inovações é concebida a partir do reconhecimento de uma necessidade do mercado. A capacidade tecnológica, somada a esta necessidade, permite que a idéia se transforme em um projeto de inovação que segue um determinado processo para poder apresentar-se na forma de um novo produto, processo ou serviço.

A inovação tecnológica envolve investimentos e a utilização de novos conhecimentos ou a combinação nova de conhecimentos existentes, tendo como um de seus objetivos melhorar o desempenho da empresa (OECD, 2005). Nesse contexto, a inovação pode ser classificada em quatro tipos distintos:

a. Inovação de Produto: é o desenvolvimento de um novo produto ou o aperfeiçoamento significativo de um produto já existente.

b. Inovação de Processo: é a execução de um método novo ou significativamente melhorado de produção ou de distribuição. Isto inclui mudanças significativas nas técnicas, nos equipamentos ou softwares.

c. Inovação de Mercado: é a execução de um novo método de marketing, envolvendo mudanças significativas no produto, na colocação do produto no mercado, nas estratégias promocionais e no estabelecimento do preço do produto.

d. Inovação Organizacional: é a execução de um método organizacional novo, englobando mudanças significativas nas práticas gerenciais internas e externas, com a criação de novas práticas de gestão.

No contexto da inovação tecnológica, o desenvolvimento de produtos aparece como uma das formas da empresa conseguir um desempenho diferenciado, por meio do desenvolvimento de produtos que venham de encontro às reais necessidades do mercado. Assim, o processo de desenvolvimento de produto utilizado pela empresa, bem como sua estrutura e suas competências, estão intimamente ligados à forma com a qual a empresa conseguirá inovar em novos produtos. 


\subsubsection{Desenvolvimento de novos produtos}

Utterback (1996) sugere a existência de três fases de desenvolvimento associadas à taxa de inovação e às evoluções no processo, produto, concorrência e organização: fluida, transitória e específica. Nessa perspectiva, o autor afirma que as inovações radicais no produto ocorrem até o surgimento de um produto dominante e, a partir desse ponto, o foco do pessoal de P\&D se concentra nas inovações incrementais. À medida que a taxa de inovação do produto diminui, a taxa de inovação do processo aumenta, pois no período de maior inovação no produto os processos são geralmente primitivos e ineficientes. As inovações do produto e processo são, portanto, interdependentes.

Quanto ao ambiente competitivo, Utterback (1996) considera que à medida que a taxa de inovação no produto decresce e aumenta no processo, é comum a ocorrência de mudanças no ambiente competitivo. Inicialmente, quando há ausência de consenso quanto às possibilidades e características do produto, existem enormes incertezas, tanto para os produtores, como para os clientes. Mas, quando o consenso se cristaliza em torno de um projeto dominante, a concorrência entre empresas rivais se estabiliza em favor das empresas com maior capacidade de inovação e integração de processo, e com aptidões de desenvolvimento técnico e de engenharia mais desenvolvidas. À medida que a indústria se estabiliza, passam a existir apenas poucas empresas (quatro ou cinco seria o número típico). As fases fluida, transitória e específica estão, portanto, associadas tanto à taxa de inovação como às dimensões subjacentes do processo, do produto, da concorrência e da organização. $\mathrm{Na}$ fase fluida, ocorre um grande número de mudanças simultaneamente, e o resultado é incerto, em termos de produto, processo, liderança competitiva e estrutura organizacional das empresas. A fase transitória é caracterizada pela aceitação no mercado de uma inovação do produto e o surgimento de um projeto dominante. Na fase específica (ou madura) o valor da relação qualidade-custo torna-se a base da concorrência, onde os produtos são altamente definidos (UTTERBACK, 1996).

Apesar do processo de desenvolvimento de novos produtos estar intimamente relacionado à gestão do portfólio de projetos de novos produtos (GPPNP), ambos não devem ser confundidos. O desenvolvimento de produtos é um dos processos da GPPNP, que pode assumir inúmeras configurações, sendo que uma das mais representativas é o processo de $3^{\mathrm{a}}$ geração de Cooper (1994). Nesse processo, cada fase é precedida por uma análise crítica 
indicando se o projeto segue ou não adiante. Porém, em função das necessidades do negócio e das peculiaridades da empresa, é possível que haja alguma sobreposição entre diferentes estágios do processo, conforme ilustrado na figura seguinte:

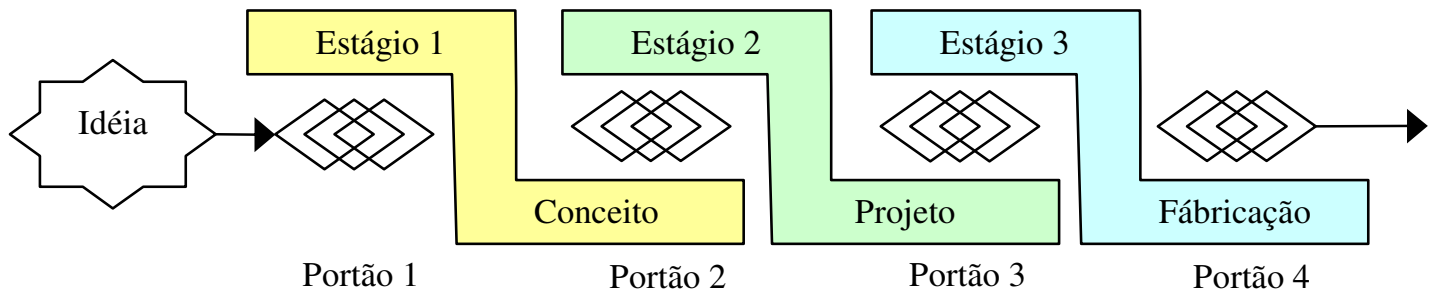

Figura 2 - Sobreposição de fases nos modernos processos de desenvolvimento de produtos Fonte: adaptado de Cooper (1994), p. 5.

Entre outras definições, o desenvolvimento de produtos é o processo a partir do qual informações sobre o mercado são transformadas nas informações e bens necessários para a produção de um produto com fins comerciais. Assim, o processo de desenvolvimento de produtos é parte inerente da GPPNP, recebendo e fornecendo dados dele (CLARK; FUJIMOTO, 1991).

Uma das formas de se caracterizar o processo de desenvolvimento de produtos é por meio das seguintes dimensões, as quais estão presentes no modelo de referência apresentado por Rozenfeld et al. (2005):

a. Atividades e fases: Conceber Produto, Conceituar Produto, Projetar Produto e Processo, Homologar Produto, Homologar Processo e Ensinar Empresa. O modelo de referência apresenta as atividades dispostas em cada uma destas etapas.

b. Recursos: é compostos por todos os conceitos e filosofias, métodos e técnicas, ferramentas e sistemas que podem ser aplicados no processo de desenvolvimento de produto.

c. Organização: refere-se não só à estrutura organizacional responsável e executora das atividades de desenvolvimento de produto como também aos elementos como cultura, qualificação profissional, formas de comunicação entre os indivíduos, dentre outros, ligados aos aspectos de organização do trabalho.

d. Informação: dimensão que representa o fluxo de informações existente neste processo, os dados, sua estrutura e o formato como estes circulam (relatórios, fichas, telas de computador, dentre outros). 


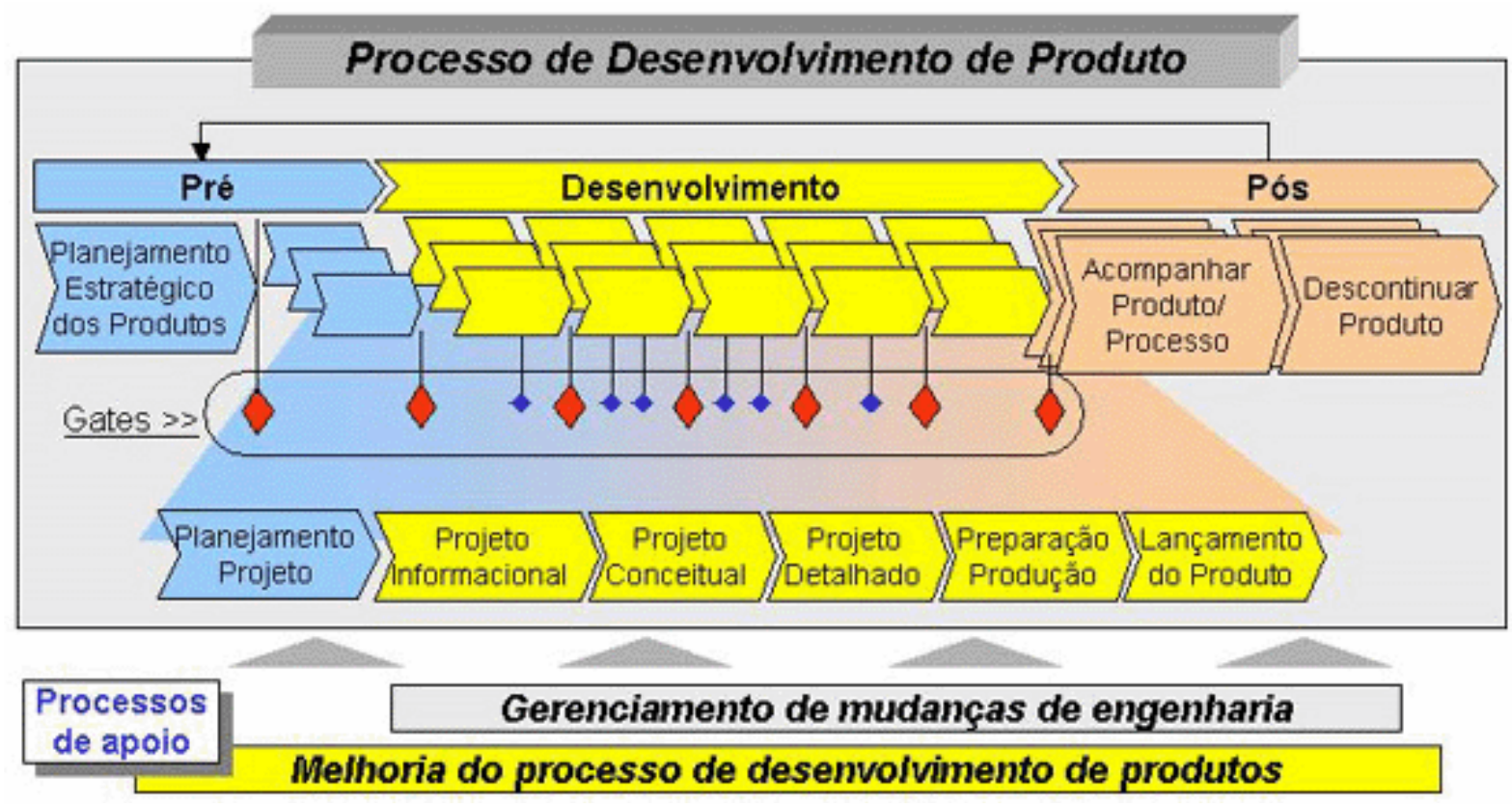

Figura 3 - Modelo de referência para desenvolvimento de produtos

Fonte: Rozenfeld et al. (2005), p. 37.

\subsection{GESTÃO DO PORTFÓLIO DE PROJETOS}

A gestão do portfólio pode ser definida como sendo uma administração centralizada de um ou mais portfólios, o que inclui a identificação, priorização, autorização, gestão e controle de projetos, programas e outras atividades, para atingir os objetivos estratégicos do negócio. Há muitos tipos de gestão do portfólio: portfólio de investimentos, portfólios de produtos comercializados, portfólio de recursos, dentre outros. Porém, para todos os propósitos dessa pesquisa, a gestão do portfólio se refere apenas a projetos, em especial, aqueles cujo resultado esperado é um novo produto para a empresa. Enquanto a gestão de projetos e de programas tem se concentrado tradicionalmente em "fazer certo o trabalho", a gestão do portfólio se concentra em "fazer o trabalho certo" (PMI, 2006b).

Mesmo entre pequenas empresas é raro encontrar um único projeto em andamento. Para perseguir e capturar as várias oportunidades do mercado, as organizações empreendem diversos projetos simultaneamente, utilizando um mesmo conjunto de recursos (pessoas, dinheiro, equipamentos, dentre outros). Ao tirar uma foto do portfólio de projetos de uma empresa em um determinado momento, é possível ver projetos em vários estágios: alguns sendo iniciados, alguns entrando em produção, outros sendo cancelados e outros ainda em fase de concepção (COOPER et al., 1997, 1999, 2001; RABECHINI JÚNIOR; CARVALHO, 
2005; RABECHINI JÚNIOR; MAXIMIANO; MARTINS, 2005; ARCHER; GHASEMZADEH, 1999).

Segundo McGrath (1996), os projetos em andamento competem pelos recursos da organização. Tanto a alta direção quando os gerentes e coordenadores de projetos devem estar atentos para que cada projeto atinja seus objetivos específicos e ao mesmo tempo os objetivos gerais (estratégicos) da empresa. Nesse sentido é que a gestão estratégica e operacional da empresa deve ser ampla o suficiente para incorporar todo o portfólio de projetos com sua dinâmica evolutiva. Mas isso não é tarefa fácil, e depende de inúmeros fatores, como a maturidade da empresa no processo de desenvolvimento de produtos, como pode ser visto no quadro seguinte:

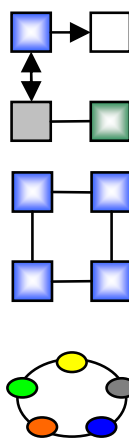

Estágio 0: gestão informal baseada em práticas individuais, experiência pessoal, baixa estruturação e pouca troca de informações. Primórdios da revolução industrial.

Estágio 1: excelência baseada nas capacidades isoladas de cada função, pouca cooperação entre as diversas funções da empresa. Estruturação inicial das organizações, com alguma troca de informações, mas baixa produção de conhecimento. Paradigma da produção em massa.

Estágio 2: excelência na execução de projetos isolados, por meio do alinhamento entre as funções, desde a concepção até a comercialização do produto. Foco na intensa troca de informações, mas pouca ênfase no compartilhamento de conhecimentos. Paradigma da qualidade.

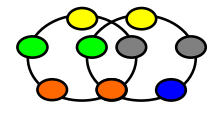

Estágio 3: excelência em múltiplos projetos, por meio da eficiência na seleção e execução de projetos, alinhamento entre processos e uso de plataformas. Grande ênfase na troca de conhecimentos. Paradigma da flexibilidade.

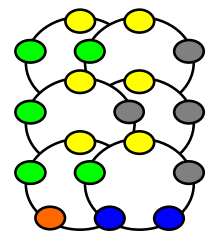

Estágio 4: excelência em desenvolvimento colaborativo pelo intenso relacionamento entre os processos das funções internas e externas à organização. Intensa criação e conversão de conhecimento, rompendo a fronteira entre a organização e a sociedade. Paradigma da inovação e gestão do conhecimento.

Quadro 1 - Estágios de maturidade em desenvolvimento de novos produtos Fonte: adaptado de McGrath (1996), p 35.

\subsubsection{Conceitos de projeto e portfólio}

As definições para esses termos variam de acordo com a época e o contexto:

Um projeto é uma organização de pessoas dedicadas que visam atingir um propósito e objetivo específico. Projetos geralmente envolvem gastos, ações ou empreendimentos únicos de altos riscos e devem ser completados em uma certa data por um montante de dinheiro, dentro de alguma expectativa de desempenho. No mínimo, todos os projetos necessitam de ter seus objetivos bem definidos e recursos suficientes para poderem desenvolver as 
tarefas requeridas (TUMAN, $1983^{1}$ apud RABECHINI JÚNIOR; CARVALHO, 2005, p. 12).

Um processo único, que consiste em um grupo de atividades coordenadas e controladas com datas para início e término, empreendido para alcance de um objetivo conforme requisitos específicos, incluindo limitações de tempo, custo e recursos (ISO 10006, 1997² apud RABECHINI JÚNIOR; CARVALHO, 2005, p. 12).

Um esforço complexo, usualmente com duração menor que três anos, formado por tarefas inter-relacionadas, realizadas por várias organizações, com objetivo, orçamento e cronograma bem definidos (ARCHER; GHASEMZADEH, 1999, p. 208).

Um empreendimento temporário para criar um produto, serviço ou resultado único (PMI, 2004, p. 5).

Além das definições anteriores, é conveniente olhar também sob o ponto de vista da matriz volume-variedade de Slack et al. (2002), onde um projeto está no limite em que o volume é mínimo (único), a variedade é máxima (é singular) e o incremento de capacidade, integração e automação da tecnologia são mínimos. Desta forma, "projetos demandam tratamento diferenciado no que concerne ao seu gerenciamento, habilidades, técnicas e ferramentas específicas" (PATAH; CARVALHO, 2006, p. 163).

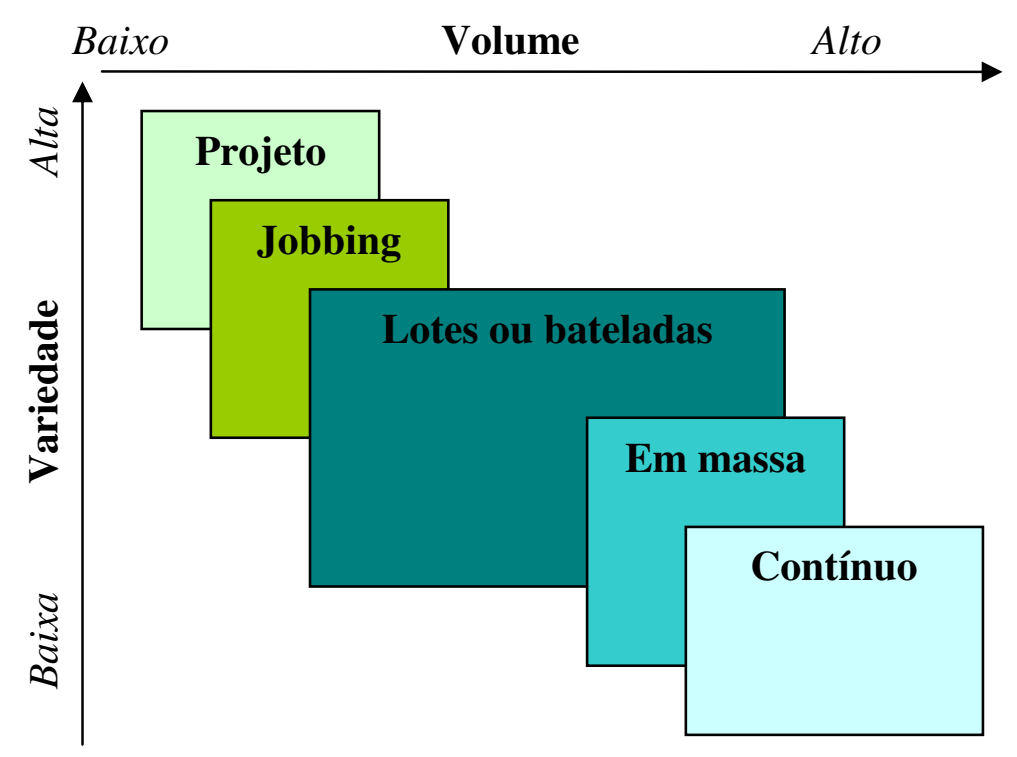

Figura 4 - Matriz volume-variedade e estratégias em operações de manufatura Fonte: Slack et al. (2002), p. 129.

\footnotetext{
${ }^{1}$ TUMAN, G. J. Development and implementation of effective project management information and control systems. In: CLELAND, D. I.; KING, W. R. Project Management Handbook. New York: Van Nostrand Reinhold, 1983.

${ }^{2}$ ISO 10006:1997, Quality management; Guidelines to quality in project management.
} 
O objetivo da atividade de projeto é satisfazer às necessidades dos consumidores. A atividade de projeto aplica-se tanto a produtos quanto a serviços e sistemas (chamados processos). A atividade de projeto é em si mesma um processo de transformação. O projeto começa com um conceito e termina na tradução desse conceito em uma especificação de algo que pode ser fabricado (SLACK et al., 2002).

O desenvolvimento de novos produtos pode ser definido como a combinação de duas atividades principais: projeto (P\&D) e fabricação (Operações). Contudo, é bastante difícil separar esses dois conceitos no contexto industrial de hoje. Isso implica diretamente na idéia de que o desenvolvimento de novos produtos é um processo interdepartamental (DREJER; GUDMUNDSSON, 2003). Um dos aspectos essenciais que diferenciam um projeto de desenvolvimento de um novo produto é sua alta singularidade, o que torna a incerteza no projeto bastante alta, como podemos ver na figura seguinte:

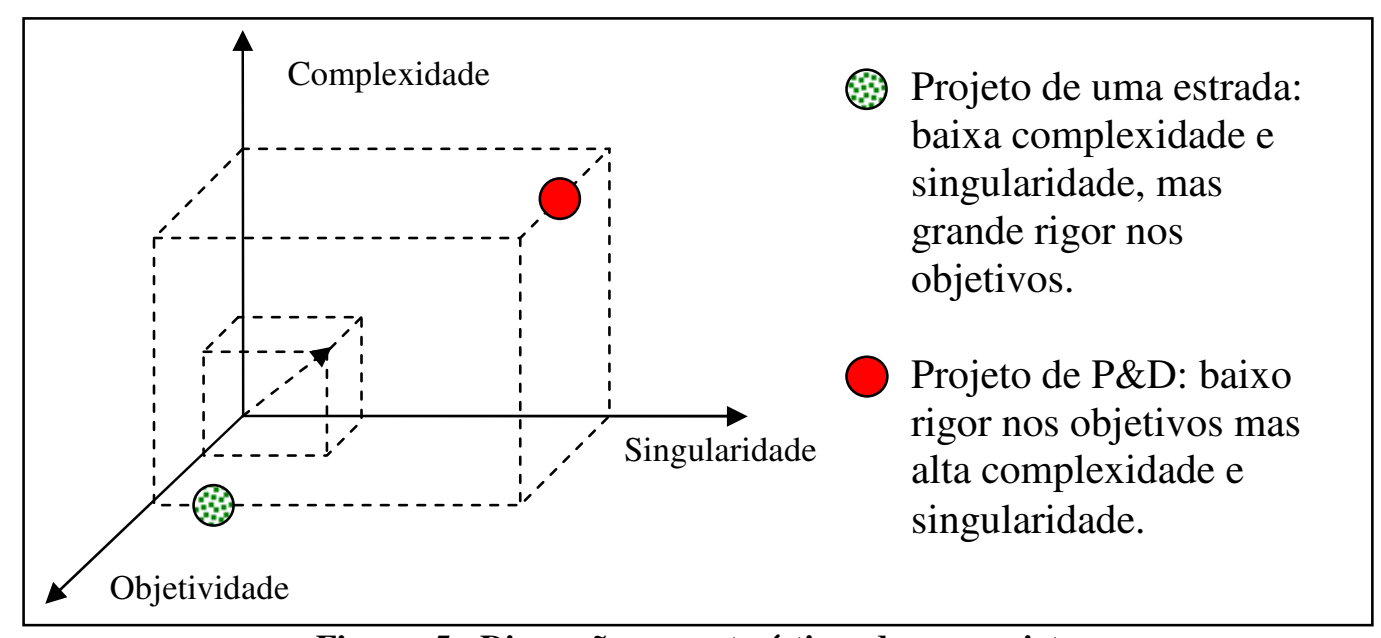

Figura 5 - Dimensões características de um projeto Fonte: adaptado de Carvalho e Rabechini Júnior (2005), p. 13.

Cada tipo de projeto tem seu lugar característico na figura anterior. Um projeto de um novo modelo, baseado em uma plataforma existente, possui em geral singularidade e complexidades menores que o projeto de uma nova plataforma. No ambiente competitivo atual, os gerentes de projetos enfrentam a competição acirrada por recursos escassos, enquanto assistem suas janelas de oportunidades se reduzirem cada vez mais. Além disso, novos projetos são continuamente adicionados pela alta direção, enquanto outros são alterados ou cancelados como reação às mudanças no contexto do negócio ou nas condições do mercado. Some-se a isso as constantes variações nas demandas dos clientes internos e externos. Como resultado, os recursos necessários para levar adiante todos os projetos desejados são quase sempre muito superiores aos recursos disponíveis, o que leva à necessidade de priorizar e selecionar. $\mathrm{O}$ aumento da diversidade e da imprevisibilidade 
tecnológica, combinado à diminuição simultânea do ciclo de vida dos produtos, requer uma gestão de projetos eficaz e consistente (DYE; PENNYPACKER, 2000).

As características dos projetos podem ser vistas também sob a óptica de conjunto. Assim, a administração de um conjunto de projetos foi expressa na definição de programas: um grupo de projetos gerenciados de forma coordenada. Além dos projetos e dos programas, uma nova forma gerencial tem se apresentado no mundo dos negócios, mas pouco explorada pelas empresas brasileiras: gestão do portfólio, ou gerenciamento de projetos e programas de forma sistêmica (PMI, 2004).

É conveniente abordar uma outra definição sobre o que vem a ser um portfólio de projetos de novos produtos. Para Martinsuo e Lehtonen (2006), portfólio é um grupo de projetos que compartilham e competem pelos mesmos recursos na organização. A gestão do portfólio, por sua vez, é um processo decisório dinâmico, onde uma lista de projetos ativos é definida e constantemente revisada e atualizada (COOPER et al., 1997). Pode também ser entendido como a atividade periódica que envolve a seleção de propostas de novos projetos e projetos já em andamento que atendam aos objetivos declarados da organização sem exceder os recursos disponíveis ou violar outras restrições (ARCHER; GHASEMZADEH, 1999). Crawford (2002 ${ }^{1}$ apud Rabechini Júnior, Maximiano e Martins, 2005) apresenta o gerenciamento do portfólio visto como um processo gerencial que é guiado pelos passos apresentados no quadro seguinte:

\begin{tabular}{|l|l|}
\hline \multicolumn{1}{|c|}{ PASSOS } & \multicolumn{1}{|c|}{ DETALHES } \\
\hline Identificação de projetos & $\begin{array}{l}\text { Consideração dos aspectos estratégicos e táticos. } \\
\text { Consideração dos projetos em andamento. } \\
\text { Formar relação inicial de projetos. }\end{array}$ \\
\hline $\begin{array}{l}\text { Alinhamento de } \\
\text { oportunidades às } \\
\text { estratégias e à organização }\end{array}$ & $\begin{array}{l}\text { Identificação e seleção de critérios de avaliação estabelecendo pesos } \\
\text { para avaliação dos projetos e programas. } \\
\text { Hierarquização de projetos e programas. }\end{array}$ \\
\hline $\begin{array}{l}\text { Avaliação de } \\
\text { investimentos e recursos }\end{array}$ & Pontos de decisão ou filtros levando-se em conta os elementos financeiros. \\
\hline $\begin{array}{l}\text { Desenvolvimento } \\
\text { do portfólio }\end{array}$ & $\begin{array}{l}\text { Formação do portfólio, que subsidiará decisões sobre os projetos } \\
\text { considerando-se priorização dos mesmos, possibilidades de exclusão, de } \\
\text { inclusão de recursos, etc. } \\
\text { O portfólio poderá também ser um instrumento para revisão do escopo dos } \\
\text { projetos. }\end{array}$ \\
\hline Gerenciamento do portfólio & $\begin{array}{l}\text { Desenvolver estruturação dos projetos em termos de escopo, prazos e } \\
\text { custos. Acompanhar o andamento e liberar recursos } \\
\text { Comunicar os interessados, entre outras ações gerenciais. }\end{array}$ \\
\hline
\end{tabular}

Quadro 1 - Exemplo de processo de gestão do portfólio de projetos

Fonte: adaptado de Crawford (2002 apud Rabechini Júnior, Maximiano e Martins, 2005), p. 419.

\footnotetext{
${ }^{1}$ CRAWFORD, J. K. The Strategic Project Office: a guide to improving organizational performance. New York: Marcel Dekker Inc, 2002. 374 p.
} 
É preciso entender também como a gestão do portfólio de projetos se relaciona com a gestão de múltiplos projetos. Os gerentes de desenvolvimento de produtos muitas vezes enfrentam umas das maiores causas de falha na gestão de projetos: a necessidade inevitável de administrar as interdependências e interações entre os projetos, assegurando sua mútua compatibilidade em termos do portfólio. Atualmente parece existir uma idéia comum de que todos os projetos ativos são parte do portfólio. Contudo, um grupo de projetos independentes, ou tratados de forma independente entre si, não constituem um portfólio, mas apenas um grupo de projetos consumindo tempo e os recursos. Na melhor das hipóteses, esses projetos foram selecionados pela alta direção tendo em vista uma estratégia de longo prazo (COOPER et al. 1997; DYE; PENNYPACKER, 2000; PMI, 2006a).

Há assim, uma certa confusão com relação ao significado dos termos "gestão do portfólio de projetos" e "gestão de múltiplos projetos". É possível encontrar referências a duas linhas de pesquisa que usam esses mesmos termos. Essas linhas de pesquisa possuem os seguintes significados principais (DYE; PENNYPACKER, 2000):

a. Gestão do portfólio de projetos: seleção e priorização de projetos com objetivos estratégicos de criação de valor.

b. Gestão de múltiplos projetos: alocação dos recursos da organização entre os vários projetos ativos.

Essas duas linhas de pesquisa não são mutuamente exclusivas, mas sim, são totalmente complementares. Podem-se também modelar essas duas abordagens como sendo processos na organização que interagem constantemente (DYE; PENNYPACKER, 2000):

\begin{tabular}{|c|c|c|}
\cline { 2 - 3 } \multicolumn{1}{c|}{} & GESTÃO DO PORTFÓLIO & GESTÃO DE MÚLTIPLOS PROJETOS \\
\hline Propósito & Seleção e priorização de projetos & $\begin{array}{c}\text { Alocação de recursos entre os projetos } \\
\text { selecionados }\end{array}$ \\
\hline Foco & Estratégico & Operacional (tático) \\
\hline Ênfase do planejamento & $\begin{array}{c}\text { Médio-longo prazo (revisão anual } \\
\text { ou trimestral) }\end{array}$ & Tática (revisão diária) \\
\hline Responsabilidade & $\begin{array}{c}\text { Executivos sêniores e alta } \\
\text { administração }\end{array}$ & Gerentes de projetos, gerentes de recursos \\
\hline
\end{tabular}

\section{Quadro 2 - Diferentes abordagens da gestão do portfólio de projetos}

Fonte: adaptado de Dye e Pennypacker (2000), p. 1.

Há uma tendência generalizada nos mecanismos de priorização de projetos em considerar todos os projetos como sendo o número um: todos os projetos são considerados prioritários. Entretanto, os projetos devem ser priorizados com base em sua importância e contribuição relativa à estratégia global. Cada projeto deve ser priorizado em relação aos demais, levando em conta as mudanças técnicas e comerciais no momento da avaliação. 
Infelizmente, a maioria dos gerentes, em especial os gerentes de projetos, não estão em posição de controlar ou alterar a prioridade dos projetos. Então, os gerentes de projetos, assim como os gerentes de recursos, devem continuamente se perguntar algumas questões críticas:

a. Os recursos estão alocados para os projetos com maior prioridade?

b. Os recursos dos projetos estão sendo totalmente utilizados?

c. Os projetos estão sendo finalizados no prazo planejado, dentro do orçamento e com a qualidade necessária?

A visão mais tradicional do desenvolvimento de produtos é a de que o processo acontece a partir de um único projeto. À luz das mudanças percebidas no mercado, nas demandas dos consumidores e clientes e no desenvolvimento de modelos de produtos, parece natural que o processo de desenvolvimento de produtos também sofra mudanças na forma como é administrado (DYE; PENNYPACKER, 2000). A maioria dos modelos tradicionais de desenvolvimento de produto é excelente na integração entre fases de projeto e produção, permitindo a redução do tempo para colocar o produto no mercado. Entretanto, consideram apenas um projeto de cada vez, não sendo adequados para ir além de um único produto, ou seja, não consideram adequadamente o portfólio de projetos. A abordagem pela gestão do portfólio é cada vez mais necessária, tanto para economizar recursos quanto para compartilhar soluções entre os projetos (DYE; PENNYPACKER, 2000). A visão de projeto único deve ceder lugar a uma visão de múltiplos produtos (DREJER; GUDMUNDSSON, 2003):

\begin{tabular}{|c|c|c|}
\hline & VISÃO DE PRODUTO ÙNICO & VISÃO DE MÙLTIPLOS PRODUTOS \\
\hline Mercado & $\begin{array}{l}\text { Mercado facilmente segmentado em } \\
\text { grandes segmentos homogêneos }\end{array}$ & Individualizado e bastante heterogêneo \\
\hline Cliente & $\begin{array}{l}\text { Tem desejos e todos são } \\
\text { considerados igualmente importantes }\end{array}$ & $\begin{array}{l}\text { Tem desejos e necessidades. As necessidades } \\
\text { são geralmente mais diferenciadoras que os } \\
\text { desejos. }\end{array}$ \\
\hline Projeto para quê? & $\begin{array}{l}\text { Funções do produto derivadas da } \\
\text { perspectiva do cliente }\end{array}$ & Projeto considera várias perspectivas \\
\hline Integração & $\begin{array}{l}\text { Desenvolvimento de produto é } \\
\text { função de um único departamento }\end{array}$ & $\begin{array}{c}\text { Desenvolvimento de produto é uma função } \\
\text { interdepartamental que inclui produção, } \\
\text { marketing, finanças }\end{array}$ \\
\hline $\begin{array}{c}\text { Processo de } \\
\text { desenvolvimento de } \\
\text { produto } \\
\end{array}$ & Linear e baseado em consenso & Interativo e altamente dialético \\
\hline Foco do produto & $\begin{array}{c}\text { Um único projeto de novo produto de } \\
\text { cada vez }\end{array}$ & $\begin{array}{l}\text { O portfólio de produtos é gerenciado por meio } \\
\text { de uma plataforma de pensamento estratégico }\end{array}$ \\
\hline Organização & $\begin{array}{c}\text { Desenvolvimento do produto } \\
\text { acontece internamente à organização }\end{array}$ & $\begin{array}{l}\text { Desenvolvimento do produto é disperso por } \\
\text { uma rede de organizações }\end{array}$ \\
\hline
\end{tabular}

Quadro 3 - Conceito tradicional e novo para desenvolvimento de produto

Fonte: adaptado de Drejer e Gudmundsson (2003), p. 213. 
Kruglianskas et al. (2006), também reconhecem diferenças entre a gestão de projetos, múltiplos projetos (programa) e do portfólio de projetos, resumidas no quadro seguinte:

\begin{tabular}{|c|c|c|c|}
\cline { 2 - 4 } \multicolumn{1}{c|}{} & $\begin{array}{c}\text { GERENCIAMENO DE } \\
\text { PROJETOS }\end{array}$ & $\begin{array}{c}\text { GERENCIAMENTO DE } \\
\text { PROGRAMA }\end{array}$ & $\begin{array}{c}\text { GERENCIAMENTO } \\
\text { DO PORTFÓLIO }\end{array}$ \\
\hline Escopo & $\begin{array}{c}\text { Atingir um resultado } \\
\text { predefinido (com base na } \\
\text { contribuição do projeto } \\
\text { para um dado objetivo). }\end{array}$ & $\begin{array}{c}\text { Buscar um objetivo } \\
\text { predefinido, como parte da } \\
\text { estratégia da organização. }\end{array}$ & $\begin{array}{c}\text { Implementar a estratégia } \\
\text { da organização } \\
\text { (implementação da } \\
\text { estratégia como um todo). }\end{array}$ \\
\hline $\begin{array}{c}\text { Número de } \\
\text { projetos }\end{array}$ & Um. & $\begin{array}{c}\text { Vários, mas todos } \\
\text { relacionados a um objetivo } \\
\text { específico. }\end{array}$ & Todos. \\
\hline Projeção de tempo & Finito, predefinido. & Finito. & Processo contínuo. \\
\hline $\begin{array}{c}\text { Tomada de } \\
\text { decisões }\end{array}$ & Ao final de cada etapa. & $\begin{array}{c}\text { Em momentos determinados } \\
\text { no planejamento dos } \\
\text { projetos/programa. }\end{array}$ & $\begin{array}{c}\text { Continuamente (ideal). } \\
\text { Freqüentemente. }\end{array}$ \\
\hline Resultados & Resultado do projeto. & $\begin{array}{c}\text { Contribuição a um ou mais } \\
\text { objetivos específicos. }\end{array}$ & $\begin{array}{c}\text { Otimização dos resultados } \\
\text { das iniciativas de } \\
\text { mudanças. }\end{array}$ \\
\hline
\end{tabular}

Quadro 4 - Comparação entre gerenciamento de projetos, programa e portfólio

Fonte: Kruglianskas et al. (2006), p. 99.

Sob outro ponto de vista, a ausência de recursos no gerenciamento do portfólio, problema comumente relatado pelas empresas, também pode ser vista como a tentativa de levar a cabo mais projetos do que os recursos disponíveis permitem, ou, nas palavras de Cooper e Edgett (2003), ausência de foco no desenvolvimento de novos produtos. No estudo conduzido pelos autores, $44 \%$ das organizações confessaram tentar desenvolver um número excessivo de projetos. Esse mesmo estudo revelou nove razões principais pelas quais as empresas caem na armadilha do excesso de projetos:

a. Pressão para lançar "qualquer produto" no mercado.

b. Relutância em perder investimentos já realizados.

c. Resistência em cancelar projetos "quase" terminados.

d. Resistência de executivos em cancelarem projetos de "estimação".

e. Não há nada melhor para ser desenvolvido.

f. Inexistência de mecanismos para cancelamento de projetos.

g. Desconhecimento sobre gestão de portfólios.

h. Não pode dizer não a um cliente chave.

i. Inabilidade dos executivos para cancelar projetos. 


\subsubsection{Modelos teóricos de referência para gestão do portfólio}

Os modelos de gerenciamento do portfólio têm a função básica de ajudar os executivos a responder questões sobre como: (a) acelerar o processo de inovação; (b) aumentar o valor dos portfólios ao longo do tempo; (c) reduzir os ciclos de desenvolvimento de novos produtos; (d) desenvolver mais produtos como os mesmos recursos de P\&D; (e) desenvolver as competências necessárias para atingir os objetivos esperados; (f) integrar as respostas às perguntas anteriores e maximizar o retorno sobre o investimento (ROUSSEL; SAAD; ERICKSON, 1991). Partindo dessa definição quatro modelos teóricos foram selecionados como referência para delinear a realização dessa pesquisa: Rabechini Júnior, Maximiano e Martins (2005), Cooper (1994), Archer e Ghasemzadeh (1999) e PMI (2006b). Os critérios usados para seleção dos modelos foram abrangência e popularidade do modelo, acesso à bibliografia, confiabilidade dos autores e presença de diferentes perspectivas.

\subsubsection{Modelo de Rabechini Júnior, Maximiano e Martins}

Esse modelo sintetiza as atividades da gestão do portfólio de projetos em seis processos, sendo bastante útil para analisar a gestão do portfólio em empresas que estão iniciando essa prática ou que já a implementam de forma parcial. No modelo de gerenciamento do portfólio de projetos proposto por Rabechini Júnior, Maximiano e Martins (2005), há seis dimensões a serem consideradas, ilustradas na figura seguinte:

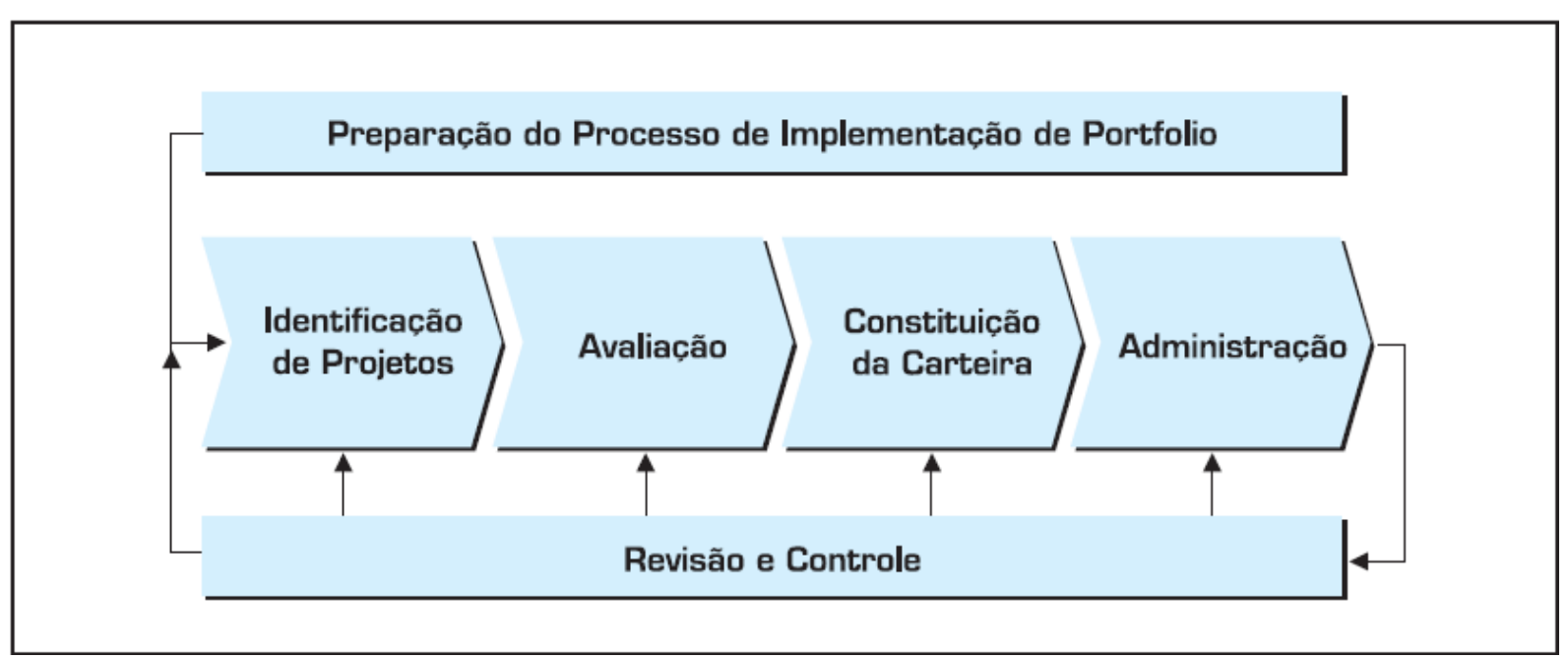

Figura 6 - Modelo de gestão do portfólio de Rabechini Júnior, Maximiano e Martins

Fonte: Rabechini Júnior, Maximiano e Martins (2005), p. 423. 
A primeira dimensão refere-se à preparação do processo de implementação da gestão do portfólio em uma organização. Nesta dimensão o contexto estratégico é delineado. Inclui a análise do ambiente interno e externo e a avaliação de fatores determinantes das estratégias traçadas. Os interessados precisam conhecer de forma ampla o modelo de negócio para enquadrar os projetos e avaliá-los corretamente. Além da necessidade de entendimento dos elementos estratégicos da organização e do modelo de negócios, é necessário conhecer profundamente a metodologia de avaliação de projetos propriamente dita (RABECHINI JÚNIOR; MAXIMIANO; MARTINS, 2005). Este processo deve contemplar os seguintes elementos:

a. Identificação dos critérios de avaliação: os administradores da organização devem mostrar claramente seus objetivos e o gerente do portfólio deverá entender os aspectos e indicadores pretendidos pela alta administração.

b. Estabelecimento de pesos para tais critérios: são graus para diferenciar a importância de cada critério levantado anteriormente. Para Cooper et al. (2001), o estabelecimento de critérios estratégicos e táticos deve levar em conta, ainda, fatores de orientação técnica e comercial. Uma das formas de estimar esses fatores é elaborar uma análise de valor para o projeto, como ilustra a figura seguinte:

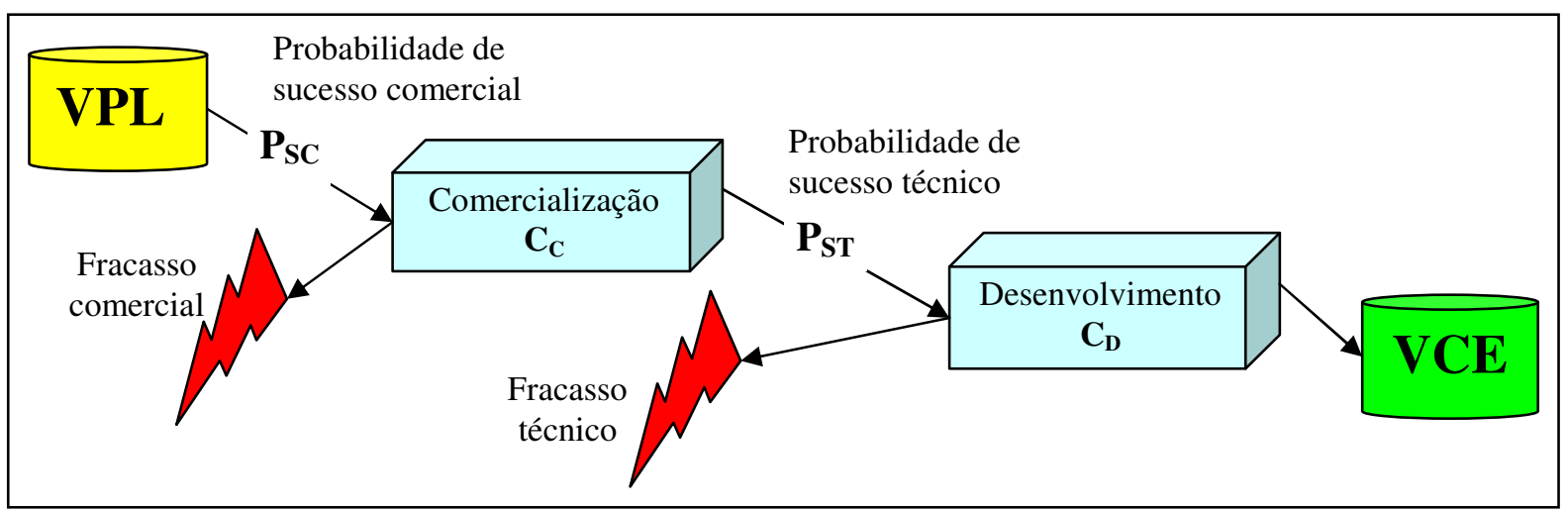

Figura 7 - Valor Comercial Esperado e árvore de decisão para avaliação de projetos Fonte: adaptado de Cooper et al. (1997), p. 16.

A segunda dimensão, a identificação de projetos, visa buscar todas as iniciativas de cada área da organização, para serem reunidas de forma coerente e consistente. Essa dimensão deverá considerar as informações mínimas sobre cada projeto. Em geral, espera-se que os gerentes tenham dados mínimos sobre seus projetos, tais como objetivos, informações sobre prazo e custo, premissas a serem realizadas, indicadores de acompanhamento, restrições e 
riscos. Uma lista completa com os projetos deve ser elaborada ao final desta etapa (RABECHINI JÚNIOR; MAXIMIANO; MARTINS, 2005).

Uma vez estabelecida uma lista de projetos é preciso iniciar a terceira dimensão tratada no modelo, que se refere à avaliação. Seu objetivo é produzir uma lista de projetos prioritários, agregando informações relevantes a esses empreendimentos. Para isto, deve-se inicialmente proporcionar a realização de rodadas de análise com a participação de avaliadores credenciados pela organização e, com elas, estabelecer as notas para cada critério, projeto a projeto (RABECHINI JÚNIOR; MAXIMIANO; MARTINS, 2005). Os conceitos de avaliação do portfólio desenvolvidos por Cooper e Edgett (2003) constituem a base para o desenvolvimento das avaliações, que ainda deve considerar as idéias de Martino (1993), que sugere o estabelecimento de comitês formados para consolidar os filtros de uma avaliação do portfólio. Em geral, dois tipos de critérios são tradicionalmente constituídos: os táticos, que avaliam a efetividade dos projetos, e os estratégicos, que se preocupam com o alinhamento dos projetos com os negócios da organização. Um importante aspecto do modelo levado em conta nesta dimensão são as "linhas de corte", baseadas nas informações agregadas. Os projetos que passarem pelos filtros, ou seja, pelas considerações de caráter estratégico e tático, são os candidatos à formação da carteira. A constituição da carteira, quarta dimensão do modelo, visa estabelecer um plano de gerenciamento do portfólio.

Wheelwright e Clark (1992) recomendam ainda o estabelecimento de prazos de até um ano para alocação de recursos de uma carteira de projetos de uma organização. O modelo proposto considera que essa dimensão deverá ser também precedida de um plano agregado para os projetos. Um dos aspectos relevantes desta dimensão é justamente a formação do plano e inserção de novos projetos à carteira, uma vez que estes passam a disputar recursos a partir de sua formação. Para administrar este plano de forma coerente, há a quinta dimensão, que se refere à administração do portfólio. A dimensão da administração foi baseada no modelo de Crawford (2002 ${ }^{1}$ apud Rabechini Júnior, Maximiano e Martins, 2005). Espera-se também que os interessados possam administrar as competências dos recursos humanos, uma vez que o sucesso da carteira depende do desempenho destes (RABECHINI JÚNIOR; MAXIMIANO; MARTINS, 2005).

Finalmente, na dimensão de revisão e controle, os projetos que estão sendo desenvolvidos devem ser acompanhados. Espera-se que o gerente do portfólio se encarregue

\footnotetext{
${ }^{1}$ CRAWFORD, J. K. The Strategic Project Office: a guide to improving organizational performance. New York: Marcel Dekker Inc, 2002. 374 p.
} 
de propor reuniões de acompanhamento, onde os gerentes de projetos devem fornecer informações indicativas do andamento de cada projeto. Com base nestes dados, o gerente do portfólio tomará suas decisões de alteração da constituição da carteira de projetos (RABECHINI JÚNIOR; MAXIMIANO; MARTINS, 2005).

\subsubsection{Modelo de Archer e Ghasemzadeh}

Apesar de ser um modelo voltado para o desenvolvimento de softwares de suporte à gestão, há uma estrutura lógica dos principais processos da gestão do portfólio de projetos de novos produtos que é muito útil para o mapeamento das práticas nas empresas. Sua estrutura apresenta uma realimentação por meio da análise constante dos projetos em desenvolvimento e de novos projetos candidatos a desenvolvimento, utilizando alguma metodologia de seleção, associada à orientação estratégica e informações operacionais sobre o andamento dos projetos (banco de dados). Portanto, não se trata simplesmente de selecionar projetos, mas também de avaliá-los continuamente, adicionando novos e cancelando projetos que porventura não sejam mais interessantes para a organização. Essa estrutura genérica já foi usada por pesquisadores brasileiros como ferramenta para modelar o processo de gestão do portfólio de projetos em uma grande empresa de processamento de transações eletrônicas (RABECHINI JÚNIOR; MAXIMIANO; MARTINS, 2005).

Para Archer e Ghasemzadeh (1999), portfólio é uma coleção de projetos que são desenvolvidos sob a administração de uma unidade organizacional. Cada projeto pode se relacionar com outros ou ser independente, mas devem ser parte de objetivos estratégicos determinados e assim buscar recursos na organização. O modelo apresentado pode ser usado para identificar as fases principais do processo de gestão do portfólio de projetos, já que é uma estrutura lógica que permite capturar os elementos principais do processo em uso nas empresas e traduzir seus modelos específicos para uma estrutura comum. A estrutura proposta pelos autores deixa totalmente flexível a escolha de qual método deve ser usado em cada fase. $\mathrm{Na}$ figura seguinte estão ilustrados os processos desse modelo: 


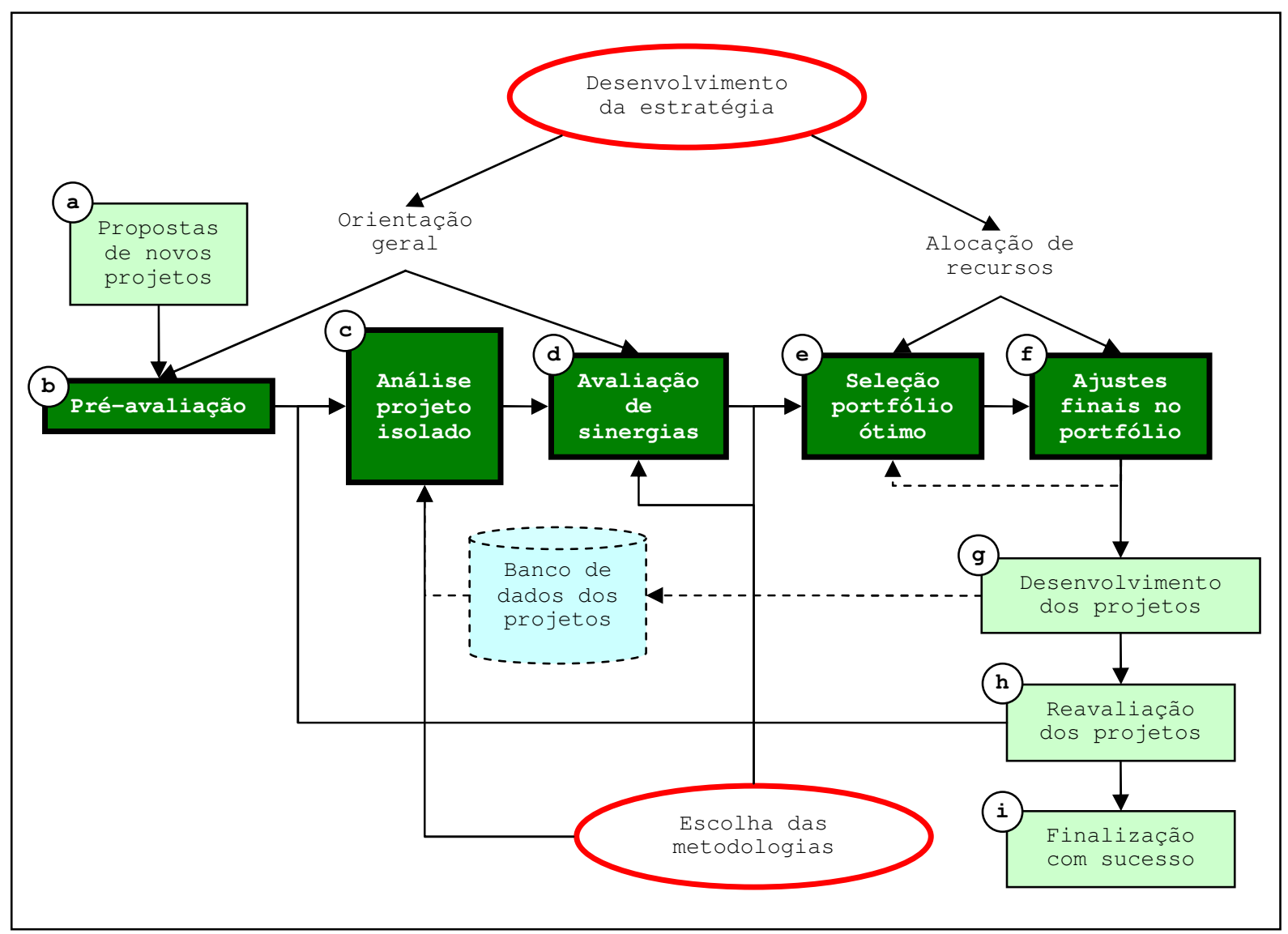

Figura 8 - Estrutura geral do processo de gestão do portfólio de projetos

Fonte: adaptado de Archer e Ghasemzadeh (1999), p. 211.

As caixas de $\mathrm{b}$ a $\mathrm{f}$ da figura anterior representam a espinha dorsal do processo, com suas atividades principais. As elipses representam pré-processos, ou seja, atividades que devem ter sido realizadas em algum momento antes da análise e seleção dos projetos e que fornecem o direcionamento estratégico e técnico para o processo. As demais caixas (a, g até i), representam pós-processos que geram informações durante o desenvolvimento dos projetos para uso nas revisões do portfólio. Além disso, o banco de dados de projetos representa de certa forma alguma estrutura de Tecnologia da Informação (TI) usada como suporte no processo de gestão do portfólio (ARCHER; GHASEMZADEH, 1999). Cada fase do processo é descrita a seguir:

a. Propostas de novos projetos: esse pré-processo inclui todas as idéias coletadas nos mais diversos canais possíveis. Deve fornecer para a próxima fase as propostas formais de projetos de novos produtos, com informações mínimas para a préavaliação.

b. Pré-avaliação: essa fase precede qualquer cálculo ou análise do portfólio e deve assegurar que só passem adiante projetos viáveis e alinhados estrategicamente. Utiliza 
a orientação geral criada durante o processo de desenvolvimento dos objetivos estratégicos do portfólio. Esta fase inclui também uma análise preliminar de viabilidade e estimação dos parâmetros necessários para análises posteriores mais detalhadas. Geralmente haverá um coordenador ou gerente que será fonte de informações adicionais. Projetos considerados indispensáveis para a organização são identificados nessa fase.

c. Análise individual dos projetos: um conjunto comum de parâmetros deve ser calculado para cada projeto em análise, de forma que haja uma mesma base de comparação para todos os projetos. Esses parâmetros são calculados por meio de estimativas de estudos de viabilidade ou de informações de projetos anteriores. Por exemplo: risco comercial e técnico, Valor Presente Líquido (VPL), Taxa Interna de Retorno (TIR), Retorno sobre o Investimento (ROI), Payback, dentre outras.

d. Avaliação dos projetos levando em conta as sinergias: essa fase procurar complementar a fase de pré-avaliação, mas agora utilizando as informações calculadas após a análise individual de cada projeto. Essa fase procura eliminar todos os projetos, grupos ou mesmo famílias inteiras de projetos que não estejam alinhados com os objetivos estratégicos. Normalmente nessa fase são determinados alguns requisitos que os projetos candidatos devem cumprir para que possam continuar no processo de seleção. Tais critérios incluem retorno mínimo, participação de mercado, investimento necessário, dentre outros. Os projetos que não preencherem tais requisitos são descartados da análise, exceto aqueles considerados obrigatórios.

e. Seleção do portfólio ótimo: esta fase representa o uso de um modelo matemático, geralmente implementado em alguma ferramenta computacional, para o cálculo e seleção de um portfólio ótimo, por meio de algoritmos de otimização que procuram a melhor combinação de projetos, dadas as restrições de recursos e objetivos de performance. Os projetos são comparados entre si usando um conjunto comum de parâmetros obtidos nas etapas anteriores.

f. Ajustes finais no portfólio: espera-se que o resultado final seja um portfólio que atenda totalmente, ou o máximo possível, aos objetivos estratégicos da organização. Contudo, nesse estágio final, qualquer lista de projetos que tenha sido obtida ainda pode necessitar de alguma correção. Projetos obrigatórios podem ter sido negligenciados, ou ainda, o portfólio pode não estar devidamente equilibrado em termos dos recursos distribuídos entre os projetos. Pode haver muitos projetos de melhorias, ou ainda muitos projetos em novos produtos ou um número insuficiente de 
projetos para algum objetivo estratégico específico, como exportação. Então, os gestores realizam as modificações que julgarem necessárias na lista de projetos.

g. Desenvolvimento dos projetos: a fase de desenvolvimento, por si só, também é dividida em diversas fases, de acordo com o processo de desenvolvimento de produtos utilizado na empresa (ROZENFELD et al., 2006). Porém, com relação ao processo de gestão do portfólio de projetos, essa etapa deve fornecer informações sobre o andamento de cada projeto, concentradas preferencialmente em um banco de dados, para uso no acompanhamento e revisões do portfólio.

h. Reavaliação dos projetos: as informações de andamento dos projetos, na forma de indicadores, por exemplo, servem para as análises posteriores e reavaliações. $\mathrm{O}$ processo de gestão do portfólio freqüentemente analisa os projetos em andamento e propostos de novos projetos e eventualmente, novos projetos são iniciados e projetos em andamento são cancelados ou suspensos temporariamente.

i. Finalização com sucesso: essa etapa marca o lançamento de produtos, uma vez que o portfólio na verdade nunca é finalizado, pois sempre deve haver novos projetos sendo iniciados, de acordo com a demanda do negócio.

O suporte a cada uma das fases e processos descritos anteriormente se dá través de um conjunto de 11 proposições, em torno das quais esse modelo de referência é construído (ARCHER; GHASEMZADEH, 1999):

- Proposição 1: antes mesmo de se iniciar a seleção de projetos, decisões estratégicas a respeito do foco do portfólio e do orçamento total devem ser tomadas, num contexto amplo que leva em conta fatores internos e externos do negócio.

- Proposição 2: o modelo de gestão do portfólio usado deve ser flexível o suficiente para que os interessados no processo possam escolher antecipadamente técnicas ou metodologias com as quais estejam confortáveis.

- Proposição 3: para simplificar o processo de seleção de projetos do portfólio, ele deve ser organizado em estágios, permitindo aos gestores moverem-se em um caminho lógico na direção dos projetos com maior probabilidade de seleção.

- Proposição 4: os usuários não devem ser sobrecarregados com dados desnecessários, mas devem poder acessar dados relevantes quando for preciso.

- Proposição 5: medidas comuns devem ser escolhidas, mas que possam ser calculadas separadamente para cada projeto em consideração. Isso permitirá uma comparação equânime dos projetos durante o processo de seleção do portfólio. 
- Proposição 6: projetos em andamento que atingirem determinados estágios devem ser reavaliados ao mesmo tempo em que novos projetos são considerados para seleção. Isso permite a geração de um portfólio combinado, sujeito às restrições de recursos, intervalos regulares devido à: (a) finalização ou abandono de projetos, (b) propostas de novos projetos, (c) mudanças no foco estratégico, (d) revisões nos recursos disponíveis e (e) mudanças no ambiente.

- Proposição 7: uma avaliação inicial baseada em critérios cuidadosamente pré-definidos deve ser realizada para eliminar alguns projetos antes mesmo que o processo de seleção do portfólio seja iniciado.

- Proposição 8: as interações entre os projetos por meio da dependência direta ou competição por recursos devem ser consideradas na seleção do portfólio.

- Proposição 9: a seleção do portfólio deve levar em consideração a forma pela qual os recursos disponíveis serão utilizados ao longo do tempo.

- Proposição 10: os gestores devem ter acesso a mecanismos interativos para controlar e alterar qualquer seleção de projetos gerada por qualquer algoritmo ou modelo, e eles devem receber de volta as consequiências de tais mudanças.

- Proposição 11: a seleção de projetos para o portfólio deve ser adaptável a ambientes de suporte à tomada de decisão em grupo.

Enquanto a atividade de desenvolvimento da estratégia procura determinar claramente os objetivos do portfólio de novos produtos e quais recursos estarão disponíveis para seu desenvolvimento, a atividade de escolha das metodologias tem como finalidade definir que técnicas serão usadas na análise dos projetos (ARCHER; GHASEMZADEH, 1999). Pode-se ver no quadro seguinte um resumo dos principais estágios do processo de gestão do portfólio de projetos: 


\begin{tabular}{|c|c|c|c|}
\hline ESTÁGIOS & ESTÁGIO DA SELEÇÃO & ATIVIDADE & POSSÍVEIS TÉCNICAS \\
\hline Pré-processos & $\begin{array}{l}\text { Desenvolvimento da estratégia } \\
\text { do portfólio, seleção dos } \\
\text { métodos a serem utilizados. } \\
\text { Desenvolvimento do foco e da } \\
\text { orientação estratégica, } \\
\text { levantamento de restrições nos } \\
\text { recursos, escolha de modelos e } \\
\text { técnicas. }\end{array}$ & $\begin{array}{l}\text { Mapeamentos estratégicos, } \\
\text { matrizes de portfólios, análise } \\
\text { de clusters etc. }\end{array}$ & \\
\hline \multirow[t]{5}{*}{$\begin{array}{l}\text { Processo de } \\
\text { seleção de } \\
\text { projetos }\end{array}$} & Pré-avaliação & $\begin{array}{c}\text { Rejeição de projetos que não } \\
\text { estejam alinhados com a } \\
\text { orientação estratégica }\end{array}$ & $\begin{array}{l}\text { Foco estratégico, estudo de } \\
\text { viabilidade, experiência dos } \\
\text { analistas. }\end{array}$ \\
\hline & Análise de cada projeto isolado & $\begin{array}{l}\text { Cálculo de parâmetros comuns } \\
\text { para cada um dos projetos }\end{array}$ & $\begin{array}{c}\text { Árvores de decisão, } \\
\text { estimativas de risco, VPL, } \\
\text { ROI, exigência de recursos } \\
\text { etc. }\end{array}$ \\
\hline & Análise de sinergias & $\begin{array}{l}\text { Rejeição de projetos inviáveis } \\
\text { tecnicamente, comercialmente, } \\
\text { financeiramente etc. }\end{array}$ & $\begin{array}{c}\text { Técnicas } A d-h o c \text { (perfis de } \\
\text { projetos, famílias, } \\
\text { plataformas etc) }\end{array}$ \\
\hline & Seleção do portfólio "ótimo" & $\begin{array}{c}\text { Otimização geralmente baseada } \\
\text { em algum modelo ou } \\
\text { ferramenta computacional. } \\
\text { Considerações integradas dos } \\
\text { projetos atributos de cada } \\
\text { projeto, restrições de recursos, } \\
\text { sinergias e interações entre os } \\
\text { projetos. }\end{array}$ & $\begin{array}{c}\text { AHP, opções reais, } \\
\text { pontuação, análise de } \\
\text { sensibilidade, análises } \\
\text { marginal. }\end{array}$ \\
\hline & Ajustes finais no portfólio & $\begin{array}{c}\text { Alterações “manuais” após a } \\
\text { otimização do portfólio }\end{array}$ & $\begin{array}{l}\text { Matrizes de projetos, } \\
\text { análise de sensibilidade. }\end{array}$ \\
\hline Pós-processos & Portfólio final & Desenvolvimento dos projetos & $\begin{array}{c}\text { Técnicas de gerenciamento } \\
\text { de projetos (PMI, SEI etc), } \\
\text { coleta de dados, indicadores } \\
\text { dos projetos. }\end{array}$ \\
\hline
\end{tabular}

Quadro 5 - Possíveis atividades e métodos do processo de seleção de projetos do portfólio Fonte: adaptado de Archer e Ghasemzadeh (1999), p. 213.

\subsubsection{Modelo de Cooper}

O modelo proposto por Cooper (1994) para o desenvolvimento de produtos tem sido largamente utilizando também para auxiliar na gestão do portfólio, pois divide o processo decisório em etapas bem definidas e auxilia os gestores na seleção e priorização dos projetos. Cooper et al. (2001) adicionam aos conceitos de gerenciamento do portfólio questões sobre a dinâmica do processo, enfatizando que a GPPNP é um processo dinâmico onde os projetos são constantemente alterados e revisados. Para eles são três os principais objetivos do gerenciamento do portfólio: maximização de valor, balanceamento entre os projetos e alinhamento estratégico. Ainda segundo Cooper et al. (1997), a ausência da gestão do 
portfólio de projetos de novos produtos na organização tem efeitos negativos de curto e longo prazo, como se pode ver pela figura seguinte:

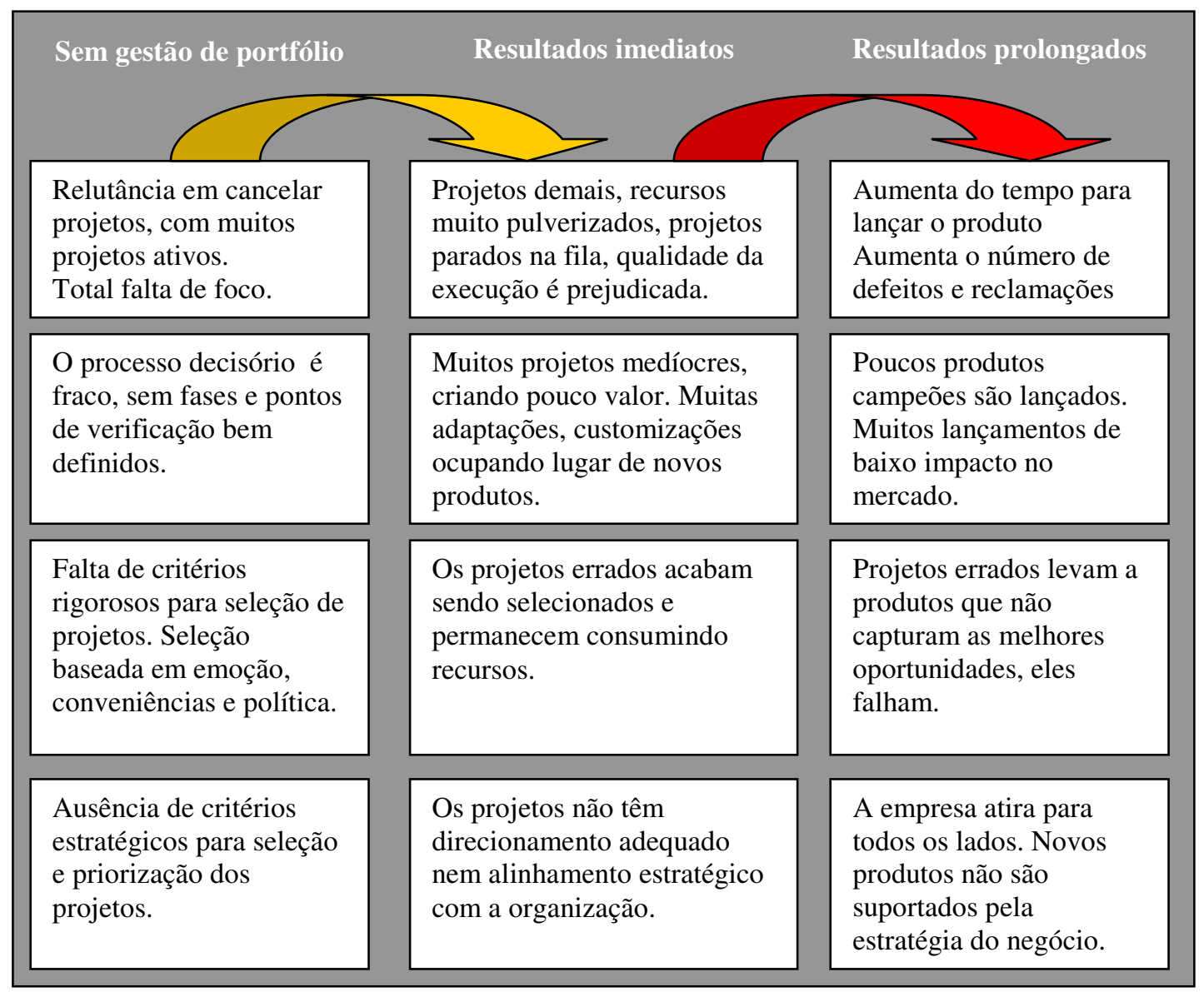

Figura 9 - Impactos da ausência de gestão do portfólio de projetos

Fonte: adaptado de Cooper et al. (1997), p. 3.

Os primeiros modelos de seleção de projetos originados nas décadas de 60 e 70 eram altamente matemáticos, empregando técnicas como programação linear e dinâmica. O seu objetivo era otimizar o portfólio de projetos, maximizando alguma função de objetivo (por exemplo, os lucros esperados) sujeita a certas restrições de recursos. Qualquer um que seja familiar com esse tipo de modelo reconhece a dificuldade matemática para resolver tais problemas. Apesar de serem conceitualmente atraentes e bastante rigorosos, os modelos matemáticos para gestão do portfólio aparecem mais nos artigos e livros acadêmicos que nos escritórios de projeto da empresas (COOPER et al., 1997, 1999; ARCHER; GHASEMZADEH, 1999).

Estudos realizados por Cooper et al. (1999) em empresas dos EUA e Europa mostraram que os executivos têm grande aversão por esses modelos matemáticos, e por uma 
boa razão. O principal obstáculo é a grande quantidade de dados necessários: acompanhamento financeiro, progresso temporal das atividades, alocação de recursos humanos, probabilidades de sucesso dos projetos, dentre outras. Uma boa parte dessas informações simplesmente não é disponível e mesmo quando o é, deve-se suspeitar da sua confiabilidade. Veja na figura seguinte as principais abordagens usadas para gestão do portfólio de novos produtos:

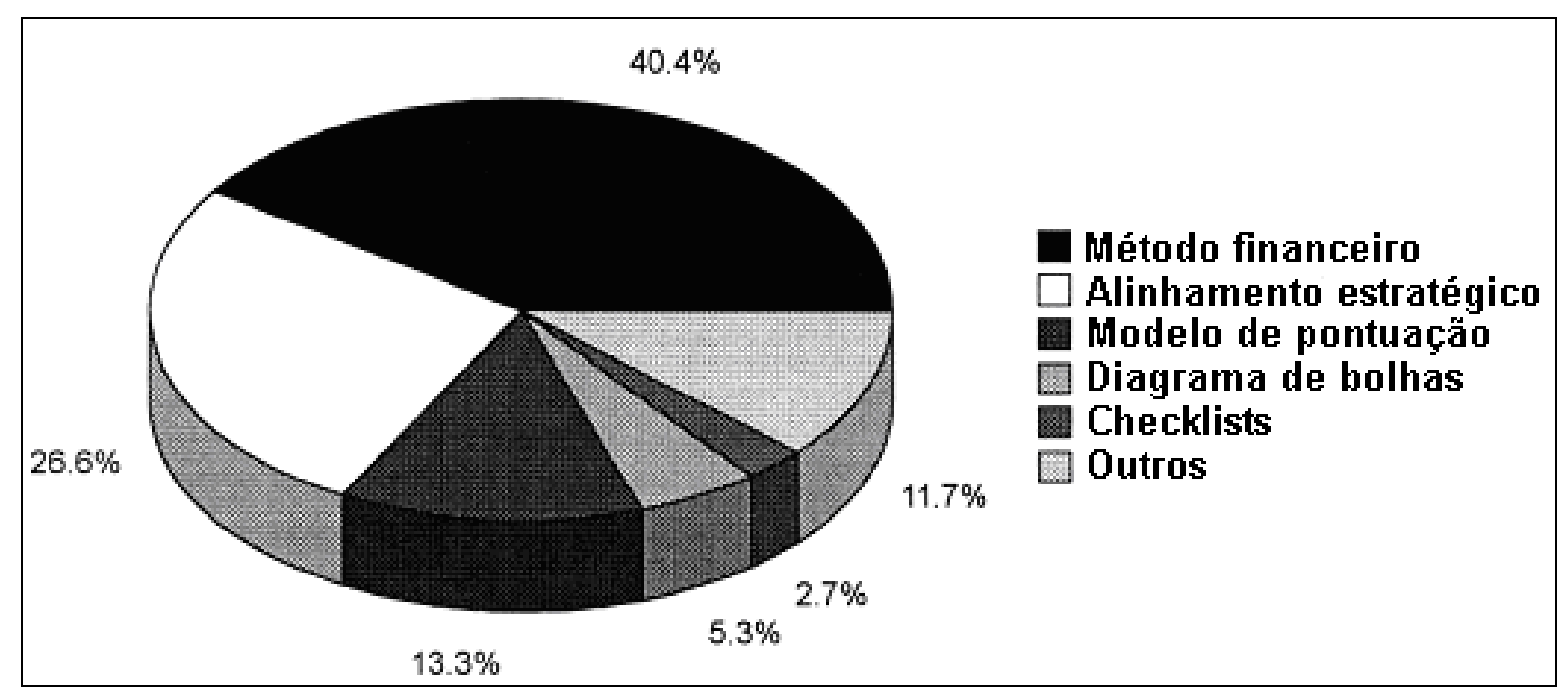

Figura 10 - Principais abordagens usadas na gestão do portfólio de novos produtos Fonte: adaptado de Cooper et al. (1999), p. 347.

Com o objetivo de melhorar o desempenho da GPPNP nas empresas, o processo de gestão da inovação chamado Stage-Gate ${ }^{\mathrm{TM}}$ pode ser aplicado do ponto de vista da gestão do portfólio de projetos de novos produtos. Esse processo consiste em uma série de estágios e portões (pontos de verificação), que separam o caminho entre uma idéia e o lançamento de um produto no mercado. No Stage-Gate ${ }^{\mathrm{TM}}$ nenhuma fase é executada por uma função isolada na empresa. Por exemplo, a fase de desenvolvimento não é executada apenas pelo departamento de P\&D. São equipes multifuncionais, formadas por pessoas de marketing, $\mathrm{P} \& \mathrm{D}$, manufatura, marketing, finanças e outras áreas que formam os times de projetos. As decisões e revisões são em equipe, demandando um esforço considerável de análise do negócio e do mercado, em conjunto com uma completa avaliação sobre a fabricação do produto, antes mesmo que seja aprovado seu desenvolvimento. O processo baseia-se em oito premissas (COOPER, 1994; COOPER et al, 1997):

1. O processo de novos produtos deve ser um processo de qualidade, sistemático, da idéia ao lançamento do produto. 
2. Deve ser concebido para gerenciar os riscos. Assim, uma estrutura de múltiplos estágios e pontos de decisão é a mais apropriada.

3. Pontos de decisão (portões) são fundamentais no processo, pois fornecem um mecanismo de controle de qualidade, com critérios bem definidos para aprovar ou abortar os projetos em cada uma das fases.

4. Processamento em paralelo equilibra a necessidade entre um processo completo de qualidade e o desejo de um processo mais veloz. Isso é obtido ao integrar diversas funções da empresa em uma mesma fase do processo.

5. O processo requer uma equipe interdepartamental, liderada por uma pessoa experiente e com autoridade adequada.

6. O processo é orientado ao mercado, com foco no cliente.

7. Reunir informações confiáveis na fase de pré-desenvolvimento é crucial ao sucesso e essa atividade deve ser executada de forma consistente e sistemática.

8. Deve se concentrar na busca por produtos diferenciados que agreguem valor ao usuário.

O modelo divide o desenvolvimento do produto em estágios pré-determinados, sendo que cada estágio consiste de um conjunto de atividades pré-definidas, multifuncionais e paralelas. A entrada para cada estágio é um ponto de decisão (portão): estes pontos controlam o processo, a qualidade do projeto e a tomada de decisão. Os diversos estágios e portões do modelo podem ser vistos na figura seguinte:

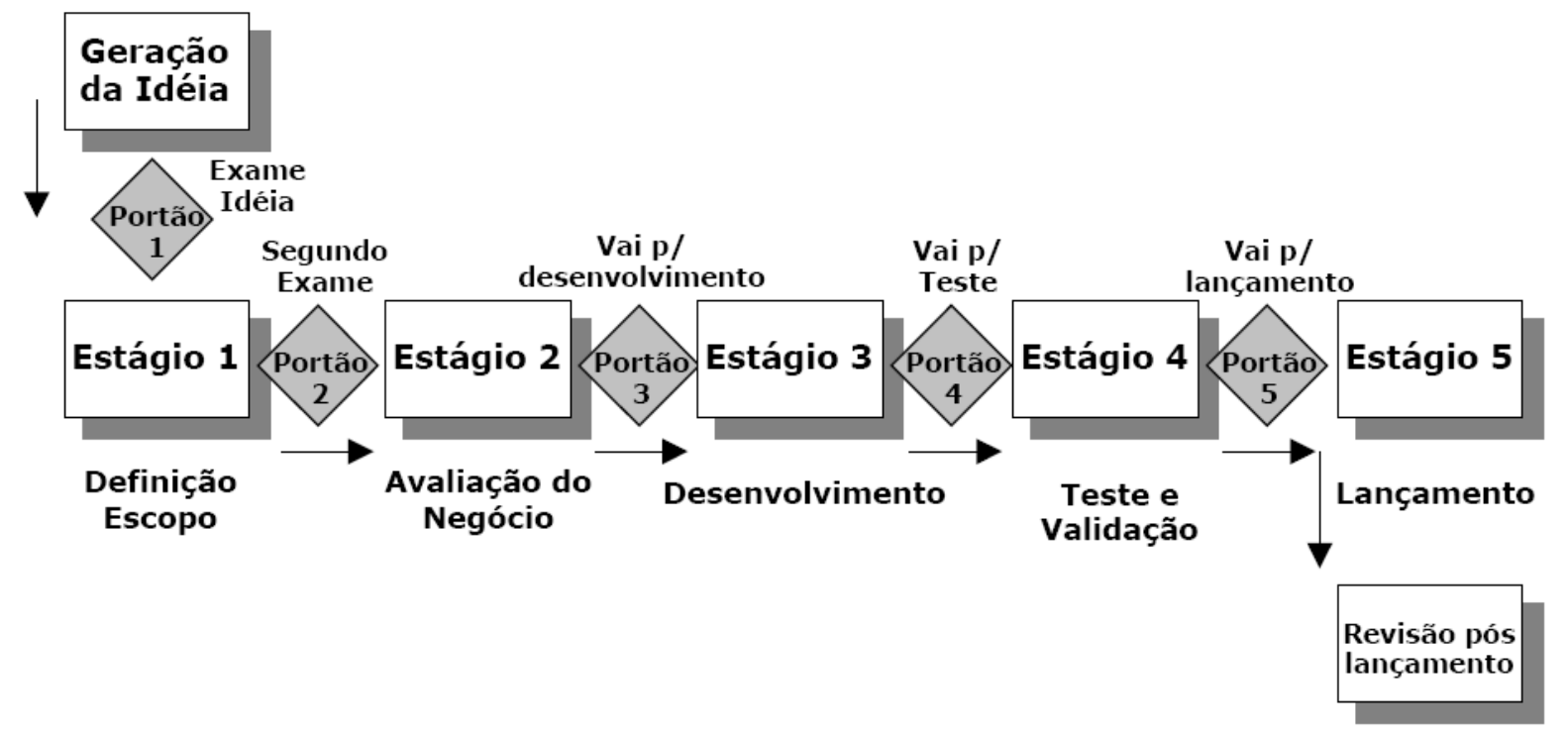

Figura 11 - Diagrama geral do modelo Stage-Gate

Fonte: adaptado de Cooper (1994), p. 5. 
Além das sete fases inerentes ao modelo, as investigações de Cooper et al. (1997) sobre gestão do portfólio de novos produtos revelaram 14 questões primordiais que devem ser respondidas para desenvolver as melhores práticas de gestão. Essas questões são as seguintes:

1. Qual é o principal objetivo do modelo de gestão do portfólio da empresa?

2. O modelo permite maximizar o valor do portfólio de acordo com algum objetivo específico?

3. O modelo permite atingir o equilíbrio correto entre os projetos?

4. O modelo está firmemente conectado à estratégia do negócio?

5. Como são integradas as decisões nas etapas de cada projeto com as decisões do portfólio?

6. O modelo é consistente com a qualidade das informações disponíveis?

7. Quão firme é o comprometimento dos recursos uma vez que o projeto seja incluído no portfólio?

8. Como são administrados projetos que são interrompidos temporariamente?

9. É realmente necessário ter uma lista priorizada de projetos, ou um ranking dos projetos?

10. Que tipos de projetos são considerados no modelo de seleção? Os projetos são todos comparados entre si ou apenas são comparados com projetos de mesmo tipo?

11. Qual é o papel esperado do modelo de gestão do portfólio: facilitar o processo, mostrar informações aos gestores ou ser um modelo para tomara de decisão automática?

12. Como se evita a sobrecarga de informações durante a análise dos projetos?

13. Como as informações necessárias são coletadas e apresentadas?

14. Como são tratados os problemas criados pela análise financeira, tais como fluxos de caixa não-confiáveis, incerteza nas informações apresentadas, canibalismo entre produtos etc?

\subsubsection{Modelo do Project Management Institute (PMI)}

O modelo de gestão do portfólio de projetos do PMI (2006b) é o mais complexo dentre os modelos teóricos de referencia. A gestão do portfólio de projetos constitui um processo formado hierarquicamente por sub-processos constituintes, cujas atividades representam as melhores práticas coletadas e aceitas em diversos segmentos da indústria. Segundo o PMI (2006b), um portfólio é uma coleção de projetos, programas e outras 
atividades que são agrupados para facilitar a gestão efetiva do esforço para atingir os objetivos estratégicos do negócio. Os projetos, programas e outras atividades relacionadas são chamados de componentes do portfólio. Os componentes do portfólio são quantificáveis, isto é, eles podem ser medidos, ordenados e priorizados. Os componentes do portfólio podem não ser necessariamente interdependentes ou estarem diretamente relacionados. Em um dado momento no tempo, o portfólio representa uma amostra de seus componentes que reflete e afeta os objetivos estratégicos da organização. Em outras palavras, o portfólio representa o conjunto de projetos, programas e outras atividades da organização, em um dado momento no tempo.

É importante entender a relação entre o portfólio e seus componentes. Um portfólio reflete os investimentos realizados ou planejados por uma organização, que estão alinhados com os seus objetivos estratégicos. No portfólio as prioridades são identificadas, decisões de investimento são tomadas e recursos são alocados. Efetivamente, os investimentos são a realização da estratégia da empresa. Se alguém quiser saber qual e o plano estratégico de uma organização, olhe para onde estão indo os recursos. Não é raro que o planejamento estratégico fique engavetado e que as decisões de investimento não reflitam totalmente o que foi planejado (PMI, 2006b).

Se determinados componentes do portfólio (projetos e/ou programas) não estão alinhados com a estratégia organizacional, alguém pode questionar, com razão, porque esses componentes estão sendo empreendidos. Para auxiliar nessa tarefa, o PMI (2006b) define quatro atributos básicos para identificar os componentes do portfólio, e afirma que todos os componentes de um portfólio exibem certas características comuns:

a. Representam investimentos realizados ou planejados pela organização.

b. São alinhados com os objetivos e intenções estratégicas da empresa.

c. Tipicamente eles possuem algumas características que ao mesmo tempo os diferenciam e permite que a organização os agrupe para uma gestão mais efetiva.

d. Os componentes de um portfólio são quantificáveis, isto é, eles podem ser medidos, ordenados e priorizados.

A gestão do portfólio também é um processo que engaja e auxilia os executivos a atingirem as necessidades e expectativas da organização. A gestão do portfólio acentua a transparência e melhora o processo decisório com relação aos projetos, sendo conduzida em um ambiente mais amplo que o portfólio em si, por meio de seus processos e atores que permeiam toda a organização (PMI, 2006b). 
A gestão do portfólio pode ser vista como uma abordagem gerencial para atingir objetivos estratégicos por meio da seleção, priorização, avaliação e gerenciamento de projetos, programas ou outras atividades baseadas em seu alinhamento e contribuição para as estratégias e objetivos da organização. A gestão do portfólio combina: (a) o foco da organização em garantir que os projetos selecionados para investimento atinjam a estratégia do portfólio e (b) o foco do gerenciamento de projetos em efetivamente entregar projetos cuja contribuição esteja dentro do planejado (PMI, 2006b).

A gestão do portfólio é um processo de negócio contínuo, com certas atividades que acontecem durante um período determinado pela organização, geralmente um ano. Seleção e autorização, por exemplo, pode ser parte do planejamento anual, ou atualizações estratégicas trimestrais ou semestrais. Já o monitoramento da performance do portfólio, usualmente, é um processo continuo, mensal ou mesmo semanal. A revisão do mix de projetos pode ser necessária quando a organização sofre alterações importantes. Uma vez estabelecido, o processo de gestão do portfólio não tem fim, exceto se a organização escolher abandonar essa abordagem ou encerrar suas atividades (PMI, 2006b).

Os processos de gestão do portfólio incluem a coleta, identificação, categorização, avaliação, seleção, priorização, balanceamento, autorização e revisão dos componentes do portfólio, para avaliar quão bem eles estão se desenvolvendo, frente a indicadores dos projetos e ao plano estratégico. Durante um ciclo de negócio típico, os componentes (projetos) são revisados e validados em relação aos seguintes elementos (PMI, 2006b):

a. Alinhamento dos componentes com a estratégia corporativa.

b. Viabilidade dos componentes como parte do portfólio, baseada em indicadores.

c. Valor e relação entre os componentes.

d. Disponibilidade de recursos e prioridades do portfólio.

e. Adição e exclusão de componentes do portfólio.

$\mathrm{O}$ adequado balanceamento dos projetos, observando o alinhamento com os objetivos estratégicos da empresa, tanto no curto como no longo prazo, é a essência da gestão do portfólio. As decisões precisam ser tomadas no melhor interesse da performance global do portfólio, independentemente do impacto individual para os componentes (PMI, 2006b).

A organização como um todo deve entender a necessidade da gestão do portfólio para o negócio e comprometer pessoas, processos e ferramentas para torná-lo um sucesso. A falta de suporte organizacional para o conceito e a abordagem da gestão do portfólio é um grande obstáculo ao sucesso dessa alternativa gerencial, sucesso esse que é diretamente afetado pelo nível de maturidade da organização. Outro importante elemento é a habilidade da organização 
em aceitar e implementar as mudanças oriundas da gestão do portfólio. O maior obstáculo para atingir um alto nível de melhoria esperada da gestão do portfólio é o não reconhecimento e a não formalização de como a empresa lida com as mudanças. Cada componente do portfólio deve aplicar consistentemente técnicas similares para facilitar e lidar com as mudanças organizacionais (PMI, 2006b).

O PMI (2006b) sugere alguns processos para a gestão do portfólio, os quais contemplam as práticas mais aceitas em uma ampla gama de indústrias, para a maioria dos portfólio de projetos. Entenda-se por práticas mais aceitas, aquelas onde há um consenso geral de que a aplicação desses processos na gestão do portfólio de projetos aumenta a probabilidade de sucesso com o passar do tempo. Contudo, isso não significa que todos os processos descritos devem ser sempre aplicados integralmente e da mesma forma para todos os portfólios. O time de gestão do portfólio é sempre responsável por determinar que processo é apropriado e qual o grau de rigor a ser usado para cada processo, de acordo com o portfólio em questão. O PMI (2006b) assume que, para implementar a gestão do portfólio, as seguintes condições devem existir na organização:

a. A organização, incluindo alta direção e gerentes, aceita a teoria de gestão do portfólio.

b. Existe um certo número de projetos a serem avaliados ou já em andamento na organização.

c. Pessoas treinadas estão disponíveis para executar as atividades de gestão do portfólio.

d. Existe um processo formal estabelecido para o gerenciamento de projetos.

e. Os papéis e responsabilidades dentro da organização estão definidos.

f. Um plano de comunicação foi desenvolvido para comunicar as decisões estratégicas por toda a organização.

O PMI (2006b) descreve os processo de gestão do portfólio em termos de sua integração, de suas interações e dos objetivos de cada processo. Esses processos constituem dois grupos, conhecidos como grupos de processos da gestão do portfólio:

a. Grupo de processos de alinhamento: este grupo determina como os componentes serão categorizados, avaliados e selecionados para inclusão e gestão por meio do portfólio.

b. Grupo de processos de controle de monitoração: este grupo revisa periodicamente os indicadores de performance para verificar o alinhamento aos objetivos estratégicos.

Esses grupos têm dependências claras e são executados na gestão de cada portfólio. Eles são independentes da área de aplicação ou do foco da indústria. Grupos e seus processos constituintes interagem freqüentemente durante o processo. $\mathrm{O}$ grupo de processos de 
alinhamento depende de sub-processos da fase de planejamento e autorização. De forma análoga, o grupo de processos de controle e monitoração está relacionado aos sub-processos das fases de monitoração e controle na empresa (PMI, 2006b). Isso reforça a idéia de que a gestão do portfólio, na prática, não é um processo isolado, mas sim, que depende fortemente dos processos executados ao longo de todo o ciclo de negócios, ou seja, como parte da gestão da inovação, também é um processo interdepartamental (KRUGLIANSKAS et al., 2006).

O grupo de processos de alinhamento garante a disponibilidade de informações atualizadas com relação aos objetivos estratégicos do negócio, os quais devem ser suportados pelo portfólio, bem como as regras operacionais vigentes para avaliação e gestão dos componentes do portfólio. Além disso, esse grupo de processos estabelece uma estrutura baseada em consenso para manter o mix de projetos alinhado à estratégia organizacional. $\mathrm{O}$ grupo de processos de alinhamento é mais ativo nos períodos em que a organização atualiza seus objetivos estratégicos e propõe orçamentos e planos de curto e médio prazo. Tradicionalmente, essas atividades acontecem durante o planejamento do orçamento anual. Contudo, algumas organizações trabalham com ciclos de atualização mais freqüentes. Tais atividades podem ser programadas trimestralmente, por exemplo, ou podem ocorrer devido a alterações no clima do negócio (PMI, 2006b).

O grupo de processos de controle e monitoração, por sua vez, se concentra nas atividades necessárias para garantir que o portfólio como um todo tenha performance aceitável, de acordo com métricas pré-definidas e determinadas pela organização. Essas métricas, por exemplo, ROIC, NPV, podem ser monitoradas por categoria e performance agregada. Em alguns casos, componentes individuais do portfólio podem também monitorados.

Os processos listados a seguir são considerados pelo PMI como sendo as melhores práticas na gestão do portfólio de projetos, independentemente do setor da empresa. Cada processo possui características peculiares, descritas a seguir (PMI, 2006b):

1. Planejamento estratégico: planos estratégicos são usados por uma empresa para alinhar sua estrutura e seu orçamento com as prioridades, missão e objetivos do negócio. Um plano estratégico tipicamente inclui uma visão e uma declaração de missão, uma descrição dos objetivos e metas de longo prazo e dos meios pelos quais a empresa planeja atingir esses resultados. O plano estratégico pode também identificar fatores externos que podem interferir na obtenção dos resultados de longo prazo desejados. O planejamento estratégico é o processo usado pela organização para antecipar e reagir às mudanças esperadas. Planos operacionais são desenvolvidos pela 
gerência para suportar as operações da empresa. Esses planos podem estar fortemente acoplados ao planejamento estratégico, ou não.

2. Identificação: a função desse processo é criar uma lista atualizada, com informações suficientes, de todos os componentes novos e em andamento que serão gerenciados por meio do processo de GPPNP. As atividades primordiais desse processo incluem:

- Comparação entre os projetos em andamento e os novos projetos, usando definições e critérios pré-determinados.

○ Rejeição de projetos que não estejam alinhados com os critérios definidos.

- Classificação dos projetos de acordo com categorias pré-definidas.

3. Categorização: o propósito desse processo é identificar projetos em categorias relevantes para o negócio, nas quais um conjunto comum de filtros e critérios de decisão pode ser aplicado para avaliação, seleção, priorização e balanceamento. As categorias são definidas de acordo com o planejamento estratégico para novos produtos e novas tecnologias. Os componentes em um dado grupo têm objetivos comuns e podem ser comparadas com as mesmas informações. A categorização permite à empresa equilibrar os riscos e investimentos entre as diversas categorias e objetivos estratégicos. Atividades comuns a esse processo:

- Identificar os objetivos estratégicos a partir do planejamento estratégico da empresa.

- Comparar os projetos usando os critérios obtidos a partir dos objetivos estratégicos identificados

- Agrupar os projetos da mesma categoria.

4. Avaliação: esse processo cuida de reunir todas as informações necessárias e disponíveis para comparar as propostas de projetos, de forma a facilitar o processo de seleção. A informação pode ser qualitativa ou quantitativa e pode vir de diversas fontes. Essas diversas fontes devem ser questionadas até que se obtenha o nível de informação desejado para suportar o processo seguinte, de seleção dos projetos. AS atividades principais desse processo são:

- Avaliar os projetos usando modelos de pontuação, baseados em critérios com diferentes pesos.

- Produzir gráficos e diagramas que facilitem a tomada de decisão no processo de seleção dos projetos.

○ Tecer recomendações relevantes com relação a cada projeto avaliado. 
5. Seleção: esse processo é responsável por produzir uma lista de projetos baseada nas recomendações do processo anterior, de avaliação, e também nos demais critérios definidos pela empresa. A seleção, em conjunto com as informações vindas do processo de avaliação, produz uma lista de projetos que deve ser priorizada. As atividades típicas desse processo incluem a seleção e comparação entre os projetos, produzindo uma lista para o próximo processo, de priorização.

6. Priorização: esse processo deve produzir uma lista priorizada (ordenada) de projetos para cada categoria estratégica ou orçamentária (por exemplo, redução de custos, crescimento, manutenção da participação no mercado ou inovação). Ele também deve levar em conta outros atributos, como: horizonte de tempo (curto, médio e longo prazos), perfil de risco x retorno, e outros critérios que os gestores do portfólio julgarem importantes para as próximas fases do processo. AS atividades principais desse processo são:

- Confirmar a classificação dos projetos de acordo com categorias estratégias pré-determinadas.

○ Determinar uma pontuação ou um peso para cada critério analisado.

- Listar os projetos por ordem de prioridade.

7. Balanceamento: esse processo procura determinar, dentre os projetos já selecionados e priorizados, a combinação de projetos que apresente o maior potencial e que coletivamente suporte os objetivos estratégicos da empresa. Essa combinação equilibrada de projetos também inclui os projetos já em andamento. O balanceamento, ou equilíbrio entre os projetos, permite à organização atingir um dos principais benefícios da GPPNP: planejar e alocar adequadamente os recursos (financeiros, físicos e humanos) de forma alinhada aos objetivos estratégicos da empresa, além de maximizar o retorno do portfólio. O equilíbrio entre os projetos é obtido por meio da análise do risco tolerado pela organização, pelas métricas de performance definidas para o portfólio e pelas restrições nos recursos disponíveis. A seleção do melhor mix de componentes também deve levar em conta as sinergias entre os projetos, que incluem as dependências e interconexões que possam existir. Como saída do processo obtém-se uma lista com a melhor combinação de projetos. Suas atividades incluem:

- Adicionar novos projetos ao portfólio atual da empresa.

- Identificar, dentre os novos projetos selecionados, aqueles que não são interessantes no momento.

- Cancelar, suspender ou repriorizar projetos em andamento. 
8. Autorização: aqui, a idéia é formalmente alocar recursos para os projetos indicados pelas fases anteriores. Essa fase também marca a comunicação das decisões tomadas pelos gestores do portfólio para toda a empresa. Atividades relacionadas:

- Comunicar as decisões tomadas com relação ao portfólio de projetos de novos produtos a todos os interessados.

- Autorizar o início de novos projetos, finalizar, suspender ou cancelar outros.

- Realocar recursos orçamentários de projetos terminados ou suspensos.

- Alocar recursos orçamentários e humanos para executar os novos projetos.

- Comunicar os resultados esperados do novo portfólio, em termos agregados e para cada projeto.

9. Revisão e acompanhamento: esse processo cuida de reunir informações e indicadores de performance para acompanhamento e revisões do portfólio de projetos. A freqüência depende da dinâmica de cada organização, mas deve garantir tanto o alinhamento estratégico quando a eficiente utilização dos recursos. O propósito das revisões é garantir que o portfólio contenha apenas projetos que contribuam efetivamente para atingir os objetivos da empresa. $\mathrm{Na}$ prática, isso significa periodicamente adicionar novos projetos, repriorizar ou excluir outros já em execução.

10. Mudança estratégica: esse processo confere à organização a habilidade de responder às mudanças estratégicas. Pequenas mudanças no planejamento estratégico freqüentemente não demandam mudanças no portfólio de projetos. Entretanto, caso as mudanças impliquem em alterações no portfólio de projetos, pode ser necessário reclassificar e repriorizar projetos, exigindo também um novo balanceamento.

11. Execução e acompanhamento: esse processo complementa o processo de revisão e acompanhamento fornecendo informações sobre os componentes do portfólio.

A figura seguinte ilustra todo o processo sugerido pelo PMI (2006b): 


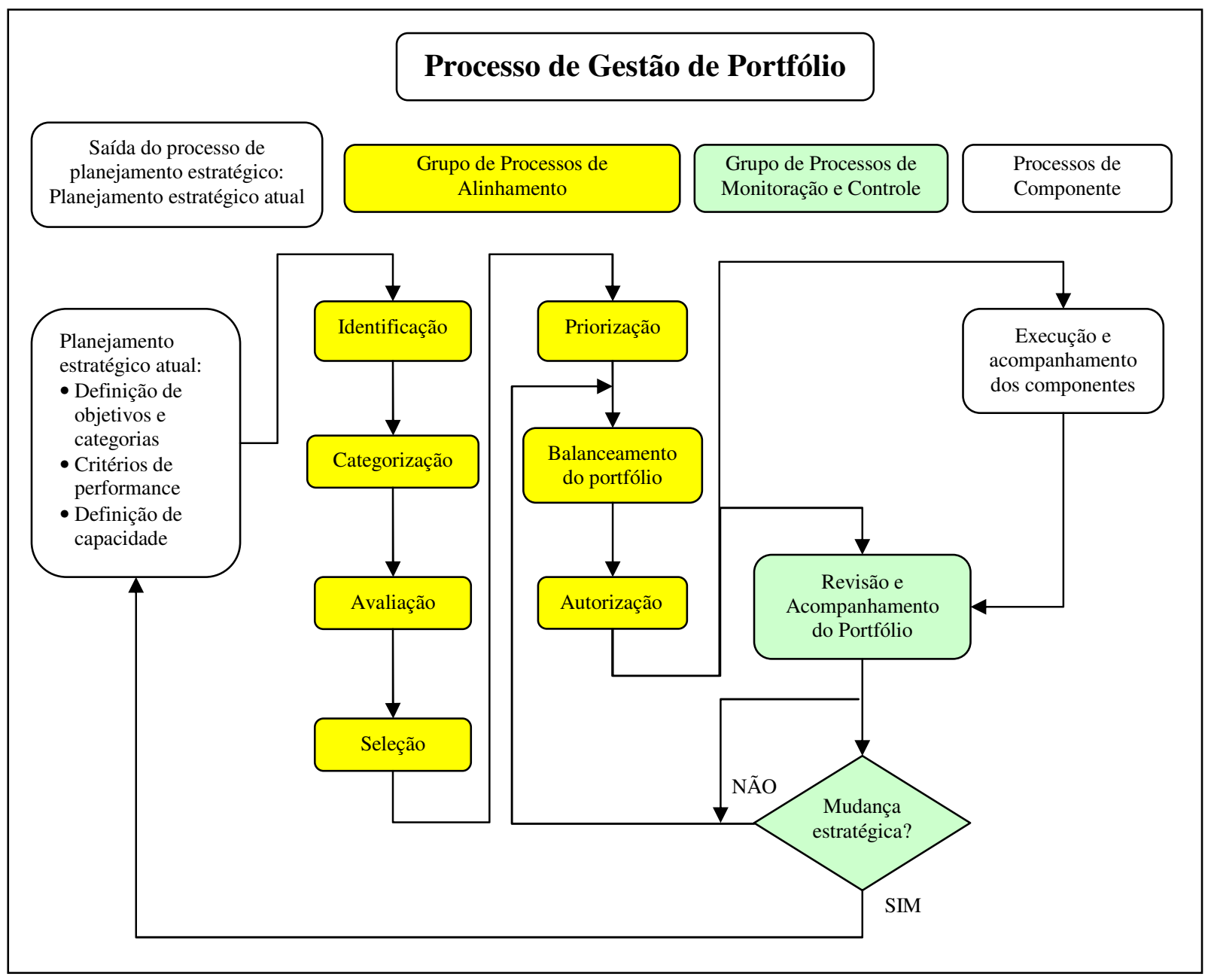

Figura 12 - Processos da gestão do portfólio de projetos segundo o PMI

Fonte: adaptado de PMI (2006b), p. 25.

\subsubsection{Sinergia e dependência entre os projetos do portfólio}

A literatura pesquisada oferece poucas abordagens objetivas sobre a determinação da sinergia entre os projetos e como essa sinergia pode ser considerada no problema da avaliação e seleção dos projetos para composição do portfólio. Em um recente estudo sobre novos produtos farmacêuticos, Blau et al. (2004) tecem algumas considerações sobre a quantificação da sinergia entre projetos. Indústrias altamente regulamentadas, como as indústrias farmacêutica e agro-química, enfrentam o desafio de manter um fluxo contínuo de novos produtos. Essa tarefa se mostra árdua devido às baixas taxas de sucesso técnico, altos custos de desenvolvimento, impacto incerto no mercado, carência de boas idéias para novos produtos e especialmente a limitação de recursos humanos e financeiros para desenvolver esses novos produtos. 
Os problemas da avaliação, seleção e sequenciamento (priorização) de novos projetos, se tornam ainda mais complicados devido à presença de dependências e inter-relações entre os produtos, tanto no âmbito do mercado quando do próprio processo de desenvolvimento. Blau et al. (2004) propõe um modelo para seleção e sequenciamento de projetos que maximiza o retorno econômico, dado um determinado risco tolerável pela organização e um determinado conjunto de recursos disponíveis. Uma rede probabilística é usada para capturar todas as atividades e recursos demandados pelo processo de desenvolver um novo medicamento. $\mathrm{O}$ modelo é composto basicamente das seguintes fases:

a. Um esquema de priorização usando diagrama de bolhas convencional gera uma lista preliminar que leva em conta recursos ilimitados e independências entre os projetos.

b. Essa lista inicial é usada para inicializar um algoritmo genético de busca que sugere uma seqüência ótima, já considerando recursos limitados e interdependência entre os projetos.

c. Essas seqüências geradas pelo algoritmo genético permitem a criação de uma fronteira de risco-retorno, com a qual escolhe-se o portfólio ótimo.

A metodologia é ilustrada por meio de um estudo de caso com dados reais de uma indústria farmacêutica, envolvendo nove projetos interdependentes. O resultado da otimização do portfólio pelo algoritmo genético sugere um retorno $28 \%$ maior que o portfólio inicial criado usado apenas o digrama de bolhas (BLAU et al., 2004).

Ainda segundo Blau et al. (2004), o retorno individual dos produtos freqüentemente é influenciado por outros produtos no portfólio e por produtos de competidores. Em alguns casos pode ser até mesmo vantajoso priorizar o desenvolvimento de um novo produto apesar da baixa atratividade financeira e baixa probabilidade técnica de sucesso para promover a criação de uma base de conhecimento que pode catalisar o sucesso de novos produtos que venham a ser desenvolvidos posteriormente. Dentre as possíveis dependências entre os produtos, quatro tipos mais freqüentes são considerados: (a) recursos, compartilhados, (b) custos de fabricação, (c) retorno financeiro e (d) probabilidade de sucesso técnico. A curva de aprendizado também leva freqüentemente à dependência ente projetos. Um exemplo comum citado pelos autores ocorre quando o tempo de desenvolvimento é reduzido para um tipo de droga que pode ser usada em mais de um tipo de medicamento, de forma análoga a uma plataforma para o desenvolvimento de novos produtos derivados (UTTERBACK, 1996; CLARK; FUJIMOTO, 1991).

Dependências de custo ocorrem quando o custo combinado de uma atividade de desenvolvimento para duas drogas candidatas é menor que a soma dos custos individuais de 
desenvolvimento, especialmente devido ao compartilhamento de recursos. Por exemplo, é possível que dois produtos similares usem a mesma fábrica para serem produzidos. A dependência em termos de retorno financeiro ocorre quando há sinergia ou antagonismo na aplicação final, ou pelo menos essa condição é percebida pelo mercado. Por exemplo, o efeito de canibalização que pode ocorrer quando dois produtos que competem entre si são lançados sem levar em conta o planejamento adequado do ciclo de vida do produto. Por outro lado, vários projetos podem se complementar mutuamente de forma a promover o incremento de vendas um do outro (BLAU et al., 2004).

Dependências técnicas ocorrem quando a probabilidade de sucesso técnico de um produto afeta a probabilidade de outros produtos. Por exemplo, duas novas drogas podem ser desenvolvidas para liberar um componente ativo de forma controlada. Se a primeira droga obtiver sucesso, a probabilidade de sucesso da segunda, mesmo que sem ter sido testada, será maior (BLAU et al., 2004).

\subsubsection{Considerações sobre a alocação de recursos entre os múltiplos projetos}

A maioria das iniciativas para o desenvolvimento de novos produtos sofre de sérias deficiências de recursos ao longo de todas as funções do negócio, e muitos dos sintomas que corroem o processo de desenvolvimento de produtos como um todo, podem ser ligados diretamente a essa deficiência de recursos, ou pelo menos, à deficiência na alocação desses recursos (COOPER; EDGETT, 2003; HENDRIKS et al., 1999).

As raízes das causas desse problema são a excessiva preocupação com a performance financeira de curto-prazo, a relutância em abandonar projetos (e a resultante perda de foco) e a desejo de uma excessiva velocidade em colocar o produto no mercado. As soluções estratégicas para esses problemas incluem o alinhamento dos recursos com os objetivos do negócio, reconhecendo que nem todos os negócios podem ser medidos com a mesma régua e nem os recursos alocados da mesma maneira. Uma das saídas para minimizar esses problemas é adotar a GPPNP como alternativa gerencial (COOPER; EDGETT, 2003).

A gestão do portfólio permite um maior foco (menos projetos com maior criação de valor), e também permite que os projetos seja alinhados com as estratégias da empresa para atingir o correto balanceamento entre os investimentos nos projetos. Finalmente, soluções táticas incluem o acompanhamento da alocação dos recursos existentes por meio de análises 
de capacidade de recursos e do mapeamento mais preciso dos recursos necessários como parte do processo de tomada de decisão em cada fase do processo (COOPER; EDGETT, 2003).

Diferentemente de recursos financeiros em investimentos bancários, pessoas não podem ser imediatamente transferidas de um projeto para outro sem turbulências. A alocação de recursos humanos é um dos processos mais fundamentais da gestão de múltiplos projetos. É como em um jogo de xadrez: cada profissional envolvido deve possuir habilidades complementares, assim como cada peça pode executar um tipo de movimento que completa os demais. Deve haver alguma redundância para que na ausência de um dos envolvidos no projeto, outro possa assumir suas atividades mesmo que temporariamente. Além disso, a redundância permite que certas atividades possam ser executadas em paralelo. O time deve ter objetivos claros e compartilhados (COOPER et al., 1997).

Cooper e Edgett (2003) afirmam que, além das já conhecidas desculpas da falta de informação de mercado, das falhas ao ouvir os clientes, das deficiências na fase de préprojeto, da instabilidade de requisitos e definições do produto, da baixa qualidade na execução de tarefas do processo e dos times mal estruturados e ineficientes, a insuficiência de recursos em diversas funções organizacionais é a principal causa de insucesso nos projetos de desenvolvimento de novos produtos. Em um dos estudos desses autores, um líder sênior de projeto declarou: "Não decidimos deliberadamente por realizar um trabalho ruim nos projetos. Mas com sete grandes projetos em andamento, além do dia a dia já ocupado, estou sendo obrigado a falhar. Simplesmente não há tempo para garantir que esses projetos sejam executados da maneira como devem ser". Os autores identificaram seis problemas decorrentes da insuficiência de recursos:

a. Baixa qualidade na execução.

b. Atividades vitais não são executadas.

c. Maior tempo para lançar o produto.

d. Oportunidades são perdidas.

e. Produtos perdem funcionalidade.

f. Baixa moral do time de desenvolvimento.

Sempre que um profissional é alocado para mais de um projeto ocorre um fenômeno nãolinear: ao adicionar o segundo projeto, a produtividade do profissional aumenta, para logo em seguida cair se ele for alocado no terceiro projeto. Quando um engenheiro é alocado para um único projeto, normalmente ele terá algum tempo ocioso por ter de esperar, em algumas ocasiões, pela conclusão de atividades de outras pessoas. Ao ingressar em outro projeto simultâneo, esse tempo ocioso pode ser gasto nesse segundo projeto. Logo, a produtividade 
do engenheiro tende a aumentar com esse segundo projeto. Contudo, se ele for designado para mais um, dois, ou mesmo três projetos, sua produtividade cai dramaticamente. Isso pode ser explicado pelo fato de que as atividades do projeto são compostas por atividades que agregam valor (programação, prototipagem, testes) e atividades que não agregam valor: documentação, relatórios, pesquisa de documentos etc (CLARK; WHEELWRIGHT, 1992).

Algumas vezes é necessário compartilhar pessoas com conhecimentos e habilidades específicos entre diversos projetos. Há uma percepção comum de que a empresa pode ser mais produtiva ao alocar seus recursos mais escassos para suportar múltiplos projetos. Essa percepção leva à crença errônea de que, se um engenheiro trabalha em dois projetos, então esse engenheiro vai produzir o dobro do trabalho no mesmo tempo. Em certas situações, essa abordagem é realmente verdadeira. Se o engenheiro tem capacidade ociosa, por algum motivo, sua carga de trabalho pode ser aumentada sem afetar o tempo de execução das atividades. Se as atividades executadas por esse engenheiro têm períodos obrigatórios de espera, tais como testes externos ou fabricação de protótipos, o aumento de trabalho pode ser acomodado facilmente. Nesse caso, contudo, o tempo de execução das tarefas depende do sequenciamento exato entre as várias atividades dos projetos (EVERS, 2000).

Enquanto a alternativa de multi-projetos pode parecer a reposta para o desejo dos gerentes em terminar mais projetos no mesmo tempo, os resultados das pesquisas apontam para outras direções. Sem alterações no modo de trabalho, dividir o pessoal entre múltiplos projetos pode custar mais e demorar mais tempo. Entretanto, com cuidadoso planejamento, identificação e sequenciamento dos projetos e de suas tarefas, essa pode ser uma alternativa vantajosa (EVERS, 2000).

\subsubsection{Fatores positivos, negativos e ações recomendadas na gestão do portfólio}

Cooper et al (1999) apontam que a maioria das empresas usa predominantemente abordagens financeiras na gestão do seu portfólio de projetos, mas revelou também que a abordagem financeira não produz os melhores resultados. Os portfólios de maior sucesso são aqueles obtidos por meio de um modelo híbrido, onde diversas ferramentas são usadas para permitir um tratamento sistêmico ao problema. O principal objetivo em um ambiente de múltiplos projetos que competem e compartilham os mesmos recursos é maximizar o sucesso global do departamento de desenvolvimento ao invés de privilegiar o sucesso de um único projeto em particular. Contudo, uma vez que os mecanismos de avaliação de performance 
usualmente levam em conta os resultados individuais dos projetos, os gerentes de projetos instintivamente tendem a tomar decisões na direção que é mais benéfica para o seu projeto. Um gerente forte pode ter grande sucesso no seu projeto, mas a organização como um todo, pode ser penalizada pelo atraso produzido em outros projetos do portfólio (FRICKE; SHENBAR, 2000).

A falta de atenção para essa interdependência leva os indivíduos a adotarem soluções racionais para os projetos tomados isoladamente, mas que podem ser inconsistentes e subótimas para o portfólio como um todo. Assim, é de suma importância que as organizações invistam mais recursos na gestão do mix de projetos. É interessante notar que problemas técnicos não aparecem como um dos fatores afetando o sucesso ou falha de um projeto, além de outros como aceitação dos clientes, problemas de manutenção, dentre outros. Os gerentes acreditam em geral que dividir e alocar recursos exclusivos para determinados projetos pode sustentar as atividades de desenvolvimento no longo prazo. Entretanto, a importância de alocar os recursos está relacionada à necessidade de flexibilização, experiência e redundância de pessoal para assumir tarefas inesperadas, migrando de um projeto para o outro (FRICKE; SHENBAR, 2000).

A priorização dos projetos de fato aparece como um dos fatores mais importantes. Ela é inextricavelmente ligada à disponibilidade de recursos. Em um departamento com muitos projetos pequenos, com diferentes dimensões de importância, as prioridades podem variar quase que diariamente. O maior desafio nesse ambiente é manter o foco dos recursos nos projetos mais prioritários sem comprometer os projetos menores e menos importantes. Então, há a clara necessidade de classificar os projetos usando algum tipo de tipologia para distinguilos. A comunicação representa um papel de suma importância no ambiente de multiprojetos. Além da comunicação interna no time do projeto, a comunicação apropriada e freqüente em todas direções, principalmente com a alta direção foi vista como sendo crítica para o sucesso dos empreendimentos (FRICKE; SHENBAR, 2000).

Finalmente, segundo Fricke e Shenbar (2000), seis habilidades gerenciais foram identificadas como sendo muito úteis nesse ambiente: liderança, motivação, planejamento, tomada de decisão, comunicação e predisposição para ensinar. Ainda que essas habilidades não seja específicas para um ambiente de multiprojetos, sua existência foi claramente mencionada como contribuindo para atingir a lista de fatores críticos para o sucesso.

De acordo com Cooper e Edgett (2003), a ênfase exagerada na redução do ciclo de projeto também é uma grande vilã na GPPNP. Além de intensificar os problemas inerentes ao processo, não há evidências de que a redução do tempo de desenvolvimento e lançamento de 
um novo produto produza resultados satisfatórios. Essa pressão normalmente é resultado de uma preocupação exagerada com o desempenho de curto prazo da organização, normalmente atrelada a resultados exclusivamente financeiros. As soluções estratégias propostas são as seguintes:

a. Reconhecer que os recursos variam de organização para organização e de projeto para projeto. Alguns projetos podem merecer mais investimentos em função da oportunidade e a análise deve capturar essa condição.

b. Para projetos inovadores, a empresa deve usar métricas apropriadas. Nem todos os projetos podem ser comparados e devem ser avaliados da mesma maneira.

c. A empresa deve criar uma estratégia de inovação tecnológica e de produtos para complementar a estratégia de negócios que a maioria das empresas já possui.

d. Garantir que os recursos para desenvolvimento de novos produtos são consistentes com as estratégias e objetivos do negócio.

e. Criar grupos dedicados para projetos prioritários, quando for necessário.

f. Implementar um processo formal para gestão do portfólio de projetos.

g. Manter o foco: desenvolver menos projetos, mas melhores. A gestão de portfólios eficiente também significa "empreender o número certo de projetos" concentrando os recursos em menos projetos, mas nos projetos certos.

As soluções operacionais (táticas) propostas por Cooper e Edgett (2003) para melhorar a gestão do portfólio e a alocação de recursos, são:

a. Entenda e visualize a alocação de recursos entre os projetos.

b. Exija que os times de projetos especifiquem datas e recursos necessários.

c. Adote uma abordagem de time para lidar com falta de recursos: na ausência de uma pessoa da equipe, outra pode assumir as tarefas.

Evers (2000) aponta para algumas formas de otimizar o tempo do pessoal de desenvolvimento. O objetivo principal é manter um fluxo contínuo de atividades que agregam valor, eliminando ou reduzindo as atividades inúteis ou que não agregam valor ao projeto e ao portfólio, dessa forma aumentando a produtividade. Outro ponto importante, segundo o autor, é reduzir o desperdício de tempo pela eliminação da frustração, assegurando que informações atualizadas estejam disponíveis a todos os interessados.

Elonen e Artto (2003) identificaram seis causas para os principais problemas de gestão de múltiplos projetos:

a. Atividades inadequadas na gestão dos projetos individualmente.

b. Escassez de recursos e falta de competências e métodos. 
c. Falta de comprometimento e de definição clara de papéis e responsabilidades.

d. Atividades inadequadas na gestão do portfólio de projetos.

e. Administração inadequada de negócios orientados a projetos.

A performance do portfólio pode estar também ligada à performance individual de cada projeto. Se a organização obtém excelentes resultados no desenvolvimento de projetos isolados, levanta-se a questão se ela poderá obter o mesmo sucesso ao desenvolver múltiplos projetos com recursos compartilhados. Existem evidências de que a performance do gerenciamento de cada projeto pode estar relacionada ao sucesso do portfólio como um todo (ELONEN; ARTTO, 2003).

Martinsuo e Lehtonen (2006) conduziram uma pesquisa com 279 empresas de desenvolvimento para verificar essa relação. A partir da premissa de que uma organização de desenvolvimento de produtos moderna empreende dezenas e até centenas de projetos simultaneamente, eles encontraram relações entre a gestão individualizada de cada projeto e a gestão do portfólio. Os gerentes de projetos, no nível de cada projeto individual, podem contribuir em termos mais amplos no negócio para beneficiar todo o portfólio de projetos. Há fortes evidências de que pelo menos a (a) definição de objetivos, (b) a disponibilidade de informações sobre os projetos para os gerentes e (c) a existência de um processo sistemático de tomada de decisão sobre os projetos, podem ser relacionados à eficiência no gerenciamento do portfólio.

Martinsuo e Lehtonen (2006) definem a eficiência na gestão do portfólio como sendo a estimativa, elaborada pelos membros da organização, do sucesso que os projetos obtém juntos, como um portfólio, em atingir os objetivos de alinhamento estratégico, o balanceamento entre projetos e a maximização do valor Segundo esses autores, o gerenciamento individual de projetos está associado diretamente com a eficiência do portfólio na forma de (a) disponibilidade de informação sobre os projetos e de (b) eficiência no gerenciamento de projetos. Também está relacionada indiretamente, na forma de (c) disponibilidade de informação, (d) definição de objetivos e (e) processo formal de decisão.

\subsection{INTERNACIONALIZAÇÃO DE EMPRESAS BRASILEIRAS}

O uso da teoria sobre internacionalização de empresas apresentada nessa pesquisa teve o objetivo de justificar a escolha de multinacionais brasileiras como foco de estudo, devido principalmente à evolução que essas empresas passaram no processo de concorrência em 
mercados externos. Considera-se que as multinacionais brasileiras possuem um nível superior de gestão que deve se refletir também na gestão de seus projetos de novos produtos. A partir da década de 80 , as empresas passaram a ver no cenário internacional vantagens de custo não apenas no atendimento aos mercados, mas possibilidades de integração internacional das diferentes atividades de valor (ARRUDA; GOULART; BRASIL, 1994).

Goulart (2004) afirma que a decisão de internacionalizar as atividades está ligada à preocupação da empresa em manter, fortalecer e ampliar sua penetração nos mercados-alvo e ganhar experiência gerencial e operacional. Uma vez tomada essa decisão, a empresa tem que definir qual o nível de envolvimento e comprometimento internacional pretende assumir. Essa decisão deve refletir a análise aprofundada do potencial do mercado e de suas próprias competências e recursos (financeiros, humanos, gerenciais). Isso nem sempre é seguido. Muitas empresas entram no mercado hesitantes e vão crescendo e expandindo suas atividades, à medida que ganham experiência. Então, mudam suas estratégias de acordo com o grau de comprometimento e amadurecimento adquirido. Outras empresas entram em mercados externos depois de muita pesquisa e com uma estratégia bem definida.

O fato de a empresa buscar novos mercados no exterior representa algumas vantagens, como acesso a outras matérias-primas, recursos naturais, mão-de-obra barata ou mais qualificada, ou tamanho do mercado. Assim, uma empresa pode instalar uma subsidiária com o objetivo principal de utilizar os recursos naturais e humanos de um país estrangeiro. Por outro lado, se a escolha for determinada pelo acesso a um mercado doméstico importante, isto significa acesso a canais de distribuição, proximidade com o mercado, custos de recursos e transporte (VIEIRA; ZILBOVICIUS, 2005).

Vieira e Zilbovicius (2005) argumentam que as empresas buscam a internacionalização para acessar novos mercados, conhecimentos e habilidades; racionalizar recursos e para adaptar produtos à demanda de mercados específicos. Nessa mesma perspectiva, Arruda, Goulart e Brasil (1994) avaliam o processo de internacionalização a partir de quatro concepções distintas: internacionalização como evolução da capacidade da exportação; internacionalização como uma busca para a competitividade tecnológica; internacionalização como consequiência da habilidade de agregar sócios e internacionalização como conseqüência de exposição internacional. Pelo perfil traçado nessa pesquisa para as empresas que farão parte do estudo multicaso entende-se que a maioria, senão todas, se enquadram primeira concepção.

Por fim, deve-se frisar que o estudo das empresas que atuam no exterior é extremamente relevante, pois essas empresas têm ocupado espaço cada vez maior no âmbito 
do processo de globalização da economia, apresentando resultados muitas vezes superiores aos da média de seu segmento. O conjunto de indústrias brasileiras com unidade produtivas no exterior é basicamente formado por empresas de médio e grande porte. Cabe mencionar que o processo de internacionalização dessas empresas ainda é algo recente, pois a maioria das unidades internacionais foi inaugurada nos últimos anos e estão concentradas nos continentes mais próximos ao país, como a América do Sul (ALTMANN, 2005). No quadro seguinte há uma lista com as principais empresas brasileiras com fábricas no exterior:

\begin{tabular}{|c|c|c|}
\hline \multicolumn{3}{|c|}{ INDÚSTRIAS BRASILEIRAS COM FÁBRICAS NO EXTERIOR } \\
\hline $\begin{array}{l}\text { Alpargatas } \\
\text { (EUA) }\end{array}$ & $\begin{array}{c}\text { Coteminas } \\
\text { (Argentina e EUA) }\end{array}$ & $\begin{array}{c}\text { Klabin } \\
\text { (Argentina) }\end{array}$ \\
\hline $\begin{array}{c}\text { Artecola } \\
\text { (México, Colômbia, Peru, Chile e } \\
\text { Argentina) }\end{array}$ & $\begin{array}{l}\text { Crystalsev } \\
\text { (El Salvador) }\end{array}$ & $\begin{array}{c}\text { Marcopolo } \\
\text { (Portugal, Argentina, México, África } \\
\text { do Sul e Colômbia) }\end{array}$ \\
\hline $\begin{array}{c}\text { Bertin } \\
\text { (Uruguai) }\end{array}$ & $\begin{array}{c}\text { CSN } \\
\text { (EUA e Portugal) }\end{array}$ & $\begin{array}{c}\text { Petrobrás } \\
\text { (EUA, Angola, Guiné Equatorial, } \\
\text { Líbia, EUA, Nigéria, Argentina, } \\
\text { Bolívia, Colômbia, Equador, México, } \\
\text { Irã, Peru e Venezuela) }\end{array}$ \\
\hline $\begin{array}{c}\text { Busscar } \\
\text { (Cuba, México, Venezuela, Noruega e } \\
\text { Colômbia) }\end{array}$ & $\begin{array}{l}\text { Cutrale } \\
\text { (EUA) }\end{array}$ & $\begin{array}{c}\text { Sabó } \\
\text { (Argentina, Alemanha Hungria) }\end{array}$ \\
\hline $\begin{array}{c}\text { Camargo Corrêa Cimentos } \\
\text { (Argentina, Bolívia, Paraguai e } \\
\text { Uruguai) }\end{array}$ & $\begin{array}{l}\text { Duas Rodas Industrial } \\
\text { (Argentina, Chile e Peru) }\end{array}$ & $\begin{array}{c}\text { Santista Têxtil } \\
\text { (Argentina, Chile e Espanha) }\end{array}$ \\
\hline $\begin{array}{l}\text { Cinex } \\
\text { (México) }\end{array}$ & $\begin{array}{c}\text { Duratex } \\
\text { (Argentina, Bélgica e } \\
\text { EUA) }\end{array}$ & $\begin{array}{c}\text { Smar } \\
\text { (EUA, Venezuela) }\end{array}$ \\
\hline $\begin{array}{l}\text { Citrosuco } \\
\text { (EUA) }\end{array}$ & $\begin{array}{c}\text { Embraco } \\
\text { (Itália, China e } \\
\text { Eslováquia) } \\
\end{array}$ & $\begin{array}{c}\text { Tubos Tigre } \\
\text { (Paraguai, Chile, Argentina e Bolívia) }\end{array}$ \\
\hline $\begin{array}{l}\text { Coimex } \\
\text { (Jamaica) }\end{array}$ & $\begin{array}{c}\text { Embraer } \\
\text { (China e Portugal) }\end{array}$ & $\begin{array}{c}\text { Vale do Rio Doce } \\
\text { (EUA, Chile, Peru, França, Noruega, } \\
\text { Gabão, África do Sul, Moçambique, } \\
\text { Î́ndia, China e Mongólia) }\end{array}$ \\
\hline $\begin{array}{l}\text { Construções e Comércio Camargo } \\
\text { Correia } \\
\text { (Colômbia, Peru, Bolívia, Suriname, } \\
\text { Angola, Moçambique e África do Sul) }\end{array}$ & $\begin{array}{l}\text { Forjas Taurus } \\
\quad \text { (EUA) }\end{array}$ & $\begin{array}{l}\text { Votorantim Metais } \\
\text { (Peru) }\end{array}$ \\
\hline $\begin{array}{c}\text { Construtora Norberto Odebrecht } \\
\text { (Angola, Argentina, Colômbia, } \\
\text { Equador, EUA, Peru, Portugal e } \\
\text { Venezuela) }\end{array}$ & $\begin{array}{c}\text { Friboi } \\
\text { (Argentina) }\end{array}$ & $\begin{array}{l}\text { Votorantim Cimentos } \\
\text { (EUA, Canadá) }\end{array}$ \\
\hline $\begin{array}{l}\text { Coopinhal } \\
\text { (Rússia) }\end{array}$ & $\begin{array}{c}\text { Gerdau } \\
\text { (Uruguai, Canadá, } \\
\text { Argentina, Chile, EUA, } \\
\text { Colômbia, Peru) }\end{array}$ & $\begin{array}{c}\text { WEG } \\
\text { (Portugal, China, Argentina, México) }\end{array}$ \\
\hline
\end{tabular}

Quadro 6 - Empresas brasileiras com fábricas no exterior

Fonte: adaptado de Costa, (2007), p. 79. 
A inserção das empresas brasileiras no exterior é normalmente motivada pela urgência de se atender as necessidades dos mercados estrangeiros e a forma de inserção internacional dessas empresas tente a ser por aquisição. Ressalta-se ainda que as empresas de médio porte participam expressivamente da internacionalização brasileira em termos de manufatura. De forma geral é possível constatar entre essas empresas duas características importantes: o fato de apresentarem grande know-how em termos de tecnologia e de liderarem seus mercados no Brasil (ALTMANN, 2005).

A economia mundial favorece cada vez mais os países que possuem uma indústria inovadora, sobretudo os países emergentes. Uma recente pesquisa (INNOVATION, 2007) realizada com 400 executivos de indústrias multinacionais revelou que países como Brasil, Rússia, Índia e China apresentam um crescimento superior à média do mercado internacional, atraindo investimentos e apresentando também um forte comércio exterior, por meio de exportações, filiais e subsidiárias em outros países. As conclusões dessa pesquisa apontam a inovação local como fator decisivo para o sucesso da indústria nesses mercados. Essa inovação local consiste em conceber, projetar, desenvolver, lançar e fabricar produtos de forma a atender às expectativas particulares de cada um desses mercados. Essas expectativas incluem preço, características, materiais, design, canais, dentre outros atributos. 


\section{III - ASPECTOS METODOLÓGICOS}

Este capítulo esclarece os procedimentos metodológicos utilizados na elaboração e condução deste trabalho, explicando a importância do método científico, o tipo de pesquisa que foi desenvolvida, bem como as etapas e perguntas de pesquisa, coleta, plano de análise e apresentação dos dados e resultados.

Karl Popper (1956, p. 10) nos previne, com certo humor, que a tarefa de compreender o método científico não é das mais triviais:

Em geral, começo minhas lições sobre Método Científico dizendo aos meus
alunos que o método científico não existe. Acrescento que tenho obrigação
de saber isso, tendo eu sido, durante algum tempo pelo menos, o único
professor desse inexistente assunto em toda a Comunidade Britânica. Tendo
então, explicado aos meus alunos que não há essa coisa que seria o método
científico, apresso-me a começar o meu discurso, e ficamos ocupadíssimos.
Pois um ano mau chega para roçar a superfície mesmo de um assunto
inexistente.

$\mathrm{O}$ ato de pesquisar pode ser definido genericamente como a execução de um procedimento intelectual para adquirir novos conhecimentos, pela investigação de uma realidade e busca de novas verdades sobre um fato ou problema. Utilizando métodos adequados e técnicas apropriadas, o pesquisador busca conhecimentos específicos, respostas e solução ao problema estudado. A partir dos novos conhecimentos adquiridos pode haver o progresso científico, produto da atividade humana, para a qual o homem, compreendendo o contexto no qual está inserido, passa a desenvolvê-lo por meio de novas descobertas. Assim, o homem utiliza diversas formas de conhecimentos, buscando evoluir o meio que vive, trazendo contribuições para a sociedade (FACHIN, 2001).

Com base nessas premissas, buscou-se definir um plano de pesquisa científico, de forma que sua elaboração e execução pudessem contribuir para a formação do pesquisador, atingindo os objetivos do curso de mestrado (formação científica básica por meio da capacitação na utilização de métodos e técnicas de investigação científica e aprimoramento acadêmico e profissional). Ao mesmo tempo, o plano de pesquisa deveria contribuir na obtenção de resultados relevantes para o conhecimento acadêmico sobre o tema de gestão do portfólio de projetos de novos produtos. 


\subsection{TIPO DE PESQUISA}

Essa pesquisa foi do tipo qualitativa, pois se considerou ser essa a melhor abordagem para investigar as práticas em gestão do portfólio de projetos de novos produtos (GPPNP). Como a GPPNP se trata de um complexo fenômeno social, compreendendo uma rede de relações interdepartamentais, a pesquisa qualitativa é a forma adequada para se entender a natureza desse fenômeno (RICHARDSON, 1999).

Esse estudo utilizou uma abordagem exploratória, uma vez que objetivo foi familiarizar-se com o fenômeno da GPPNP, procurando responder às questões de pesquisa e servir de base à formulação de um problema mais preciso ou criar novas hipóteses que poderão ser testadas em outras pesquisas (SELLTIZ, 1987; GIL, 2002).

A técnica de pesquisa empregada foi o estudo multicaso. Segundo Yin (2001), o estudo de caso deve ser a estratégia adotada quando as questões a serem respondidas são do tipo "como" ou "por que", quando o pesquisador possui pouco controle sobre os eventos a serem investigados e quando o foco está em um fenômeno contemporâneo inserido em um contexto na vida real. Três condições determinaram que o estudo de caso deveria ser a técnica usada. A primeira foi o tipo de questão de pesquisa a ser respondida, do tipo "como". A segunda, o nível muito baixo ou nulo de controle que o pesquisador possuía sobre os fenômenos a serem pesquisados e, por fim, a terceira condição foi que o foco da pesquisa é um fenômeno contemporâneo e não um fenômeno histórico. Uma das vantagens da utilização do estudo de caso é que, “... o estudo de caso permite à pesquisa manter as características holísticas e mais significativas de eventos da vida real...". Ainda que os comportamentos relevantes não possam ser manipulados, é possível realizar observações diretas e entrevistas sistemáticas, lidando com uma completa variedade de evidências: documentos, artefatos, entrevistas e observações (YIN, 2001). O estudo de caso é caracterizado por ser um estudo intensivo que produz uma grande quantidade de informação sobre o tema investigado. É levada em consideração a compreensão do assunto investigado como um todo. O estudo de caso não é uma técnica específica, e sim um meio de organizar dados sociais, preservando o caráter unitário do objeto social estudado (FACHIN, 2001).

Segundo Boyd e Westfall (1987), o estudo multicaso tem se mostrado conveniente na identificação de três tipos de fatores: (a) fatores comuns a todos os casos no grupo escolhido; (b) fatores não comuns a todos, mas apenas a alguns subgrupos e (c) fatores únicos em caso específico. Além disso, Yin (2001) reforça que, freqüentemente, a evidência resultante de um estudo multicaso é considerada mais determinante, e o estudo como um todo, mais robusto. A 
lógica de utilização do método de estudo de multicaso diz respeito à replicação das evidências e não à simples amostragem. Outro ponto de aplicabilidade neste estudo é que ele trata de um fenômeno contemporâneo, num contexto de situação real, utilizando múltiplas fontes de evidência.

As questões de pesquisa foram abordadas com uma investigação de natureza empírica, baseada no trabalho de campo, no contexto real, tendo fontes múltiplas de evidência como entrevistas, observações, documentos e dados financeiros das diversas empresas, constituindo então o estudo multicaso. Triviños (1992) afirma que o estudo multicaso difere do estudo comparativo de casos, pelo fato de propiciar ao pesquisador a possibilidade de estudar duas ou mais organizações sem a necessidade de perseguir objetivos de natureza comparativa. Assim, a partir do estudo multicaso procurou-se identificar as práticas usadas na gestão do portfólio de projetos de novos produtos, tendo como referência os modelos teóricos de Rabechini Júnior, Maximiano e Martins (2005), Cooper (1994), Archer e Ghasemzadeh (1999) e do PMI (2006b).

\subsection{PERGUNTAS DA PESQUISA}

A pergunta central dessa pesquisa, já apresentada na introdução, é: como as multinacionais brasileiras gerenciam seu portfólio de projetos de novos produtos? Essa questão geral se desdobra em outras questões, em consonância com os objetivos específicos:

a. Quais as práticas mais empregadas na gestão do portfólio de projetos de novos produtos nas multinacionais brasileiras?

b. As práticas de gestão identificadas nas empresas seguem os modelos teóricos?

c. Qual a relação entre as práticas de gestão do portfólio utilizadas pelas empresas?

d. Como as unidades estrangeiras participam do processo de gestão do portfólio?

\subsection{DEFINIÇÃO DE TERMOS}

A seguir são apresentadas as definições para os termos essenciais utilizados ao longo dessa pesquisa:

a. Inovação tecnológica: processo interativo que engloba a transformação do conhecimento científico em bens e serviços (SBRAGIA; KRUGLIANSKAS; CAMARGOS, 1998). 
b. Internacionalização de empresas: processo de envolvimento de uma empresa nas operações com outros países fora de sua base de origem (ARRUDA; GOULART; BRASIL, 1994).

c. Multinacionais brasileiras: toda empresa que atenda aos seguintes requisitos: (a) realizar atividades industriais de transformação; (b) ter origem histórica e/ou controle acionário brasileiro; (c) ter unidades fabris e/ou P\&D em outros países.

d. Projeto: empreendimento temporário para criar um produto, serviço ou resultado único (PMI, 2004).

e. Programa: um grupo de projetos gerenciados de forma coordenada com o objetivo de obter benefícios e controle que não seriam possíveis caso fossem gerenciados individualmente (PMI, 2006a).

f. Portfólio: conjunto de projetos que compartilham e competem pelos recursos da organização, sejam eles financeiros, tecnológicos, humanos ou outros quaisquer (ARCHER; GHASEMZADEH, 1999; COOPER et al., 1997, 1999, 2001; PMI, 2006b; MARTINSUO; LEHTONEN, 2006).

g. Gestão do portfólio: esse termo será usado de forma equivalente ao termo "gestão do portfólio de projetos de novos produtos" (GPPNP). É o gerenciamento de projetos ou programas de forma sistêmica, incluindo a avaliação, seleção, priorização e balanceamento de projetos com objetivos estratégicos de criação de valor, por meio de um processo dinâmico e repetitivo no qual a empresa decide investir seus recursos, buscando maximizar o valor do portfólio. A gestão do portfólio também pode ser entendida como uma abordagem gerencial para atingir os objetivos estratégicos da empresa (RABECHINI JÚNIOR; MAXIMIANO; MARTINS, 2005; COOPER et al., 1997; DYE; PENNYPACKER, 2000; PMI, 2004, 2006b; MARTINSUO; LEHTONEN, 2006).

h. Gestão de múltiplos projetos: alocação dos recursos da organização entre os vários projetos ativos, com o objetivo de equilibrar o uso desses recursos de acordo com as prioridades atribuídas a cada projeto (DYE; PENNYPACKER, 2000; COOPER et al., 2001).

i. Ciclo de Gestão do Portfólio: período compreendido entre sucessivas revisões do portfólio de projetos (PMI, 2006b).

j. Desenvolvimento de novos produtos: processo formal que orienta o projeto de um novo produto desde a idéia inicial até seu lançamento. Inclui informações sobre o mercado que são por sua vez transformadas nas informações e bens necessários para a produção de um 
produto com fins comerciais (CLARK; FUJIMOTO, 1991; COOPER, 1994; UTTERBACK, 1996).

k. Práticas de gestão: ações administrativas planejadas e executadas em uma ou mais fases, com o objetivo de transformar as idéias de novos produtos em resultados tangíveis e intangíveis para a organização por meio de projetos. Os processos e atividades descritos nos modelos de Rabechini Júnior, Maximiano e Martins (2005), Cooper (1994), Archer e Ghasemzadeh (1999) e do PMI (2006b) foram usadas como referências para a identificação das práticas de gestão investigadas no estudo multicaso.

\subsection{ETAPAS DA PESQUISA}

Como o objetivo é investigar e entender melhor o fenômeno da gestão do portfólio de projetos de novos produtos nas multinacionais brasileiras, o estudo multicaso foi precedido por um planejamento composto por uma série de procedimentos metodológicos. A partir da revisão da literatura em inovação, gestão do portfólio de projetos de novos produtos e multinacionais brasileiras, foi possível traçar um perfil do tipo de empresa a ser pesquisada com os respectivos critérios para seleção dos casos (ALTMANN, 2005; SBRAGIA; KRUGLIANSKAS; CAMARGOS， 1998; ARRUDA; GOULART; BRASIL， 1994; GOULART, 2004).

Após a revisão da literatura, o protocolo de pesquisa foi criado, levando em conta a seleção de pessoas bem como o número de entrevistas a serem realizadas. Uma agenda para atender aos objetivos da coleta de dados foi preparada, bem como um roteiro com as principais questões do estudo de caso para orientação durante a entrevista (RABECHINI JÚNIOR; MAXIMIANO; MARTINS, 2005; ARCHER; GHASEMZADEH, 1999; COOPER et al., 1997; PMI, 2004, 2006a, 2006b).

$\mathrm{Na}$ figura seguinte estão ilustradas as principais etapas da pesquisa, de acordo com os objetivos específicos propostos. 


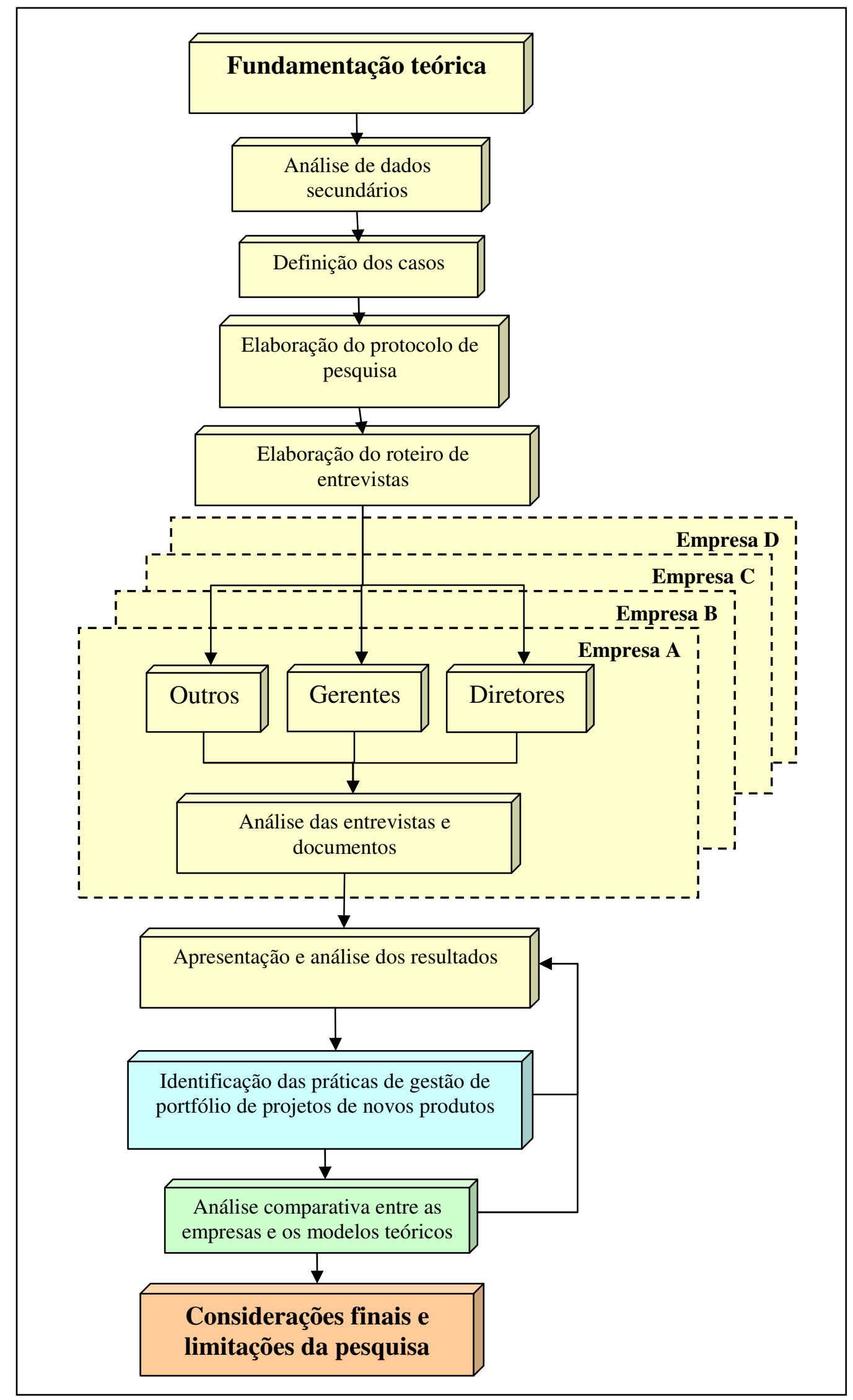

Figura 13 - Etapas da pesquisa

Fonte: adaptado de Rabechini Júnior, Maximiano e Martins, (2005), p. 422. 


\subsection{COLETA DE DADOS: TIPOS, MÉTODOS E CASOS}

A coleta de dados foi uma etapa fundamental na execução dessa pesquisa. Pelo fato de se utilizar uma estratégia de multicaso, foi necessário um extenso levantamento de dados antes que a pesquisa de campo fosse iniciada. A seguir, descrevem-se os tipos de dados utilizados na pesquisa, os métodos usados para seu levantamento e a forma com a qual foram analisados.

\subsubsection{Tipos de dados}

Foram utilizados dados primários e secundários:

a. Os dados primários foram obtidos diretamente nas empresas por meio de entrevistas realizadas pelo pesquisador com gestores ligados ao processo de GPPNP.

b. Os dados secundários, que são aqueles já coletados e que se encontram organizados em arquivos, bancos de dados e anuários estatísticos, relatórios, dentre outras fontes similares, foram obtidos por meio de acesso a documentos e aos bancos de dados de projetos das empresas (MARTINS, 2006).

\subsubsection{Técnicas de coleta de dados}

Os dados primários foram obtidos com auxílio de um roteiro de perguntas (ANEXO A) aplicado em entrevistas semi-estruturadas com gestores, desenvolvedores e pessoas ligadas direta ou indiretamente às atividades de $\mathrm{P} \& \mathrm{D}$ nas empresas. As entrevistas semi-estruturadas são bastante adequadas para a obtenção de informações sobre as crenças, expectativas, o que fizeram e o que pretendem fazer, além de explicações e impressões sobre os fatos em análise (GIL, 2002).

As entrevistas tiveram como alvo pessoas ligadas diretamente às atividades de desenvolvimento de novos produtos, com os seguintes perfis:

a. Diretores e/ou gerentes: obter informações de caráter estratégico, objetivos gerais do negócio e do portfólio de projetos. Obter também informações ligando a estratégia e 
objetivos do negócio com informações de caráter operacional (tático) sobre a gestão dos projetos e sobre o processo de desenvolvimento de produtos.

b. Desenvolvedores: informações sobre o dia-a-dia da implementação dos projetos, o que acontece realmente em termos de práticas gerenciais, resolução de conflitos, mudanças de prioridade nos projetos, dentre outras.

c. Outras pessoas ligadas indiretamente ao desenvolvimento de produtos: por exemplo, pertencentes a outras áreas funcionais (marketing, vendas, assistência técnica, fabricação), para obter informações que completem e ajudem a validar a coerência das informações obtidas dos outros entrevistados.

\subsubsection{Estratégia de análise dos dados}

Para analisar as informações obtidas na entrevistas, utilizou-se o seguinte procedimento: análise documental, transcrição das entrevistas, análise de conteúdo, elaboração de relatório de cada um dos casos e comparação com o referencial teórico. A análise documental consistiu na análise dos vários documentos coletados com o objetivo de descobrir as circunstâncias sociais e econômicas com as quais estavam relacionados (RICHARDSON, 1999).

A transcrição das entrevistas gravadas facilitou a análise das informações obtidas, pois permitiu a leitura e reflexão sistemática sobre as opiniões e dados fornecidos pelos entrevistados, além de permitir a busca de evidência em cada tema analisado e sua posterior análise de conteúdo. A análise de conteúdo permitiu obter das entrevistas transcritas indicadores qualitativos que permitiram inferir conhecimentos relativos ao fenômeno estudado (BARDIN, 1979¹ apud RICHARDSON, 1999).

Yin (2001) apresenta duas estratégias para a análise das evidências encontradas nos casos: confiança nas proposições teóricas e o desenvolvimento da descrição do caso. Esta pesquisa valeu-se dessa última estratégia para a elaboração de um esquema descritivo, organizando o estudo multicaso em temas relacionados aos principais processos da gestão do portfólio, segundo os modelos teóricos. Esse esquema descritivo foi usado para identificar as práticas gerenciais em cada empresa.

\footnotetext{
${ }^{1}$ BARDIN, L. Análise de Conteúdo. Lisboa: Edições 70, 1979. 223 p.
} 
Após a coleta de dados, um relatório de cada estudo de caso foi elaborado de acordo com o modelo do ANEXO B. Esse relatório continha um histórico resumido de cada uma das empresas (ANEXOS C a F), bem como as informações obtidas nos documentos e entrevistas, organizadas em tópicos alinhados com objetivos da pesquisa. Cada empresa recebeu seu respectivo relatório e após sua revisão, o mesmo foi aprovado pelos representantes de cada empresa para uso nessa pesquisa.

Finalmente, a análise dos casos foi elaborada para a apresentação dos dados, levando em conta o conjunto das informações obtidas de todas as empresas. Esse conjunto de informações foi analisado à luz do referencial teórico utilizado na pesquisa, para elaborar explicações sobre os casos, tecer algumas considerações sobre as explicações alternativas e apresentar algumas conclusões baseadas nas evidências encontradas (YIN, 2001).

\subsubsection{Definição dos casos}

O perfil traçado para escolha das empresas que fizeram parte do estudo multicaso utilizou seis critérios, de acordo com o quadro seguinte:

\begin{tabular}{|ll|l|}
\hline \multicolumn{2}{|c|}{ CRITÉRIO } & \multicolumn{1}{c|}{ FONTE } \\
\hline 1. & Realizar atividades industriais de transformação & Tabela CNAE IBGE 2007 \\
\hline 2. & Ter origem histórica e/ou controle acionário brasileiro. & Dados secundários. \\
\hline 3. & Ter unidades fabris e/ou P\&D em outros países. & Dados secundários. \\
\hline 4. & $\begin{array}{l}\text { Desenvolver e lançar novos produtos com freqüência } \\
\text { no mínimo anual em quaisquer mercados onde atue. }\end{array}$ & Dados secundários. \\
\hline 5. & Ser líder nacional no seu segmento de atuação. & Dados primários e/ou secundários. \\
\hline $\begin{array}{l}\text { 6. } \\
\text { Aceitar a participação na pesquisa concedendo } \\
\text { entrevistas e/ou respondendo a questionários. }\end{array}$ & $\begin{array}{l}\text { Consulta prévia a potenciais } \\
\text { participantes. }\end{array}$ \\
\hline
\end{tabular}

\section{Quadro 7 - Critérios para seleção dos casos}

A partir da fundamentação teórica sobre internacionalização de empresas foi identificado um primeiro conjunto de empresas candidatas. Seguiram-se contatos com algumas dessas empresas, selecionadas observando-se inicialmente sua localização geográfica, para otimizar a coleta de dados. Dentre as empresas consultadas, quatro delas foram selecionadas por preencherem todos os requisitos: ALFA ${ }^{1}$, BETA ${ }^{1}$, TIGRE e WEG. Essas empresas, apesar de atuarem em segmentos diferentes, possuem uma série de

\footnotetext{
${ }^{1}$ Nomes fictícios.
} 
características comuns: são líderes em seus segmentos no Brasil; já ganharam o prêmio de Inovação Tecnológica da FINEP pelo menos uma vez; todas afirmaram conhecer o tema de gestão do portfólio de novos produtos e aceitam conceder entrevistas.

- ALFA: líder em sua área de atuação. Cerca de 69\% de seu faturamento advém de produtos lançados há menos de 4 anos. Possui dezenas de patentes depositadas e investe cerca de $3 \%$ de seu faturamento em P\&D. Possui fábricas e equipes de desenvolvimento no Brasil e no exterior. Mantém intensa cooperação com universidades do Brasil e do exterior para o desenvolvimento de novas tecnologias e produtos. Já foi vencedora do Prêmio FINEP de Inovação Tecnológica (FINEP, 2007).

- BETA: líder nacional na sua área de atuação. Fabrica e desenvolve seus produtos no Brasil e em subsidiárias no exterior. Investe em média mais de $6 \%$ do seu faturamento em P\&D. Possui dezenas de patentes registradas, com diversos pedidos em andamento. Cerca de $10 \%$ de seu faturamento é proveniente de produtos lançados há menos de três anos. Foi vencedora do prêmio FINEP de Inovação Tecnológica (FINEP, 2007).

- TIGRE: localizada em Joinville, SC, é líder nacional na fabricação de tubos e conexões de PVC. Lançou centenas de novos produtos nos últimos anos, ingressando em diversos novos segmentos tais como móveis, acessórios para cozinha e banheiros, dentre outros. Possui diversas fábricas no exterior e o P\&D é centralizado no Brasil. Cerca de $12 \%$ de seu faturamento advêm de produtos novos, com menos de três anos de vida. A empresa mantém convênios e parcerias com universidades e já conta com 25 patentes no Brasil e no exterior. Foi vencedora de várias categorias do Prêmio FINEP de Inovação Tecnológica (TIGRE, 2007; FINEP, 2007).

- WEG: a Divisão de Motores é a maior do grupo e foi o alvo da pesquisa. Está localizada em Jaraguá do Sul, SC. É a líder nacional e quarta maior fabricante mundial de motores elétricos. Possui fábricas e P\&D em diversos países e uma grande linha de produtos renovada freqüentemente. A empresa possui grande tradição no desenvolvimento tecnológico do seu segmento, detendo várias patentes. Também vencedora do prêmio FINEP de Inovação Tecnológica (WEG, 2007; FINEP, 2007). 


\subsection{PROTOCOLO DE PESQUISA}

O protocolo de pesquisa é um instrumento que orienta o pesquisador na condução do estudo de caso, sendo uma ferramenta que contribui para a confiabilidade da pesquisa. Este instrumento constitui um conjunto procedimentos e informações suficientes para se replicar o estudo, ou aplicá-lo a outros casos. Isso dá condições práticas para testar a confiabilidade da pesquisa, pois oferece a segurança de que o trabalho foi planejado. O protocolo do estudo de caso compreende os procedimento de campo e as questões do estudo de caso (YIN, 2001; MARTINS, 2006).

\subsubsection{Procedimentos de campo}

Antes do contato com as empresas selecionadas, foi elaborado um estudo sobre cada uma delas, baseado apenas em dados secundários. Este estudo contém um histórico da empresa, informações sobre faturamento, atividades e investimentos em $\mathrm{P} \& \mathrm{D}$, freqüência no lançamento de produtos, presença internacional, estrutura organizacional, localização das unidades e uma série de outros fatores importantes para o conhecimento prévio do ambiente aonde os dados foram coletados.

Seguiu-se então um contato preliminar com cada empresa, por e-mail e por telefone, informando a intenção de visitá-la e entrevistar pessoas ligadas às áreas de $\mathrm{P} \& \mathrm{D}$, para coletar informações sobre o processo de gestão do portfólio de novos produtos. Foi pedido aos contatos em cada empresa que solicitassem voluntários com os perfis necessários para a pesquisa e que agendassem horários para as entrevistas, de preferência concentrando as entrevistas no mesmo dia para otimizar a visita às empresas. Para auxiliar nessa tarefa foi enviado um resumo das principais questões que seriam abordadas. As entrevistas seguiram o roteiro apresentado no ANEXO A.

Após um período de negociação com cada empresa para o agendamento das visitas, as entrevistas realizadas. Após as entrevistas seguiram-se diversos contatos por telefone e e-mail para complementar e revisar as informações obtidas nas entrevistas e nos documentos fornecidos pelas empresas. O quadro seguinte lista os $\operatorname{cargos}^{1}$ dos participantes:

\footnotetext{
${ }^{1}$ Os nomes dos participantes foram omitidos a pedido das empresas.
} 


\begin{tabular}{|l|l|}
\hline \multirow{4}{*}{ EMIPRESA } & \multicolumn{1}{c|}{ CARGOS DOS PARTICIPANTES } \\
\hline \multirow{4}{*}{ ALFA } & Gestor de marketing \\
\cline { 2 - 2 } & Gestor corporativo de projetos \\
\cline { 2 - 2 } & Gestor de relações institucionais \\
\cline { 2 - 2 } & Gestor do escritório de projetos de tecnologia \\
\hline \multirow{2}{*}{ BETA } & Engenheiro de desenvolvimento \\
\cline { 2 - 2 } & Gerente de grupo especialista \\
\cline { 2 - 2 } & Coordenador de projetos \\
\hline \multirow{2}{*}{ TIGRE } & Gerente de PD\&E \\
\cline { 2 - 2 } & Líder de projetos \\
\hline \multirow{3}{*}{ WEG } & Gerente do departamento de P\&D do produto \\
\cline { 2 - 2 } & Gerente de engenharia de motores \\
\cline { 2 - 2 } & Gerente de engenharia \\
\cline { 2 - 2 } & Chefe de seção do P\&D \\
\hline
\end{tabular}

Quadro 8 - Cargos dos participantes de cada empresa

\subsubsection{Questões do estudo de caso}

As questões do estudo de caso são aquelas elaboradas para o pesquisador e não para os entrevistados. Essas questões auxiliaram o pesquisador a manter o foco nas informações mais importantes que foram coletadas, e os motivos para isso. As questões foram elaboradas a partir da perspectiva de um caso individual, que corresponde à unidade básica de coleta de dados. Observa-se que cada questão do estudo de caso foi acompanhada de prováveis fontes de evidência (YIN, 2001).

O referencial teórico da pesquisa forneceu o suporte para o estudo de caso conduzido em cada uma das empresas. A partir deste referencial, um roteiro de entrevistas foi elaborado, com justificativas e explicações relacionadas a cada questão. O roteiro de entrevistas e suas justificativas se encontram detalhados no ANEXO A. 


\section{IV - APRESENTAÇÃO E ANÁLISE DOS RESULTADOS}

Este capítulo apresenta e analisa os resultados obtidos por meio do estudo multicaso, de forma a atender os objetivos dessa pesquisa de acordo com o método proposto. Para cada uma das empresas, ALFA, BETA, TIGRE e WEG, foram elaborados relatórios a partir dos quais as práticas relacionadas à gestão do portfólio de projetos de novos produtos foram identificadas e mapeadas nos processos sugeridos pelos modelos teóricos.

O ambiente onde ocorre a maiorias das atividades da gestão do portfólio é descrito inicialmente na seção 4.1, que apresenta a estrutura de desenvolvimento de produtos de cada empresa, indicando também a participação das unidades do exterior no processo de desenvolvimento de novos produtos e na gestão do portfólio. O conhecimento dessa estrutura facilita a compreensão dos processos que serão apresentados nas seções posteriores. Em seguida, tendo como base os resultados obtidos nos estudos de caso e os modelos teóricos de referência de Rabechini Júnior, Maximiano e Martins (2005), Archer e Ghasemzadeh (1999), Cooper (1994) e PMI (2006b), três processos foram utilizados para agrupar as informações sobre a gestão do portfólio de projetos de novos produtos em cada uma das empresas estudadas. Esses processos são chamados de processos agregados de gestão do portfólio e serão apresentados e analisados nas seções 4.2, 4.3 e 4.4. São eles: planejamento estratégico de novos produtos e tecnologias; formação do portfólio pela categorização, seleção e priorização dos projetos e, acompanhamento dos projetos e revisões no portfólio.

Após a análise crítica de cada um dos processos apresenta-se um quadro resumo com as principais características identificadas, de forma comparativa. Na seção 4.5 é apresentada uma análise conjunta, com a comparação entre os casos e cada um dos modelos teóricos.

No quadro seguinte estão listados os processos dos modelos teóricos e sua relação com os processos agregados usados na descrição dos casos: 


\begin{tabular}{|c|c|c|c|c|c|c|c|c|c|c|c|}
\hline Modelo teórico & \multicolumn{11}{|c|}{ Processos da gestão do portfólio desde a concepção até o lançamento do produto } \\
\hline \multirow[t]{2}{*}{ PMI } & \multirow{2}{*}{$\begin{array}{l}\text { Planejamento } \\
\text { estratégico }\end{array}$} & \multirow[t]{2}{*}{ Identificação } & \multirow[t]{2}{*}{ Categorização } & \multirow{2}{*}{\multicolumn{2}{|c|}{ Avaliação }} & \multirow[t]{2}{*}{ Seleção } & \multirow[t]{2}{*}{ Priorização } & \multirow[t]{2}{*}{ Balanceamento } & \multirow[t]{2}{*}{ Autorização } & $\begin{array}{l}\text { Revisão e } \\
\text { acompanhamento } \\
\text { do portfólio }\end{array}$ & \multirow{2}{*}{$\begin{array}{l}\text { Mudança } \\
\text { estratégica }\end{array}$} \\
\hline & & & & & & & & & & $\begin{array}{c}\text { Execução e } \\
\text { acompanhamento } \\
\text { dos componentes }\end{array}$ & \\
\hline \multirow{2}{*}{ ARCHER } & \multirow{2}{*}{$\begin{array}{l}\text { Desenvolvimento } \\
\text { da estratégia }\end{array}$} & \multirow{2}{*}{$\begin{array}{l}\text { Propostas de } \\
\text { novos } \\
\text { projetos }\end{array}$} & \multirow[t]{2}{*}{ Pré-avaliação } & \multirow{2}{*}{$\begin{array}{l}\text { Análise } \\
\text { do projeto } \\
\text { isolado }\end{array}$} & \multirow{2}{*}{$\begin{array}{l}\text { Avaliação } \\
\text { de } \\
\text { sinergias }\end{array}$} & \multirow{2}{*}{\multicolumn{2}{|c|}{ Seleção do portfólio ótimo }} & \multirow{2}{*}{\multicolumn{2}{|c|}{ Ajustes finais no portfólio }} & $\begin{array}{l}\text { Reavaliação dos } \\
\text { projetos }\end{array}$ & \multirow{2}{*}{$\begin{array}{l}\text { Finalização } \\
\text { com sucesso }\end{array}$} \\
\hline & & & & & & & & & & $\begin{array}{l}\text { Desenvolvimento } \\
\text { dos projetos }\end{array}$ & \\
\hline COOPER & \multicolumn{2}{|c|}{ Geração da idéia } & $\begin{array}{l}\text { Definição do } \\
\text { escopo }\end{array}$ & \multicolumn{4}{|c|}{ Avaliação do negócio } & Desenvolvimento & $\begin{array}{c}\text { Teste e } \\
\text { validação }\end{array}$ & Lançamento & $\begin{array}{l}\text { Revisão após } \\
\text { lançamento }\end{array}$ \\
\hline RABECHINI & $\begin{array}{l}\text { Preparação do } \\
\text { processo }\end{array}$ & Identificação & \multicolumn{3}{|c|}{ Avaliação } & \multicolumn{4}{|c|}{ Constituição da carteira } & Administração & $\begin{array}{l}\text { Revisão e } \\
\text { controle }\end{array}$ \\
\hline $\begin{array}{c}\text { PROCESSOS } \\
\text { AGREGADOS }\end{array}$ & \multicolumn{2}{|c|}{$\begin{array}{l}\text { Planejamento estratégico de novos } \\
\text { produtos e tecnologias }\end{array}$} & \multicolumn{7}{|c|}{ Formação do portfólio de projetos: categorização, seleção e priorização } & \multicolumn{2}{|c|}{$\begin{array}{l}\text { Acompanhamento dos projetos e } \\
\text { revisões no portfólio }\end{array}$} \\
\hline
\end{tabular}

Quadro 9 - Relação entre os processos dos modelos teóricos de referência

Fonte: PMI (2006b), Archer e Ghasemzadeh (1999), Cooper (1994), Rabechini Júnior, Maximiano e Martins (2005). 


\subsection{ESTRUTURA PARA O DESENVOLVIMENTO DE NOVOS PRODUTOS}

Esta seção apresenta informações sobre as estruturas de desenvolvimento de produtos de cada uma das empresas, na ordem ALFA, BETA, TIGRE e WEG, apontando suas principais características com relação à estrutura organizacional, o tamanho e organização das equipes e sua distribuição geográfica. Um dos aspectos comuns a todas as empresas é que a gestão do portfólio de projetos de novos produtos é uma atividade intrinsecamente ligada aos departamentos de engenharia de produto, desenvolvimento de produtos ou P\&D. Em todas as empresas há inúmeras evidências de que esses departamentos são responsáveis por uma grande parte dos processos necessários, tais como registrar e organizar idéias para novos produtos, levantar informações sobre o mercado, estimativa de investimentos, informações sobre a concorrência, tecnologias necessárias, competências disponíveis e uma série outras informações. Além disso, essas equipes são as grandes responsáveis pelo acompanhamento dos projetos e pela atualização das informações nas revisões do portfólio.

É importante conhecer e analisar a estrutura de desenvolvimento de produtos, uma vez que um dos focos da gestão do portfólio de projetos de novos produtos também está no gerenciamento dos projetos individuais, para que essa estrutura consiga efetivamente entregar projetos cuja contribuição esteja dentro do que foi estabelecido pelo plano estratégico da empresa (PMI, 2006b). Outro fator relevante é a presença de atividades de P\&D nas unidades fora do Brasil, pois o desenvolvimento de produtos voltados para o mercado local é fundamental para o sucesso da indústria globalizada (INNOVATION, 2007) além de influenciar o processo de gestão do portfólio de projetos da matriz brasileira. Veja no quadro seguinte a presença de fábricas e P\&D para as empresas:

\begin{tabular}{|c|c|}
\hline EMPRESA & PRESENÇA NO EXTERIOR \\
\hline ALFA & Todas as fábricas possuem equipes de P\&D locais \\
\hline BETA & Fábrica e P\&D nos EUA \\
\hline TIGRE & Apenas fábricas no Paraguai, Chile, Argentina e Bolívia \\
\hline WEG & Argentina, Portugal $(P \& D)$, México $(P \& D)$ e China \\
\hline
\end{tabular}

Quadro 10 - Unidades das empresas no exterior 


\subsubsection{ALFA}

A engenharia de desenvolvimento de produtos na ALFA é responsável pelo desenvolvimento de produtos e pela pesquisa e desenvolvimento de novas tecnologias. Essa engenharia é conhecida internamente também como o grupo de Gestão de Tecnologia de Produtos e Processos (GTPP), que é dividido em uma área para desenvolvimento de novas tecnologias e em outra para desenvolvimento de produtos usando as tecnologias já dominadas. O GTPP possui também uma grande rede de cooperação, formada por clientes, empresas parceiras, fornecedores, universidade e institutos de pesquisa ao redor do mundo, especialmente nos EUA e na Europa.

A engenharia conta com um grupo de cerca de 450 pessoas no mundo todo (272 no Brasil, 73 na Eslováquia, 69 na China, 39 na Itália e 2 nos EUA). Há projetos de novos produtos executados fora do Brasil, porém a maioria é desenvolvida na matriz brasileira. Todos os projetos são discutidos pelos gestores do Brasil, que consolidam o planejamento tecnológico englobando os projetos a serem desenvolvidos nas unidades do exterior. A engenharia da matriz brasileira passou por um processo de reorganização, iniciado em 1996, quando a empresa decidiu desenvolver novos produtos usando uma estrutura orientada por projetos. Equipes de especialistas foram organizadas, criando os Grupos de Tecnologias (GT’s), que abrangem áreas como: sistemas térmicos; sistemas acústicos; projeto estrutural; química e materiais; projeto de motores elétricos; projeto de controles eletrônicos. A empresa também desenvolveu, ao longo de sua existência, uma série de competências que contribuem na sustentação de sua vantagem competitiva, em acordo com o que afirmam Prahalad e Hamel (1990),

Em 1996 os gestores da equipe de engenharia sentiam uma enorme dificuldade quando um projeto pequeno entrava na mesma fila de um projeto grande. Era comum que um projeto pequeno, de uma semana, demorasse meses para ser completado. Então, a reorganização do departamento criou metodologias e equipes diferentes para lidar com cada tipo de projeto. Os projetos pequenos seguem o seu fluxo e têm uma equipe dedicada, assim como os projetos maiores seguem o seu fluxo específico, maior e mais complexo, com equipes alocadas temporariamente do pool de recursos do departamento. O processo de reestruturação do departamento de desenvolvimento contou com a participação de uma consultoria externa ${ }^{1}$. A equipe que estava reestruturando o processo de desenvolvimento de produtos apresentava as

\footnotetext{
${ }^{1}$ A equipe de consultoria não foi divulgada a pedido da empresa.
} 
idéias e o pessoal da consultoria externa analisava de forma crítica. Esse fato evidencia um dos diferenciais dessa empresa, também observado na WEG, de buscar de forma intensiva o conhecimento acadêmico e combiná-lo ao conhecimento e à experiência de seu pessoal para aprimorar o processo de desenvolvimento de produtos e também a sua estrutura organizacional. Antes dessa reorganização, que foi concluída em 1997, a engenharia de desenvolvimento trabalhava por departamentos, em uma estrutura funcional (SLACK et al., 2002). Havia um departamento de elétrica, um departamento de mecânica, um departamento de engenharia de produtos e um departamento de engenharia industrial. Após a reorganização, foram criados cargos de gestores dos projetos: há um gestor para os projetos grandes, médios e pequenos, um gestor para os projetos de desenvolvimento tecnológico e um gestor de recursos da engenharia.

Em 2003 a ALFA passou a administrar os projetos médios por meio de um escritório de gestão de projetos (PMO) simples, como contou um dos entrevistados. Esse PMO passou a olhar os múltiplos projetos, com foco principalmente no controle dos prazos. Esse PMO funciona de uma forma bastante similar ao sugerido pelo PMI (2004), atuando como suporte ao diversos grupos na gestão dos projetos. Há aproximadamente dois anos esse grupo utiliza um software chamado PRIMAVERA ${ }^{1}$ para gestão dos projetos médios. Em 2006 foi criado um PMO do GTPP que acumulou as funções do PMO de projetos médios e estendeu as atividades também para os projetos grandes. Foi criado um sistema de indicadores para todas as dimensões dos projetos e do portfólio. Esses indicadores são atualizados pela equipe do PMO, que propõe e executam projetos de melhoria nos processos de gestão. Porém, as equipes dos projetos grandes e projetos de desenvolvimento tecnológico (DT) ainda usam ferramentas isoladas (cronogramas, planilhas etc). Em 2007 o PMO de projetos médios foi unificado ao de projetos grandes e começou a conscientizar a alta gestão da necessidade da gestão holística dos projetos buscando a melhoria de performance do portfólio, como vantagem competitiva, com o objetivo de se transformar em um PMO de resultados, não só para metodologia e apoio na gestão dos projetos. "Além de buscar a conformidade com os manuais (PMO), a idéia é fomentar a melhoria na performance, aplicando a teoria das restrições", como afirma um dos entrevistados.

Com relação à organização de equipes por especialidades e por tipos de projetos, a ALFA apresenta uma estrutura próxima àquela apresentada como ideal por Clark e Wheelwright (1992) e bem próxima à estrutura encontrada na WEG Além disso, a iniciativa

\footnotetext{
1 PRIMAVERA é um software especializado para gestão de projetos e portfólio de projetos. Fonte: http://www.primavera.com
} 
de criar um PMO permite a introdução de novos processos de gestão ao mesmo tempo em que aperfeiçoa aqueles já existentes. Isso posiciona essa empresa como uma das mais maduras em termos de gestão do portfólio de projetos.

\subsubsection{BETA}

A Divisão de Desenvolvimento é responsável pelo projeto e desenvolvimento de produtos e serviços, relacionados às áreas eletro-eletrônica, mecânica e de software. A empresa como um todo possui uma estrutura hierárquica com poucos níveis, o que se reflete na Divisão de Desenvolvimento: há um Diretor, Gerentes de Grupo, Coordenadores de Projetos, Desenvolvedores e Pessoal de Apoio. A Divisão de Desenvolvimento possui dois grandes grupos: Desenvolvimento Eletrônico e Desenvolvimento Mecânico. Cada um desses grupos, por sua vez é subdividido em grupos menores, com especialidades e funções específicas. A divisão conta com cerca de 150 profissionais, entre engenheiros, técnicos e pessoal administrativo, recebendo cerca de 6\% do faturamento para suas atividades de pesquisa, desenvolvimento de novos produtos e manutenção dos produtos existentes.

O Diretor da Divisão de Desenvolvimento é o grande responsável pela elaboração, aprovação, manutenção e revisão do Plano Geral de Desenvolvimento (PGD) junto à diretoria e ao conselho de acionistas. Além disso, ele é o responsável direto pelo gerenciamento do portfólio de projetos e pela execução dos projetos que a empresa decide empreender, ou em outras palavras, ele é o principal responsável pela execução do PGD. Ele realiza a inserção dos novos projetos e juntamente com os gerentes de grupo de coordenadores de projetos planeja sua execução. Ele é o responsável por autorizar o inicio de um projeto, seja ele do PGD ou de uma Ordem de Serviço (OS) especial.

Os Gerentes de Grupo são responsáveis diretos pela gestão dos recursos humanos e pelo gerenciamento dos projetos em conjunto com o diretor, além de outras funções administrativas. É importante ressaltar que todos os gerentes de grupo têm formação técnica e também atuam como desenvolvedores de produtos. Na figura seguinte pode-se ver a estrutura atual com os grupos da Divisão de Desenvolvimento: 


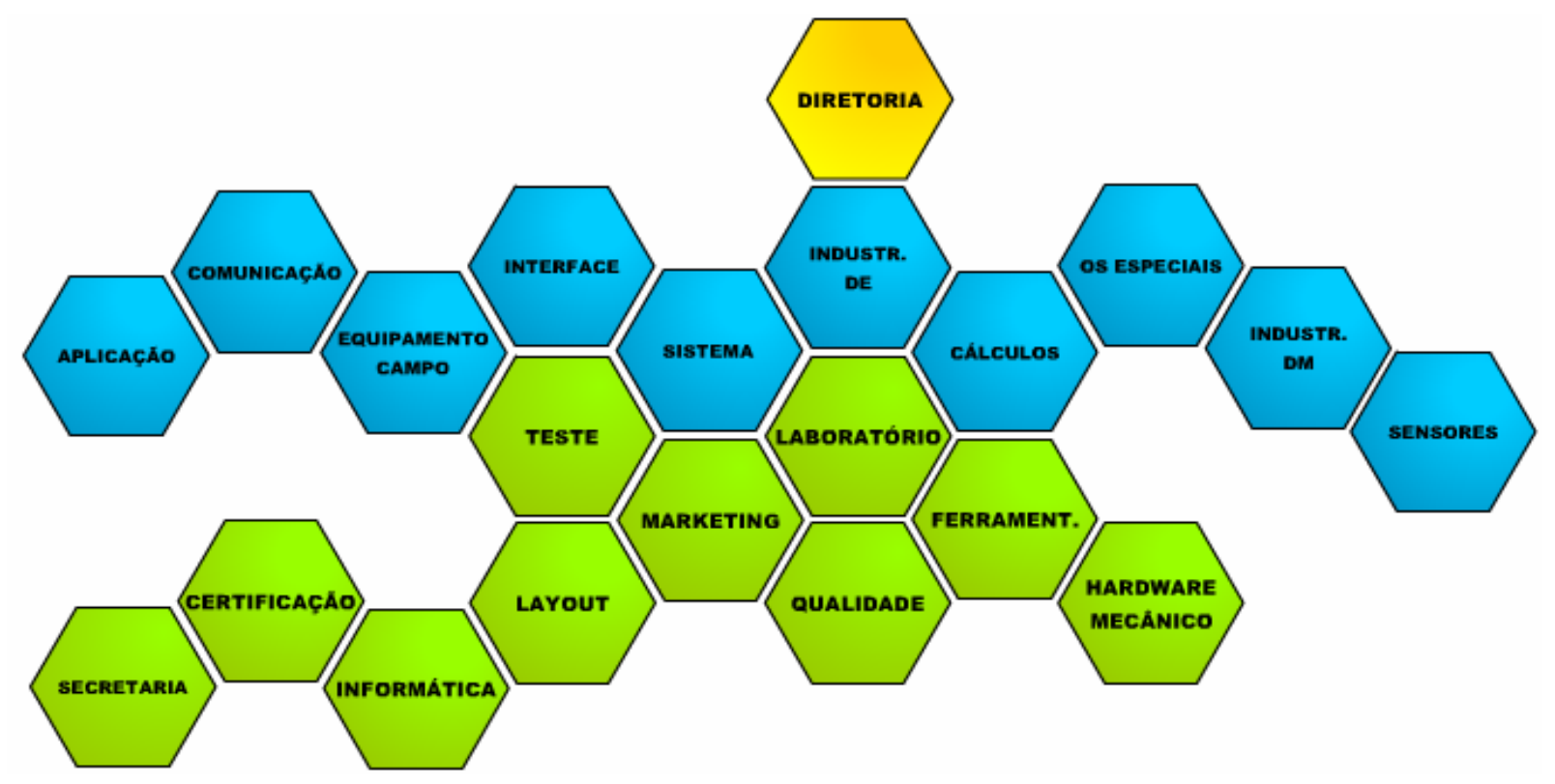

Figura 14 - Grupos da Divisão de Desenvolvimento da BETA

Por outro lado, o responsável direto pela execução de um projeto é o coordenador de projetos. Ele é freqüentemente chamado de "pai" do projeto. Na Intranet da empresa há uma lista com os nomes de todos os coordenadores de projetos, para que qualquer pessoa da empresa possa entrar em contato com ele caso deseje falar sobre um dos projetos que ele coordena. O coordenador de projetos deve cuidar para que o projeto atinja todos os seus objetivos, durante e após a fase de projeto, quando o projeto é industrializado e se torna um produto de linha.

A estrutura de desenvolvimento de produtos presente na empresa remonta às antigas estruturas funcionais, onde cada grupo é responsável por uma especialidade, sendo coordenado por um gerente. Esse tipo de estrutura, apesar de bastante flexível com relação ao compartilhamento de recursos, não oferece um suporte adequado para o desenvolvimento de projetos co diferentes complexidades e durações. Essa organização é bastante semelhante àquela encontrada na ALFA antes de 1997 e que foi modificada justamente por não responder de forma adequada às necessidades de crescimento da empresa. Devido à diversidade de produtos desenvolvidos pela BETA (equipamentos de diversos tipos e softwares), os projetos variam bastante em complexidade, prazo e tamanho das equipes envolvidas. Assim, a estrutura atual parece não atender de forma adequada às atividades dos projetos. É possível afirmar que a empresa ainda sofre de sérios problemas com relação ao atendimento de prazos, o que já foi objeto de estudo em recente pesquisa em sua divisão de desenvolvimento. Internamente, há um consenso de que os desenvolvedores são sobrecarregados com um 
número excessivo de projetos. Segundo Cooper et al. (1997), a ausência de foco na estratégia da empresa causa um número excessivo de projetos, pulverizando os recursos do departamento, o que, por sua vez, causa atrasos na execução e degradação da qualidade dos projetos. Esse fato já foi alvo de pesquisa recente na empresa que comprovou a ausência de uma gestão mais eficiente do portfólio de projetos que acabou levando a uma sobrecarga dos desenvolvedores, agravada pelo estresse e frustração pela baixa performance do processo.

Comparada às outras empresas dessa pesquisa a BETA é a única que possui unidades nos EUA, sendo uma fábrica e uma unidade de P\&D. A unidade de P\&D é totalmente independente da divisão de desenvolvimento da matriz brasileira. Ela possui um portfólio de projetos e produtos que é administrado de forma independente. Quando há projetos em conjunto, as duas unidades se comportam como se fossem empresas diferentes.

\subsubsection{TIGRE}

O departamento de Pesquisa, Desenvolvimento e Engenharia (PD\&E) da TIGRE é responsável pelas atividades de $\mathrm{P} \& \mathrm{D}$ e também responde pela Engenharia, que agrupa as atividades de suporte à fabricação dos produtos. O departamento possui uma estrutura matricial, onde cada projeto tem um líder. A partir de 1998, com um novo plano estratégico, o PD\&E foi recriado a fim de permitir a criação das condições necessárias para que a empresa se mantivesse competitiva. A partir de 2002, o PD\&E foi novamente reestruturado, buscando idéias de novos produtos de forma mais intensiva, iniciando parcerias e cooperação com universidades e reorganizando totalmente seu processo de inovação e gestão de projetos. $\mathrm{O}$ departamento de PD\&E é formado pelo Desenvolvimento de Produtos, pela a Engenharia de Qualidade e pelo Centro de Desenvolvimento de Moldes, centralizados na matriz em Joinville. Além da equipe interna, mantêm convênios e parcerias com a Universidade Federal de Santa Catarina, Unicamp, Universidade Federal de São Carlos, Universidade Federal do Paraná e Escola Politécnica da USP. Suas atividades são reconhecidas internacionalmente, tendo recebido o prêmio FINEP de Inovação Tecnológica por diversas vezes. Em 2007, a TIGRE recebeu R\$ 9 milhões da Financiadora de Estudos e Projetos (FINEP) para investir em projetos de desenvolvimento tecnológico nos setores de construção civil, infra-estrutura e irrigação. Somente na área de $\mathrm{P} \& \mathrm{D}$, a empresa aloca cerca de 82 profissionais, dos quais 22 mestres e pós-graduados. No total, são aproximadamente 3,5 mil itens na linha de produtos. A empresa obteve 102 patentes nos últimos 10 anos, no Brasil e no exterior. Graças à iniciativa 
de diversificação agressiva a empresa lançou dezenas ${ }^{1}$ de novos produtos voltados para a melhoria e a inovação no processo de condução de água, esgoto e eletricidade. Esses novos projetos são fruto de um novo conceito de trabalho: a Engenharia Simultânea. Esse conceito propõe uma seqüência de ações integradas no desenvolvimento de cada solução (FINEP, 2008).

Apesar da TIGRE apresentar um expressivo número de novos produtos lançados nos últimos anos, muito maior do que as outras empresas analisadas nessa pesquisa, a maior parte dos produtos se trata de melhorias em produtos já existentes ou de novas aplicações para o PVC, tais como forros, esquadrias, móveis e utensílios domésticos. Poucos produtos foram realmente inovadores, porém, há alguns exemplos. Um deles é um armário para banheiro que teve as dimensões de suas paredes calculadas usando uma tecnologia de simulação de estruturas, chamada de elementos finitos. Por meio dessa tecnologia, desenvolvida em parceira com uma universidade, foi possível identificar as áreas onde o material sofria menor esforço e então reduzir a dimensão do PVC, economizando plástico e assim reduzindo o custo do produto. A estrutura de desenvolvimento de produtos da TIGRE é semelhante à organização da BETA, onde há grupos especialistas que são compartilhados pelos diversos projetos. Da mesma forma, essa estrutura apresenta problemas quando os projetos possuem características, complexidades ou prazos de execução muito diferentes. Porém, diferentemente da BETA, os produtos desenvolvidos pela TIGRE são em sua maioria derivados de PVC, ou seja, são produtos cujo processo de desenvolvimento é previsível e bastante conhecido pela empresa.

A TIGRE é a única empresa dessa pesquisa que não possui atividades de P\&D fora do Brasil. Segundo os entrevistados, as necessidades de cada mercado são discutidas nas filiais do exterior e trazidas para a matriz, onde os produtos são então adaptados ou desenvolvidos. Porém, a principal motivação para o desenvolvimento de produtos voltados especificamente para os mercados do exterior é a questão de normas técnicas. Um dos entrevistados citou o exemplo dos tubos de PVC. Cada país onde a empresa atua possui suas próprias normas técnicas que definem dimensões, cores, materiais que podem ou não ser utilizados, dentre outras características. Assim, o envolvimento das filiais do exterior no desenvolvimento de produtos e também na gestão do portfólio de projetos tem sido limitado apenas às adaptações necessárias para superar as barreiras técnico-comerciais de cada país. A internacionalização teve como principal objetivo até o momento o acesso a novos mercados, a melhoria da sua

\footnotetext{
${ }^{1} \mathrm{O}$ número exato de novos produtos lançados foi omitido devido ao sigilo solicitado pela empresa.
} 
capacidade da exportação e a adaptação dos produtos à demanda de mercados específicos em acordo com Vieira e Zilbovicius (2005), Arruda, Goulart e Brasil (1994) e Innovation (2007).

\subsubsection{WEG}

O Comitê Científico e Tecnológico é responsável, entre outras atividades, por auxiliar a diretoria a traçar os planos estratégicos em termos de novas tecnologias e novos produtos. Para isso, mantém estreita relação com universidades e centros de pesquisa ao redor do mundo. Esse comitê é composto por representantes de vários departamentos, sobretudo dos departamentos de Engenharia de Produtos e de P\&D, que podem ser considerados como os centros nervosos da gestão do portfólio.

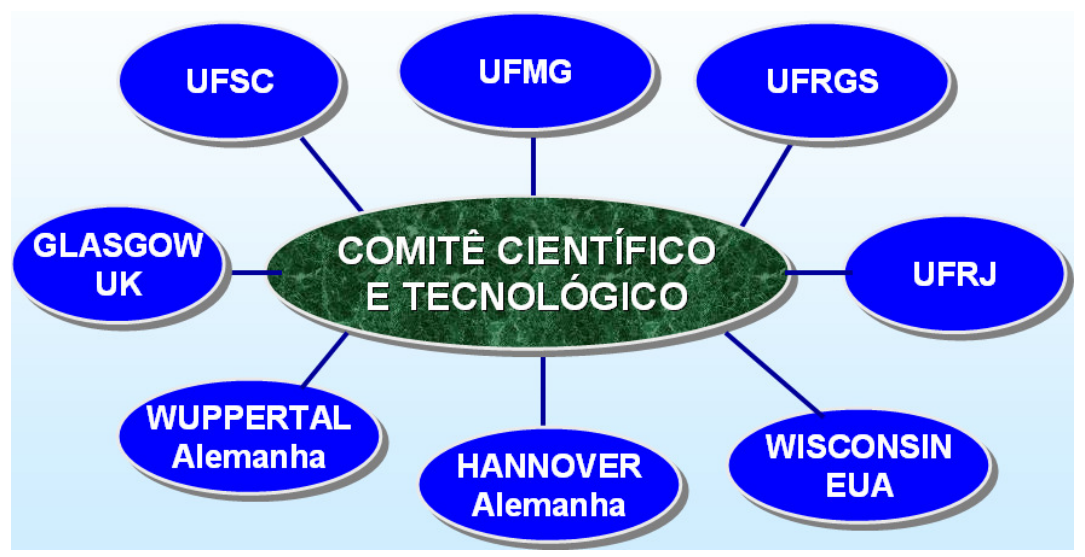

Figura 15 - Relacionamentos externos do comitê científico e tecnológico da WEG ${ }^{\mathbf{1}}$

O departamento de engenharia de produtos é um dos grandes responsáveis pelas inovações incrementais em processos e produtos, de acordo com a classificação sugerida pela OECD (2005). Esse departamento conta atualmente com cerca de 100 pessoas no Brasil e está estruturado em três equipes: Desenvolvimento, Aplicação e Administração de Produtos. A equipe de Desenvolvimento tem o trabalho de criar novos produtos utilizando tecnologias já dominadas. Seu foco também está no acompanhamento das vendas, de grandes clientes, na análise de mercado e em projetos mais elaborados e complexos, com um horizonte entre 1 e 2 anos. Já a equipe de Aplicação adapta produtos de prateleira, trabalhando em projetos com duração não maior que algumas semanas. A última equipe é chamada de Administração de Produtos, que atende exclusivamente a linha de frente da produção, fazendo pequenas

\footnotetext{
${ }^{1}$ Informação da palestra "Como Realizar a Gestão da Inovação nas Empresas" apresentada na UNINDUS em Curitiba, PR, por Sebastião Lauro Nau, gerente de P\&D da WEG Motores, em 27 de Novembro de 2007.
} 
alterações (cor, embalagem, furações) e tratando problemas de assistência técnica da fábrica e problemas de produção, ou seja, atua basicamente nos processos produtivos. Esta equipe executa mais ou menos 1000 pequenas alterações em projetos por mês. Segundo um dos gerentes entrevistados, há cerca de 76 projetos em andamento, sendo que 4 desses são projetos de novos produtos. Em termos de novos conceitos há 12 projetos, sendo que alguns são conceitos aplicados a um produto completamente novo e outros a uma parte de um produto já estabelecido.

A Engenharia desenvolveu um software chamado "Configurador de Vendas", embutindo toda a sua experiência em fornecer diferentes combinações de produtos. Com esse configurador, que consegue gerar milhões de combinações diferentes para os vendedores, essa equipe cria mil estruturas de produto (lista técnica com os componentes do motor) por mês, a partir dos pedidos do pessoal de vendas. Os vendedores configuram o produto e o sistema gera automaticamente a lista técnica, que vai direto para a fábrica, sem passar pela engenharia. O produto que o vendedor não consegue configurar com esse software, isto é, que exige uma solução especial, vai então para a engenharia. Pequenas adaptações são realizadas pela equipe de administração de produtos. Se, por outro lado, são grandes alterações, que necessitam de uma análise mais elaborada, vai para a área de aplicação. Quando é identificada uma grande oportunidade de venda ou mesmo de uma nova linha de produtos, combinando características e tecnologias já dominadas, aí o projeto é direcionado para a equipe de desenvolvimento.

Em especial, merece nota o fato de que o grupo de aplicação trabalha junto ao cliente, desenvolvendo o produto, realizando visitas técnicas, desenvolvendo protótipos, sugerindo mudanças na máquina do cliente e no produto final onde o motor será aplicado. O contato com o cliente permite que a empresa conheça as demandas com bastante antecedência, por trabalharem diretamente com pessoas também das áreas de engenharia e desenvolvimento dos seus clientes. Isso torna a equipe de aplicação, dentro da engenharia de produtos, extremamente importante na captação de idéias e de novas oportunidades.

Por sua vez, o departamento de P\&D é o grande responsável pelas inovações de maior impacto em processos e em produtos, basicamente desenvolvendo novos conceitos e novas tecnologias (OECD, 2005). Nesse departamento há o que se chama de sistema de P\&D da WEG, apoiado em três ações básicas: pesquisa, retenção e disseminação. A primeira ação é a pesquisa, para entender profundamente o comportamento dos produtos atuais e futuros nas mais variadas aplicações, para descobrir novos materiais e técnicas de projeto, para melhorar os produtos atuais e desenvolver produtos e processos mais competitivos. A segunda ação é a 
retenção do conhecimento gerado. Artigos são escritos para perpetuar o conhecimento adquirido enquanto ao mesmo tempo criam a base técnica para futuras pesquisas. Por fim, a disseminação significa a intenção deliberada de compartilhar o conhecimento por meio de cursos, palestras, seminários e encontros técnicos com o objetivo de treinar as pessoas cujas atividades estejam relacionadas à pesquisa. As três ações têm a premissa básica de criar e compartilhar o conhecimento dentro da WEG para que outras pessoas possam se tornar especialistas individuais no assunto e também multiplicar ainda mais esse conhecimento. $\mathrm{O}$ objetivo é que a empresa continue a oferecer produtos competitivos, com alta qualidade e alta performance ${ }^{1}$.

O departamento de P\&D é responsável por três grandes atividades. A primeira delas é o desenvolvimento de novos materiais, principalmente em conjunto com os fornecedores, tais como materiais magnéticos, materiais isolantes e materiais condutivos. Outra grande atividade é aperfeiçoar e otimizar os produtos atuais, cujo objetivo é reduzir custos e aumentar o desempenho dos produtos. Essa atividade, junto com a engenharia, engloba diversos projetos de inovações incrementais. A terceira atividade é o desenvolvimento de novas tecnologias. Nos ramos de otimização e desenvolvimento de produtos com novas tecnologias há uma forte cooperação com a área de engenharia de produto. Todo produto conceitualmente novo nasce primeiro no departamento de $\mathrm{P} \& \mathrm{D}$. Depois que a concepção está pronta é que o P\&D passa para a engenharia e o projeto do produto é detalhado.

Há diversas equipes de especialistas no $\mathrm{P} \& \mathrm{D}$, englobando especialistas em ruídos e vibrações, em motores com ímãs permanentes, em técnicas de análise por elementos finitos, em motores monofásicos, em otimização de produtos, engenharia de materiais, dentre outras. Todos esses times concentram recursos especializados que são compartilhados no desenvolvimento dos inúmeros projetos simultâneos que a empresa decide investir. Assim como no departamento de engenharia, para cada projeto sempre há um coordenador, um líder. Além da função administrativa, o coordenador trabalha intensivamente no desenvolvimento do produto, executando trabalhos técnicos. Dessa forma, os departamentos de engenharia de produto e $\mathrm{P} \& \mathrm{D}$ possuem estruturas que desempenham um papel fundamental na elaboração do planejamento estratégico de novas tecnologias e produtos, na captação de novas idéias, na análise e seleção dessas idéias e obviamente no desenvolvimento dos projetos até o lançamento de produtos comerciais.

\footnotetext{
${ }^{1}$ Informação da palestra "Como Realizar a Gestão da Inovação nas Empresas" apresentada na UNINDUS em Curitiba, PR, por Sebastião Lauro Nau, gerente de P\&D da WEG Motores, em 27 de Novembro de 2007.
} 
A organização da engenharia e do P\&D dessa empresa é bastante similar à organização encontrada na ALFA. Há uma equipe para desenvolvimento de novas tecnologias e outra para desenvolvimento de produtos com tecnologias dominadas. Além disso, na WEG existe um sistema descentralizado de desenvolvimento de produtos: cada empresa da Divisão de Motores, no Brasil e no exterior, tem uma estrutura própria de Engenharia e de P\&D. Porém, todas são subordinadas ao Programa de Desenvolvimento Tecnológico (PDT) que é centralizado pelo departamento de $\mathrm{P} \& \mathrm{D}$ da matriz em Jaraguá do Sul. Esse programa é elaborado anualmente com a participação de todas as empresas do grupo.

Outra característica da WEG, similar à empresa ALFA, é que algumas unidades estrangeiras também desenvolvem produtos. Tanto a sua unidade de Portugal quanto a unidade do México possuem equipes de $\mathrm{P} \& \mathrm{D}$ e de engenharia de produtos, aptas ao desenvolvimento de novos produtos em suas áreas específicas. Porém, não há sobreposição com a matriz e cada unidade desenvolve produtos de acordo com suas competências e com as necessidades de seus mercados alvo. Por exemplo, a unidade de Portugal fabrica motores à prova de explosão, voltados para aplicações em áreas com atmosferas explosivas. A decisão de desenvolver um novo tipo de motor à prova de explosão é tomada em conjunto com a matriz brasileira. Porém, as atividades de desenvolvimento acontecem na unidade portuguesa. Nesse sentido, as unidades interferem diretamente na gestão do portfólio de projetos da matriz, apresentando propostas de novas idéias, participando da avaliação e seleção dos projetos e contribuindo com recursos para o desenvolvimento dos novos produtos.

De acordo com Vieira e Zilbovicius (2005) empresas como a WEG buscam a internacionalização para conquistar novos mercados, aumentando seu volume e melhorando sua eficiência industrial. Além de para adaptar produtos à demanda de mercados específicos. Além de adaptar produtos, como no caso da TIGRE, a WEG procura desenvolver produtos voltados para seus mercados externos. Nessa mesma perspectiva, Arruda, Goulart e Brasil (1994) avaliam o processo de internacionalização a partir de quatro concepções distintas: (a) internacionalização como evolução da capacidade da exportação; (b) internacionalização como uma busca para a competitividade tecnológica; (c) internacionalização como conseqüência da habilidade de agregar sócios; e (d) internacionalização como conseqüência de exposição internacional. Pelo perfil traçado nessa pesquisa para as empresas que farão parte do estudo multicaso entende-se que a maioria, senão todas, se enquadram primeira concepção. 


\subsubsection{Resumo comparativo da estrutura para desenvolvimento de produtos}

No quadro seguinte são resumidas as principais características das equipes de desenvolvimento de produtos, com relação à unidade departamental responsável pelos processos de gestão do portfólio, divisão das equipes, estrutura organizacional, distribuição geográfica dos projetos e integração com as unidades de P\&D no exterior.

\begin{tabular}{|c|c|c|c|c|}
\hline CARACTERISTICAS & ALFA & BETA & TIGRE & WEG \\
\hline $\begin{array}{l}\text { Departamento responsável } \\
\text { pelos processos de gestão } \\
\text { do portfólio }\end{array}$ & $\begin{array}{l}\text { Grupo de gestão } \\
\text { de tecnologias, } \\
\text { produtos e } \\
\text { processos }\end{array}$ & $\begin{array}{l}\text { Divisão de } \\
\text { desenvolvimento }\end{array}$ & $\begin{array}{l}\text { Departamento de } \\
\text { PD\&E }\end{array}$ & $\begin{array}{l}\text { Departamento de } \\
\text { Engenharia de } \\
\text { Produtos e } \\
\text { departamento de } \\
\text { P\&D }\end{array}$ \\
\hline Divisão das equipes & $\begin{array}{l}\text { Grupos } \\
\text { especialistas } \\
\text { divididos por tipo } \\
\text { de projeto }\end{array}$ & $\begin{array}{l}\text { Grupos } \\
\text { especialistas } \\
\text { compartilhados } \\
\text { entre os projetos. } \\
\text { Elevado número } \\
\text { de projetos } \\
\text { simultâneos }\end{array}$ & $\begin{array}{l}\text { Grupos } \\
\text { especialistas } \\
\text { compartilhados } \\
\text { entre os projetos. } \\
\text { Poucos projetos } \\
\text { simultâneos }\end{array}$ & $\begin{array}{l}\text { Grupos especialistas } \\
\text { divididos por tipo de } \\
\text { projeto }\end{array}$ \\
\hline Estrutura organizacional & Projetos & Hipertexto & Projetos & Projetos \\
\hline $\begin{array}{l}\text { Distribuição geográfica dos } \\
\text { projetos }\end{array}$ & $\begin{array}{l}\text { Distribuído para } \\
\text { novos produtos e } \\
\text { centralizado na } \\
\text { matriz para novas } \\
\text { tecnologias }\end{array}$ & $\begin{array}{l}\text { Centralizado na } \\
\text { matriz }\end{array}$ & $\begin{array}{l}\text { Centralizado na } \\
\text { matriz }\end{array}$ & $\begin{array}{l}\text { Distribuído entre a } \\
\text { matriz e as unidades } \\
\text { do exterior de acordo } \\
\text { com as competências } \\
\text { técnicas }\end{array}$ \\
\hline $\begin{array}{l}\text { Integração com as unidades } \\
\text { de P\&D no exterior }\end{array}$ & $\begin{array}{l}\text { Forte integração, } \\
\text { desenvolvimento } \\
\text { conjunto } \\
\text { orientado pela } \\
\text { matriz brasileira }\end{array}$ & Independentes & $\begin{array}{l}\text { Não possui P\&D } \\
\text { fora do Brasil }\end{array}$ & $\begin{array}{l}\text { Forte integração, } \\
\text { desenvolvimento } \\
\text { conjunto orientado } \\
\text { pela matriz brasileira }\end{array}$ \\
\hline
\end{tabular}

Quadro 11 - Resumo comparativo da estrutura de desenvolvimento de produtos

\subsection{PLANEJAMENTO ESTRATÉGICO DE NOVOS PRODUTOS E TECNOLOGIAS}

Após a apresentação da estrutura de desenvolvimento de produtos década empresa, esta seção descreve as principais nuances do planejamento estratégico na ALFA, BETA, TIGRE e WEG. No planejamento estratégico e tecnológico é onde a gestão do portfólio efetivamente nasce. A gestão do portfólio de projetos de novos produtos faz sentido enquanto ferramenta gerencial que contribui para atingir os objetivos estratégicos da empresa (PMI, 2006b). Portanto, para analisar as práticas gerenciais dessas empresas com relação a esse tipo de gestão, é necessário conhecer seu planejamento estratégico para novos produtos e tecnologias. Esse planejamento e os mecanismos pelos quais ele é elaborado influenciam diretamente em todas as fases da GPPNP, uma vez que contém elementos direcionadores, 
valores, visões e missões que funcionam como parâmetros para a analisem, seleção, priorização, adiamento e cancelamento de projetos.

O portfólio reflete os investimentos realizados ou planejados pela empresa, que devem estar alinhados com os seus objetivos estratégicos. Durante o processo de GPPNP, as prioridades são identificadas, decisões de investimento são tomadas e recursos são alocados. Assim, em consonância com Cooper e Edgett (2003), a composição do portfólio reflete concretamente onde a empresa está investindo seus recursos. O planejamento estratégico da empresas inclui os direcionadores utilizados em todas as fases do desenvolvimento dos novos produtos, especialmente nas fases de captação de idéias e na definição de objetivos estratégicos. O planejamento estratégico da empresa normalmente é desdobrado em planos para desenvolvimento de produtos e novas tecnologias. Esse desdobramento muitas vezes é responsabilidade das engenharias de produtos e/ou dos departamentos de P\&D.

\subsubsection{ALFA}

É possível afirmar que a característica principal da gestão do portfólio na ALFA é seu planejamento tecnológico, um desdobramento do planejamento estratégico da empresa que engloba tanto os projetos de pesquisa em novas tecnologias quanto os projetos de novos produtos. Esse plano é fundamentado em pesquisas de mercado, abrangendo não somente seus clientes principais no mundo todo, mas também seus parceiros tecnológicos. Em termos de volume de negócios, uma das áreas onde a empresa atua representa a maior parte do seu faturamento. Porém, de acordo com um dos gerentes entrevistados, uma das estratégias da empresa é crescer em outras áreas e mudar esse perfil:

Atualmente quem responde pela demanda são grandes clientes. Eles
demandam muito do departamento de desenvolvimento, e a empresa acaba
dedicando muitos recursos a eles. Então, à medida que você divide um
pouco, mesmo que saindo do mesmo pool de recursos, começa a ficar mais
equilibrado.

A estratégia de inovação tecnológica da empresa pode ser resumida nas seguintes definições:

a. Inovação: processo de transformação de uma invenção em produto comercial

b. Invenção: resultado de um processo de descoberta, de princípios técnicos novos, potencialmente abertos para exploração comercial, mas não necessariamente realizada. 
c. Sustentabilidade: assegurar o sucesso do negócio em longo prazo, aliando valores econômicos, sociais e ambientais.

d. Tecnologia: o desenvolvimento tecnológico é um componente fundamental no ciclo de inovação de um grande número de empresas.

A ALFA se apóia em um ciclo de inovação e geração de valor para assegurar a sustentabilidade da empresa. Para inovar, a empresa acredita que é preciso integrar competências, gestão, cooperação tecnológica e financiamento. Esse ciclo é orientado pela missão de oferecer soluções inovadoras para uma melhor qualidade de vida, com a visão de ser o fornecedor preferencial de soluções em todos os mercados onde atua. Esses objetivos são suportados pela meta de investimento de até $3 \%$ do faturamento anual em P\&D. Mesmo com o cenário econômico turbulento das últimas décadas, o investimento constante em P\&D garantiu à empresa sua permanência na liderança tecnológica do setor. Com isso, a proporção do faturamento com produtos lançados a menos de 4 anos, cuja meta é de $50 \%$, está atualmente em $69 \%$.

Uma das características do planejamento tecnológico é o desenvolvimento contínuo de novas plataformas de produtos. A partir das novas plataformas, a empresa desenvolve modelos que são aperfeiçoados continuamente, reduzindo custos e melhorando performance, até atingir os limites da tecnologia, quando então entra em cena uma nova tecnologia desenvolvida para substituí-la. Assim, a empresa consegue aliar excelência operacional com liderança tecnológica, atingindo um de seus objetivos estratégicos que é a sustentabilidade. $\mathrm{O}$ planejamento tecnológico considerado nesse estudo compreende um conjunto de projetos para o período de 2007 a 2010. Esse plano foi concluído em dezembro de 2006 e divulgado em fevereiro de 2007. O ciclo de planejamento e revisão do portfólio foi iniciado no mês de setembro de 2006, com reuniões em todas as plantas ao redor do mundo. Esse planejamento para os grandes projetos é revisado anualmente e nessa reunião anual, os projetos em andamento são avaliados e novas propostas de projetos são analisadas. Segundo um dos entrevistados:

Nessa reunião tomamos algumas decisões importantes sobre 3 ou 4 projetos cuja fase de concepção termina em Junho ou Julho. Então, nós faremos a avaliação e se eles andarem como nos imaginamos aqui, vão em frente. Se não andarem, teremos que rever todo o pacote de projetos, porque é possível que tenhamos alguns problemas. Lembra que eu falei que tinha um projeto que se não for para frente, dois outros precisam ir para não ficarmos desguarnecidos no mercado? Então, Julho para nós é um momento importante, de revisão desses 3 ou 4 projetos que são bastante importantes. 
A engenharia é responsável por desdobrar os objetivos estratégicos da empresa em objetivos para os novos projetos. Uma característica do planejamento tecnológico é estabelecer planos complementares para o desenvolvimento de projetos mais longos e complexos, os chamados projetos de desenvolvimento tecnológico, e também para os demais projetos de desenvolvimento de produto, usando tecnologias já maduras ou dominadas.

A ALFA se tornou conhecida ao longo dos anos, dentre outras razões, por sua liderança tecnológica no setor e por sua excelência industrial. Sempre foi uma empresa orientada pela tecnologia do setor, muito mais criando do que seguindo demandas. Buscando complementar seu planejamento tecnológico, a empresa contratou em 2004 uma consultoria no exterior para auxiliar no desenvolvimento de um novo plano estratégico, por meio de uma metodologia elaborada para cobrir os seguintes tópicos: possíveis cenários do negócio; estudo Delphi ${ }^{1}$ para prospecção de novas tecnologias; análise de mercado; opções tecnológicas atuais e futuras; descrição dos projetos; análise estratégica do portfólio de projetos. O plano estratégico de tecnologia baseado nos resultados dessa consultoria, para o período de 2004 a 2014, foi fundamentado em uma pesquisa cujo objetivo principal era desenvolver um profundo conhecimento das tendências internas e externas do negócio, permitindo traduzir sua visão em um plano concreto para desenvolvimento tecnológico, assim como iniciar um processo de planejamento estratégico anual para tecnologia. Como diretrizes estratégicas foram definidos quatro objetivos ${ }^{2}$ usados para o alinhamento dos projetos de novas tecnologias e novos produtos.

Segundo um dos entrevistados, foram realizadas cerca de 50 entrevistas com empresas localizadas nos EUA, Europa e Ásia. Essas entrevistas foram estruturadas em torno de um questionário incitando os respondentes a externarem suas opiniões sobre como seria seu mercado em 2014. A partir dessas entrevistas, foram construídos diversos cenários futuros, baseados nas demandas da sociedade e dos seus clientes, nos mercados, nos concorrentes e no ambiente. Cada cenário partia de um diagnóstico do ambiente e da seleção de fatores chave para sua descrição. Foram então elaborados prognósticos para esses fatores, cuja projeção e consistência foi cuidadosamente analisada. A partir desses prognósticos foram desenvolvidos os cenários futuros para desenvolvimento de novas tecnologias e produtos.

\footnotetext{
${ }^{1}$ O método Delphi é um método sistemático e iterativo para obter previsões de diversos especialistas sobre um determinado assunto. Os especialistas selecionados respondem a questionários em duas ou mais rodadas. Ao final de cada rodada, um facilitador fornece a todos um resumo anônimo com todas as respostas, encorajando os participantes do estudo a revisarem suas respostas. De acordo com o método, após um certo número de rodadas as respostas devem convergir para uma opinião consensual. Fonte: http://en.wikipedia.org/wiki/En/delphi.

${ }^{2}$ Os objetivos não foram divulgados a pedido a empresa por serem confidenciais.
} 
De todos os cenários possíveis que foram exercitados durante o planejamento, alguns foram selecionados de acordo com os objetivos de longo prazo da empresa para cada mercado alvo. Por meio da análise conjunta de todos esses cenários selecionados, a empresa traçou um plano de direcionamento corporativo e tecnológico, partindo de sua posição atual em termos de estratégia, visão e tecnologias disponíveis, chegando até sua posição futura projetada para 2014. Essa projeção futura incluiu as tecnologias, competências e soluções necessárias para abranger os cenários selecionados para o plano estratégico. A partir desse estudo ${ }^{1}$ foram identificadas novas tecnologias com aplicação potencial em seus produtos.

Assim como em inúmeras outras empresas, na ALFA não há uma fonte única de idéias: elas podem vir de várias frentes, como marketing, vendas, engenharia ou da fábrica. A engenharia tem a característica de ter um bom entendimento do mercado, pois seu pessoal vai muito ao campo e visita anualmente todos os principais clientes ao redor do mundo, de onde surgem muitas idéias. Há também a Assistência Técnica dentro da engenharia, que também visita os clientes três, quatro vezes por ano. Então a engenharia também tem o papel de trazer muitas idéias e oportunidades. Há também idéias vindas da fábrica, como melhorias em processos e mudanças mais significativas, que muitas vezes requerem uma participação maior da engenharia na forma de um projeto. Os fornecedores também participam, dependendo do escopo da mudança. Entretanto, pode-se dizer que as grandes fontes de novas idéias são os departamentos de engenharia e de marketing.

$\mathrm{Na}$ intranet da ALFA existe um sistema que permite a qualquer funcionário deixar uma sugestão para um novo produto ou processo, seja para a criação de uma novidade ou para melhoria em algo já existente. Essas idéias são encaminhadas para análise dos gestores das áreas correspondentes e eventualmente, após um primeiro filtro, elas podem vir a ser analisadas posteriormente para se transformarem em novos projetos. Atualmente algumas dezenas $^{2}$ de projetos de novos produtos estão em andamento, consumindo a maior parte do investimento total em P\&D. Dessa forma, fica evidente que a ALFA investe considerável quantidade de seus recursos em projetos de grande impacto, com grande risco e grande potencial de resultados.

\footnotetext{
${ }^{1} \mathrm{O}$ estudo Delphi realizado na ALFA partiu da identificação de profissionais especializados nas diversas áreas de interesse, no mundo todo. Esses especialistas foram localizados tanto em empresas clientes e parceiras quanto em institutos de pesquisa e universidades. A partir daí, uma primeira versão do questionário foi elaborada pelo time de P\&D da ALFA, e foi então distribuída para essa lista de especialistas. A abordagem para motivar os especialistas a responderem o questionário foi que ele receberia ao final os resultados compilados da pesquisa. Isso resultou em um alto índice de retorno dos questionários.

${ }^{2}$ A quantidade foi omitida a pedido da empresa.
} 


\subsubsection{BETA}

O principal mecanismo de planejamento tecnológico da empresa é o seu Plano Geral de Desenvolvimento (PGD), que consiste em uma lista com todos os projetos previstos para um período de 5 a 10 anos. "Novas idéias de produtos não nos faltam, pelo contrário, temos até em excesso", comenta um dos coordenadores de projetos entrevistados. Em função da origem da empresa (os fundadores são todos engenheiros e técnicos) e dos mercados nos quais atua, é uma empresa nitidamente orientada por tecnologia. Não há um mecanismo formal ou único para a coleta e registro de idéias para novos produtos, como um banco de idéias ou algo similar. Também não há uma pessoa ou um grupo responsável pelo processo de coleta e registro de novas idéias. Porém, há evidências de que os seguintes departamentos contribuem na geração de idéias para novos produtos: assistência técnica; controle de qualidade da produção; engenharia de aplicações nacional, internacional; divisão de marketing; conselho de acionistas; diretoria.

As áreas que tem contato direto com os clientes são as principais responsáveis pela captação das novas idéias: vendedores, assistência técnica, engenharia de aplicações e marketing. Ainda que os desenvolvedores contribuam muito com inovações e idéias inspiradas na evolução tecnológica do setor e em estudo de problemas dos clientes, é possível afirmar que os engenheiros de desenvolvimento da BETA, em comparação com as outras empresas desse estudo, não têm uma relação tão forte de proximidade com seus usuários finais e acabam percebendo a maioria das necessidades dos clientes apenas de forma indireta por meio de outros departamentos. Muitas oportunidades também são capturadas por meio de decisões do conselho de acionistas e da própria diretoria, ambos compostos por profissionais com décadas de experiência no setor. Todas essas idéias são avaliadas e as aquelas tidas como oportunidades reais de negócio pelo Conselho de Acionistas são incluídas no Plano Geral de Desenvolvimento (PGD).

O PGD é uma extensa lista de projetos, incluindo os projetos de novos produtos e projetos de melhorias. Com relação aos novos projetos, o PGD representa a intenção da empresa em desenvolver tais produtos, sendo, portanto, uma lista de idéias já filtradas e selecionadas pelos Acionistas e pelos Diretores, contendo apenas aquelas que representam oportunidades reais de negócio para a empresa no horizonte de tempo abrangido pelo plano. Não há o compromisso de que todos os projetos listados no PGD serão efetivamente desenvolvidos. O PGD na BETA marca, de forma geral, o início de um novo ciclo de negócio do ponto de vista da gestão do portfólio de projetos. Nesse aspecto, essa empresa trabalha 
com um horizonte de planejamento tecnológico maior que das demais empresas dessa pesquisa. O PGD representa as idéias mais significativas colhidas no ecossistema da empresa e tem um horizonte médio de 7 anos.

O PGD 1 foi iniciado em 1981, com o objetivo principal de projetar uma linha de instrumentos para controle de processos. Seus principais projetos tratavam de transmissores de pressão e temperatura, largamente utilizados na indústria em geral. O PGD 2, por sua vez, foi iniciado em 1986 e visava a expansão no mercado internacional. O sucesso desse plano se deveu muito ao desenvolvimento de novos produtos tecnologicamente atualizados e, ao mesmo tempo, comercialmente competitivos. O PGD 3, iniciado em 1994, tinha o objetivo de desenvolver uma tecnologia estratégica.

Atualmente a empresa está trabalhando no PGD 4, que foi lançado oficialmente em 2004. Projetos que já estavam em andamento, mas que não eram parte do PGD 3, foram incluídos então nesse novo plano tecnológico. A justificativa para isso é que, ao longo do tempo, os clientes demandam projetos especiais que eventualmente são agregados à linha de produtos da empresa, integrando dessa forma o novo PGD. Ao mesmo tempo, projetos previstos no PGD sofrem revisões ou até mesmo são descartados em face das mudanças nos cenários interno e externo da empresa. O PDG representa, em última análise, o plano estratégico para novos produtos e tecnologias. A partir dele a empresa aloca seus recursos, planeja contratação de pessoal, compra de novas tecnologias, contratação de serviços terceirizados, treinamentos, compra de equipamentos e uma série de outros investimentos. Nesse cenário, a Divisão de Desenvolvimento da BETA é a principal responsável pela elaboração e execução do plano estratégico para novos produtos e tecnologias.

\subsubsection{TIGRE}

Quando de um novo projeto, o departamento de PD\&E analisa inicialmente em que linha de negócios o novo projeto se insere. Segundo o seu gerente, há três linhas principais de negócio: sonho da casa própria, infra-estrutura e agricultura. $\mathrm{Na}$ linha do sonho da casa própria, a missão é dominar todo o ciclo da água para uso urbano: "Atuamos desde a captação até o tratamento, distribuição, instalação residencial e comercial, coleta de esgoto, captação do esgoto até estação de tratamento e o retorno da água tratada à natureza”. Assim, a empresa procura oferecer soluções que racionalizam ao máximo a construção residencial envolvendo 
água, esgoto, eletricidade, telefonia e gás. Em infra-estrutura, a empresa oferece produtos para redes coletoras e de tratamento de água e esgoto, de serviços de gás, de telecomunicações e de energia. Os produtos para esse mercado são baseados em soluções sustentáveis, que reduzam perdas, sejam estanques, tenham o processo de instalação simplificado e diminuam a necessidade de interferências urbanas. $\mathrm{Na}$ área de Agricultura, há diversos produtos especiais voltados para irrigação, poços, drenagem, enfim, para o domínio do ciclo da água em áreas rurais. A água é um insumo essencial para a moderna agricultura. Hoje, 70\% do total da água doce utilizada em todo o mundo destina-se à produção de alimentos. Por isso o crescimento da produtividade está cada vez mais associado à disponibilidade de água na hora, no local e na quantidade certos. Além dessas três áreas, a TIGRE também desenvolve produtos especiais, para uso na indústria, por exemplo, tubos e conexões especiais para mineração. Essa linha também tem a função de servir como laboratório para novos materiais com tecnologias avançadas.

A TIGRE possui um conjunto de valores que direcionam suas atividades diárias e também seu planejamento estratégico. Compreendendo que as atitudes diárias são responsáveis pelo seu sucesso, os valores mais significativos estão relacionados com ações e com as relações pessoais. A cooperação, a transparência, o fazer acontecer, a inovação, o foco estratégico e finalmente o comportamento do prestador de serviço. Além dos seus valores, a empresa tem três diretrizes estratégicas: desenvolvimento de novos negócios, novos produtos e novos mercados. A empresa tenta criar o seu "oceano azul", como afirma, em entrevista, o gerente de PD\&E: "Tentamos fugir da briga por preços e diferenciar nossos produtos, oferecendo maior valor agregado". Para isso, o planejamento estratégico elaborado e aprovado pela diretoria é o subsídio para o planejamento de novos produtos que é implementado pelo departamento de Pesquisa e Desenvolvimento. Esse planejamento deve conter o retrato mais fiel possível das necessidades dos mercados onde a empresa atua. Para isso, a captação de novas idéias e o contato com esses mercados é fundamental. Com este propósito há uma estrutura com diversos canais e um processo bastante estruturado.

O processo de captação de novas idéias começa com a análise de campo, que aponta uma necessidade do mercado, para só então passar à realização do projeto e seu desenvolvimento. O processo de inovação permeia todos os ambientes da empresa, por intermédio de uma política de oferta de soluções completas. Para garantir o estado de arte da tecnologia em gestão, processos e sistemas, a empresa mantém parcerias com universidades, instituições de pesquisa e fornecedores no Brasil e no exterior. A inovação é o resultado da 
cultura empresarial e da estrutura de PD\&E, que faz a diferença quando agrega valor para o consumidor (TIGRE, 2008).

O pessoal de PD\&E dedica grande parte de seu tempo em atividades de campo, que envolvem entrevistas com instaladores, filmagem de pedreiros e observação de usuários dos produtos. A equipe tem atualmente mais de 40 horas de vídeos resultados dessas atividades externas. "É um excelente laboratório para descobertas de novas oportunidades de negócios", afirma um dos entrevistados. Além do trabalho de campo, há um serviço por telefone chamado Tele Tigre, que recebe um grande número de ligações por mês com sugestões de melhorias e de novos produtos. Além disso, a engenharia está continuamente promovendo workshops e fóruns de discussão com instaladores, arquitetos, engenheiros e outros parceiros, para prospectar idéias e obter avaliações sobre os produtos atuais. Segundo o gerente de P\&D:

O pessoal de P\&D precisa entender o problema do usuário e daí buscar novas tecnologias e novos produtos. Nosso pessoal está em contato constante com universidades (centros de excelência em mecânica, materiais, hidráulica). Também participamos de feiras nacionais e internacionais, para termos contato com outros especialistas. Contratamos também um serviço de vigilância tecnológica, fornecido por um escritório de patentes. Esse serviço nos fornece um clipping nacional e internacional periódico.

Os parceiros comerciais abrangem mais de 50 mil pontos-de-venda, com suporte da equipe de campo e de serviços exclusivos via telefone e internet, garantindo o monitoramento das relações comerciais. Entre os profissionais que são atendidos pela equipe de assistência técnica encontram-se projetistas, engenheiros, arquitetos e instaladores. As construtoras e empreiteiras também recebem atendimento especializado em campo.

Dentre as diversas iniciativas para aproximar-se do mercado e conhecer seus clientes e suas necessidades, destaca-se a "Universidade TIGRE", que parte da premissa de que o conhecimento é o único diferencial competitivo sustentável em longo prazo. Ciente desse desafio, a empresa mantém um modelo inovador de gestão do conhecimento que possibilita interações constantes com o mercado, buscando entender, satisfazer e antecipar as expectativas do consumidor. Ela é pioneira no uso de tecnologias que permitem simultaneamente capacitar e estreitar relacionamentos com os funcionários e os principais parceiros. Com modernos recursos de comunicação interativa à distância, os programas de qualificação alcançam diariamente milhares de profissionais em mais de 110 pontos remotos (TIGRE, 2008). 


\subsubsection{WEG}

O planejamento estratégico da WEG, usado como referência para esse estudo, compreende o período de 2006 a 2010. Ele segue os direcionadores fundamentais da empresa, que são sua política da qualidade e sua carta de compromissos. A partir do planejamento estratégico é que se desdobram todas as ações de engenharia de produtos e P\&D e que se estabelecem os objetivos para os novos produtos. Um dos pilares do plano estratégico é a política da qualidade, que estabelece o fornecimento de produtos e serviços com qualidade autêntica, ou seja, que satisfaçam as necessidades dos clientes ao menor custo possível, apoiada nos seguintes princípios (WEG, 2007):

a. Atender bem os clientes, oferecendo produtos e serviços que satisfaçam suas necessidades.

b. Dar respostas rápidas e profundas a consultas e reclamações dos clientes e cumprir os prazos prometidos.

c. Treinar e motivar os seus colaboradores para melhor desempenhar suas funções e dar oportunidade a todos para progredirem na Empresa.

d. Adotar métodos de trabalho simples, eficientes e procurar aperfeiçoá-los continuamente.

e. Fazer certo desde a primeira vez, eliminando o desperdício de tempo e material, contribuindo para a redução dos custos e aumento da rentabilidade.

f. Adotar postura preventiva, buscando sempre eliminar as causas dos problemas.

g. Tratar os fornecedores como parceiros, contribuindo inclusive no desenvolvimento de seus padrões de qualidade.

h. Melhorar a qualidade de vida, mantendo um ambiente de trabalho limpo, ordenado e seguro, preservando o meio ambiente e os recursos naturais.

Além da política da qualidade, a carta de compromissos também direciona decisões e ações, definindo orientações estratégicas mais básicas, com as quais o portfólio de projetos de novos produtos deve estar alinhado (WEG, 2007):

a. Clientes: agregar valor ao cliente por meio do fornecimento de produtos e serviços competitivos mundialmente.

b. Acionistas: criar valor para os acionistas proporcionando rentabilidade superior ao custo do capital investido.

c. Colaboradores: motivar nossos colaboradores e criar oportunidades de desenvolvimento pessoal e profissional. 
d. Fornecedores: considerar os fornecedores como parceiros de negócios.

e. Comunidade: ser uma empresa ética e socialmente responsável.

O planejamento estratégico para novos produtos e novas tecnologias não é elaborado somente pela diretoria e possui também a contribuição dos gerentes e líderes de equipes, como afirma um dos entrevistados: "O que fica no planejamento estratégico, de certo modo, já é também uma visão nossa sobre aquele produto ou aquele mercado. E na diretoria eles não têm bola de cristal, eles têm que ser auxiliados por alguém”. Dentre as inúmeras comissões interdepartamentais que existem na WEG, há a Comissão de Portfólio, responsável por organizar as informações sobre as propostas para projetos de novas tecnologias e produtos, discutir essas propostas em vários níveis, elaborar uma lista pré-selecionada de projetos e submetê-la à aprovação da diretoria. Essa comissão é formada por membros de diversos departamentos e participa desde a coleta e filtro das informações, passando pela aprovação dos projetos pela diretoria, até o acompanhamento e revisão periódica do portfólio de projetos. Porém, a comissão de portfólio por si só não é suficiente para coletar todas as informações necessárias e elaborar propostas de projeto adequadas para auxiliar na tomada de decisão da diretoria.

Há algum tempo vem sendo estudada a criação de cargos específicos para auxiliar a comissão de portfólio nessa tarefa. Esses cargos seriam ocupados por pessoas com nível gerencial, com alta experiência na área de engenharia, treinados também na área de vendas e marketing, que fariam a ligação entre as áreas de vendas, marketing e engenharia, como elo de ligação com o mercado. Essa função foi dividida em duas áreas: mercado de produtos NEMA $^{1}$ e mercado de produtos IEC. Então seus responsáveis devem ter profundo conhecimento das normas e do mercado e relacionar-se com a área de vendas, uma vez que irão avaliar a rentabilidade dos produtos, e se a linha está com dificuldades concretas de venda ou não, além de buscar informações junto à área de vendas, aos demais gerentes, coletando e organizando essas informações para apresentá-las na comissão de portfólio. $\mathrm{O}$ principal objetivo com isso é aperfeiçoar o processo de gestão do portfólio de projetos de novos produtos. A criação desses "gerentes de portfólio" foi uma forma que a WEG encontrou para tentar priorizar melhor e formalizar esse processo dentro da engenharia de produto. A quantidade de informações que vêm dos mercados, dado o crescimento da empresa, tem tornado esse processo muito turbulento para a engenharia e espera-se com isso

\footnotetext{
${ }^{1}$ NEMA e IEC são normas técnicas que definem especificações de motores elétricos. A norma IEC é mais voltada para a Europa enquanto a NEMA é voltada para o mercado Norte Americano. Fonte: http://en.wikipedia.org/wiki/Electric_motor.
} 
filtrar mais as necessidades dos clientes, facilitando o fluxo de informações entre todas as áreas envolvidas.

Para a WEG, uma das fases mais críticas no processo de gestão do portfólio de projetos de novos produtos é a captação de novas idéias e a organização dessas informações em propostas claras de novos projetos: "Os projetos que não conseguimos adequar, ou ajustar, ou oferecer naquele momento por ser algo difícil ou que não exista dentro da empresa, nós colocamos em uma poupança", relata um dos gerentes da engenharia. Essa poupança de idéias consiste em uma lista de possíveis projetos de novos produtos ou novos processos, que é constantemente atualizada e revisada e, eventualmente, as idéias com maior potencial são mais detalhadas e se tornam propostas formais de projetos. Uma das várias fontes para captação de novas idéias é a constante comparação com os concorrentes, procurando avaliar se a concorrência oferta produtos que a empresa ainda não tem, para então lançar uma nova linha. Outra possibilidade é sair na frente em alguma tecnologia, liderar tecnologicamente alguma linha de produtos. Mesmo que isso represente em algum momento a necessidade de um único cliente, sempre é realizada uma análise de potencial, que pode levar o projeto a se tornar um produto de linha. Outra forma é a partir de uma solicitação da diretoria, como conta um dos gerentes entrevistados:

Esse é o exemplo do motor com ímãs permanentes que a empresa lançou na feira de Hannover, na Alemanha. Foi um pedido da diretoria. Inicialmente, nós fomos ao cliente propor esse motor. Nós queríamos desenvolver. Então não houve uma demanda prévia do cliente. Depois que a empresa começou a oferecer o produto, aí sim um cliente se interessou em testar.

O exemplo anterior ilustra como a WEG trabalha constantemente investigando seus mercados potenciais, seja para lançar novas linhas de produtos, seja para renovar e modificar produtos existentes. Muitas vezes, a percepção dos gestores sobre determinados mercados, mesmo que não seja embasada em números e análises quantitativas, leva a empresa a investir em novos projetos. Essa prática de tomada de decisão baseada em informações qualitativas é recorrente no processo de gestão de projetos de novos produtos. Porém, é preciso salientar que a forte cultura de decisão coletiva, baseada em suas comissões de funcionários, colabora para que o conhecimento sobre o assunto seja compartilhado e a decisão seja tomada em uma base coletiva e mais madura.

A inovação muitas vezes não acontece no produto em si, mas em sua aplicação, como relata um dos entrevistados: "Nós temos então os motores com ímãs permanentes para aplicação industrial, para lavadoras de roupas, para esteira ergométrica, motores com partida direto pela rede, que é um motor que não precisa de inversor". Existem também novos 
conceitos do motor atual para lavadora de roupa tipo tanquinho e um novo conceito de um motor pequeno para ventilação. Outra idéia que está em desenvolvimento pelo $\mathrm{P} \& \mathrm{D}$ em conjunto com a Engenharia é o uso de plástico na parte estrutural do motor ao invés de alumínio e ferro fundido. "Nós temos um novo sistema de ventilação interna, um defletor de ar interno, para poder reduzir a temperatura dos motores, nós temos novos mancais que estão sendo desenvolvidos, são partes do motor”. Há uma forma clara e sistemática para coletar e registrar as idéias para novos produtos. Porém, como aponta Cooper et al (1997), é preciso muita cautela para que não haja uma quantidade excessiva de informações que possam sobrecarregar as fases seguintes, de análise e seleção dos projetos. Isso também é um problema enfrentado pela WEG, como conta um dos gerentes:

Sempre que alguém via a um cliente volta cheio de idéias. Porém, essas idéias têm de ser filtradas, reavaliadas, têm que ter números de potencial de mercado. É preciso avaliar o risco. Por isso estamos criando mecanismos de filtro, relacionados às comissões e aos gerentes de portfólio.

Nesse aspecto, as práticas observadas nas WEG estão alinhadas com o que sugere Cooper et al. (1997). A predisposição para ignorar uma idéia, que a princípio soa como uma boa oportunidade de negócio, evita que a empresa perca o foco e que acabe por iniciar muitos projetos de pouca importância. Os recursos da engenharia e do $\mathrm{P} \& \mathrm{D}$ são aproveitados de forma mais eficiente dessa forma. Esses autores também afirmam que a criação dos filtros para seleção das idéias, como relatam os entrevistados, cria condições para que a empresa invista em projetos com maior potencial de retorno, mais alinhados com o planejamento estratégico da empresa. Porém, não fica evidente que e empresa defina critérios comuns para todos os projetos. É mais provável que esses critérios variem de área para área, dependendo também do projeto e da área que o solicita. Uma vez que os mecanismos de filtro citados pelos entrevistados usualmente levam em conta apenas as características individuais dos projetos, os gerentes instintivamente tendem a tomar decisões na direção que é mais benéfica para sua área. Um gerente forte pode ter a aprovação de mais idéias, mas a organização pode ser penalizada pelo atraso produzido em outros projetos do portfólio (FRICKE; SHENBAR, 2000). Todas as empresas demonstraram ter consciência desse problema e implementar mecanismos para tentar evitá-lo, como, por exemplo, a análise conjunta de todos os projetos e os filtros em comissões com representantes de várias áreas da empresa. Porém, na ALFA, na WEG e na BETA, há casos de projetos com elevada importância estratégica que são avaliados e acompanhados individualmente. Ficou claro que ALFA, WEG e TIGRE empreendem um enorme esforço na captação de idéias, para que as fases seguintes de avaliação e seleção dos 
projetos sejam facilitadas. Apenas na BETA não está evidente que haja um esforço coordenado para captação e filtro de idéias para os novos produtos, indicando que a empresa ainda se encontra em um estágio anterior na maturidade da gestão do portfólio.

\subsubsection{Resumo comparativo do planejamento estratégico}

Do ponto de vista da gestão do portfólio de projetos o planejamento estratégico deve fornecer as diretrizes para que as diversas áreas da empresa possam propor novas idéias e estabelecer critérios para filtrar essas idéias e considerar apenas àquelas que oferecem oportunidades de ganho real. Dessa forma, é fundamental que a empresa faça um planejamento de longo prazo, definido objetivos estratégicos claros que sejam transmitidos e compreendidos por toda a empresa. O quadro seguinte compara os objetivos estratégicos identificados para as empresas:

\begin{tabular}{|c|c|l|l|}
\hline EMPRESA & HORIZONTE & \multicolumn{1}{|c|}{ OBJETIVOS $^{1}$} & \multicolumn{1}{|c|}{ NOVAS IDÉIIAS } \\
\hline ALFA & 4 anos & $\begin{array}{l}\text { Desenvolvimento tecnológico, } \\
\text { crescimento e aperfeiçoamento } \\
\text { dos produtos }\end{array}$ & $\begin{array}{l}\text { Estudo Delphi, unidades do exterior, } \\
\text { forte influência dos grandes clientes, } \\
\text { engenharia interna }\end{array}$ \\
\hline BETA & 5 a 10 anos & $\begin{array}{l}\text { Acompanhar a evolução } \\
\text { tecnológica e aumentar o } \\
\text { faturamento }\end{array}$ & $\begin{array}{l}\text { Visão da diretoria, solicitações de } \\
\text { clientes, evolução tecnológica do } \\
\text { setor. Pouca contribuição das } \\
\text { unidades do exterior }\end{array}$ \\
\hline WIGRE & 4 anos & $\begin{array}{l}\text { Manter a liderança no setor, } \\
\text { aumentar o faturamento, } \\
\text { conquistar novos nichos de } \\
\text { mercado, aumentar a margem } \\
\text { de retorno }\end{array}$ & $\begin{array}{l}\text { Intensa pesquisa com clientes e } \\
\text { parceiros, propostas internas do } \\
\text { PD\&E, visão da diretoria, pressão } \\
\text { dos concorrentes. Pouca } \\
\text { contribuição das unidades do } \\
\text { exterior }\end{array}$ \\
\hline & $\begin{array}{l}\text { Conquista de novos mercados, } \\
\text { manter tecnologia de ponta, } \\
\text { aumentar o faturamento }\end{array}$ & $\begin{array}{l}\text { Análise da concorrência, engenharia } \\
\text { de produtos e P\&D, clientes e visão } \\
\text { da diretoria. Forte influência das } \\
\text { unidades do exterior }\end{array}$ \\
\hline
\end{tabular}

Quadro 12 - Resumo comparativo do planejamento estratégico

\subsection{FORMAÇÃO DO PORTFÓLIO DE PROJETOS}

Após a definição de diretrizes e objetivos estratégicos a empresa tem condições de iniciar a seleção das melhores oportunidades de negócio para compor seu portfólio de projetos. Nessa seção serão descritas as atividades principais encontradas em cada uma das

\footnotetext{
${ }^{1}$ Os objetivos estratégicos detalhados não foram divulgados a pedido das empresas.
} 
empresas. A formação do portfólio é uma etapa constituída pelos processos de categorização, avaliação, seleção, priorização e alocação de recursos entre os projetos. De acordo com o PMI (2006b), essa fase também poderá incluir atividades de balanceamento e autorização dos componentes do portfólio (projetos). O principal objetivo em um ambiente de múltiplos projetos que competem e compartilham os mesmos recursos é maximizar o sucesso global do portfólio ao invés de privilegiar o sucesso de um único projeto em particular (COOPER, 1994; COOPER et al., 1997, 2004a, 2004b, 2004c; ARCHER; GHASEMZADEH, 1999; BLAU et al., 2004).

\subsubsection{ALFA}

A ALFA ainda não possui um grupo fixo de pessoas para a gestão do portfólio, ainda que os entrevistados tenham indicado a intenção da empresa em definir uma equipe para cuidar desse tema. Apesar de já existir um PMO para alguns tipos de projetos, a gestão ainda não está totalmente integrada. Há um ciclo anual de planejamento estratégico, que ocorre em uma primeira fase em cada uma das plantas. Segundo um dos entrevistados, houve reuniões de uma semana na China, na Europa e na matriz no Brasil. Em seguida, foram discutidos os principais projetos e as principais oportunidades de todos os mercados. Várias áreas da empresa foram envolvidas: marketing, vendas, produção, engenharia, finanças. Essas informações foram consolidadas pela matriz no Brasil, que elabora o planejamento global e formou o portfólio de projetos a partir dos projetos selecionados de cada unidade.

Após as comissões de cada fábrica, incluindo as do exterior, apresentarem seus projetos já filtrados e a matriz no Brasil consolidar uma lista alinhada estrategicamente e prépriorizada pelos gerentes da área doméstica e comercial, segue-se uma reunião com o Comitê Executivo da ALFA (COMEX), onde essa lista preliminar com as propostas de projetos é discutida. O COMEX é composto pelos diretores de todas as áreas e pelo presidente. A avaliação, seleção e priorização iniciais são realizadas pelos comitês multidisciplinares de cada unidade e pelas gerências de produto, mas no COMEX é que as decisões são tomadas, utilizando as informações fornecidas nas propostas dos projetos para formação do planejamento tecnológico para o período.

O planejamento tecnológico da ALFA lista o portfólio de tecnologias onde cada uma dela inclui um conjunto de projetos. Por exemplo, motores elétricos, válvulas, rolamentos e elementos acústicos. O desenvolvimento de novos componentes ou a melhoria dos 
componentes atuais podem gerar diversos projetos dentro desse portfólio. Os resultados do estudo Delphi elaborado na fase de planejamento estratégico foram utilizados para mapear os possíveis projetos de desenvolvimento tecnológico com relação aos aspectos Atratividade e Maturidade. A atratividade foi quantificada por meio de aspectos técnicos e de mercado, tais como $^{1}$ potencial do projeto, alinhamento estratégico, vantagem competitiva, competências críticas, risco do projeto, complexidade, competências, margem de lucro, volume de mercado, vantagem competitiva, dentre outros.

A maturidade tecnológica interna foi quantificada segundo a distância das tecnologias atuais dominadas pela ALFA, o nível de competência de P\&D e a infra-estrutura apropriada. Esses fatores foram utilizados para posicionar os possíveis projetos em um gráfico de Atratividade x Maturidade. Por esse gráfico é possível observar que, de acordo com a posição dos projetos, eles são classificados em quatro categorias: monitoração de tecnologia, projetos de pesquisa, projetos de desenvolvimento tecnológico e projetos de desenvolvimento de produto. Esse último é o mais freqüente e compreende a transferência de tecnologias para os produtos. Esse gráfico representa o que a ALFA chama de Portfólio Integrado de Tecnologia. Um exemplo desse gráfico pode ser visto na figura seguinte:

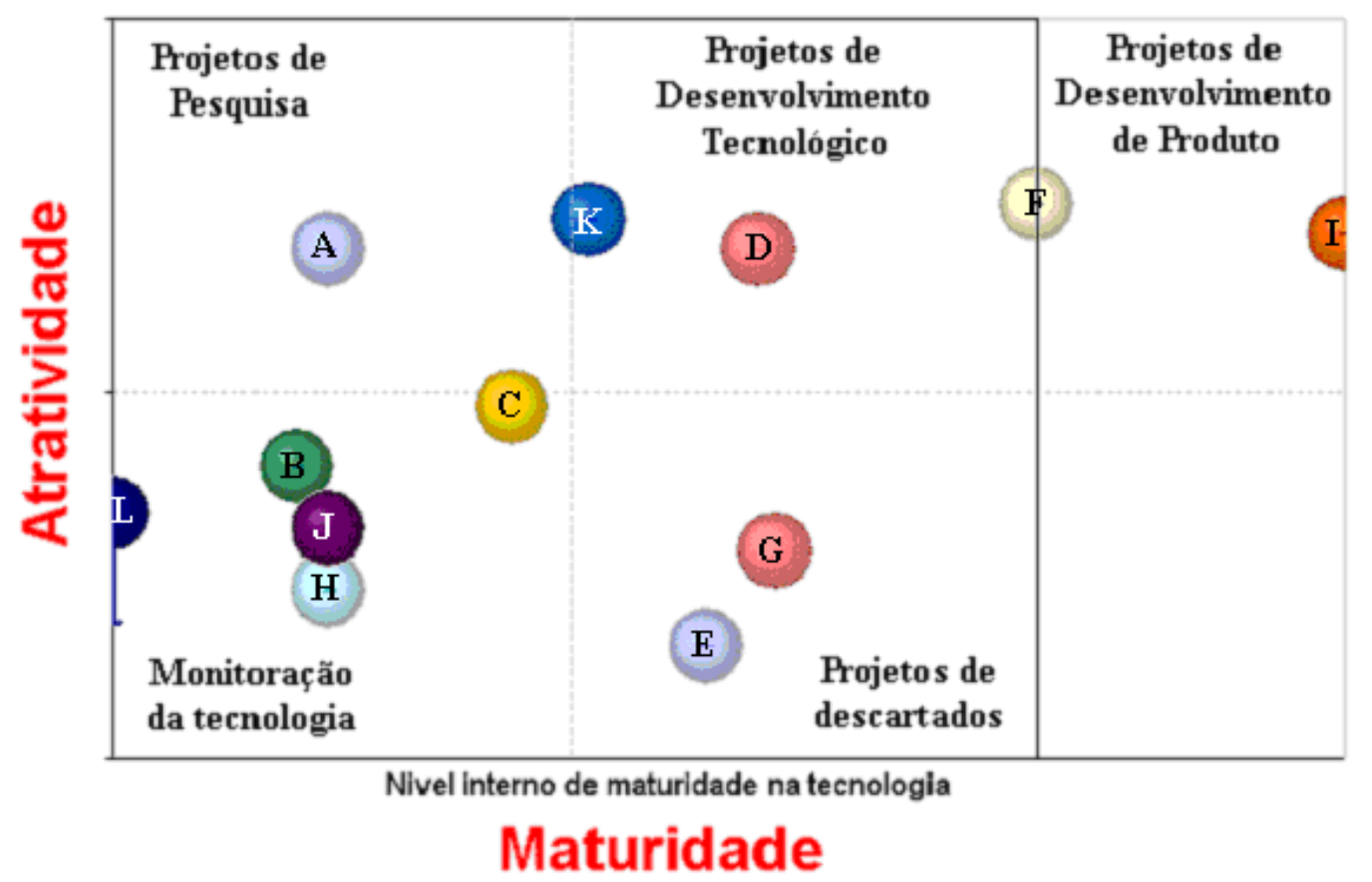

Figura 16 - Exemplo de gráfico de bolhas usado para seleção de projetos na ALFA

\footnotetext{
${ }^{1}$ A lista completa dos critérios não foi divulgada a pedido da empresa.
} 
Os projetos de desenvolvimento tecnológico (DT) ilustrados no gráfico ${ }^{1}$ anterior são projetos básicos, com maior risco, selecionados de acordo com objetivos estratégicos, tais como manter a liderança tecnológica. Normalmente envolvem cooperação com equipes externas (universidades, institutos, clientes). Demandam investimentos consideráveis para estudos e prototipagem, em um horizonte de alguns anos. Para que esses projetos possam ser comparados e analisados de forma consistente, cada um deles é descrito e classificado de acordo com três categorias:

- Projeto Solução: representam as áreas principais do negócio, possuem importância estratégica e potencial claro e, além disso, demandam esforços significativos ao mesmo tempo em que oferecem um risco elevado.

- Projetos Pilares: exigem um esforço considerável da empresa, porém apresentam um risco aceitável (moderado). São representados tipicamente pelos componentes principais dos produtos.

- Projetos Crossover (ou de tecnologias cruzadas): risco e esforço estão em níveis aceitáveis. Não são diretamente relacionados a uma solução em particular, mas permeiam diversos projetos mais complexos. Geram conhecimento que pode ser aplicado a uma variedade de produtos e plataformas.

Projetos de desenvolvimento tecnológico formam a base para os grandes projetos da ALFA (novas plataformas) e outros projetos de novos produtos que, por sua vez, são classificados em três categorias, conforme sua complexidade e nível de investimento:

a. Projetos pequenos: são alterações simples desenvolvidas a pedido de clientes, para aplicações específicas, diretamente em produtos de linha. São projetos que levam poucos dias e que vão direto para a fase de execução. Representam baixo risco e possuem uma alta demanda dos clientes.

b. Projetos médios: são projetos que envolvem alterações em componentes ou um nível de complexidade maior que dos projetos pequenos, podendo levar até algumas semanas para sua execução. Também apresentam baixo risco e são demandados por clientes.

c. Projetos grandes: são projetos que envolvem diversas concepções de componentes, resultando em um produto final totalmente novo, ou seja, em uma nova plataforma para desenvolvimento de produtos derivados. Demandam de alguns meses a alguns anos para sua conclusão. Possuem um elevado risco por estarem normalmente

\footnotetext{
${ }^{1}$ Devido ao sigilo solicitado pela empresa, os projetos tiveram seus nomes e informações numéricas omitidos.
} 
relacionados com novas tecnologias que serão incorporadas pela primeira vez em um produto final. Demandam grandes investimentos para adaptação ou montagem de novas linhas de produção.

Veja na figura seguinte como a classificação dos projetos se relaciona com as etapas do Processo de Desenvolvimento de Produtos (PDP) na ALFA:

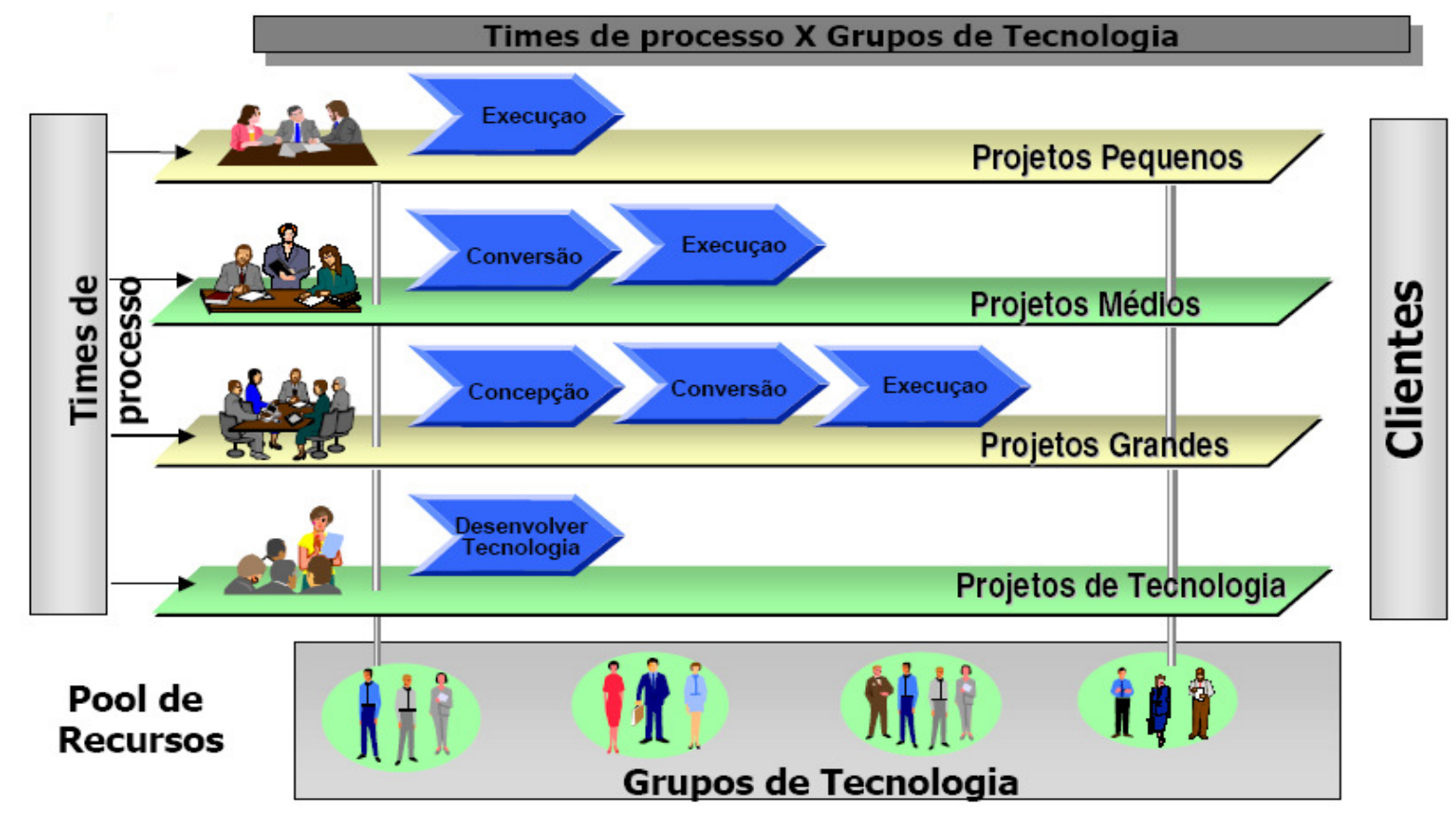

Figura 17 - Relação entre as etapas do PDP e tipos de projetos na ALFA

A divisão em etapas ilustrada na figura anterior não só facilita o processo de avaliação e seleção dos projetos, relacionado diretamente com a GPPNP, mas também o próprio desenvolvimento, na medida em que cada projeto é executado por uma equipe especializada. A metodologia utilizada para desenvolvimento de produtos, que está intimamente ligada ao processo de gestão de portfólio, divide o processo nas fases de concepção, conversão e execução. Porém, há uma atividade que precede o início do projeto, que é chamada de Ideation, que consiste de uma ou mais reuniões onde é realizada uma análise preliminar das idéias sob o ponto de vista do negócio, com uma ótica de retorno financeiro e também de tecnologia. A ALFA busca sempre um equilíbrio entre diferentes tipos de projetos na formação do seu portfólio, seja em melhorias, novas plataformas e novas tecnologias. Para aqueles projetos que passam pelo filtro inicial do Ideation e que representam oportunidades reais de negócio, é elaborado um estudo de caso, um plano de negócios com todos os fatores e análises possíveis naquele momento. Também há projetos que vem da própria diretoria. Nessa fase, são levantados os riscos técnico-comerciais do projeto, de acordo com um dos entrevistados: 
Uma idéia pode não passar da fase de Ideation em duas situações: ou é um projeto que não faz sentido sob o cunho técnico ou, mesmo que ele faça sentido tecnicamente, pode não ter mercado suficiente para justificar seu investimento. Então, ele é deixado na gaveta e a cada ciclo de revisão do portfólio ele é reavaliado.

Durante o Ideation a proposta de projeto já recebe uma prioridade inicial, apenas como orientação para a fase seguinte. Essa análise é realizada por um time formado, via de regra, por um especialista de produto, um especialista de desenvolvimento de produto, pelo menos um especialista de processos e um representante de marketing, sendo que um deles (geralmente da engenharia) fica incumbido de conduzir a avaliação e entrar em contato com as pessoas chave de processos, de produto e de marketing para detalhar melhor a idéia. Nessa fase, o projeto pode não passar e ser abandonada ou pode ficar em espera, como cita um dos entrevistados:

Estamos reavaliando agora o projeto de um produto que foi proposto há dois anos e meio. Naquela época não passou, porque não teria aceitação de mercado. Agora estamos atualizando o mesmo plano de negócios que se tornou viável.

Durante o Ideation é elaborado também um planejamento preliminar de recursos para as fases de concepção, conversão e execução. Uma peça fundamental nesse processo é o líder do projeto, que tem uma função dupla: a gestão do projeto e também a implementação, tanto da parte técnica do produto quanto do processo de fabricação. Existe um histórico com informações detalhadas sobre o desenvolvimento dos projetos porém, segundo os entrevistados, é pouco usado auxiliar nesse planejamento. Esse processo é bastante similar ao Stage-Gate de Cooper (1994). De acordo com um dos gerentes entrevistados: "É preciso sempre levar em conta na avaliação e priorização do projeto os recursos de engenharia que serão necessários, porque isso é sempre um dos gargalos do desenvolvimento. Quase sempre há menos recursos do que o necessário para desenvolver todos os projetos selecionados”, o reconhecimento dessa restrição está de acordo com o que apontam Cooper e Edgett (2003), Clark e Wheelwright (1992) e Evers (2000).

Segundo afirmaram os entrevistados, não é realizada uma análise sistemática de sinergias entre os projetos para avaliar o valor gerado pelo portfólio. Porém, segundo os entrevistados, a equipe de avaliação conhece o portfólio e procura evitar as sobreposições, processo esse que depende muito de experiência e de análise qualitativa. Esse tipo de processo é apontado por Blau et al. (2004) como uma das formas mais usadas para se avaliar a sinergia entre os projetos. Esses autores sugerem que, quando há alguma dependência entre os 
projetos, devem-se analisar as sinergias pelo menos para evitar as sobreposições mais evidentes ou ainda, buscar a maximização do retorno. É comum também haver alguma concorrência, especialmente na esfera dos projetos de desenvolvimento tecnológico. Muitas vezes é preciso escolher uma das opções ou então fundir projetos. Mas quando se trata de desenvolvimento de produtos, normalmente um projeto grande ou médio, essa sobreposição é menor, gerando pouca concorrência entres os produtos. Mas a empresa pode decidir ter um plano B e desenvolver produtos concorrentes para atuação em mercados diferentes, como um produto mais avançado para os mercados mais exigentes e um produto com uma tecnologia mais antiga, para outros mercados.

Assim que a idéia é aprovada na fase de Ideation ela passa para a fase de concepção, onde terá seu plano de negócios detalhado para uma nova rodada de avaliação. O primeiro fator a ser levado em conta na seleção ou priorização dos projetos é o retorno financeiro. Além disso, há uma avaliação de valor criado percebido pelo cliente por meio do EVA ${ }^{1}$ estimado para o projeto. Nenhum projeto começa sem que se tenha uma estimativa do retorno. Além disso, no plano de negócios é comum a presença de indicadores financeiros como o Payback e o ROI. Segundo os entrevistados, há uma tendência para que o Payback seja cada vez menor. Porém, o grande indicador utilizado para avaliação e acompanhamento do projeto antes de depois de sua finalização (produto) é o EVA® (Economic Value Added). O EVA® é monitorado ao longo do projeto em alguns casos. Em segundo lugar em termos de importância vem o Payback. Já houve tentativas de se utilizar um BSC (Balanced Score Card) adaptado à realidade do negócio da empresa, porém esse tipo de ferramenta não se mostrou adequada para a análise e priorização de projetos e não é mais utilizada. Nessa fase a idéia é aprovada por uma análise objetiva, levando em conta os objetivos do produto. Ao final dessa fase, ocorre uma nova avaliação, quando se decide se o projeto vai adiante ou não. Se ele for aprovado, começa o detalhamento, o produto entra no seu desenvolvimento propriamente dito, com prototipagem, testes etc.

O principal responsável por consolidar as informações usadas na avaliação dos projetos é o 3PM (Product, Project and Portfolio Manager). Esse profissional está ligado à diretoria, sendo responsável pela ligação com as gerências de projeto no âmbito da GPPNP. A área de engenharia, na pessoa do líder do projeto, fornece informações de retorno econômico, recursos necessários e investimentos. O líder de projeto acumula, além da função de gestão do projeto em si e da elaboração dos indicadores de gestão de projetos, prazos, impactos,

\footnotetext{
${ }^{1}$ Marca registrada da Stern Stewart \& Co.
} 
contingências, recursos, gerenciamento financeiro, também o gerenciamento do escopo técnico do projeto. Porém, para a parte técnica em si, há o apoio de um coordenador de produto, um especialista naquele tipo de produto específico. Dependendo do tamanho e da complexidade do projeto, há dois ou mais especialistas de produto e quase uma dezena de especialistas de processo. Após a elaboração do plano de negócios detalhado, o 3PM e o líder do projeto convocam uma reunião do COMEX para análise do projeto. O COMEX faz um novo filtro nos projetos apresentados, levando em conta as informações apresentadas no plano de negócios e os objetivos estratégicos da empresa. Alguns projetos são aprovados para a fase seguinte, de conversão; alguns são cancelados e para outros o comitê solicita mais informações para reavaliá-los posteriormente. A seleção e principalmente a priorização dos projetos privilegia a necessidade de atingir os objetivos estratégicos para o período planejado. Também existem dependências entre alguns projetos, por exemplo, se um projeto der certo, outros não serão desenvolvidos. Um dos entrevistados cita um exemplo:

Esse é o caso de um projeto em desenvolvimento tecnológico na Europa, onde o risco ainda é alto. Não sabemos se vai dar certo ou não, mas se der certo, é um projeto que será vencedor. Agora, se não der certo teremos que retomar os outros dois projetos que foram suspensos.

A priorização dos projetos selecionados na fase de concepção classifica os projetos em grupos: DT, G1, G2, G3. O pacote de DT (Desenvolvimento Tecnológico) procura atender os objetivos de longo prazo, para novas plataformas de produto. Os projetos do grupo G1 são os mais prioritários, considerados críticos ou que já estão em andamento e serão obrigatoriamente concluídos, tendo prioridade na alocação de recursos. Os projetos G2 têm um nível alto de prioridade. No caso dos G3 e G4, apenas serão realizados caso haja recursos disponíveis. Porém, é comum que os projetos do grupo G4 nem entrem na priorização, sendo descartados ou registrados para reavaliação futura. Atualmente, há cerca de 5 ou 6 projetos no grupo G1, 10 projetos no G2 e algumas dezenas de projetos menores no G3. A limitação de recursos para a execução dos projetos do grupo G3 é normalmente associada a pessoas.

Os projetos aprovados e priorizados após a fase de concepção passam para a fase de conversão, que é uma fase de detalhamento técnico do projeto e de desenvolvimento propriamente dito, com todo os desdobramentos em termos de alocação de recursos e entregáveis. A alocação dos recursos nos diversos grupos de tecnologia (GT) é realizada de acordo com esse detalhamento. Mesmo com todos os filtros anteriores e com o processo de avaliação e seleção em várias fases, ainda surgem mais projetos do que a empresa consegue absorver, fato apontado por Cooper et al. (1997) como uma das principais consequiências de 
falhas na gestão do portfólio de projetos, levando a uma grande concorrência interna pela utilização dos recursos. A negociação para solução desses conflitos é realizada pelos gerentes, líderes de projetos e até mesmo pelos próprios desenvolvedores. Os gerentes questionam os líderes dos GT's e discutem se o esforço previsto para cada tarefa está adequado.

Os recursos distribuídos nos GT's são compartilhados por todas as classes de projetos: DT's, grandes, médios e pequenos. O processo de alocação descrito anteriormente é válido especialmente para projetos grandes. Para projetos médios e pequenos há grupos fixos de pessoas e eventualmente algumas trabalham nos projetos grandes também, mas conceitualmente, são times de tamanho fixo. Segundo um dos entrevistados da ALFA, o fato do pool de recursos da engenharia ter um gerente dedicado a acompanhar e negociar a alocação do pessoal com todos os líderes de projeto é um fator decisivo para a alocação de recursos. Esse gerente de recursos da engenharia, juntamente com o líder do projeto e com o gerente de produto montam a equipe de cada projeto. Os especialistas de cada de GT são alocados de acordo com a necessidade e a prioridade do projeto, definidos por um acordo entre os líderes de projetos, o gerente de produto, o gerente do pool de recursos da engenharia e o gerente de desenvolvimento de produtos da engenharia. Esse grupo de gestores tem o papel de transmitir a orientação estratégica da empresa para as equipes de desenvolvimento. Ainda que os especialistas sejam compartilhados em vários projetos, há um objetivo da gerência de tentar minimizar o número de projetos onde cada pessoa trabalhará simultaneamente, o que está em consonância com Clark e Wheelwright (1992) com relação à produtividade em função do número de projetos onde o desenvolvedor trabalha simultaneamente. O gestor de projetos da ALFA explica o que ocorre na prática:

Imagine que somos dois líderes de projeto e que precisamos de $1 / 2$ especialista de motor. Então, o especialista vai trabalhar 50\% comigo e 50\% contigo. Isso é possível, mas como eu disse, procuramos evitar ao máximo, apesar de ser um problema bem real, que não podemos ignorar.

Por fim, se o projeto é aprovado ao final da fase de conversão, são disparados os elevados investimentos nas linhas de produção, nos novos postos de trabalho, nas ferramentas mecânicas, desenvolvimento de fornecedores, peças plásticas, dentre outras ações necessárias para lançar o produto no mercado e fechar o projeto. Essa fase é chamada de execução e consistem em transferir o produto do desenvolvimento para a fábrica, com todos os processo produtivos prontos. Assim que o produto começa a ser fabricado acontece o fechamento do projeto, uma fase de avaliação dos resultados preliminares do produto, envolvendo inclusivo a 
disseminação do conhecimento criado pelo projeto. As fases descritas anteriormente estão ilustradas na figura seguinte:

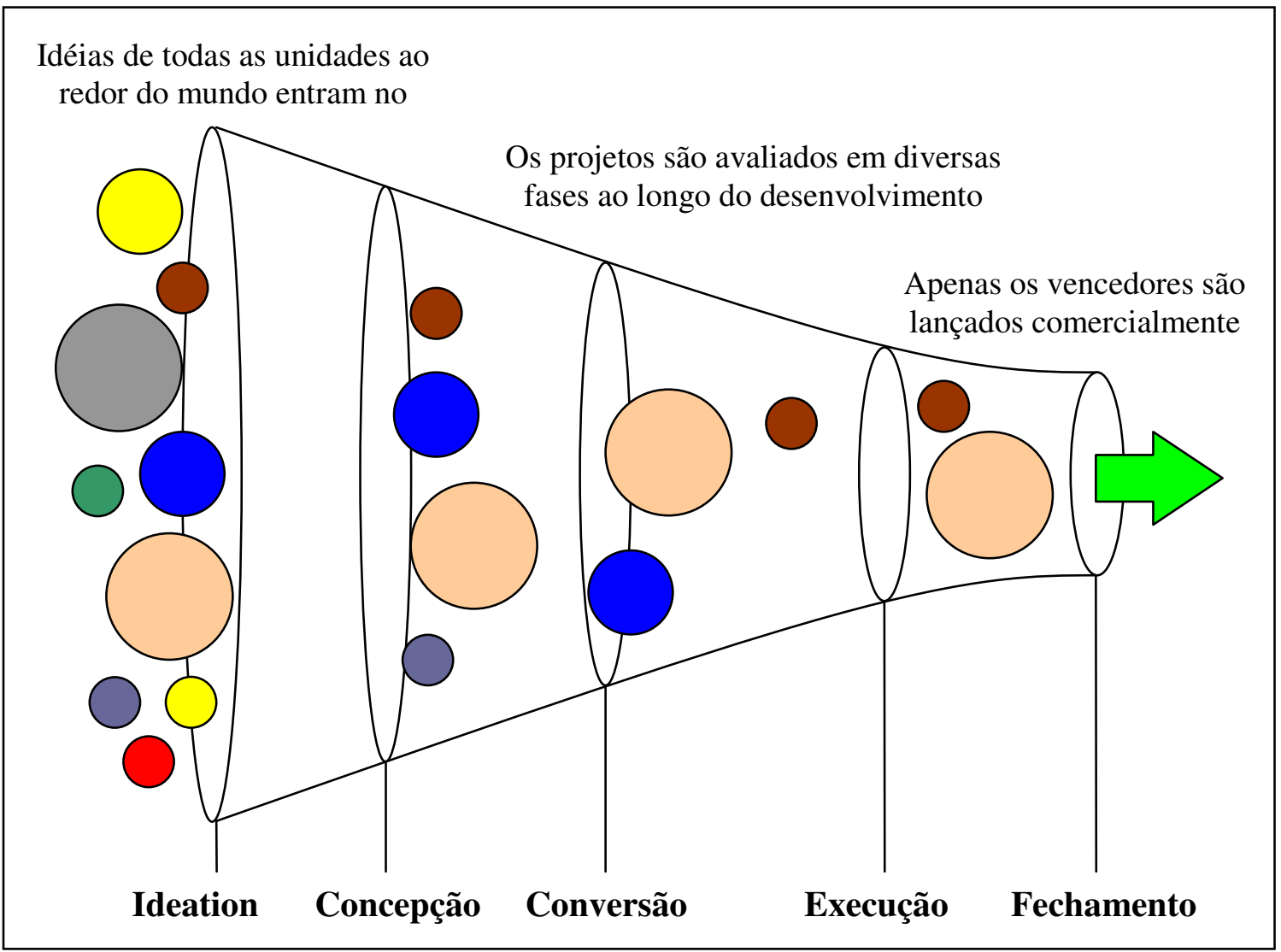

Figura 18 - Fases do processo de gestão do portfólio de novos produtos na ALFA

\subsubsection{BETA}

Olhando cuidadosamente o funcionamento da Divisão de Desenvolvimento da BETA é possível observar que há duas formas de se iniciar o projeto de um novo produto: uma delas é a forma já apresentada, planejada por meio do PGD. A outra é por meio de uma venda, ou o que a empresa chama de Ordem de Serviço (OS) especial. Quando uma venda estratégica depende de uma solução especial que envolve a criação de um novo produto ou a modificação de um produto já existente, normalmente a área comercial da empresa (Vendas, Engenharia de Aplicações Nacional ou Internacional etc) convoca uma reunião na Divisão de Desenvolvimento para apresentar a oportunidade de venda. Um grupo de especialistas analisa o problema, localiza no portfólio de produtos a solução mais conveniente e analisa se é possível atender os requisitos do negócio, sempre observando escopo, prazo e custos. Inúmeras vezes, a empresa opta por efetuar a venda e acionar a Divisão de Desenvolvimento 
para iniciar um ou mais projetos especiais. São projetos curtos, normalmente de semanas ou poucos meses, com alta prioridade, para atender essas vendas urgentes. Mesmo com esse processo de análise para o início de novos projetos, parece faltar na BETA a predisposição para ignorar projetos menores, que a princípio soam como uma boa oportunidade, mas que no longo prazo fazem com que a empresa perca o foco e que acabe por iniciar muitos projetos de pouca importância, atrasando projetos de maior impacto. Esse problema, citado por Cooper et al. (1997), pode ser minimizado por meio de uma gestão mais eficiente do portfólio de projetos.

Os projetos propostos no PGD são classificados como novos produtos ou manutenção, tecnologias novas ou dominadas e podem ainda ser projetos de hardware ou de software. Além disso, os projetos são classificados em função das linhas de produtos, o que ajuda principalmente na análise dos recursos humanos necessárias, já que a Divisão de Desenvolvimento é organizada em grupos de especialidades e todos os grupos podem trabalhar em qualquer tipo de projeto. Porém, não se constatou o uso dessa classificação como forma de comparação entre projetos ou critério de análise e seleção. O tipo do projeto é usado nos indicadores de retorno de investimento para o cálculo do retorno esperado do produto. A análise de risco e o levantamento de probabilidades de sucesso técnico ou sucesso comercial são elaboradas qualitativamente, mas nem sempre são documentadas para posterior análise ou comparações. Há ainda uma separação entre projetos eletrônicos e projetos mecânicos. Até 2006 havia duas equipes separadas e em 2007 a Divisão de Desenvolvimento Mecânico e a Divisão de Desenvolvimento Eletrônico foram unificadas criando a Divisão de Desenvolvimento, sob o comando do Diretor de Desenvolvimento. Na prática, cada equipe ainda ocupa prédios separados e trabalha em suas especialidades, porém, as reuniões para acompanhamento dos projetos são realizadas com a participação de representantes de todas as equipes. Segundo o Diretor de Desenvolvimento, há a intenção de reunir as duas equipes em um mesmo local ainda em 2008.

Merece nota o fato de que normalmente a análise técnica do conceito é suficiente para a aprovação do projeto, isto é, para promovê-lo de projeto listado no PGD a projeto ativo, em desenvolvimento, desde que não haja investimentos muitos altos ou que não envolva tecnologias inéditas para a empresa. Não há a necessidade de elaborar um plano de negócios detalhado para cada projeto. A empresa nesse sentido trabalha muito com a experimentação, desenvolvendo vários protótipos mesmo após o projeto ter sido aprovado pela diretoria. Diferentemente de outras empresas abrangidas nessa pesquisa, a BETA via de regra não divide a aprovação em fases, como conceito, detalhamento, protótipo etc. Essas atividades na 
maioria dos casos são realizadas após a aprovação do projeto, o que significa que após o projeto ter sido aprovado, dificilmente ele será cancelado, mesmo após falhas em protótipos ou a verificação de que os investimentos ou o tempo previstos não serão suficientes. Se o produto ainda for de interesse da empresa, o projeto sofre modificações, mas não é cancelado. Essa postura apresenta uma série de problemas e leva a empresa a uma menor eficiência se comparada a outras empresas que utilizam um processo de gestão mais estruturado, como no caso da ALFA e da TIGRE.

O fato de a empresa realizar uma análise mais superficial, sem a elaboração de um plano de negócios formal para o projeto, a torna mais flexível para iniciar novos projetos e pode até mesmo parecer uma vantagem à primeira vista, porém, tem um custo elevado no longo prazo. Com um número excessivo de projetos para sua capacidade de desenvolvimento (recursos financeiros e pessoas) a BETA freqüentemente tem mais projetos em andamento do que o ideal. Essa falta de foco leva ao atraso sistemático nos prazos de entrega de novos projetos e à degradação da qualidade nos produtos finais. De acordo com Rabechini Júnior, Maximiano e Martins (2005), espera-se que os gerentes tenham dados mínimos antes de iniciar seus projetos, tais como objetivos, informações sobre prazo e custo, premissas a serem realizadas, indicadores de acompanhamento, restrições e riscos. O levantamento dessas informações é fundamental para decidir o investimento em um projeto e nem sempre esse levantamento ocorre na empresa. Outro problema é a sobrecarga dos desenvolvedores, que freqüentemente trabalham em mais de 3 projetos ao mesmo tempo, reduzindo muito sua produtividade de acordo com o que apontam Clark e Wheelwright (1992).

Após a decisão de iniciar um projeto, um coordenador é escolhido pelo diretor, em conjuntos com os gerentes dos grupos, de acordo com as competências e habilidades específicas necessárias. Após sua nomeação ele elabora o Documento de Requisitos de Entrada (DRE) do projeto. Os coordenadores de projeto são responsáveis pelo levantamento de informações técnicas e, eventualmente, financeiras, que são analisadas em uma rodada de reuniões com a participação de diversas áreas, tais como: engenharia, vendas, marketing, fábrica, qualidade e assistência técnica. A aprovação do DRE nessa reunião marca o início formal do projeto. Além do DRE, também é possível autorizar o inicio de um projeto por meio de um documento chamado Estudo Técnico, que não exige um processo tão formal de aprovação quando o do DRE e que também não exige a participação de outras áreas da empresa, ficando restrito à aprovação interna na Divisão de Desenvolvimento. Esse mecanismo é usado para projetos simples ou adaptações em produtos, ou ainda para projetos muito urgentes. No caso de projetos com escopo mais complexo, investimentos e prazos 
maiores, normalmente o DRE é sempre realizado, dada a sua abrangência, mas no caso projetos incrementais ou para atender OS especiais, a empresa recorre apenas ao Estudo Técnico para agilizar o processo de aprovação, uma vez que ele depende apenas da aprovação interna na Divisão de Desenvolvimento.

Durante o processo de elaboração do DRE, não são usadas ferramentas financeiras tais como VPL, TIR ou ROIC. Além disso, não foram encontradas evidências do uso sistemático de técnicas quantitativas (financeiras) nas reuniões de análise do DRE. O levantamento financeiro mais comumente empregado é o custo estimado do projeto, baseado em um orçamento simplificado que inclui o esforço para execução do projeto em horas, os materiais e aquisições necessárias para protótipos e industrialização, além do custo estimado para o produto. Via de regra não há uma análise detalhada sobre potencial de mercado ou viabilidade comercial. A análise e escolha dos projetos é qualitativa, baseada na experiência dos executivos envolvidos no processo e nas informações de mercado disponíveis. O DRE padrão não possui informações detalhadas sobre os investimentos necessários para o projeto, sendo mais restrito aos aspectos técnicos e prazos estimados para sua execução. Porém, nota-se que uma análise de custos é elaborada em função do nível de complexidade, sendo que projetos com tecnologias dominadas, ou que não exigem a compra de novas máquinas ou ampliações nas linhas de produção, normalmente não são analisados em profundidade. $\mathrm{O}$ processo vigente na empresa pressupõe que o projeto será absorvido pelos recursos disponíveis e sua execução dependerá das prioridades determinadas pela diretoria ou pela demanda de curto prazo de clientes.

Chama a atenção o fato de não haver praticamente nenhum envolvimento da área financeira da empresa na avaliação dos projetos, não havendo troca de informações com esta área. Na BETA sobressai a análise técnica e qualitativa da Divisão de Desenvolvimento e da diretoria. O investimento necessário para execução do projeto é apenas estimado em termos de custos com horas do pessoal de engenharia, custos com certificações em laboratórios externos e assim por diante. Nos casos onde houve uma análise mais detalhada, o próprio coordenador de projetos foi o responsável por coletar, organizar e apresentar as informações. Contudo, não há evidências de que essas informações sejam usadas ao longo do projeto, e principalmente ao final do projeto para análise de performance ou em melhorias no processo. Também não ficou evidente se há um acompanhamento preciso dos custos dos projetos. Nesse sentido, porém, desde 2005 alguns indicadores têm sido implantados para melhorar o acompanhamento, porém seu uso ainda se encontra em estágio de implantação. 
É possível analisar a ausência de indicadores financeiros na análise dos projetos por dois pontos de vista. O primeiro vai de encontro ao que afirma Cooper et al. (1999), que a maioria dos modelos matemáticos para análise e seleção dos projetos historicamente se provou inadequada para o tratamento do risco e da incerteza associados aos projetos de desenvolvimento de novos produtos. O uso desse tipo de informação por si só não leva em conta as relações entre múltiplos projetos, além de falhar nos aspectos do uso compartilhado de recursos. Os gerentes percebem que essas ferramentas financeiras são difíceis de entender e utilizar. O segundo ponto de vista é com relação à maturidade da empresa na gestão do portfólio de projetos. Tais indicadores financeiros dependem de informações como a demanda prevista, preço médio estimado, investimentos, custo do capital utilizado para financiar o projeto, além de uma série de outras informações que não são parte do processo de desenvolvimento de produtos da BETA. Ao comparar esse aspecto da gestão de projetos com as outras empresas desse estudo verifica-se que essa empresa está em um nível anterior de maturidade e poderia se beneficiar caso aperfeiçoasse seu processo de gestão combinando elementos quantitativos ao seu processo de gestão qualitativo. Assim, a empresa poderia obter melhores resultados como afirma Cooper et al. $(1997,1999)$.

A análise apenas com base no DRE nem sempre leva em conta a sinergia com outros projetos, dando a avaliação do projeto um caráter mais individual. Assim, a priorização ou a ordem de execução dos projetos é arbitrada pelo Conselho de Acionistas em conjunto com a Diretoria, onde o Diretor da Divisão de Desenvolvimento tem um papel primordial. Uma vez priorizados os projetos, é possível então alocar os recursos disponíveis entre eles. Porém, a ausência da análise conjunta vai contra os modelos teóricos de gestão de portfólio, que apontam como sendo de fundamental importância a avaliação explícita das dependências entre os projetos. Archer e Ghasemzadeh (1999) propõem uma fase de avaliação especificamente para a análise das sinergias, onde diversas opções de portfólio são simuladas com o objetivo de encontrar a melhor combinação possível, ou a combinação que criará o maior valor para a empresa. Apesar da empresa privilegiar a análise individual dos projetos, há uma evidente preocupação em equilibrar projetos de alto e baixo risco, curto e longo prazo, tecnologias novas e tecnologias dominadas. Há também uma preocupação com relação às tecnologias envolvidas no projeto, se já são dominadas ou se demandarão investimentos como contratação de terceiros, recrutamento de novos funcionários ou mesmo treinamentos específicos. Isso é demonstrado pela análise crítica nas reuniões de formulação e aprovação do DRE ou apresentação de Estudos Técnicos para OS Especiais. 
Uma vez que o projeto teve seu DRE aprovado, segue-se uma fase de planejamento detalhado, onde o coordenador elabora um documento chamado Documento de Planejamento do Projeto (DPL), que aprofunda a descrição do escopo, desdobrando os requisitos em tarefas mais detalhadas e listando os recursos humanos, materiais e financeiros necessários. Esse detalhamento é apresentado em uma reunião com a presença dos gerentes e do diretor da divisão, quando eventuais ajustes são realizados. Neste documento podem constar os seguintes itens:
a. Responsáveis de cada tarefa;
b. Datas de início e término previstas para cada tarefa;
c. Marcos e eventos principais;
d. Dependências e restrições de cada tarefa;
e. Testes e verificações;
f. Reuniões de análises críticas;
g. Reuniões de interface;
h. Módulos do projeto;
i. Atividades de montagem e prototipagem;
j. Atividades de certificação;
k. Atividades de validação;
1. Atividades de industrialização;
m. Atividades de marketing;
n. Atividades de treinamento.

O DPL indica as datas de início e de término previstas para cada atividade, que são posteriormente atualizadas o andamento do projeto, com acompanhamento da diretoria. A partir desse documento são estimadas as necessidades em termos de competências técnicas e força de trabalho. Como a empresa não conhece precisamente sua capacidade de desenvolvimento total e disponível em cada momento, seria interessante o uso de históricos de projetos anteriores para as estimativas. Porém, não é evidente o uso desses históricos ou de cronogramas de projetos anteriores para auxiliar nesse planejamento. Após a aprovação do DPL, o coordenador do projeto passa à fase de alocação dos recursos, isto é, a definição de quem vai trabalhar no seu projeto, e quando. Porém, a alocação dos recursos ainda depende da prioridade do projeto, que muitas vezes depende de determinações do Conselho de Acionistas e da diretoria, que define as prioridades em termos dos investimentos necessários, das tecnologias e competências disponíveis no momento e dos riscos inerentes ao negócio. Essa análise de riscos é elaborada de forma qualitativa. 
Assim que um projeto recebe prioridade e é autorizado para iniciar a fase de desenvolvimento, os recursos são alocados. Há um modelo muito flexível de alocação de recursos na Divisão de Desenvolvimento da BETA. O coordenador pode negociar diretamente com os desenvolvedores, gerentes, outros coordenadores e em caso de conflitos, recorrer ao diretor. Os impasses são normalmente resolvidos em uma reunião com todos os interessados, por meio de consenso. O principal recurso para resolução de conflitos e a prioridade do projeto. Dificilmente um coordenador mais influente consegue sobressair com esse sistema, o que parece ser uma vantagem sobre estruturas mais formais e hierarquizadas e previne os problemas de atraso em projetos apontados por Fricke e Shembar (2000). Os gerentes de grupo são responsáveis por atividades administrativas e pela gestão das prioridades das pessoas em seu grupo, além de também coordenarem projetos. A gestão das pessoas e dos recursos disponíveis é normalmente realizada pelos coordenadores de projeto em conjunto com os gerentes. O diretor tem o papel de traduzir os objetivos estratégicos da organização em planos e atividades priorizadas. Ele pode alocar e redirecionar pessoas e recursos para projetos com maior prioridade além de mediar a resolução de conflitos entre coordenadores de projetos e gerentes de grupo.

O planejamento e o acompanhamento dos projetos são realizados por meio de cronogramas, planilhas e outros documentos criados e controlados pelo coordenador do projeto, mas armazenados de forma fragmentada. Há uma sistemática clara e eficiente de backup, mas não há nenhum mecanismo para garantir que os cronogramas atualizados estejam disponíveis para acesso na rede corporativa. Não há um sistema único que concentre as informações de todos os projetos em andamento. Os documentos de projeto, cronogramas e outras informações ficam distribuídos. A BETA é a única empresa avaliada nessa pesquisa que não possui um sistema para centralizar as informações sobre todos os projetos e para acompanhar a evolução do desenvolvimento. Isso indica que a empresa precisa investir na sua estrutura de gestão dos projetos sob pena de perder sua competitividade.

Para atender os projetos oriundos de OS especiais os recursos são realocados entre os projetos em andamento. Essa repriorização, muitas vezes, exige a análise e a anuência do diretor, bem como do coordenador do projeto e dos gerentes envolvidos. Muitas vezes, essas mudanças trazem impactos negativos nos projetos já em andamento, principalmente atrasos nos cronogramas e um certo desconforto para os desenvolvedores, conforme foi comprovado pela recente pesquisa no departamento. Por outro lado, a flexibilidade obtida com esse modelo permite que a empresa tire proveito de boas oportunidades de negócio, se valendo de sua estrutura ágil e até certo ponto informal, como relata um dos desenvolvedores: "Temos que 
estar preparados para as oportunidades que aparecerem. Muitas vezes uma OS especial começa sem nenhum documento formal, apenas com os requisitos técnicos da aplicação e só na entrega do produto é que temos toda a documentação de projeto pronta também". O principal problema nessa dinâmica está relacionado à estrutura da divisão de desenvolvimento, onde não há uma equipe dedicada para desenvolver esse projetos urgentes, como no caso da WEG e da ALFA. Essas duas empresas reconheceram há bastante tempo o problema causado pela interferência de pequenos projetos nos projetos já em andamento e criaram equipes especificamente para minimizar esse problema.

Contudo, a estrutura observada na divisão de desenvolvimento da BETA também encontra um paralelo na literatura sobre estrutura organizacional, não sendo puramente orientada a projetos como a apresentada por Slack et al. (2002). A grande maioria dos desenvolvedores executa tarefas voltadas ao desenvolvimento de múltiplos projetos de novos produtos, mas também empregam boa parte de seu tempo em atividades de assistência técnica, reuniões para auxílio na definição de propostas comerciais, visitas para solucionar problemas em clientes, suporte para as fábricas, dentre outras atividades, que não estão diretamente ligadas à execução dos projetos dos novos produtos. Esse tipo de rotina de trabalho remonta à estrutura da empresa em hipertexto proposta por Nonaka e Takeushi (1995). A organização em hipertexto representa uma estrutura onde ocorre intensiva criação e transformação de conhecimento por meio de atividades na camada de projetos, onde inovações ganham espaço para emergirem como novos produtos ou processos. As atividades rotineiras, ou que não sejam fim, são acomodadas na camada de negócios. Nesse tipo de organização as pessoas estão freqüentemente alternando sua atuação entre as camadas. Porém, no caso da BETA, há um excessivo número de transições entre as camadas de negócio e de projetos, além de uma excessiva transferência de pessoas entre projetos. É possível que esse excesso de transições causando grande perda de energia dos desenvolvedores e coordenadores, causando perda de eficiência no processo de desenvolvimento de produtos. Clark e Wheelwright (1992) defendem que um número excessivo de projetos (> 2) sobrecarrega o desenvolvedor com atividades que não criam valor, reduzindo sua produtividade. Por outro lado, há um consenso na BETA de que essa flexibilidade representa uma vantagem competitiva. "Não existem muitas empresas no mundo capazes de modificar e entregar um produto de alta tecnologia como os que nós fabricamos aqui em apenas algumas semanas", afirma um dos coordenadores de projetos.

A partir do estudo realizado na BETA, um diagrama foi elaborado com os principais elementos representativos da gestão do portfólio de projetos de novos produtos nessa 
empresa. O diagrama da figura seguinte ilustra os aspectos estruturais, fluxo de informações e as principais fases envolvidas no processo e seus atores. O diagrama retrata o mecanismo de gestão de portfólio de projetos utilizado pela BETA. A gestão de portfólio de projetos de novos produtos segue um processo qualitativo apoiado no profundo conhecimento de seu corpo técnico para efetuar a análise, seleção e priorização dos projetos. $\mathrm{O}$ acompanhamento dos projetos é realizado por meio do Masterplan, um subconjunto do PGD, que contempla apenas os projetos ativos.

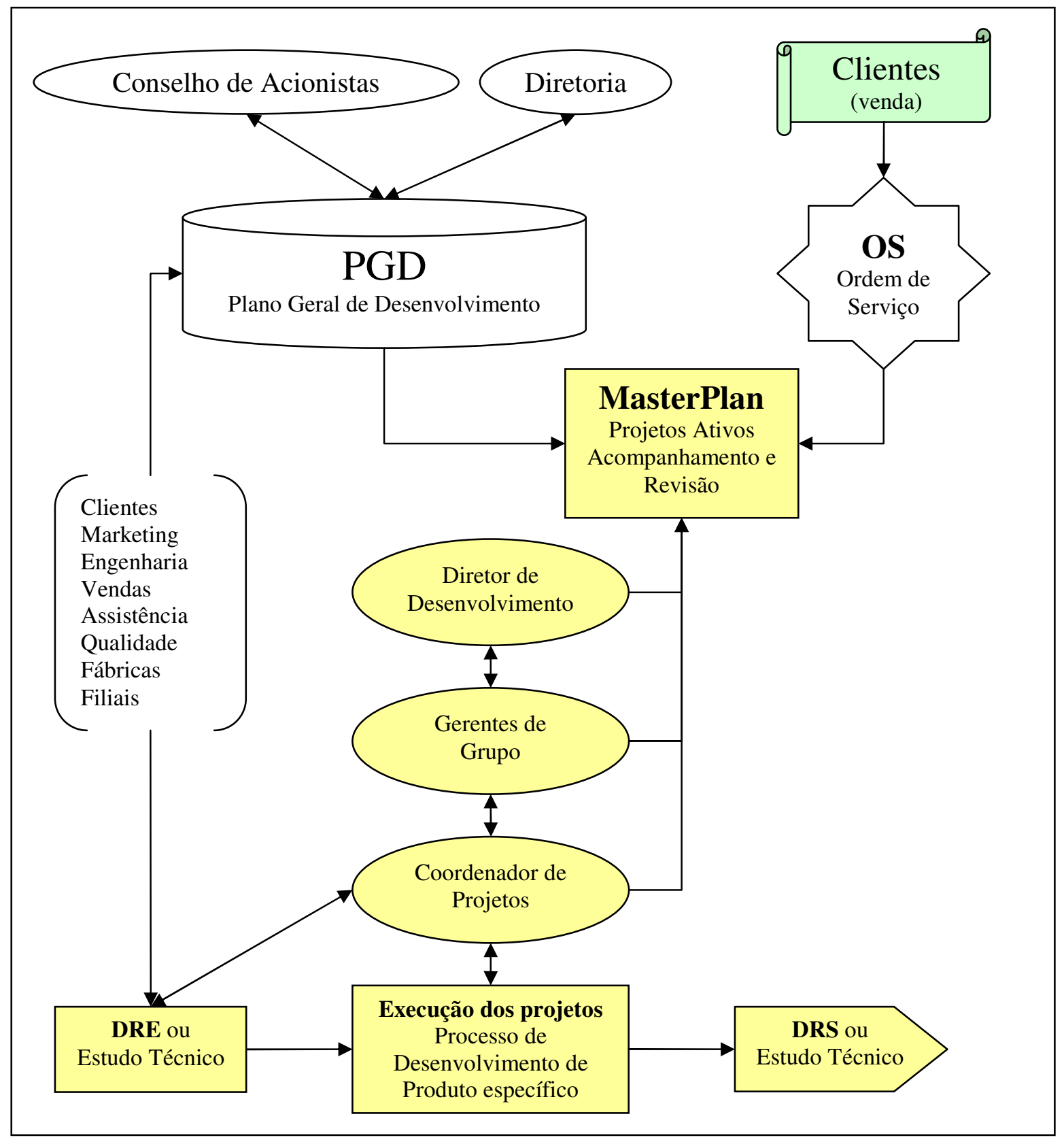

Figura 19 - Diagrama do processo de gestão do portfólio na BETA 


\subsubsection{TIGRE}

O processo de gestão de portfólio é conduzido pelo departamento de PD\&E, que é o responsável por coletar e organizar as informações dos vários projetos e submetê-los à aprovação da diretoria. A TIGRE ainda não possui um sistema de informação dedicado para a GPPNP. Atualmente, o pessoal do departamento de P\&D utiliza planilhas e alguns softwares isolados, organizados de forma manual.

$\mathrm{Na}$ análise das novas idéias, são observados cinco conceitos básicos: foco na obra preservando a racionalização; funcionalidade para servir a várias aplicações; simplificação pensando na instalação e manutenção; durabilidade e estética. Esses conceitos orientaram o desenvolvimento de linhas como a Aquatherm ${ }^{\circledR}$, para água quente e fria. Este sistema é mais prático e rápido de ser instalado que o similar em cobre. O produto também favorece a economia durante o uso: como o material tem baixa condutividade térmica, se gasta menos energia para manter a água quente (TIGRE, 2008).

A gestão do portfólio de projetos de novos produtos na TIGRE está intimamente ligada ao processo de desenvolvimento de produtos Utiliza-se um processo com fases e portões, similar ao stage-gate de Cooper (1994), consistindo de 5 fases (análise das idéias, projetos, desenvolvimento, fabricação e lançamento) e 4 portões (P1, P2, P3 e P4), como ilustra a figura seguinte:

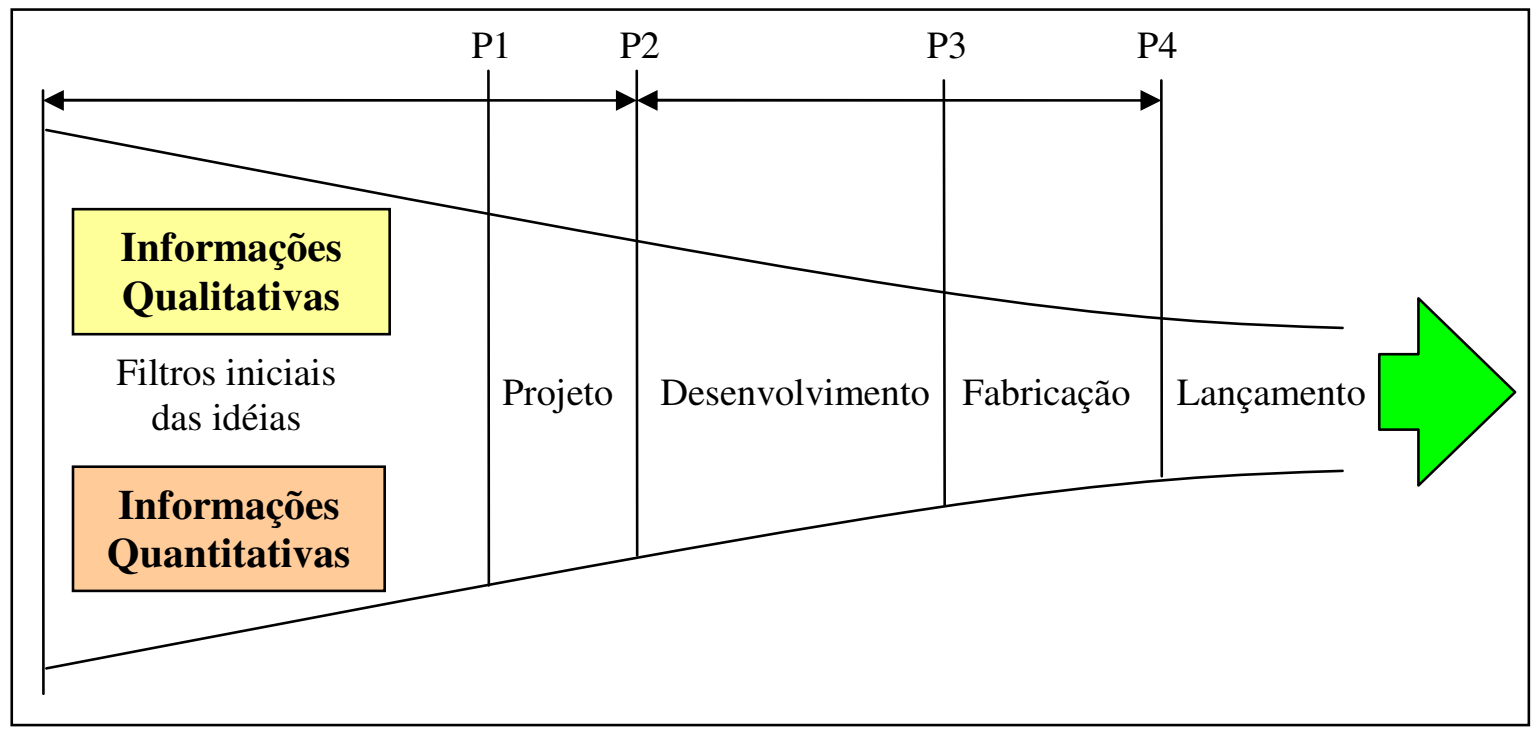

Figura 20 - Fases do processo de desenvolvimento de produtos da TIGRE 
A divisão de fases do processo é bastante similar àquela encontrada na ALFA. Os filtros iniciais também procuram classificar os projetos por grau de inovações: radical ou incremental. As plataformas de produtos dão origem a linhas com diversos modelos. A TIGRE possui o que eles chamam de portfólio de tecnologias e portfólio de produtos. O portfólio de tecnologias está relacionado aos materiais e processos de fabricação. O portfólio de produtos concentra os desenhos industriais, por exemplo.

A avaliação da proposta de projeto para o novo produto começa com uma exposição da idéia, na forma de um plano de negócios resumido, em uma reunião da diretoria. Para cada projeto são elaborados slides com informações qualitativas e quantitativas. Após a apresentação o projeto recebe um sinal verde ou vermelho para a próxima fase. Cada fase do projeto culmina com uma nova análise que caracteriza um dos portões de P1 a P4.

Na TIGRE consegue-se evitar a sobrecarga de informações de cada projeto nas reuniões de análise e seleção por meio dos filtros iniciais (P1). Esses filtros iniciais são aplicados por áreas como PD\&E, Marketing, Processos, Moldes, Logística, Controladoria, além do Comitê estratégico formado por representantes dessas diversas áreas. Esses filtros iniciais garantem que apenas propostas viáveis passem para a fase de projeto.

Para os projetos aprovados no portão P1, a equipe elabora um detalhamento do projeto, acrescentando informações técnico-comerciais, previsões orçamentárias mais detalhadas, cronograma de entregáveis, análise de risco etc. Essa fase compreende também a construção de protótipos (modelos do produto), para prevenir possíveis problemas nas fases posteriores. O departamento mantém um registro histórico detalhado de cada projeto desenvolvido. Esse histórico é usado intensivamente no planejamento de novos produtos e também em todo o processo de avaliação e seleção.

Se o projeto detalhado for aprovado no portão P2, ele passa então para a fase de desenvolvimento, que é finalizada com mais uma reunião de análise crítica que marca o portão P3, a partir do qual são feitos os investimentos para aquisição dos meios de produção. O lançamento do produto ocorre após P4, quando o produto segue para o lançamento no mercado, sendo monitorado após seu lançamento para verificar se os objetivos estratégicos esperados são atingidos.

Devido à peculiaridade dos produtos fabricados pela TIGRE, em sua grande maioria construídos às partir da injeção de plásticos, $\mathrm{o} \& \mathrm{D}$ investe pesadamente para desenvolver os conceitos e os protótipos (antes de P1 e entre P1 e P2), para adquirir informações mais detalhadas e ricas para análise nas fases iniciais. Os moldes para injeção construídos nas fases 
de desenvolvimento e fabricação são extremamente caros, sendo a razão pela qual praticamente não se cancelam projetos após essa fase.

O processo de desenvolvimento de produtos foi completamente remapeado a partir de 2002. Com isso, conseguiu-se reduzir o tempo entre a idéia e o lançamento em 50\%, além de sistematizar uma série de atividades do processo de GPPNP, como a introdução da análise de diversos indicadores financeiros. Além das informações financeiras, é utilizado um Score Card (SC) próprio para pontuar os projetos. Os projetos são divididos por complexidade e grau de inovação (radical ou incremental), e diversas informações são coletadas e estimadas. $\mathrm{Na}$ análise e seleção dos projetos é bastante comum o uso de gráficos de ROI x Investimento, ROI x Risco, Faturamento x Investimento. Além disso, também são usados os seguintes critérios para avaliar os projetos: retorno potencial, preço potencial de venda, expectativa de demanda, custo máximo. Veja um exemplo ${ }^{1}$ na figura seguinte:

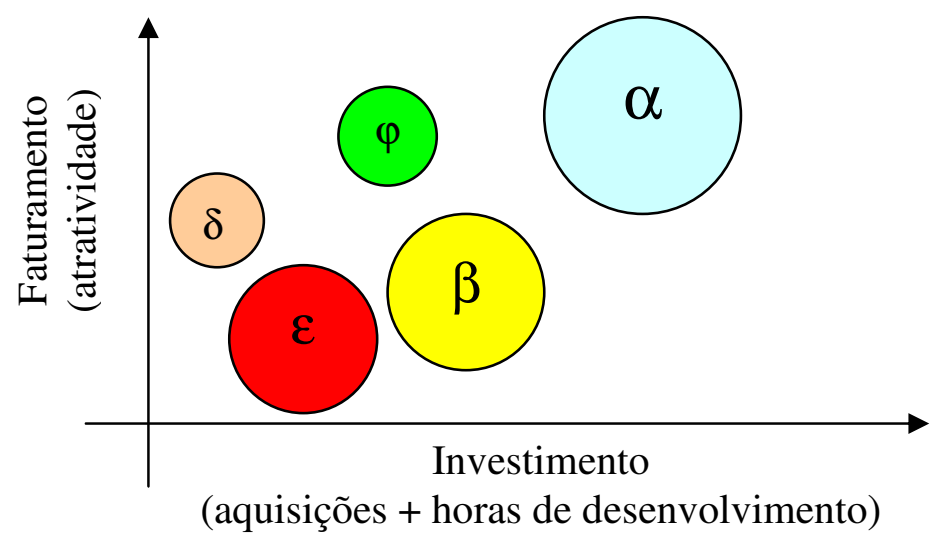

Figura 21 - Exemplo de gráfico de bolhas da Atratividade x Investimento usado na TIGRE

Os projetos com maior atratividade e menor investimento são os preferidos, em geral. Contudo, também há a análise de alinhamento estratégico da diretoria, na qual o projeto ganha um peso na seleção e na priorização mesmo que suas figuras de atratividade e investimento estejam desfavoráveis. Nesse aspecto, esse peso de ordem qualitativa representa um ajuste sobre os indicadores financeiros usados na avaliação e corresponde aos ajustes no portfólio previstos por Archer e Ghasemzadeh (1999). Segundo os entrevistados, essa análise gráfica facilita na identificação de projetos com alto potencial. Alguma sinergia entre os projetos também é observada em termos de agrupamento de produtos semelhantes, famílias e linhas. A sinergia é verificada também em análises após o lançamento do produto, por meio da

\footnotetext{
${ }^{1}$ Os nomes dos projetos e informações numéricas foram omitidos do gráfico devido à confidencialidade dessas informações.
} 
correlação entre as vendas de diferentes produtos. Porém, a gestão do portfólio de projetos de novos produtos na TIGRE privilegia uma análise mais individual de cada projeto.

A partir do lançamento do produto, se inicia uma monitoração mensal de performance na produção, qualidade e vendas. Essa monitoração tem, entre outros objetivos, a intenção de verificar se o planejamento para o produto está sendo atingido, se as expectativas e números previstos no planejamento inicial foram bem dimensionados. Essa característica coloca a TIGRE entre as empresas que buscam o aperfeiçoamento contínuo de seu processo de GPPNP.

Todos os produtos competem pelo mesmo orçamento, não há uma divisão por área de atuação ou por grupo de projetos. Isso indica, entre outras coisas, que a TIGRE não tem como objetivo explícito um equilíbrio entre projetos para as suas três principais áreas de negócio. Da mesma forma, a prioridade de cada projeto é em função daquele que oferecer o maior retorno. Porém, como afirma um dos entrevistados, há também um peso estratégico que é considerado na priorização, a partir de um modelo de decisão elaborado internamente e apoiado pela alta direção da empresa.

A alocação de recursos para os projetos é um processo planejado pela gerência e aprovado pela diretoria. Para cada projeto é designado um líder, que será o responsável pela gestão técnica e pela equipe do projeto. Cada líder tem uma especialidade (água, elétrica, design etc) e escolhe os recursos (pessoas) que deseja para determinado projeto e negocia sua alocação com os demais líderes e com o gerente de PD\&E, a partir do planejamento inicial aprovado pela diretoria. Os profissionais trabalham, em geral, em apenas um projeto de cada vez, ainda que para atividades mais específicas haja compartilhamento de recursos. Os conflitos resultantes desse compartilhamento e da competição por recursos mais especializados ou eficientes são negociados na maioria das vezes entre os próprios líderes dos projetos. No lançamento do produto, o líder do projeto promove um evento interno, para reconhecer o esforço de cada participante daquele projeto. O líder também realiza uma "auditoria" ao final do projeto para compilar as lições aprendidas, erros e acerto do projeto. Eles fazem questão de difundir ao máximo essas informações.

A figura seguinte representa o esquema resumido do processo de gestão de portfólio de novos projetos na TIGRE, com uma visão sobre a participação das áreas em cada fase do projeto: 


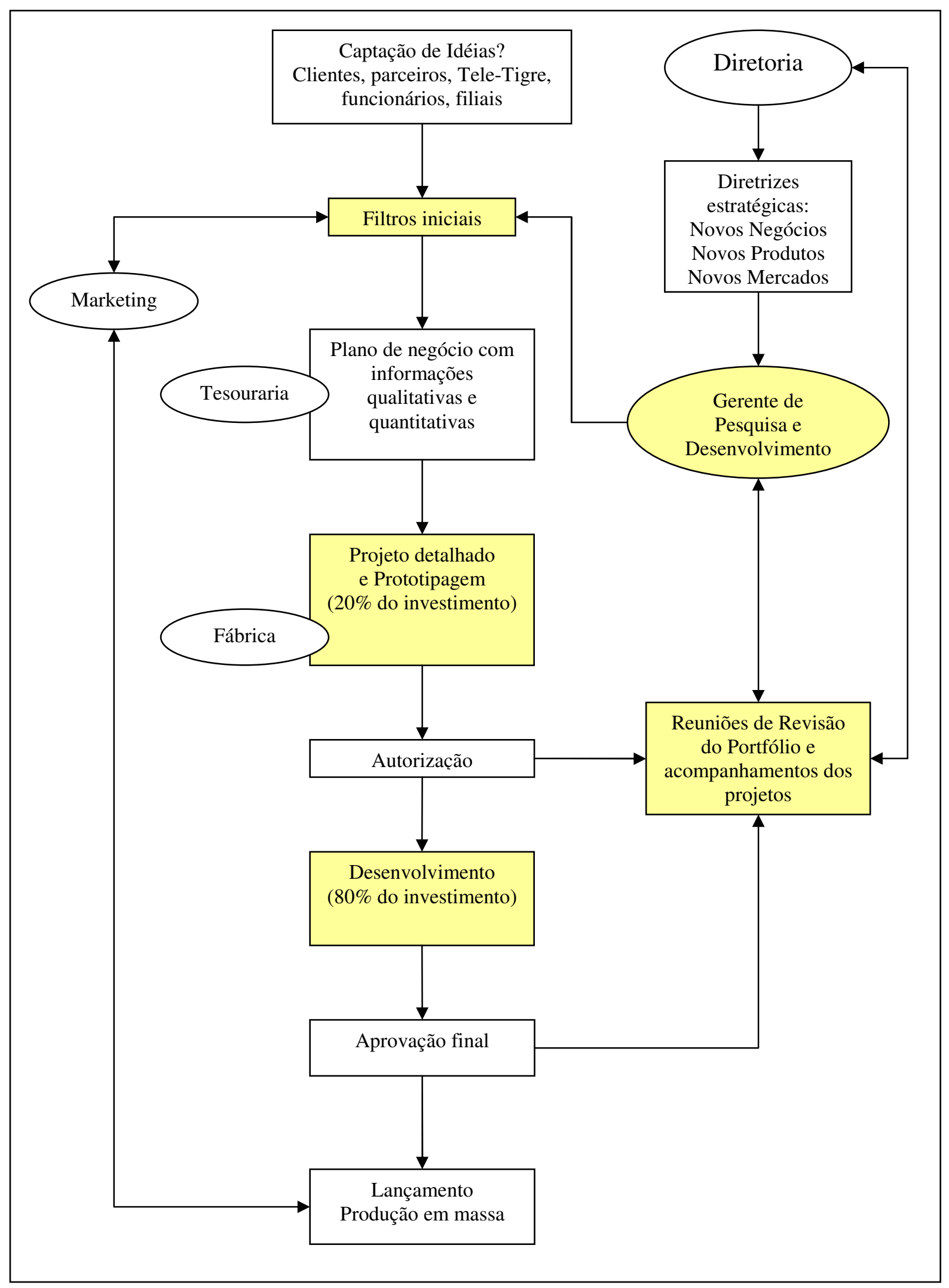

Figura 22 - Diagrama do processo de gestão do portfólio na TIGRE 


\subsubsection{WEG}

Antes de cancelar ou rejeitar alguma idéia no processo de pré-seleção dos novos projetos, sempre que possível, ocorre uma negociação onde os gerentes conversam com as áreas e analisam o mérito da idéia antes de aplicarem esse primeiro filtro. Essa é uma característica presente na cultura da WEG, da tomada de decisão coletiva. O gerente da engenharia de produtos, do P\&D e os gerentes de portfólio IEC e NEMA são os responsáveis pelas decisões nos primeiros níveis de filtro das idéias. Um dos fatores mais importantes nessa fase é o alinhamento estratégico, como comenta um dos gerentes entrevistados:

Várias orientações são definidas no planejamento estratégico, que tem informações claras do que a empresa quer e onde ela quer chegar. Mas, muitas vezes, essa estratégia não é totalmente clara do ponto de vista de engenharia. $\mathrm{O}$ desdobramento da estratégia em projetos cabe às áreas.

Cada área, analisando o planejamento estratégico da empresa, começa a investigar as propostas do banco de idéias, elaborando uma análise em conjunto com as chefias e a diretoria, mantendo os projetos que são alinhados estrategicamente e classificando-os de acordo com sua importância. Elabora-se então uma lista de prioridades para o ano, avaliando a capacidade de desenvolvimento atual da empresa e criando uma primeira lista de projetos, que é validada com as áreas de marketing, vendas e com a diretoria, em uma primeira rodada de validação. Após a validação, essa lista (PWQP) segue para análise na Comissão de Portfólio, como conta um dos gerentes entrevistados:

A Comissão de Portfólio é formada por um grupo de especialistas e de representantes das áreas de vendas, processos, $\mathrm{P} \& \mathrm{D}$, engenharia e outras áreas, que tenta classificar, selecionar e priorizar os projetos de acordo com critérios subjetivos e numéricos, tais como retorno e risco. Então, a comissão analisa se estrategicamente o projeto é importante naquele momento ou se ele está simplesmente desperdiçando recursos. Nós tentamos alinhar aquilo que é fácil de desenvolver e de baixo risco, com as necessidades e a estratégia da empresa.

A classificação e a priorização dos projetos ocorrem logo nas primeiras fases de análise. Os gerentes da Engenharia de Produtos e do P\&D separam os projetos de novas tecnologias, com maior risco, que vão para o P\&D para o desenvolvimento dos conceitos e protótipos. Os projetos com tecnologias já dominadas e que apresentam riscos menores são desenvolvidos pela engenharia de produtos. Sempre que possível os projetos são agrupados por linhas de produto, principalmente porque os recursos para desenvolvimento normalmente são compartilhados. Esse agrupamento por tipo de produto, por tipo de linha, por atividades a 
serem desenvolvidas, tenta também não só olhar o projeto em si, mas também elaborar uma análise e verificar o impacto nos outros projetos. O P\&D, por sua vez, classifica os projetos como novas tecnologias, otimização ou materiais. Cada projeto recebe um código: OTM (otimização), MT (materiais) ou NT (novas tecnologias).

Após a primeira rodada de avaliação, seleção e priorização na Comissão de Portfólio, os projetos aprovados são mais detalhados e discutidos novamente entre as áreas relacionadas. É realizada então uma segunda rodada na comissão, onde cada projeto listado na planilha do PWQP é validado novamente. Nessa segunda rodada, cada gerente tem que buscar informações do mercado, sobre os investimentos necessários, sobre o processo de fabricação. É elaborado um anteprojeto, um esboço, com o máximo de informações e detalhamento possíveis. Esse esboço é reapresentado e aprovado ou rejeitado pela comissão. Para realizar a análise comparativa dos projetos, podem ser usados indicadores financeiros. Porém, devido à dificuldade de prever o retorno do produto e de considerar o alinhamento estratégico, muitas vezes a avaliação é baseada também na experiência dos gestores, como conta um dos gerentes entrevistados:

Já estudamos algumas metodologias, tais como risco x benefício e payback, mas esbarramos muito no que era estratégico, naquilo que a diretoria patrocinava mesmo apresentando um risco elevado. Por exemplo, só entendendo o planejamento estratégico para ver que a China é uma prioridade, porque os produtos lá podem não ter a rentabilidade inicial desejada, mas podemos ganhar mercado depois.

É importante notar que a participação da empresa em mercados externos, tais como a China que foi citada no exemplo anterior, influencia a seleção dos projetos e a formação do portfólio. Outro fator levado em consideração na seleção dos projetos é o equilíbrio entre diferentes tipos de projeto, com alto e baixo risco, curto e longo prazo, o que se chama na literatura de balanceamento ou equilíbrio do portfólio (COOPER et al., 1997; ARCHER; GHASEMZADEH, 1999; RABECHINI JÚNIOR; CARVALHO, 2005, 2006). Tanto a Engenharia de Produtos quanto o departamento de P\&D busca esse equilíbrio. Como exemplo, no caso de $\mathrm{P} \& \mathrm{D}$, há sempre como objetivo um determinado número de horas em novas tecnologias, pesquisa em materiais ou otimização. Essas três atividades somam algo em torno de $60 \%$ dos recursos disponíveis. Há então mais $10 \%$ de assessoria, $20 \%$ para necessidades gerais (administrativas) do departamento e 10\% em outras atividades, entre elas até atividades não produtivas.

Após a segunda rodada de avaliação na comissão de portfólio, os projetos préselecionados e incluídos no PWQP (lista de projetos) passam para a diretoria. Até essa etapa, essa lista já selecionada, balanceada e priorizada contém projetos alinhados com o 
planejamento estratégico da empresa. Porém, alguns projetos ainda podem ser rejeitados pela diretoria, ou terem sua prioridade alterada. A seqüência de aprovação do projeto está ilustrada na figura seguinte:

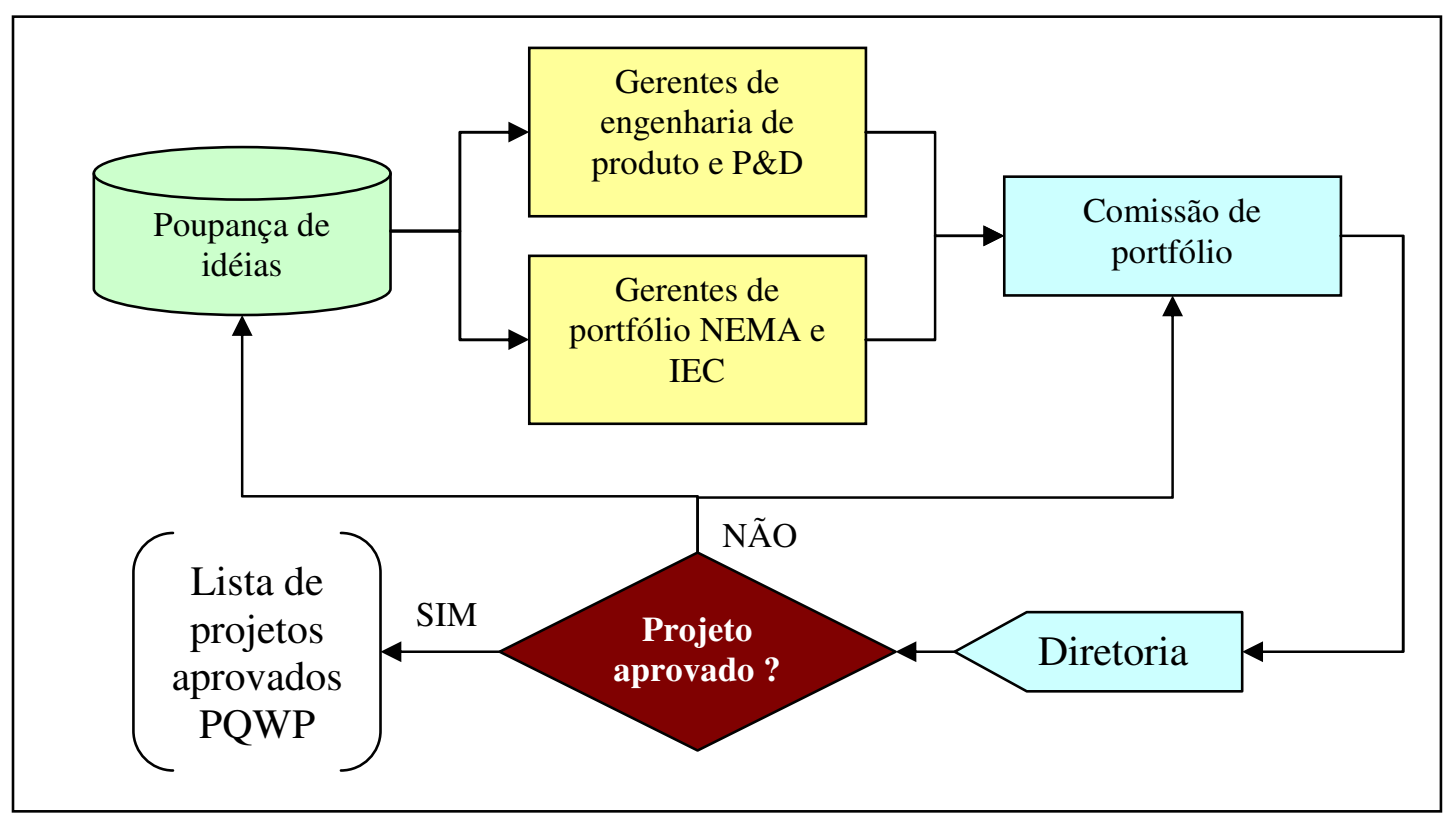

Figura 23 - Esquema ilustrativo das etapas para aprovação de um novo projeto na WEG

Assim que a diretoria aprova o conjunto de projetos, ajusta suas prioridades e autoriza o início do desenvolvimento, cada área passa para uma fase de detalhamento, com a elaboração do cronograma do projeto, o desmembramento do projeto em entregáveis com as descrições detalhadas e a alocação de recursos. Eventualmente, durante as negociações para alocação de recursos e até mesmo durante o desenvolvimento, as prioridades dos projetos podem ainda ser alteradas. Dependendo do tipo de projeto, esse planejamento detalhado fica a cargo da Engenharia de Produto ou do P\&D, onde os recursos para cada tarefa são dimensionados e alocados com as outras áreas da empresa. Durante essa etapa, a capacidade de desenvolvimento volta à discussão, e todas as opções conhecidas são avaliadas para atender as necessidades dos projetos, enquanto ao mesmo tempo tenta-se equilibrar o uso dos recursos. Dessa forma, a empresa procura compatibilizar os projetos aprovados com os recursos disponíveis, evitando que haja uma quantidade excessiva de projetos que poderia degradar a qualidade e comprometer os prazos. Nesse aspecto a WEG se encontra numa posição bastante moderna em acordo com os principais modelos teóricos e recomendações de Cooper e Edgett (2003), Hendriks et al. (1999) e Elonen e Artto (2003). 
O detalhamento do projeto evidencia a necessidade de recursos e competências internas e externas à empresa. A figura seguinte ilustra as opções em termos de recursos que são consideras pela WEG para o desenvolvimento de novos produtos:

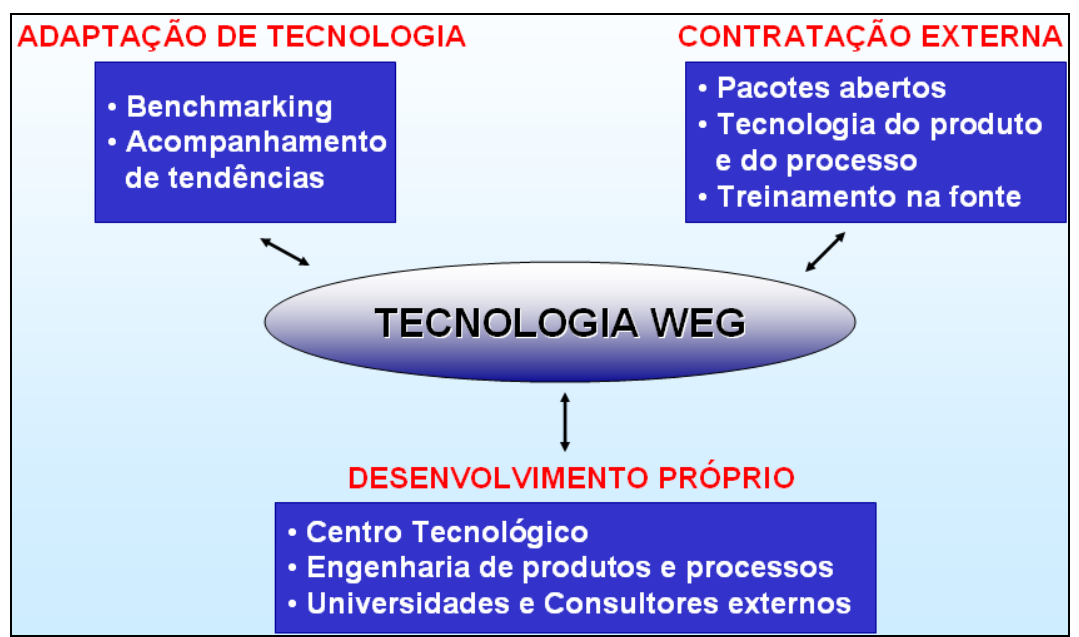

Figura 24 - Recursos utilizados no desenvolvimento de novos produtos e tecnologias ${ }^{1}$

O fato da administração da empresa historicamente funcionar muito bem por comissões, como os Círculos de Controle da Qualidade (CCQ's), leva a alocação e administração dos recursos a uma negociação interdepartamental. Então, as pessoas necessárias são alocadas pelo tempo negociado, como relata o gerente da engenharia:

Tudo que tínhamos planejado em novembro de 2006 já tinha sido ultrapassado em janeiro de 2007, devido a decisões tomadas com relação à China e Índia. Estamos realocando recursos entre alguns projetos e avaliando os impactos em outros que provavelmente teremos que postergar. Na semana que vem vamos discutir os projetos de Portugal para em seguida negociar todos esses projetos com $\mathrm{P} \& \mathrm{D}$, alocando os recursos de $\mathrm{P} \& \mathrm{D}$ e de outras áreas também.

Os recursos vão primeiro para o projeto de maior prioridade e assim sucessivamente. Para cada desenvolvedor ou especialista, os tempos são alocados em função da disponibilidade planejada para o ano seguinte e aprovada novamente na comissão de portfólio e na diretoria. É possível que ainda haja alguma alteração pedida pela diretoria, sendo necessária uma nova rodada de planejamento e negociação. Durante a negociação para alocação dos recursos é muito comum que hajam conflitos devido ao compartilhamento entre diversos projetos em andamento e novos. Cada equipe, ou cada especialista, atua simultaneamente em diversos projetos, alocando um determinado percentual do seu tempo. A proporção do tempo alocado e a definição do prazo para o trabalho dependem das prioridades

\footnotetext{
${ }^{1}$ Informação da palestra "Como Realizar a Gestão da Inovação nas Empresas” apresentada na UNINDUS em Curitiba, PR, por Sebastião Lauro Nau, gerente de P\&D da WEG Motores, em 27 de Novembro de 2007.
} 
que foram definidas já na comissão de portfólio. Esse processo de priorização e alocação de recursos é um processo de negociação que depende de várias reuniões entre vendas, engenharia, $P \& D$, processos, ferramentaria, diretoria, entre outras áreas, porque cada área tem os seus projetos, suas metas e seus objetivos. Por exemplo, a nova fundição a ser inaugurada em 2009 pode não estar alinhada como os mesmos objetivos de vendas, mas ao provocar a mudança de prioridades em alguns projetos ela afeta diretamente todas as áreas. Os conflitos que surgem desse processo dinâmico são resolvidos por consenso.

Sempre que necessário, os próprios gerentes da engenharia ou do $\mathrm{P} \& \mathrm{D}$ podem alterar a prioridade de um projeto, a menos que ela tenha sido determinada pela diretoria. Se o remanejamento de algum projeto não interferir na sua data de entrega, por exemplo, então o próprio gerente tem autonomia para esses ajustes. Mesmo em casos onde há necessidade de alteração de datas, é possível repriorizar, como explica o gerente de P\&D:

Mesmo alterando a data de entrega, há vezes em que eu negocio com meu cliente para reprogramar, antecipar ou adiar o cronograma. Outros trabalhos mais importantes podem tomar o lugar de um existente com a solicitação do meu diretor.

É possível que o processo de gestão do portfólio de projetos para novos produtos seja um dos passos na direção da excelência na gestão da inovação tecnológica como um todo. Observando o modelo misto do processo de inovação tecnológica, proposto por Rothwell e Zegveld (1985 ${ }^{1}$ apud NUCHERA et al., 2002), é possível fazer uma analogia entre as diversas comissões internas da WEG, de onde surgem idéias e por onde passam as propostas de projetos até se tornarem produtos, com os processos indicados no modelo: Veja a figura seguinte:

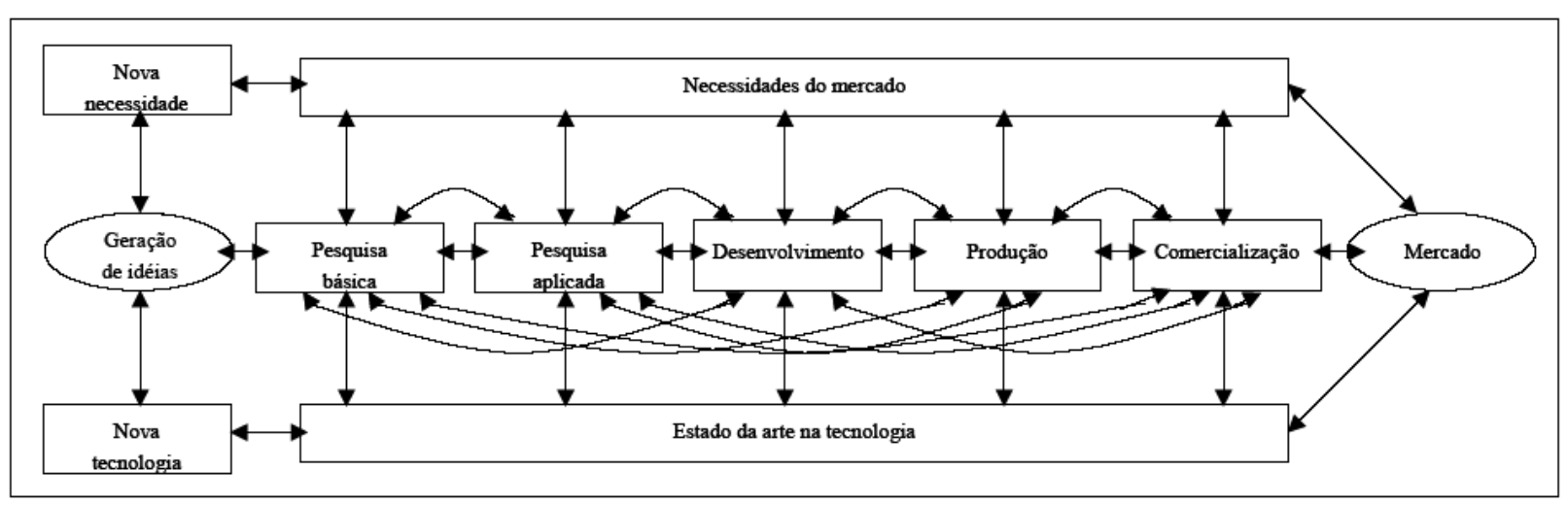

Figura 25 - Modelo misto do processo de inovação tecnológica

Fonte: adaptado de Rothwell e Zegveld (1985 apud NUCHERA et al., 2002).

\footnotetext{
${ }^{1}$ ROTHWELL, R.; ZEGVELD, W. Reindustrialization and Technology. London: Cartermill International, 1985. $288 \mathrm{p}$.
} 
A comunicação constante entre as áreas (ambiente interno) e com o ambiente externo reflete as conexões presentes no modelo de gestão. $\mathrm{O}$ fluxo de informações recorrente representado pela geração de idéias até o lançamento de um novo produto no mercado também é análogo ao que acontece na WEG. Esse modelo sugere que a inovação tecnológica é induzida a partir de um contato constante entre as áreas envolvidas no processo de inovação, produzindo um efeito de volta à pesquisa básica ou aplicada, caso os conhecimentos próprios não sejam suficientes. Essa estrutura organizacional também é encontrada na ALFA.

\subsubsection{Resumo comparativo da formação do portfólio}

Uma das etapas mais importantes no processo de gestão do portfólio é a sua formação, ou seja, a escolha dos projetos e a escolha da sequiência na qual serão desenvolvidos. Os modelos teóricos normalmente dividem essa etapa em diversos processos. Porém o modelo de Rabechini Júnior, Maximiano e Martins (2005) agrega as atividades de classificação, avaliação, seleção e priorização em um único processo, de acordo com o resumo mostrado no quadro seguinte:

\begin{tabular}{|c|c|c|c|c|}
\hline EMPRESA & CLASSIFICAÇÃO & AVALIAÇÃO & SELEÇÃO & PRIORIZAÇÃO \\
\hline ALFA & $\begin{array}{l}\text { Projetos de } \\
\text { desenvolvimento } \\
\text { tecnológico e } \\
\text { projetos de } \\
\text { desenvolvimento de } \\
\text { produtos grandes, } \\
\text { médios ou pequenos }\end{array}$ & $\begin{array}{l}\text { Plano de negócio } \\
\text { para cada projeto, } \\
\text { com indicadores } \\
\text { financeiros. Análise } \\
\text { sinérgica para evitar } \\
\text { sobreposições }\end{array}$ & $\begin{array}{l}\text { Análise qualitativa e } \\
\text { quantitativa no COMEX } \\
\text { Prioriza análise conjunta } \\
\text { dos projetos. } \\
\text { Procura cobrir todos os } \\
\text { objetivos estratégicos. } \\
\text { Forte influência das } \\
\text { filiais do exterior }\end{array}$ & $\begin{array}{l}\text { Alinhamento } \\
\text { estratégico e } \\
\text { retorno }\end{array}$ \\
\hline BETA & $\begin{array}{l}\text { Projeto com } \\
\text { tecnologia dominada } \\
\text { ou nova, hardware, } \\
\text { software, } \\
\text { manutenção ou novo } \\
\text { produto }\end{array}$ & $\begin{array}{l}\text { DRE com avaliação } \\
\text { técnica e análise } \\
\text { qualitativa. Sem } \\
\text { análise de sinergias }\end{array}$ & $\begin{array}{l}\text { Análise individual } \\
\text { predomina. Pouca } \\
\text { participação das unidades } \\
\text { do exterior }\end{array}$ & $\begin{array}{l}\text { Alinhamento } \\
\text { estratégico, } \\
\text { solicitação de } \\
\text { clientes }\end{array}$ \\
\hline TIGRE & $\begin{array}{l}\text { Inovação radical ou } \\
\text { incremental, casa } \\
\text { própria, infra- } \\
\text { estrutura ou } \\
\text { agricultura }\end{array}$ & $\begin{array}{l}\text { Filtros iniciais, } \\
\text { elaboração de plano } \\
\text { de negócios com } \\
\text { informações } \\
\text { quantitativas e } \\
\text { qualitativas }\end{array}$ & $\begin{array}{l}\text { Predomínio de análise } \\
\text { individual com } \\
\text { informações } \\
\text { quantitativas. Pouca } \\
\text { influência das unidades } \\
\text { do exterior }\end{array}$ & $\begin{array}{l}\text { Retorno e } \\
\text { alinhamento } \\
\text { estratégico }\end{array}$ \\
\hline WEG & $\begin{array}{l}\text { Novo produto, } \\
\text { manutenção, } \\
\text { aplicação, } \\
\text { otimização, novas } \\
\text { tecnologias ou } \\
\text { materiais } \\
\end{array}$ & $\begin{array}{l}\text { Filtros dos gerentes, } \\
\text { análise qualitativa na } \\
\text { Comissão de } \\
\text { Portfólio }\end{array}$ & $\begin{array}{l}\text { Predomina análise } \\
\text { individual. Forte } \\
\text { influência das unidades } \\
\text { do exterior. Considera as } \\
\text { tecnologias disponíveis }\end{array}$ & $\begin{array}{l}\text { Alinhamento } \\
\text { estratégico, } \\
\text { disponibilidade de } \\
\text { recursos }\end{array}$ \\
\hline
\end{tabular}




\subsection{ACOMPANHAMENTO DOS PROJETOS E REVISÕES DO PORTFÓLIO}

Uma vez que as empresas já possuem um portfólio de projetos, é preciso fazer o seu acompanhamento. Na verdade, uma vez iniciado, o processo de gestão do portfólio de projetos nunca termina, a menos que a empresa pare de desenvolver novos produtos ou encerre suas atividades. Nessa seção serão apresentados os principais mecanismos pelos quais a ALFA, a BETA, a TIGRE e a WEG acompanham seus projetos. Os processos de gestão do portfólio dos modelos teóricos incluem o acompanhamento e a revisão dos projetos, para avaliar quão bem estão se desenvolvendo frente a indicadores individuais e ao plano estratégico. Periodicamente, os projetos devem ser revisados e validados em relação aos seguintes elementos (PMI, 2006b):

a. Alinhamento dos componentes com a estratégia corporativa.

b. Viabilidade dos componentes como parte do portfólio, baseada em indicadores.

c. Valor e relação entre os componentes.

d. Disponibilidade de recursos e prioridades do portfólio.

e. Adição e exclusão de componentes do portfólio.

Todas as empresas possuem mecanismos formais para acompanhamento e revisão dos projetos e do portfólio, incluindo mudança de prioridades, cancelamento, suspensão ou adição de projetos. Algumas empresas como a ALFA, a BETA e a TIGRE utilizam indicadores de desempenho para o acompanhamento dos projetos e dos produtos após o lançamento.

\subsubsection{ALFA}

Durante a fase de conversão o acompanhamento dos projetos é constante. Há diversos mecanismos utilizados para o acompanhamento dos projetos, podendo eventualmente alterar sua priorização e os recursos alocados. Além disso, o cenário altamente dinâmico do mercado globalizado muitas vezes impele a empresa a tomar decisões que precisam ser implementadas rapidamente, levando a revisões no portfólio de projetos. De certa forma, a presença na empresa fora do Brasil, por meio de equipes de engenharia e P\&D em todas as suas unidades, torna essa tarefa de manter o portfólio atualizado ainda mais complexa, sendo porém um dos processos recomendados pelos modelos teóricos de gestão do portfólio considerados nessa 
pesquisa. Quando o planejamento para o ano é aprovado e divulgado, os recursos são alocados em todas as unidades. A partir daí, as horas alocadas nesses projetos devem ser apontadas semanalmente pelos desenvolvedores. Segundo um dos entrevistados: "Não é uma forma de garantir que as diretrizes estratégias estejam sendo efetivamente seguidas, mas pelo menos que as pessoas estão trabalhando nos projetos definidos como prioridades".

A área de engenharia da ALFA desenvolveu um software chamado DOCPROJ, disponível na sua intranet, onde podem ser acessados todos os itens de controle dos projetos. Nele é possível acompanhar as informações básicas do projeto, a meta de EVA, a meta de Retorno estimado, o Payback, dentre outras. É possível também comparar o cronograma de referência aprovado no COMEX com o estágio atual. Nesse sistema, que funciona sobre a plataforma Lotus Notes ${ }^{1}$, é possível consultar uma folha de resumo do projeto, um extrato da situação atual com os indicadores principais: investimento, horas gastas, entregáveis em dia, atrasados etc. No sistema está armazenada toda a documentação dos projetos, tais como análises de decisão de cada fase, relatórios, cronograma, atas de reunião, certificação de processos, processos da fábrica, certificações de produto, certificações de fornecedores, relatórios financeiros, toda a história do projeto, situação do EVA, revisões técnicas que foram realizadas, dentre outras. Há também uma folha de recursos onde está a utilização consolidada dos recursos da engenharia para todos os projetos, com todas as pessoas e atividades e onde o tempo delas está sendo alocado. Segundo um dos entrevistados, essa informação não é efetivamente usada para justificar os investimentos no projeto, sendo uma informação de suporte, de controle e acompanhamento se os recursos estão sendo usados conforme o planejado. “Ainda não há um processo formal para a reavaliação do portfólio, ou da prioridade dos projetos. Depende muito do andamento de cada projeto e das decisões estratégicas tomadas ao longo de cada ciclo de planejamento".

Porém, um dos problemas que ocorrem com certa frequiência, constatado durante as entrevistas, é que nem sempre os líderes de projeto atualizam adequadamente o sistema de acompanhamento, resultando em informações incorretas e desatualizadas. O gerente, em caso de dúvida, precisa solicitar a confirmação ou que o líder do projeto atualize o sistema. Esse problema não é encontrado apenas na ALFA e segundo Martinsuo e Lehtonen (2006), é um problema geral nas empresas que desenvolvem produtos, pois os desenvolvedores não atualizam os cronogramas e os bancos de dados ficam desatualizados muito rapidamente quando o ambiente fica mais turbulento. Assim, os sistemas de acompanhamento dos projetos

\footnotetext{
${ }^{1}$ Lotus Notes é um banco de dados cliente-servidor de trabalho colaborativo e e-mail, concebido pela Lotus Software, do grupo IBM Software Group. Fonte: http://pt.wikipedia.org/wiki/Lotus_Notes.
} 
precisam levar em consideração o aspecto comportamental das equipes e oferecer alternativas para o acompanhamento de cada um dos projetos e do portfólio como um todo.

Para os grandes projetos a avaliação é mensal, sendo que para alguns projetos mais críticos, dependendo da fase, o acompanhamento é praticamente diário. Mensalmente, o gerente de marketing e o gerente da engenharia se reúnem para revisar o andamento dos projetos o que acontece também após o lançamento de um novo produto. Cada produto também tem metas acompanhadas pelo marketing, tais como a demanda atual comparada à demanda potencial indicada no plano de negócios do projeto. O departamento de vendas, por sua vez, acompanha como está a aprovação do novo produto pelos clientes, gerando entre outras informações, uma curva de crescimento do produto no mercado. O pessoal da engenharia monitora se o custo alvo do produto está dentro do previsto, se o índice de defeitos está aceitável, e assim por diante.

Após o término de um projeto de desenvolvimento tecnológico, muitas vezes ele não passa imediatamente para o desenvolvimento de novos produtos. Dependendo das necessidades de cada mercado e das decisões estratégicas da empresa, alguns projetos podem ficar engavetados por algum tempo, como no exemplo dado por um dos entrevistados da ALFA:

Na Ásia há concorrentes para determinados subsistemas que utilizam uma tecnologia muito mais cara que a nossa. A ALFA tem uma tecnologia de menor custo porque a nossa expertise em termos de projeto é muito maior e o nosso produto acaba sendo mais eficiente. Porém, mesmo com a tecnologia mais nova estando pronta, vendemos a tecnologia antiga que ainda é melhor que a deles em termos de eficiência energética, em termos de ruído, uma série de vantagens. Por isso não tivemos que lançar a tecnologia mais nova naquele mercado ainda.

O exemplo anterior ilustra a vantagem competitiva obtida pela empresa ao estabelecer como um dos objetivos estratégicos a liderança tecnológica no setor. Mesmo que os concorrentes lancem um produto mais moderno, a empresa ainda terá como responder com sua próxima geração tecnológica que ainda não foi utilizada naquele mercado. Esse é o tipo de resultado previsto pelos modelos teóricos de gestão de portfólio. Outro exemplo foi uma iniciativa global alguns anos atrás para desenvolver novas idéias e novos mercados. Havia a intenção de desenvolver um produto usando uma tecnologia diferente da tecnologia usada atualmente, que é apenas uma das várias tecnologias utilizadas. Chegou-se a desenvolver uma nova tecnologia que não foi lançada porque a empresa concluiu que seria mais vantajoso naquele momento simplesmente continuar com a tecnologia atual. A nova tecnologia está engavetada até hoje. A iniciativa parou em uma fase de projeto detalhado. "Se algum dia fizer 
sentido mercadologicamente, a empresa pode resgatar o projeto, finalizá-lo e colocá-lo em produção", como comenta um dos entrevistados. Existem casos também de projetos médios, onde a empresa desenvolveu uma aplicação específica para determinados mercados para participar de uma concorrência global. No final, o composto produto, preço, promoção e prazo, os 4P's da concorrência, foram melhores.

Para que um novo projeto seja iniciado segue-se o mesmo processo utilizado para composição do portfólio durante o ciclo de planejamento anual. A primeira fase, de Ideation, aprova a idéia para o projeto poder começar formalmente. Em uma segunda fase, de concepção, o conceito é desenvolvido, detalhado. Para seguir adiante vai exigir mais investimentos, portanto, ao final dessa fase, ele é apresentado para a diretoria para aprovação. Se aprovado nessa análise, o projeto passa para a fase de conversão (que é o desenvolvimento do projeto, dos protótipos propriamente ditos). Após a conversão, se os protótipos forem aprovados, o projeto segue para a fase de execução e ao final do processo, mais uma avaliação para o seu fechamento. Segundo um dos gerentes entrevistados, nas fases de concepção e conversão é mais comum ocorrerem possíveis redirecionamentos, podendo até mesmo haver o cancelamento de um projeto. É desejável que apenas os projetos com maior probabilidade de sucessos técnico e comercial passem para as fases seguintes, prática que está de acordo com os modelos teóricos de gestão do portfólio, em especial de Cooper et al. (1997).

\subsubsection{BETA}

Como o PGD tem um horizonte de vários anos, é comum que projetos previstos no seu lançamento não sejam desenvolvidos. Devido às mudanças no cenário econômico, nas necessidades dos clientes e também à evolução tecnológica, alguns projetos são cancelados, outros são adiados e principalmente, novos projetos são incluídos. $\mathrm{O}$ acompanhamento dos projetos do portfólio é realizado tanto no nível tático quanto no nível estratégico. No nível tático, cada coordenador convoca reuniões periódicas, mensais ou até mesmo semanais, com os desenvolvedores e outros membros da equipe do projeto para verificar o andamento das tarefas e eventualmente resolver problemas relacionados a conflitos de recursos compartilhados com outros projetos. Nesse nível, o coordenador mantém um cronograma de projeto atualizado, além de informações detalhadas sobre a pontualidade das tarefas, o uso de recursos, dentre outras. Semanalmente, todas as segundas-feiras, o responsável pela qualidade 
interna da Divisão de Desenvolvimento envia um e-mail a todos os coordenadores de projetos solicitando a atualização de seus cronogramas. Esse mecanismo parece resolver o problema encontrado na ALFA para atualização dos dados no sistema.

A transição do nível tático para o nível estratégico ocorre por meio de um fórum chamado Masterplan. Esse fórum reúne todos os gerentes de grupos e o diretor em uma reunião periódica para atualização da estratégia tecnológica da empresa e verificação de continuidade do alinhamento estratégico dos projetos. O Masterplan também é um documento que lista todos os projetos ativos, tanto os projetos listados no PGD quando os projetos de OS especiais, sendo usado como referência para o acompanhamento do portfólio de projetos. Ele contém as datas dos principais marcos de cada projeto, que são atualmente três:

a. Aprovação do DRE: marca o inicio do desenvolvimento do projeto.

b. Aprovação do protótipo: marca a aprovação do protótipo e continuidade no desenvolvimento do projeto. É possível que o projeto seja cancelado ou adiado se o protótipo não for aprovado.

c. Aprovação do DRS: marca o final do desenvolvimento, quando o projeto efetivamente está pronto para se transformar em produto.

As reuniões para revisão do Masterplan ocorrem a cada três ou no máximo a cada seis meses. Nessa reunião, os gerentes apresentam a situação dos projetos sob sua responsabilidade e discutem atrasos, mudanças de prioridade, cancelamento ou inclusão de novos de projetos. O diretor da divisão tem a responsabilidade de manter o direcionamento estratégico de longo prazo previsto no PGD, bem como de mediar possíveis problemas quando à alocação de recursos entre os diversos grupos. Cada projeto é analisado em termos de seu andamento, performance, recursos utilizados, riscos e conflitos. Além disso, nesse momento são consideradas as mudanças de cenário interno e externo da empresa, possibilitando a esse grupo redefinir as prioridades, podendo até mesmo pausar a execução de algum projeto, liberando recursos para outros, ou ainda propor um cancelamento. Não e comum o cancelamento de projetos após o inicio do desenvolvimento, sendo mais frequiente alterações de escopo e modificação de prazos. O cancelamento de projetos é algo raro na BETA, apesar de já ter acontecido, tanto em pequenos projetos quando em projetos de novas tecnologias. Contudo, devido à cultura de inovação presente na empresa, essa é uma situação tratada com absoluta normalidade.

Além das reuniões do Masterplan há também reuniões pontuais para discutir o andamento dos projetos. Essas reuniões, convocadas pelos coordenadores de projetos, são os mecanismos usados para aprovação de protótipos, análises críticas de testes de validação, 
alterações em requisitos e prazos, dentre outras mudanças. Entre os participantes dessas reuniões estão representantes das áreas envolvidas com o estágio do projeto naquele momento. Registros destas análises são mantidos em atas de reuniões, sendo que as análises críticas do projeto resultam muitas vezes em alterações dos requisitos de entrada (DRE), ou no planejamento (DPL). Nestes casos o documento afetado é revisado pelo coordenador e aprovado novamente pela diretoria.

A finalização de cada projeto corresponde a uma fase de validação, que é planejada e executada de forma a assegurar que o produto resultante seja capaz de atender à aplicação especificada ou uso intencional, quando conhecido. Estas atividades são planejadas pelo coordenador do projeto com a elaboração de um plano de testes e podem ser executadas por diversos setores da empresa (Engenharias de Aplicações, Assistência Técnica, Controle da Qualidade ou outros), ou em plantas piloto com a concordância do cliente. Ao final desta fase é elaborado o Documento de Resultados de Saída do projeto (DRS), contendo os resultados obtidos no desenvolvimento, tais como especificações técnicas, normas e legislações atendidas, características críticas para o funcionamento apropriado e seguro do produto, pontos fortes de marketing, dentre outros. Este documento é elaborado pelo coordenador do projeto e submetido a análise crítica para aprovação final pelos representantes da empresa, preferencialmente o mesmo grupo que participou da discussão e aprovação do respectivo DRE. As atividades desta fase englobam as seguintes etapas: elaboração de um plano de testes; execução de todos os testes previstos; elaboração do DRS; reunião de análise crítica e aprovação final. Na reunião de aprovação as divergências em relação ao DRE são apontadas. Normalmente, após a finalização da validação os procedimentos de fabricação estarão em fase final de conclusão, e por este motivo a aprovação do DRS representa a transferência do processo de projeto e desenvolvimento para os demais processos da empresa, tais como setores produtivos, comerciais, marketing, engenharias de aplicações, dentre outros.

Após a aprovação do DRS segue-se uma reunião para análise crítica dos resultados, que pode contar com integrantes de toda a empresa, no caso de um projeto iniciado por um DRE, ou apenas com integrantes da Divisão de Desenvolvimento para projetos iniciados por um Estudo Técnico. Com relação à gestão do portfólio, esse momento indica a liberação de recursos que podem ser alocados para outros projetos. A partir daí, é possível também acompanhar a performance do novo produto em termos de retorno do investimento realizado. Para isso a empresa utiliza, desde 2006, um indicador chamado Indicador de Retorno do Investimento (IRI), que leva em conta o número de horas gastos no desenvolvimento e na manutenção do projeto, o tipo de projeto (hardware ou software) e o custo médio da hora na 
divisão de desenvolvimento, arbitrado pela diretoria e informado aos coordenadores de projetos. O uso desse tipo de indicador para acompanhamento da performance do produto está em acordo com os modelos teóricos, especialmente do PMI (2006b). Essa prática aponta na direção de uma melhoria no processo de gestão do portfólio da BETA. Porém, a ausência de um plano de negócios mais elaborado ou de informações sobre o retorno esperado no DRE impedem que a empresa compare o retorno obtido com a performance real do produto e como conseqüência torna-se difícil aperfeiçoar o processo de planejamento.

\subsubsection{TIGRE}

Para o gerenciamento dos projetos, registro das informações básicas (escopo) e seu acompanhamento (cronograma), o departamento usa um software de controle de projetos ${ }^{1}$, que também oferece suporte específico à GPPNP, porém não é utilizado. O gerente de PD\&E elabora um relatório quinzenal consolidando as informações dos indicadores de prazos, custos e detalhando o progresso no desenvolvimento de cada projeto ativo. Esse relatório apresentado nas reuniões de revisão, que podem, dependendo do andamento do projeto, decidir por cancelar, adiar ou iniciar novos projetos.

Em termos de indicadores de acompanhamento, a TIGRE usa muito o próprio cronograma de atividades e entregáveis, onde é verificada a diferença (em dias) entre cada fase do processo, por exemplo, quantos dias foram gastos entre as fases P3 e P4. Esse é um dos indicadores de acompanhamento dos projetos e de acordo com o tipo de produto, há objetivos de prazos máximos, planejados também de acordo com o histórico dos projetos. $\mathrm{O}$ líder do projeto é responsável por manter esses indicadores atualizados. A área de PD\&E é a responsável por coletar as informações junto aos líderes de projeto, ou no sistema, e elaborar esse relatório consolidado de todos os projetos. Com relação ao cancelamento de projetos procura-se reunir o máximo possível de informações nas etapas anteriores, avaliando cuidadosamente as probabilidades de sucesso técnico e comercial como recomendam Cooper et al. (1997).

\footnotetext{
${ }^{1} \mathrm{O}$ nome do software foi omitido a pedido da empresa.
} 


\subsubsection{WEG}

Reuniões mensais são agendadas para acompanhamento dos projetos, mas normalmente ocorrem encontros menos formais, semanalmente, entre os gerentes de líderes de projeto para atualização das informações. Atualmente o acompanhamento é realizado por meio de cronogramas e de uma planilha, baseada no PWQP, com todos os projetos no portfólio previstos para o ano, os ativos, suspensos, cancelados e ainda não iniciados. O acompanhamento do prazo dos entregáveis de cada projeto é o mais importante em geral, além dos investimentos que estão sendo realizados, mas não existe ainda um apontamento detalhado de custos para cada projeto, somente do uso de recursos humanos, da disponibilidade das pessoas. Assim, não é possível atualmente apontar um custo de desenvolvimento final preciso para o projeto. Segundo um dos gerentes de engenharia, até 2005 isso era uma necessidade que estava sendo montada com planilhas e cronogramas, porém, com a implantação do SAP a partir de 2007, esse trabalho foi descartado, como conta um dos gerentes:

Quando começamos a usar SAP, todo o planejamento foi refeito. Agora, eu sou coordenador dessa equipe e também sou líder do processo de engenharia. Então, estamos redesenhando todo esse planejamento dentro do SAP.

Ainda segundo o gerente, uma das ferramentas que será usada inicialmente será o planejamento por cronogramas. A base de dados do SAP será unificada para todas as unidades da empresa no mundo todo. Dessa forma, será possível elaborar o planejamento integrado de todas as atividades, de todos os grupos de engenharia das outras fábricas também, com o apontamento de horas trabalhadas em cada projeto, as listas de materiais, o planejamento de produção e tudo mais no projeto.

No caso dos projetos com melhorias incrementais ou alterações específicas, desenvolvidos na engenharia de produtos, não há indicadores individuais para cada projeto que apontem a performance no desenvolvimento daquele projeto. Há o percentual que já foi completado, mas não é muito confiável, segundo os gerentes entrevistados. "É difícil dizer qual o percentual realizado exatamente de cada atividade", completa um dos gerentes. Para os projetos de novos conceitos ou tecnologias, desenvolvidos pelo departamento de $\mathrm{P} \& \mathrm{D}$, o acompanhamento também é realizado por reuniões, utilizando os marcos principais de cada projeto e as datas de conclusão das tarefas (entregáveis). Como observa um dos gerentes: "Se você olhar um projeto, o nosso software vai indicar, por exemplo, que está $60 \%$ concluído. 
Mas se eu conversar com o desenvolvedor pessoalmente, ele pode não ter segurança de me dizer que está $60 \%$ pronto".

O fato da WEG não possuir indicadores de performance durante o desenvolvimento do projeto implica em problemas no atendimento dos prazos, de forma muito similar ao que ocorre na BETA. Se a empresa não consegue identificar atrasos e potenciais problemas com antecedência, as ações corretivas acabam tendo impacto em outros projetos comprometendo a performance de todo o portfólio. Se um atraso significativo for identificado de forma tardia, provavelmente a empresa terá que remanejar recursos de projetos com menor prioridade para tentar "apagar o incêndio". Esse efeito é discutido por Repenning (2001), que aponta o aprendizado organizacional obtido com a gestão do portfólio como fator fundamental para se evitar ou minimizar esse efeito do "apaga incêndio" no desenvolvimento de novos produtos. Os projetos de desenvolvimento de novos produtos devem ser utilizados também para criar capacidades competitivas de longo prazo. As capacidades ou competências resultantes podem ser, e frequientemente o são, mais importantes até que o próprio produto final. Apesar de haver potencial para uma organização melhorar a performance do desenvolvimento, a maioria das organizações pode aprender ainda mais com as suas próprias experiências. Porém, para que isso ocorra, é fundamental que os projetos sejam acompanhados por meio do uso de indicadores, como sugere também o PMI (2006b).

No departamento de P\&D é utilizada uma ferramenta desenvolvida internamente chamada Programa de Gerenciamento das Atividades (PGA). Esse programa é aberto a todos os gerentes ou qualquer outro funcionário, que pode ver as informações sobre as atividades em andamento nos projetos. O PGA gerencia não só os projetos, mas todas as atividades do departamento como, por exemplo, visitas a clientes ou outras atividades externas. É possível gerar um relatório indicando quanto tempo cada pessoa dedicou a cada atividades durante o mês. Isso pode ser usado posteriormente para justificar os investimentos nos projetos, segundo o gerente entrevistado. Existe no P\&D um indicador global de eficiência e eficácia dos projetos. Mensalmente é possível avaliar o percentual de trabalho concluído dentro do prazo estimado, o que indica a eficácia do departamento e os trabalhos concluídos com algum atraso, que correspondem ao indicador de eficiência. Para essa atividade de acompanhamento de projetos, eficiência é concluir o trabalho e eficácia é concluir dentro do prazo.

Nas reuniões de acompanhamento os participantes discutem tecnicamente os projetos, gerando documentos que podem muitas vezes resultar em revisões no cronograma, nas prioridades ou até mesmo propor o cancelamento em casos onde o projeto não foi bem pensado ou quando se encontram muito mais dificuldades do que as previstas no início. Essa 
reunião acontece mensalmente e a equipe decide se o trabalho será cancelado ou não, se agora vai ser mais ou menos prioritário que o outro. Mudanças de prioridades e chaveamento de pessoas entre projetos são assuntos tidos como complicados pelos gerentes. Um dos exemplos citados no departamento de $\mathrm{P} \& \mathrm{D}$ foi a transferência de três pessoas de suas atividades programadas, com o cancelamento de alguns trabalhos, para que eles participassem de outra equipe. A estratégia do gerente é conversar com as pessoas, explicar a real necessidade e convencê-los da importância dessa mudança. Essa atitude de esclarecimento e convencimento do pessoal é considerada importante na WEG e reflete o reconhecimento da gerência de que essas transferências entre projetos afetam significativamente a produtividade. A postura de discutir abertamente as decisões facilita muito nos momentos de mudanças de planos, além de ser é importante ter um ambiente aberto de trabalho e explicar sempre o que está acontecendo, como conta o gerente de P\&D.

Durante o desenvolvimento dos projetos há uma constante reavaliação de riscos, podendo eventualmente levar algum projeto à suspensão ou cancelamento. Se um projeto eventualmente não dá certo na etapa de investigação de conceito no departamento de $\mathrm{P} \& \mathrm{D}, \mathrm{o}$ projeto pode ser cancelado. Há inúmeros casos ao longo da história da empresa, como relatam os gerentes. A engenharia de produto é responsável por avaliar o risco de aplicar um novo conceito em um componente ou produto. Essa investigação se desdobra, muitas vezes, em novos projetos, que podem ser cancelados por se tornarem inviáveis tecnicamente ou ainda, se

o detalhamento econômico-financeiro evidenciar que o Payback não atenderá o prazo máximo.

\subsubsection{Resumo comparativo do acompanhamento e revisão do portfólio}

Finalmente, na dimensão de revisão e controle, os projetos que estão em desenvolvimento devem acompanhados. De acordo Rabechini Júnior, Maximiano e Martins (2005), espera-se que o gerente do portfólio, ou quaisquer outros responsáveis pelo seu acompanhamento, se encarreguem de propor reuniões de acompanhamento onde os gerentes, líderes ou coordenadores de projetos devem fornecer informações indicativas do andamento de cada projeto. Com base nestes dados, decisões podem ser tomadas para alteração na constituição do portfólio. As informações de andamento dos projetos, na forma de indicadores servem para as análises e reavaliações. Essa etapa marca também o lançamento de produtos, uma vez que o portfólio na verdade nunca é finalizado, pois sempre deve haver novos projetos 
sendo iniciados, de acordo o modelo proposto por Archer e Ghasemzadeh (1999). As principais características com relação ao acompanhamento dos projetos e revisões no portfólio estão resumidas no quadro seguinte:

\begin{tabular}{|c|l|l|}
\hline EMPRESA & \multicolumn{1}{|c|}{ ACOMPANHAMENTO } & \multicolumn{1}{|c|}{ REVISÕES DO PORTFÓLIO } \\
\hline ALFA & $\begin{array}{l}\text { Indicadores econômico-financeiros, EVA, } \\
\text { cronograma dos entregáveis }\end{array}$ & $\begin{array}{l}\text { Demandas de clientes, mudanças nos } \\
\text { objetivos estratégicos, desdobramento de } \\
\text { projetos }\end{array}$ \\
\hline BETA & $\begin{array}{l}\text { Cronogramas, Masterplan, reuniões entre } \\
\text { os gerentes de grupos e o diretor de } \\
\text { desenvolvimento }\end{array}$ & $\begin{array}{l}\text { Revisões no PGD, OS especiais, pedidos } \\
\text { da diretoria }\end{array}$ \\
\hline TIGRE & $\begin{array}{l}\text { Cronograma e relatórios quinzenais } \\
\text { elaborados pelo departamento de PD\&E }\end{array}$ & $\begin{array}{l}\text { Solicitações da diretoria, revisões no } \\
\text { planejamento estratégico, propostas de } \\
\text { clientes }\end{array}$ \\
\hline WEG & $\begin{array}{l}\text { Reuniões mensais para acompanhamento } \\
\text { do cronograma de entregáveis do PWQP }\end{array}$ & $\begin{array}{l}\text { Mudanças estratégicas solicitadas pela } \\
\text { diretoria, propostas de clientes }\end{array}$ \\
\hline
\end{tabular}

Quadro 14 - Resumo comparativo do acompanhamento e revisão do portfólio

\subsection{ANÁLISE COMPARATIVA DOS CASOS}

A análise comparativa dos casos foi realizada por meio da identificação das práticas de gestão de portfólio de projetos de novos produtos nas empresas, analisando as descrições dos processos de gestão. As práticas identificadas foram então comparadas com cada um dos modelos teóricos de forma a verificar o nível de aderência com cada modelo. Em seguida, foram descritas as principais influências que as unidades do exterior exercem no processo de gestão das matrizes.

\subsubsection{Práticas de gestão identificadas nas empresas}

A análise para os processos principais descritos pelas empresas foi direcionada para os processos principais, chamados processos agregados. Dessa forma, a identificação e o mapeamento das práticas de gestão nas empresas foram realizados determinando-se em qual processo cada atividade identificada se enquadrava melhor. Por meio dessa análise, foram identificadas 50 práticas de gestão, divididas nos três processos básicos definidos com base na 
intersecção dos modelos teóricos de gestão de portfólio. Todas as práticas de gestão listadas a seguir representam ações administrativas ligadas diretamente ao processo de gestão de portfólio de projetos de novos produtos nas empresas.

As seguintes práticas de gestão, relacionadas ao planejamento estratégico, foram identificadas entre as empresas:

1. Elaborar um plano estratégico formal com objetivos claros: a empresa elabora e divulga internamente um plano estratégico que inclui o desenvolvimento de novos produtos e novas tecnologias, informando a todos os interessados as diretrizes e objetivos da empresa, com a participação das unidades do exterior. Esse planejamento deve ter objetivos claros para orientar os processo de gestão do portfólio.

2. Coletar novas idéias de forma abrangente: possui canais internos e externos formalizados com fornecedores, clientes, parceiros e funcionários e terceiros para captação de idéias para novos produtos, incluindo novas idéias especificamente para produtos voltados ao mercado externo, captadas por meio de suas unidades no exterior.

3. Manter um registro formal das novas idéias: possui um banco de dados ou outro tipo de registro onde são armazenadas todas as idéias sugeridas pelos canais internos e externos.

4. Pré-selecionar as idéias usando critérios claros: filtrar as oportunidades de negócio, selecionando entre todas as idéias registradas apenas aquelas que apresentam potencial real para a empresa, com base em critérios nem sempre claros ou pré-definidos.

5. Designar pessoa ou equipe dedicada para a gestão do portfólio: uma ou mais pessoas são responsáveis, de forma fixa, pelas tarefas de coleta e distribuição de informações, convocação das reuniões, redação e distribuição de relatórios, publicação de informações internas sobre o andamento de projetos e outras atividades relacionadas ao processo de gestão do portfólio.

6. Formar equipe esporadicamente para a gestão do portfólio: existem pessoas ou equipes responsável por outras atividades que se reúnem de forma intermitente para executar as atividades administrativas relacionados à GPPNP.

7. Concentrar as atividades de gestão de portfólio no departamento de P\&D: as principais atividades relativas à gestão do portfólio de projetos de novos produtos são atribuídas ao departamento de desenvolvimento de produto e/ou P\&D.

8. Distribuir as atividades de gestão de portfólio entre departamentos: a estratégia da empresa caracteriza a distribuição das responsabilidades pela gestão do portfólio entre 
diversas áreas, por exemplo, engenharia, marketing, escritório de gerenciamento de projetos (PMO), vendas etc.

9. Definir objetivos estratégicos para novos produtos e tecnologias: o planejamento define explicitamente objetivos de redução de custo, liderança tecnológica, entrada em um novo mercado, melhoria de performance, aumento de retorno ou qualquer outro objetivo que possa direcionar a seleção de novos projetos.

Em comparação com atividades sugeridas pelos modelos teóricos, observa-se que as empresas investem um grande esforço na captação e filtro de novas idéias, em especial a TIGRE e a ALFA. Ficou evidenciado pelos processos descritos que essas duas empresas conferem grande importância à dimensão de preparação para a formação do portfólio, conforme o modelo de Rabechini Júnior, Maximiano e Martins (2005). Apesar da BETA elaborar um planejamento para novos produtos, não há evidência de que esse planejamento esteja ligado aos objetivos estratégicos da empresa. Com relação à WEG, apesar do grande esforço no mapeamento das novas idéias e necessidades de seus clientes, a empresa não apresentou mecanismos claros para conectar os projetos aos seus objetivos estratégicos. A participação das unidades estrangeiras no planejamento estratégico da WEG e da ALFA ficou evidente, especialmente daquelas que possuem equipes próprias de $\mathrm{P} \& \mathrm{D}$, o que não acontece com tanta intensidade na TIGRE e praticamente não foi observado na BETA.

As seguintes práticas de gestão foram identificadas nos processos de formação do portfólio:

1. Incluir a alta gerência e diretoria nas fases iniciais do processo: é freqüente a participação da alta gerência ou diretoria nas fases iniciais de avaliação e seleção dos projetos.

2. Elaborar um plano de negócios para cada projeto antes da avaliação: organiza e documenta as informações disponíveis para avaliação do projeto, tais como origem da idéia, sua descrição, potencial de mercado, custo estimados, posicionamento em relação a concorrência, estimativa de tempo para o desenvolvimento do produto, tecnologias envolvidas, impactos, relações com produtos existentes etc.

3. Filtrar as informações para evitar sobrecarga no processo decisório: usando critérios claros, tais como orientação estratégica, permite garantir a qualidade da informação passada adiante. Esses filtros têm a função principal de garantir que informações incorretas, tais como previsões irreais de demanda, não contaminem a avaliação dos projetos. Segundo a WEG é um dos processos mais importantes para permitir a tomada de decisão correta. 
4. Categorizar os projetos: divide os projetos entre categorias para permitir uma comparação mais detalhada entre os projetos de mesma categoria. Por exemplo, projetos de novas tecnologias, projetos para o mercado doméstico e projetos para o mercado industrial.

5. Definir critérios claros para avaliar os projetos: a empresa estabelece critérios claros e objetivos para pontuar ou classificar cada tipo de projeto.

6. Definir um orçamento único para todos os projetos: há um único orçamento que e distribuído entre todos os projetos do portfólio de acordo com sua prioridade.

7. Definir um orçamento por categorias de projetos: há um orçamento para cada categoria de projetos, sendo que os recursos são distribuídos de acordo com a priorização em cada categoria, independentemente da prioridade do projeto com relação aos projetos das outras categorias.

8. Considerar a capacidade atual da equipe de desenvolvimento: levar em conta, durante a análise e seleção dos novos projetos, as competências atuais em termos de recursos humanos disponíveis na empresa, isto é, se é possível desenvolver os novos projetos com as pessoas disponíveis ou se será preciso contratar ou terceirizar etapas do projeto. Essa prática permite identificar com antecedência os gargalos de recursos humanos para os projetos, tanto em quantidade como em especialidade.

9. Considerar os ativos tecnológicos atuais da empresa: significa que, durante o processo de análise e seleção dos projetos, as tecnologias já dominadas disponíveis na empresa são explicitamente levantadas e avaliadas como opções tecnológicas. Dessa forma os participantes do processo têm informações mais detalhadas sobre as tecnologias que serão necessárias para o desenvolvimento do projeto, se será necessário desenvolver alguma, comprar, licenciar, dentre outras opções.

10. Planejamento os recursos necessários: quando possível, procura listar os recursos necessários, identificando aqueles disponíveis na organização e aqueles que eventualmente devem ser desenvolvidos, adquiridos, alugados etc, antes da avaliação e seleção dos projetos.

11. Uniformizar os critérios de avaliação dos projetos: todos os projetos são analisados levando-se em conta as mesmas informações e os mesmos critérios para avaliação, comparação, seleção e priorização. Caso a empresa faça a categorização dos projetos, os mesmos critérios devem ser usados para os projetos de cada categoria.

12. Autorizar o início de projetos sem análise do portfólio: ocorre principalmente em empresas menores ou com poucos acionistas, onde um projeto pode ser empurrado adiante 
devido ao patrocínio de alguém com pode de decisão suficiente, mesmo que sem as informações necessárias para comparação com outros projetos.

13. Envolver diversas áreas da empresa: outras áreas participam colaborando no processo de decisão, por exemplo, o departamento de vendas apenas fornece uma previsão de vendas e tamanho potencial do mercado, representantes da fábrica analisam a montagem de novas linhas de produção, representantes de RH verificam as necessidades de recursos humanos e assim por diante.

14. Avaliar os projetos usando a experiência das pessoas envolvidas: essa pratica representa a predominância da analise por meio de inferências e suposições das pessoas mais experientes, que conhecem muito bem o mercado e o produto. Ainda que sejam usadas ferramentas financeiras ou qualitativas, a experiência dos gestores é determinante.

15. Avaliar os projetos usando índices financeiros: uso freqüente de indicadores financeiros tais como VPL, Payback, EVA, ROI, dentre outros.

16. Avaliar os projetos usando ferramentas qualitativas: representa o uso de ferramentas qualitativas para analise dos projetos, sendo caracterizada pelo uso de mecanismos de pontuação, como gráficos de bolhas.

17. Utilizar gráficos na avaliação dos projetos: na avaliação e seleção dos projetos os gestores utilizam gráficos de bolhas ou qualquer outro tipo de gráfico que permite comparar visualmente os projetos segundo critérios pré-definidos.

18. Avaliar as sinergias entre os projetos: a empresa avalia a interação entre os projetos, verificando possível interferências positivas e negativas devido à execução simultânea dos projetos, ao compartilhamento de recursos, à competição pelo mesmo mercado etc.

19. Avaliar o risco do projeto: procura quantificar, mesmo que de forma qualitativa, as probabilidades de sucesso técnico e comercial de cada projeto, levando essas informações em consideração na avaliação e seleção dos projetos.

20. Avaliar o risco do portfólio: procura avaliar o impacto de um projeto nos demais, tanto naqueles em andamento como em outras propostas, e até mesmo em produtos já comercializados (canibalismo, substituição etc).

21. Avaliar o alinhamento estratégico: essa avaliação determina principalmente a prioridade na execução do projeto, uma vez que permite aos gestores determinar quais projetos são mais importantes em um determinado momento com relação aos objetivos estratégicos. Como os objetivos estratégicos da empresa mudam com o tempo, as prioridades dos projetos também podem mudar para se manter o alinhamento do portfólio. 
22. Usar histórico dos projetos anteriores: durante a analise e avaliação das propostas de novos projetos se utiliza ativamente informações de projetos anteriores como referencia para os dados apresentados, sempre que possível.

23. Dividir o processo decisório em fases: estabelecer fases para o processo de formação do portfólio, tais como: concepção, conversão, execução. À medida que o projeto avança pelas fases ele é reavaliado, o que pode causar sua parada temporária ou mesmo cancelamento.

24. Reavaliar periodicamente o andamento dos projetos: uma vez que o projeto foi aprovado ele passa por reavaliações posteriores que podem levá-lo a ser cancelado, postergado ou adiantado.

25. Selecionar os projetos por retorno financeiro: usar como principal critério de seleção dos projetos o retorno financeiro.

26. Selecionar os projetos com indicação de patrocinadores: na prática significa pular fases de análise devido à sua importância estratégica e mediante autorização direta de alguma esfera competente. Assim, o projeto pode entrar na lista de projetos ativos e integrar o portfólio sem um maior detalhamento.

27. Selecionar os projetos por alinhamento estratégico: significa que projetos são selecionados por estarem fortemente alinhados com a estratégia da empresa, mesmo que outras informações (retorno, risco) indiquem que o projeto não é o melhor entre os candidatos do portfólio.

28. Buscar o equilíbrio entre diferentes categorias de projetos: a empresa toma ações concretas na seleção dos projetos para balancear o portfólio, incluindo projetos com diferentes objetivos estratégicos, com diferentes horizontes de tempo para o lançamento do produto, diferentes opções tecnológicas e assim por diante.

29. Alocar recursos por prioridade: determinada a prioridade de cada projetos em uma lista única com todos os projetos de acordo com a prioridade definida pelos gestores do portfólio.

As unidades do exterior não participam diretamente da formação do portfólio, apesar de influenciar nas decisões de seleção dos projetos. A partir da internacionalização do P\&D da ALFA e da WEG, essas empresas se viram obrigadas a oferecer soluções voltadas especificamente para cada mercado, o que exigiu uma participação muito mais efetiva das unidades estrangeiras no planejamento tecnológico. Porém, todas as decisões são tomadas pelos gestores da matriz. 
As seguintes práticas de gestão ligadas ao acompanhamento dos projetos e revisões do portfólio foram identificadas entre as empresas:

1. Acompanhar os projetos com relação aos recursos previstos e utilizados: há um acompanhamento freqüente da utilização dos recursos humanos e financeiros alocados para cada projeto.

2. Fornecer informações periódicas sobre cada projeto: existem procedimentos, indicadores ou sistemas de informações usados para quantificar o andamento de cada um dos projetos.

3. Reavaliar periodicamente o portfólio: utiliza informações atualizadas de cada projeto, juntamente com informações estratégicas atualizadas da empresa para avaliar a continuidade, suspensão temporária, cancelamento, mudança de prioridade, mudanças de escopo ou quaisquer outras revisões necessárias no portfólio de projetos.

4. Reavaliar o portfólio em eventos de mudança estratégica: a empresa apresenta flexibilidade para cancelar ou iniciar novos projetos quando ocorrem mudanças significativas no seu ambiente de negócios, por exemplo, entrada de novos concorrentes, catástrofes, alterações na legislação, intervenções governamentais não previstas.

5. Comparar projetos em andamento com projetos novos: existem evidências que a empresa compara novas propostas com projetos já em andamento e caso fique evidente que um novo projeto pode ser mais interessante, cancelamento o anterior.

6. Cancelar ou adiar projetos por mudanças estratégicas: a empresa possui mecanismos de reavaliação que podem levar o projeto a ser cancelado ou adiado em função da mudança nas prioridades dos projetos ou nos objetivos estratégicos da empresa.

7. Mudar prioridade de projetos: monitora as mudanças nas estratégias e possui casos concretos de mudanças de prioridade nos projetos devido a mudanças de cenário interno ou externo.

8. Gerenciar o estresse das equipes: há mecanismos evidentes para gerenciar de forma efetiva o desconforto dos desenvolvedores nos casos de mudanças de prioridade e realocação de recursos entre projetos.

9. Utilizar informações do portfólio no planejamento de recursos humanos: de posse da lista de projetos, a empresa analisa suas necessidades atuais e futuras, planejando novas contratações ou o treinamento dos funcionários com o objetivo de garantir as competências necessárias para execução dos projetos, tanto em quantidade suficiente quanto em tempo hábil. 
10. Auditar os projetos finalizados: para identificar falhas e possíveis melhorias no processo de gestão de portfólio e no próprio processo de desenvolvimento de novos produtos. Nesse contexto trata-se basicamente uma atividade de exercício da gestão do conhecimento e não de uma atividade fiscalizadora.

11. Gerir os novos conhecimentos criados pelos projetos: a empresa apresenta mecanismos e ações no sentido de registrar, analisar e compartilhar novos conhecimentos que eventualmente tenham sido criados com um novo projeto.

12. Avaliar o valor criado pelo portfólio: após o lançamento dos produtos a empresa realiza periodicamente, ou pelo menos uma vez, uma análise para verificar se o projeto criou ou está criando valor com relação às expectativas inicias ou ao plano de negócios usado para a avaliação e seleção inicial do projeto.

Em comparação com atividades sugeridas pelos modelos teóricos, as empresas utilizam muito poucos os indicadores de performance para fazer o acompanhamento dos projetos. Com exceção da ALFA, que calcula o EVA durante o desenvolvimento do projeto, e da TIGRE, que compara o tempo entre das etapas do projeto com um histórico, as demais empresas se limitam a acompanhar os cronogramas de execução, que muitas vezes ficam desatualizados quando os líderes de projetos ou desenvolvedores estão sobrecarregados trabalhando em diversos projetos simultaneamente.

As principais características da gestão de portfólio na ALFA são o seu planejamento estratégico para novas tecnologias e produtos e a organização de seus recursos de desenvolvimento. O retorno financeiro e o alinhamento com os objetivos estratégico são os principais fatores levados em consideração na avaliação e seleção dos projetos. Outro fator altamente positivo apontado tanto pela área de marketing quando de engenharia é que o contato com os clientes contribui para que as decisões sobre novos produtos sejam mais acertadas. Essa interação de mão dupla permite que o cliente vá até a ALFA levar suas necessidades e que o pessoal da ALFA também esteja junto ao cliente observando como atendê-lo da melhor forma possível. A forma como que o grupo de engenharia está organizado é um fator preponderante para o sucesso na flexibilização dos recursos. O fato de a engenharia estar sempre ligada ao mercado e visitar constantemente os principais clientes, permite aos profissionais desenvolverem um sentimento do que o mercado quer, como conta um dos gerentes entrevistados: "Muitas vezes o vendedor não precisa falar, a engenharia se antecipa e já entende o que precisará ser ofertado daqui a um ou dois anos”.

A liderança tecnológica no setor garante posição confortável para que a ALFA buscar novas tecnologias para o futuro. Há projetos em desenvolvimento que entrarão em produção 
somente daqui a dois anos. Os pontos fortes desse histórico de sucesso são: ir ao mercado, inclusive a engenharia, e conhecer as necessidades dos clientes. Há poucos casos de projetos que não deram certo na ALFA, porque muitas idéias são barradas durante as diversas fases do processo. Chegar a ponto do produto ser lançado e não vender é uma coisa muito rara, conforme comenta um dos entrevistados. O fato de a GPPNP ser um processo coletivo na ALFA, obrigando o projeto a passar por diversos fóruns e amadurecer ao longo de diversas fases, transmite confiança aos participantes do processo: "Pode ser que estejamos todos errados, mas decidimos todos juntos e esse é o pacote de projetos que acreditamos que vai dar certo", como conta um dos gerentes entrevistados.

Um fator importante a ser mencionado é a ferramenta na intranet onde estão centralizadas todas as informações do projeto, técnicas, financeiras, comerciais etc. Essa ferramenta é um agente facilitador no processo de GPPNP, uma vez que qualquer pessoa que tenha acesso a esses documentos pode avaliar o andamento do projeto e propor ações de melhoria, cancelamento, identificar sinergias com outros projetos etc. Esse sistema dá visibilidade aos documentos da produção, da qualidade, certificações, manuais, relatórios de desempenho de vendas etc. O sistema não é usado apenas durante a execução do projeto, mas ao longo de todo o ciclo de vida desse produto, incluindo produção, alterações etc. Isso é, sem dúvida, outro diferencial positivo dessa empresa.

Um dos fatores fundamentais na GPPNP da TIGRE é o esforço empregado para ter informações de qualidade chegando do consumidor. Trazer essa informação é um dos papéis do departamento de PD\&E. O mapeamento dessas informações sobre os novos projetos em planos de negócio formais facilita a análise da diretoria, e esse é um dos segredos para que a GPPNP tenha sucesso na TIGRE, como apontam os entrevistados. Para eles, é fundamental ter uma metodologia estruturada e clara. A metodologia facilita a convergência na tomada de decisão. O uso de indicadores financeiros e do SC (Score Card) adaptado é fundamental na sua metodologia. O processo de GPPNP resulta em vantagem competitiva real para a empresa, na medida em que permite reduzir o risco de suas atividades de P\&D. Essa conclusão encontra respaldo no fato da TIGRE ter recebido mais de R\$ 9 milhões da FINEP, só em 2007, para investimentos em P\&D. A concessão desses recursos se deveu, em grande parte, pelo fato da TIGRE ter conseguido convencer a FINEP de que sua estrutura de P\&D atualmente é capaz de reverter os investimentos em produtos de alto valor agregado, como comenta o gerente de P\&D da TIGRE: "Conseguimos convencer o pessoal da FINEP de que somos capazes, de que a TIGRE tem competência para inovar e responder às demandas do mercado Brasileiro e também das nossas exportações". Além da TIGRE, a ALFA também 
tem utilizado recursos de agências de fomento, por meio de incentivos como a Lei da Inovação $^{1}$ e de recursos destinados à pesquisa em instituições e universidades parceiras. A WEG também apresentou uma forte rede de parcerias, enquanto a BETA não evidenciou esse perfil.

O alinhamento com o planejamento estratégico é o primeiro fator determinante na gestão do portfólio de projetos de novos produtos da WEG. Segundo um dos gerentes entrevistados: "É preciso estar sempre alinhado com aquilo que foi definido na diretoria, temos sempre que observar para onde a empresa está indo e quais são os movimentos estratégicos". Apesar do alinhamento estratégico afetar profundamente a engenharia, ao longo da história da WEG esse fator nem sempre foi devidamente considerado no planejamento dos novos projetos. Um dos exemplos citados foi uma decisão tomada pela diretoria de construir uma nova fundição, que deve entrar em operação em 2009. Porém, para que isso seja possível, os projetos dos produtos que serão fabricados nessa nova fundição devem ser finalizados antes da nova fábrica. Como consequiência, todos os projetos relacionados tiveram que ser antecipados, provocando uma repriorização de todo o portfólio, com conseqüente atraso de outros projetos que já estavam em andamento.

Hoje há diversos mecanismos na empresa para realizar esses filtros, o que na opinião de alguns gerentes, pode ser considerada uma grande evolução recente do processo de gestão. Melhorias de fábrica, por exemplo, passam por um filtro de processos nas comissões da própria fábrica. Atualmente, há um filtro de processos que trata a informação, que nunca passa direto para a engenharia. No caso de uma nova idéia, ela passa antes por uma análise do Círculo de Controle da Qualidade (CCQ), que é um grupo da própria área que está propondo a idéia. Quando a lista de sugestões vai para a engenharia, ela já passou por um filtro adequado, evitando também a sobrecarga de informações, como previne Cooper et al. (1997).

Uma das principais causas apontadas para as falhas no processo de gestão do portfólio de projetos de novos produtos na WEG é a falha na identificação das reais necessidades do mercado e no detalhamento das propostas, como afirma um dos entrevistados:

Inúmeras vezes, desenvolvemos linhas de produtos cuja resposta do mercado foi negativa, porque não foram feitas perguntas suficientes no início do processo, não se questionou o mercado, não se foi a fundo na real necessidade e a informação vinha de alguém que avaliou erroneamente a oportunidade.

\footnotetext{
${ }^{1}$ Lei $\mathrm{n}^{\mathrm{o}}$ 10.973, de 2 de Dezembro de 2004, regulamentada pelo decreto $\mathrm{n}^{\mathrm{o}} 5.563$, de 11 de Outubro de 2005, que dispõe sobre incentivos à inovação e à pesquisa científica e tecnológica no ambiente produtivo.
} 
É possível estender a conclusão anterior para a falta de informações mais detalhadas também na fase de análise, avaliação e seleção dos projetos. Uma das grandes virtudes da sistematização do processo de gestão de portfólio de novos produtos é que suas fases e etapas bem definidas levam à adoção de práticas gerenciais objetivas, tais como a introdução de elementos quantitativos na análise dos projetos. Cada área deve estabelecer a dose ideal de informações quantitativas e qualitativas (ARCHER; GHASEMZADEH, 1999; COOPER et al., 1997; PMI, 2006b). Porém, as práticas de gestão encontradas na WEG têm permitido à empresa manter um crescimento sustentado ao longo dos últimos anos, com o efetivo lançamento de novos produtos baseados em melhorias incrementais e em novas tecnologias. As principais virtudes apontadas pelos entrevistados foram as diretrizes estratégicas e as boas idéias conseguidas no ecossistema da empresa. Um das grandes virtudes da empresa ao longo dos últimos anos foi certamente saber traduzir os desejos dos clientes em produtos com alto valor agregado para uma ampla faixa do mercado nacional e internacional, permitindo um maior retorno nos seus investimentos, como explica um dos gerentes:

Eu acho que temos acertado mais com nossas propostas do que com as sugestões de clientes. O cliente tem muitos desejos, mas na maioria das vezes não podemos atender a um cliente só, temos que olhar todo o mercado.

Há uma unanimidade em afirmar que o alinhamento às diretrizes estratégicas e o equilíbrio entre vários tipos de projetos são fatores muito positivos na WEG, pois definem na prática quais projetos receberão os investimentos e acabarão por serem desenvolvidos. Os projetos escolhidos efetivamente espelham essas diretrizes. Já houve casos de fracassos, mas que não chegaram a abalar a confiança no processo decisório. É natural e até esperado, que empresas do porte da ALFA, BETA, TIGRE e WEG, com a extensa linha de produtos que foi desenvolvida ao longo dos anos, tenham no seu histórico algum percentual de projetos que chega ao mercado e não é bem sucedido. Porém, o maior esforço dessas empresas consiste na identificação das oportunidades de negócio, de desejos dos clientes, traduzidas nas propostas de projetos contendo especificações técnicas e informações comerciais.

Para a WEG, a grande dificuldade para tomar a decisão de lançar algum produto é justamente obter informações confiáveis desse mercado. O conhecimento mais profundo sobre quanto o mercado estaria disposto a pagar por aquele produto, qual é a demanda provável e quais as aplicações ou onde aquele produto seria usado, poderiam auxiliar muito na tomada de decisão. Porém, não são informações fáceis ou mesmo possíveis de serem obtidas para todos os projetos, seja por falta de tempo ou por inviabilidade técnica ou econômica. 
Entretanto, apesar de não elaborar um plano de negócios detalhado para cada proposta de projeto, permitindo assim uma comparação mais efetiva, as várias rodadas de discussão coletiva nos CCQ's e na Comissão de Portfólio garantem um amadurecimento das propostas. Quando a lista de projetos é apresentada para a diretoria, a grande maioria é aprovada.

A compreensão da importância e da complexidade dos processos administrativos envolvidos na gestão do portfólio de projetos de novos produtos também levou a WEG a criar funções específicas para ligar os mercados de motores NEMA e IEC às áreas de vendas, marketing, engenharia e P\&D. Dessa forma espera-se um aperfeiçoamento no fluxo de informações e no processo como um todo.

As empresas elaboram descrições sobre cada projeto para facilitar a análise e comparação. No caso da TIGRE e da ALFA, essas descrições são efetivamente planos de negócios detalhados, com informações qualitativas e quantitativas sobre as demandas, investimentos, potencial de mercado dentre outras. No caso da WEG e BETA, os documentos elaborados são mais simples, contendo informações técnicas e apenas eventualmente uma análise mais quantitativa ou comercial. Além disso, as empresas também possuem mecanismos de filtro para as idéias de novos produtos. Esses mecanismos de filtros são normalmente associados às comissões ou grupos que avaliam as idéias quanto aos critérios de alinhamento estratégico, de acordo com os objetivos de cada empresa. Em geral, dois tipos de critérios são tradicionalmente constituídos, os táticos, que avaliam a efetividade dos projetos, e os estratégicos, que se preocupam com o alinhamento dos projetos com os negócios da organização, em acordo com o PMI (2006b).

Os projetos que passaram pelos filtros, ou seja, pelas considerações de caráter estratégico e tático, são os candidatos à formação do portfólio. A etapa de constituição da carteira de projetos visa estabelecer um plano de gerenciamento do portfólio de acordo com o proposto por MARTINO (1993). Dye e Pennypacker (2000) argumentam que durante cada revisão do processo de seleção e de priorização de projetos, especialmente quando há sérios problemas de alocação de recursos, é importante considerar o seguinte:

a. Projetos devem ser similares em tamanho e nível de complexidade.

b. Projetos devem ter relativamente a mesma duração e demandar poucos recursos raros da organização.

c. Projetos devem ser de prioridades similares para permitir o balanceamento na alocação de recursos.

d. Projetos também devem ser de áreas de conhecimento ou tecnologias similares. 
Assim, torna-se vital agrupar os projetos similares em categorias, o que é feito por todas as empresas como parte do esforço inicial de filtragem das idéias e identificação de novas oportunidades, em sintonia com o processo de categorização descrito no modelo de gestão de portfólio do PMI (2006b). A principal função da classificação dos projetos é separálos em categorias relevantes para o negócio, nas quais um conjunto comum de filtros e critérios pode ser aplicado. As categorias são definidas de acordo com o planejamento estratégico para novos produtos e novas tecnologias. No caso da ALFA e da WEG, ficou evidente que o planejamento estratégico define objetivos, que por sua vez, são suportados por projetos alinhados a eles. Quanto à empresa BETA e a TIGRE, não ficou evidente a relação direta entre objetivos definidos no planejamento estratégico e as categorias de projetos, uma vez que também não há divisão orçamentária entre os diversos grupos de projetos. Ainda, segundo o PMI (2006b), a categorização permite à empresa equilibrar os riscos e investimentos entre as diversas categorias e objetivos estratégicos. Esse equilíbrio foi identificado explicitamente nas práticas observadas na ALFA e na WEG, ainda que ns outras empresas isso também seja um dos objetivos do portfólio.

Os departamentos ligados diretamente ao desenvolvimento de produtos são o centro nervoso da gestão de portfólio, o que significa que os gerentes, coordenadores, líderes de projetos e outros cargos analisados contribuem de forma decisiva em todas as etapas, desde a coleta de idéias até a avaliação da performance dos novos produtos. As principais informações sobre as propostas de projetos passam por eles, tais como análises de viabilidade técnica e comercial, prazos, previsão de investimentos, análise de competências necessárias para contratação de pessoal, dentre outras. Esse aspecto foi mais fortemente evidenciado na BETA e na TIGRE, que concentram mais a gestão de portfólios nos departamentos de P\&D.

O conceito de gestão estratégica do portfólio é usado para designar todas as atividades e práticas administrativas que influenciem na seleção e priorização dos projetos de desenvolvimento de novos produtos. Essas atividades levam em conta um horizonte de longo ou médio prazo (trimestrais, anuais) e usualmente são responsabilidade da alta direção. De forma complementar, a gestão operacional (ou tática) do portfólio é o conjunto de atividades de curto prazo (diárias, semanais) relacionadas à alocação de recursos compartilhados entre os vários projetos ativos. Essas atividades são responsabilidade dos gerentes de projetos e de recursos. Os dois conceitos funcionam de forma complementar nas empresas, onde as atividades de estão estratégica fornecem diretrizes para a gestão operacional e a gestão operacional, por sua vez, fornece informações sobre o andamento do portfólio, para 
realimentação do planejamento estratégico (DE MAIO, 1996; PMI, 2006b), como na figura seguinte:

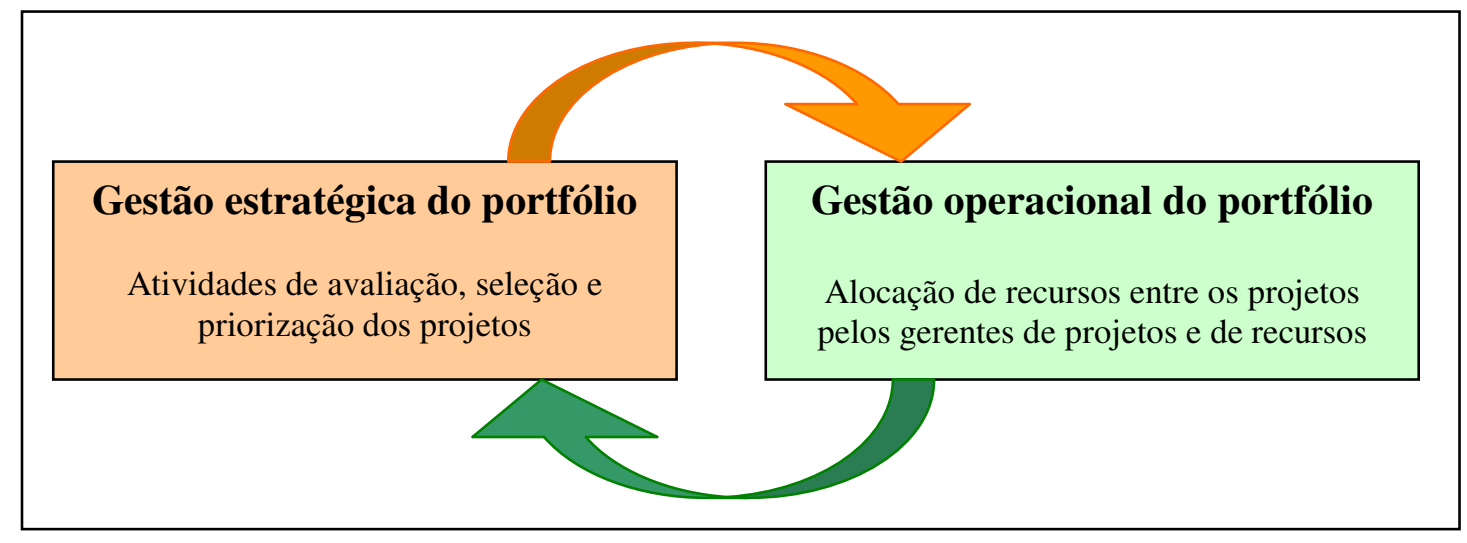

Figura 26 - Interação entre gestão estratégica e operacional do portfólio

Apesar da relativa centralização no $\mathrm{P} \& \mathrm{D}$, em todas as empresas ficou evidente a participação de outras áreas no processo de GPPNP, tais como engenharias, assistência técnica, vendas, produção, marketing, diretoria e alta gerência. O envolvimento da alta gerência e da diretoria é natural e esperado, uma vez que projetos significam investimentos e como tais devem ser aprovados em cada fase do processo. Porém, segundo Utterback (1996), também é fundamental o envolvimento da alta gerência nas fases preliminares do processo de desenvolvimento de produtos, não somente para definir os investimentos e recursos humanos necessários, mas também para identificar potenciais problemas técnicos nos produtos nos processo de fabricação relacionados.

As empresas não utilizam uma técnica ou modelo único na gestão do portfólio de projetos, em acordo com o que afirmam Cooper et al (1999), de que uma abordagem puramente financeira não produz os melhores resultados. Os portfólios de maior sucesso são aqueles obtidos por meio de um modelo híbrido, onde diversas ferramentas são usadas para permitir um tratamento sistêmico ao problema. Na BETA e na WEG é bastante comum que os projetos sejam avaliados usando critérios diferentes, dependendo principalmente da complexidade, da importância estratégica e da quantidade de informações disponíveis. Essa prática vem principalmente da dificuldade na obtenção de informações comuns para todos os projetos, ao mesmo tempo em que muitas vezes os projetos devem ser avaliados e selecionados mesmo que não haja todas as informações disponíveis. Essa prática contesta o que dizem Archer e Ghasemzadeh (1999), que todos os projetos devem ser comparados nas mesmas bases. Porém, a abordagem encontrada nas empresas vai de encontro ao que argumentam Cooper e Edgett (2003) para projetos inovadores, em que a empresa deve usar 
métricas apropriadas e nem todos os projetos podem ser comparados e devem ser avaliados da mesma maneira. Outro exemplo é o caso de demandas não projetadas ou não monitoradas, que podem obrigar a empresa a incorporar uma nova tecnologia ou desenvolver um novo tipo de produto para manter sua posição em um determinado mercado. Na TIGRE foi observada a maior uniformidade nos critérios usados para analisar os projetos.

Dentre as empresas, apenas a ALFA e a TIGRE oferecem evidências do uso freqüente de indicadores financeiros na GPPNP. Elas se valem de indicadores como EVA ${ }^{\circledR}{ }^{1}$, Payback e ROIC para análise, seleção, priorização e acompanhamento dos projetos. Na WEG e na BETA, essa informação é usada se estiver disponível, mas sua ausência não impede que o projeto seja autorizado e desenvolvido, pois nelas predomina a análise qualitativa baseada na experiência dos gestores. Ainda com relação ao uso de indicadores financeiros, a realidade das empresas pesquisadas por Cooper et al. (1999) difere da realidade das empresas desse estudo, uma vez que o principal critério para avaliação, seleção e priorização dos projetos é o alinhamento estratégico. As decisões são tomadas, em geral, no melhor interesse da performance global da empresa, independentemente do impacto individual para os projetos (PMI, 2006b).

Essa realidade nas empresas vai de encontro ao que aponta Cooper et al. (1999) e se deve ao fato de que maioria dos modelos matemáticos historicamente se provou inadequada para o tratamento do risco e incerteza associados aos projetos de desenvolvimento de novos produtos. Dificilmente tratam critérios interdependentes entre múltiplos projetos e falham em reconhecer aspectos do uso compartilhado de recursos e dos objetivos estratégicos. Finalmente, os gerentes percebem que essas ferramentas são difíceis de entender e utilizar.

As empresas não utilizam qualquer tipo de algoritmo para compor um portfólio ótimo, ou um conjunto de projetos que criem o maior valor possível para a empresa, segundo sugerem Archer e Ghasemzadeh (1999) e Blau et al. (2004). A falta de uma base de comparação única, com informações homogêneas entre todos os projetos, pode ser uma das causas. Outro fator mostrado em outras pesquisas é que não há evidências de uso, ou mesmo de interesse pelos executivos, em tais algoritmos ou modelos matemáticos para otimização do portfólio de projetos. Ironicamente, esse tipo de modelo é bastante comum na literatura sobre gestão de portfólios (ARCHER; GHASEMZADEH, 1999; BLAU et al., 2004), mas raramente é encontrado em uso na indústria, como confirma essa pesquisa. Estudos de Cooper et al.,

\footnotetext{
${ }^{1}$ Marca registrada da Stern Stewart \& Co.
} 
1997 comprovam que esse tipo de ferramenta, que dá como resultado uma lista priorizada de projetos, tem uma alta rejeição entre as empresas.

As empresas levam em consideração a sua capacidade de desenvolvimento de produtos ao analisar os novos projetos, tanto em termos de tecnologias novas ou dominadas, quanto em termos de recursos humanos suficientes em quantidade e competências. Assim, a gestão do portfólio de projetos de novos produtos na empresas estudadas tem impacto na administração de recursos humanos, uma vez que o sucesso da carteira depende do desempenho destes, como aponta Rabechini Júnior, Maximiano e Martins (2005). O processo de seleção e priorização nas empresas leva em conta, entre outros fatores, os recursos humanos e técnicos disponíveis para desenvolvimento dos projetos, preocupação que se mostrou bastante evidente na WEG e na ALFA e que estão alinhadas com as atividades sugeridas por Archer e Ghasemzadeh (1999), Cooper et al. (1999), Elonen e Artto (2003) e Cooper e Edgett (2003).

As soluções táticas para os problemas de alocação de recursos entre os múltiplos projetos na ALFA, na WEG e na TIGRE incluem o acompanhamento da alocação dos recursos existentes por meio de análises de capacidade de recursos e do mapeamento mais preciso dos recursos necessários como parte do processo de tomada de decisão em cada fase do processo (COOPER; EDGETT, 2003; ELONEM; ARTTO, 2003). Exceto a BETA, as demais empresas possuem sistemas onde é possível verificar a alocação das pessoas em cada projeto durante o desenvolvimento.

Tanto a ALFA como WEG levam em conta o potencial que o projeto oferece de desenvolver competências críticas para seus objetivos estratégicos de longo prazo. Assim, na avaliação dos projetos, também é levada em consideração como resultados do projeto os novos conhecimentos que podem ser adquiridos e não apenas o valor criado em termos de retorno financeiro. Esses conhecimentos constituem uma forma de capital intelectual da empresa e reforçam o fato de todas as empresas serem líderes absolutas em seus setores. Essas empresas conseguiram, ao longo de sua história, desenvolver uma maior capacidade de inovação e integração no processo de GPPNP, mostrando também competências mais desenvolvidas no desenvolvimento técnico, na engenharia e na compreensão dos seus mercados, fatores importantes segundo Utterback (1996) para o sucesso no desenvolvimento de novos produtos.

Com relação à existência de pessoas designadas especificamente para a gestão do portfólio, como o gestor de portfólio sugerido por Rabechini Júnior, Maximiano e Martins (2005) e pelo PMI (2006b), apenas duas empresas mostraram evidências dessa natureza. A 
WEG está em processo de criar uma estrutura específica para isso, com duas pessoas e a ALFA possui uma equipe que atua de forma similar a um escritório de projetos PMO (PMI, 2004), porém essa equipe atua mais na gestão do desenvolvimento dos projetos do que na gestão do portfólio em si. A BETA e a TIGRE utilizam equipes compostas por membros de várias áreas, especialmente de $\mathrm{P} \& \mathrm{D}$, mas que não atuam exclusivamente com essa finalidade.

As empresas dessa pesquisa não utilizam softwares específicos ou algoritmos para avaliar, pontuar, selecionar ou priorizar seus projetos. Essa constatação é a comprovação prática do que afirmava Cooper et al. (1997), que os executivos de uma forma geral não confiam em fórmulas matemáticas e algoritmos, que eles nem imaginam como funcionam, para decidir por eles, muitas vezes apontando decisões que vão contra a sua experiência prática. Além disso, qualquer que seja o algoritmo ou software, ele ainda dependerá de informações que muitas vezes são imprecisas, incorretas e certamente difíceis de se obter, tais como estimativas de venda, estimativas de custos, de tempo de desenvolvimento, de retorno, sinergia entre os projetos, dentre outras (BLAU et al., 2004).

Em particular, observou-se nas empresas que a avaliação de sinergias entre os projetos é realizada de forma qualitativa, segundo a experiência dos gestores, apenas para evitar sobreposições que sejam mais evidentes entre os projetos. Segundo Blau et al. (2004), o retorno individual dos produtos freqüentemente é influenciado por outros produtos no portfólio e por produtos de competidores. Em alguns casos pode ser até mesmo vantajoso priorizar o desenvolvimento de um novo produto apesar da baixa atratividade financeira e baixa probabilidade técnica de sucesso para promover a criação de uma base de conhecimento que pode catalisar o sucesso de novos produtos que venham a ser desenvolvidos posteriormente.

Ficou evidente entre as empresas que o compartilhamento de recursos é um problema abordado logo nas primeiras etapas de análise dos projetos. A ALFA e a WEG demonstraram uma forte preocupação com esse fator, pois reconhecem os problemas apontados por Clark e Wheelwright (1992) e Evers (2000) devido à sobrecarga dos desenvolvedores por trabalhar em muitos projetos simultaneamente ou por estarem sujeitos a muitas mudanças de prioridade. Essas empresas procuram resolver a questão da alocação de recursos por meio de um planejamento conjunto entre todas as áreas envolvidas, de uma forma sistêmica, e por meio de negociações constantes.

A BETA não apresentou nenhum tipo de software ou planilha onde fosse possível ver o andamento na utilização dos recursos de todos os projetos, enquanto que na ALFA, WEG e TIGRE, há esse tipo de ferramenta. Os sistemas fornecem dados sobre a alocação de recursos 
nos projetos, tais como quanto cada pessoa trabalhou em cada projeto em determinado período. Especialmente na WEG, ficou evidente que os gerentes de engenharia e de P\&D reconhecem que, diferentemente de recursos financeiros ou máquinas, pessoas não podem ser imediatamente transferidas de um projeto para outro sem turbulências. Há uma preocupação constante em gerenciar o estresse das equipes em função das mudanças de prioridade nos projetos. Também foram encontradas evidências que a WEG, a TIGRE e a ALFA procuram usar recursos dedicados para cada projeto, tanto quanto possível. Porém, em casos específicos é indispensável que uma pessoa trabalhe em mais de um projeto ao mesmo tempo. Porém, de acordo com o que recomenda Evers (2000), essas empresas monitoram constantemente a utilização dos recursos para evitar sobrecargas e perda de eficiência. Dentre as empresas, a BETA apresentou o maior compartilhamento de recursos, alocando grande parte de seus profissionais em mais de três projetos ao mesmo tempo.

Apenas na ALFA foram encontradas evidências de uma avaliação de resultados da GPPNP. Essa etapa é responsável por monitorar os resultados obtidos pelo produto e comprálos às previsões elaboradas anteriormente na análise e seleção do projeto. Essa comparação tem o objetivo principal de aperfeiçoar a gestão do portfólio sendo uma oportunidade para a empresa analisar seus erros e acertos, verificar fontes de informação confiáveis ou incorretas e avaliar se os critérios utilizados produziram resultados positivos ou não. Martinsuo e Lehtonen (2006) definem a eficiência na gestão do portfólio como sendo a estimativa dos membros da organização, do sucesso que os projetos obtém juntos, como um portfólio, em atingir os objetivos de alinhamento estratégico, o balanceamento entre projetos e a maximização do valor. Nesse contexto ficou evidente, pelas entrevistas realizadas, que a gestão do portfólio em cada empresa tem espaço para melhorar a avaliação do portfólio.

Essa falta de enfoque na fase final do projeto, e principalmente no pós-lançamento dos produtos, também compromete a gestão do conhecimento. Além disso, confiar apenas nas auditorias e revisões pós-projetos para compartilhar conhecimentos entre projetos pode se provar insuficiente. Usualmente essas atividades são de baixa prioridade e não capturam toda a complexidade do histórico do desenvolvimento de projetos, de acordo com Antoni et al. (2003). Para esses autores, também é necessário reconhecer que múltiplos projetos em uma empresa têm interconexões e garantir que as pessoas passem suas experiências para as outras é um dos grandes desafios para o sucesso de longo prazo do desenvolvimento de produtos. Essa preocupação foi encontrada apenas no P\&D da WEG.

Todas as empresas possuem mecanismos formais para acompanhamento dos projetos e revisão do portfólio. As revisões mais profundas ocorrem pelo menos uma vez ao ano, sendo 
que é comum que ocorram reavaliações trimestrais (BETA), mensais (WEG, ALFA) ou até mesmo quinzenais (TIGRE), o que vai de encontro com o sugerido por Wheelwright e Clark (1993), e o PMI (2006b) que recomendam o estabelecimento de prazos de até um ano para revisão no portfólio e alocação de recursos para os projetos. As reuniões de acompanhamento são o principal mecanismo de revisão e controle usado pelas empresas. Tais reuniões acontecem em geral com a presença de gerentes e diretores dos departamentos de P\&D e eventualmente de outras áreas.

Segundo o PMI (2006b), a falta de suporte organizacional para a GPPNP é um dos grandes obstáculos para seu sucesso, diretamente afetado pelo nível de maturidade da organização. Todas as empresas mostraram evidências da organização como um todo entender a necessidade da gestão de portfólio e comprometer pessoas, processos e ferramentas para torná-lo um sucesso, fatores de extrema importância segundo Elonen e Artto (2003) e Martinsuo e Lehtonen (2006). Nesse aspecto a WEG se destacas ao criar cargos gerenciais especificamente para o suporte à sua GPPNP nas linhas de motores NEMA e IEC.

\subsubsection{Comparação entre as práticas e os modelos teóricos}

A partir das práticas identificadas nas empresas, foram elaboradas tabelas comparativas com os modelos teóricos, com o objetivo de verificar qual o alinhamento entre a gestão em cada empresa e os processos e atividades sugeridos por cada um dos modelos, servindo também como comparação entre as práticas de cada empresa. Essa análise comparativa contribui para o entendimento do processo de gestão de portfólio em cada um das empresas.

\subsubsection{Modelo de Rabechini Júnior, Maximiano e Martins}

Retomando o modelo de gestão de portfólio sugerido por Rabechini Júnior, Maximiano e Martins (2005) descrito no item 2.2.2.1, as suas cinco dimensões foram analisadas para cada empresa, produzindo o quadro resumo seguinte: 


\begin{tabular}{|c|c|c|c|c|}
\hline PROCESSO & ALFA & BETA & TIGRE & WEG \\
\hline Preparação & $\begin{array}{l}\text { Contexto e } \\
\text { objetivos, critérios } \\
\text { e pesos para cada } \\
\text { tipo de projeto }\end{array}$ & $\begin{array}{l}\text { Análise de } \\
\text { oportunidades mas } \\
\text { sem definir critérios } \\
\text { claros }\end{array}$ & $\begin{array}{l}\text { Define objetivos } \\
\text { e critérios, } \\
\text { porém não são } \\
\text { claros }\end{array}$ & $\begin{array}{l}\text { Contexto e } \\
\text { objetivos são } \\
\text { definidos mas } \\
\text { critérios de seleção } \\
\text { não são claros }\end{array}$ \\
\hline Identificação & $\begin{array}{l}\text { Lista de projetos } \\
\text { com riqueza de } \\
\text { informações }\end{array}$ & $\begin{array}{l}\text { Lista de projetos } \\
\text { porém com poucas } \\
\text { informações }\end{array}$ & $\begin{array}{l}\text { Lista de projetos } \\
\text { com algumas } \\
\text { informações }\end{array}$ & $\begin{array}{l}\text { Lista de projetos } \\
\text { com algumas } \\
\text { informações }\end{array}$ \\
\hline Avaliação & $\begin{array}{l}\text { Avaliação de } \\
\text { retorno e } \\
\text { alinhamento, com } \\
\text { critérios táticos e } \\
\text { estratégicos }\end{array}$ & $\begin{array}{l}\text { Avaliação } \\
\text { qualitativa sem } \\
\text { critérios táticos ou } \\
\text { estratégicos pré- } \\
\text { definidos }\end{array}$ & $\begin{array}{l}\text { Avalia conforme } \\
\text { critérios } \\
\text { estratégicos }\end{array}$ & $\begin{array}{l}\text { Avaliação de } \\
\text { retorno e } \\
\text { alinhamento, com } \\
\text { critérios táticos e } \\
\text { estratégicos }\end{array}$ \\
\hline Composição & $\begin{array}{l}\text { Seleção e } \\
\text { priorização dos } \\
\text { projetos, } \\
\text { cancelamentos, } \\
\text { suspensões }\end{array}$ & $\begin{array}{l}\text { Seleção e } \\
\text { priorização, adições } \\
\text { mudanças de } \\
\text { prioridade. } \\
\text { Cancelamentos são } \\
\text { raros }\end{array}$ & $\begin{array}{l}\text { Seleção e } \\
\text { priorização dos } \\
\text { projetos, } \\
\text { cancelamentos, } \\
\text { suspensões }\end{array}$ & $\begin{array}{l}\text { Seleção e } \\
\text { priorização dos } \\
\text { projetos, } \\
\text { cancelamentos, } \\
\text { suspensões }\end{array}$ \\
\hline Administração & $\begin{array}{l}\text { Constante } \\
\text { acompanhamento } \\
\text { em detalhe dos } \\
\text { recursos utilizados, } \\
\text { mas com espaço } \\
\text { para melhorias nos } \\
\text { sistemas utilizados }\end{array}$ & $\begin{array}{l}\text { Utilização dos } \\
\text { recursos não é } \\
\text { acompanhada de } \\
\text { forma eficaz, com } \\
\text { freqüentes } \\
\text { alterações devido às } \\
\text { mudanças } \\
\text { estratégicas e } \\
\text { demandas de cliente }\end{array}$ & $\begin{array}{l}\text { Procura } \\
\text { acompanhar em } \\
\text { detalhe o uso } \\
\text { dos recursos em } \\
\text { cada projeto, } \\
\text { equipes } \\
\text { pequenas }\end{array}$ & $\begin{array}{l}\text { Intenso foco no } \\
\text { acompanhamento } \\
\text { dos recursos, mas } \\
\text { ainda com algumas } \\
\text { deficiências }\end{array}$ \\
\hline Revisão & $\begin{array}{l}\text { Reuniões } \\
\text { freqüentes em } \\
\text { função da } \\
\text { importância do } \\
\text { projeto, revisão } \\
\text { anual do portfólio }\end{array}$ & $\begin{array}{l}\text { Reuniões freqüentes } \\
\text { para revisão dos } \\
\text { projetos e do } \\
\text { portfólio, porém } \\
\text { usam poucos } \\
\text { indicadores }\end{array}$ & $\begin{array}{l}\text { Reuniões } \\
\text { quinzenais com } \\
\text { relatório de } \\
\text { indicadores } \\
\text { sobre todos os } \\
\text { projetos }\end{array}$ & $\begin{array}{l}\text { Revisão anual do } \\
\text { portfólio, pouco } \\
\text { uso de indicadores }\end{array}$ \\
\hline
\end{tabular}

Quadro 15 - Comparação entre os casos e o modelo de Rabechini Júnior, Maximiano e Martins

Ao comparar os processos e práticas de gestão nas empresas verifica-se que a BETA e a WEG apresentam grandes semelhança com esse modelo.

\subsubsection{Modelo de Archer e Ghasemzadeh}

Os casos também foram comparados ao modelo de gestão de portfólio sugerido por Archer e Ghasemzadeh (1999), descrito anteriormente no item 2.2.2.2, que resultou no quadro seguinte: 


\begin{tabular}{|c|c|c|c|c|}
\hline PROCESSO & ALFA & BETA & TIGRE & WEG \\
\hline Propostas & $\begin{array}{l}\text { Pesquisa sistemática do } \\
\text { mercado, intensa coleta } \\
\text { de idéias para novos } \\
\text { produtos e tendências } \\
\text { tecnológicas }\end{array}$ & $\begin{array}{l}\text { Identifica } \\
\text { oportunidades } \\
\text { mas sem um } \\
\text { mecanismo } \\
\text { sistemático }\end{array}$ & $\begin{array}{l}\text { Processo intensivo } \\
\text { de prospecção do } \\
\text { mercado }\end{array}$ & $\begin{array}{l}\text { Processo intensivo e } \\
\text { ainda turbulento de } \\
\text { coleta de idéias, mas } \\
\text { com registro } \\
\text { sistemático }\end{array}$ \\
\hline Pré-avaliação & $\begin{array}{l}\text { Análise de viabilidade, } \\
\text { estimação de parâmetros } \\
\text { para avaliação, } \\
\text { alinhamento estratégico, } \\
\text { identificação de projetos } \\
\text { críticos }\end{array}$ & $\begin{array}{l}\text { Qualitativa, feita } \\
\text { pela diretoria, } \\
\text { viabilidade } \\
\text { técnico-comercial, } \\
\text { identificação de } \\
\text { projetos críticos }\end{array}$ & $\begin{array}{l}\text { Análise de } \\
\text { viabilidade, } \\
\text { estimação de } \\
\text { parâmetros para } \\
\text { avaliação, } \\
\text { alinhamento } \\
\text { estratégico, } \\
\text { identificação de } \\
\text { projetos críticos }\end{array}$ & $\begin{array}{l}\text { Análise de } \\
\text { viabilidade, } \\
\text { estimação de } \\
\text { parâmetros para } \\
\text { avaliação, } \\
\text { alinhamento } \\
\text { estratégico, } \\
\text { identificação de } \\
\text { projetos críticos }\end{array}$ \\
\hline $\begin{array}{l}\text { Análise } \\
\text { individual }\end{array}$ & $\begin{array}{l}\text { Estudo de viabilidade } \\
\text { usando indicadores } \\
\text { financeiros e análise de } \\
\text { risco. Define conjunto } \\
\text { comum de parâmetros } \\
\text { para projetos do mesmo } \\
\text { tipo }\end{array}$ & $\begin{array}{l}\text { Análise } \\
\text { qualitativa de } \\
\text { viabilidade, não } \\
\text { define conjunto } \\
\text { comum de } \\
\text { parâmetros para } \\
\text { comparação entre } \\
\text { os projetos }\end{array}$ & $\begin{array}{l}\text { Estudo de } \\
\text { viabilidade usando } \\
\text { indicadores } \\
\text { financeiros. Define } \\
\text { conjunto comum } \\
\text { de parâmetros para } \\
\text { todos os projetos }\end{array}$ & $\begin{array}{l}\text { Estudo de } \\
\text { viabilidade técnico- } \\
\text { comercial usando } \\
\text { indicares financeiros } \\
\text { e análise qualitativa. } \\
\text { Não define um } \\
\text { conjunto comum de } \\
\text { parâmetros }\end{array}$ \\
\hline Análise sinérgica & $\begin{array}{l}\text { Análise qualitativa para } \\
\text { evitar sobreposições }\end{array}$ & $\begin{array}{l}\text { Análise } \\
\text { qualitativa para } \\
\text { evitar } \\
\text { sobreposições }\end{array}$ & $\begin{array}{l}\text { Análise qualitativa } \\
\text { para evitar } \\
\text { sobreposições }\end{array}$ & $\begin{array}{l}\text { Análise qualitativa } \\
\text { para evitar } \\
\text { sobreposições }\end{array}$ \\
\hline Seleção & $\begin{array}{l}\text { Não utiliza nenhum } \\
\text { modelo ou algoritmo } \\
\text { para calcular o portfólio } \\
\text { ótimo }\end{array}$ & $\begin{array}{l}\text { Não utiliza } \\
\text { nenhum modelo } \\
\text { ou algoritmo para } \\
\text { calcular o } \\
\text { portfólio ótimo }\end{array}$ & $\begin{array}{l}\text { Não utiliza } \\
\text { nenhum modelo ou } \\
\text { algoritmo para } \\
\text { calcular o portfólio } \\
\text { ótimo }\end{array}$ & $\begin{array}{l}\text { Não utiliza nenhum } \\
\text { modelo ou algoritmo } \\
\text { para calcular o } \\
\text { portfólio ótimo }\end{array}$ \\
\hline Ajustes & $\begin{array}{l}\text { Priorização da lista de } \\
\text { projetos }\end{array}$ & $\begin{array}{l}\text { Priorização da } \\
\text { lista de projetos }\end{array}$ & $\begin{array}{l}\text { Priorização da lista } \\
\text { de projetos }\end{array}$ & $\begin{array}{l}\text { Priorização da lista } \\
\text { de projetos }\end{array}$ \\
\hline Desenvolvimento & $\begin{array}{l}\text { Sistema de banco de } \\
\text { dados para } \\
\text { acompanhamento dos } \\
\text { indicadores de todos os } \\
\text { projetos }\end{array}$ & $\begin{array}{l}\text { Coordenadores } \\
\text { fornecem } \\
\text { informações de } \\
\text { acompanhamento, } \\
\text { mas não há um } \\
\text { sistema de banco } \\
\text { de dados único } \\
\end{array}$ & $\begin{array}{l}\text { Possui banco de } \\
\text { dados, acompanha } \\
\text { andamento e } \\
\text { performance de } \\
\text { execução dos } \\
\text { projetos }\end{array}$ & $\begin{array}{l}\text { Acompanhamento } \\
\text { por meio de } \\
\text { sofisticado banco de } \\
\text { dados }\end{array}$ \\
\hline Reavaliação & $\begin{array}{l}\text { Uso de indicadores } \\
\text { globais e por projeto, } \\
\text { elaborados pelo PMO, } \\
\text { exceções podem } \\
\text { disparar revisões no } \\
\text { portfólio }\end{array}$ & $\begin{array}{l}\text { Não define } \\
\text { indicadores de } \\
\text { acompanhamento }\end{array}$ & $\begin{array}{l}\text { Possui indicador } \\
\text { de performance } \\
\text { para cada projeto } \\
\text { individual mas não } \\
\text { para o portfólio }\end{array}$ & $\begin{array}{l}\text { Uso de indicadores } \\
\text { de eficácia e } \\
\text { eficiência }\end{array}$ \\
\hline Finalização & $\begin{array}{l}\text { Lança produtos com } \\
\text { frequiência }\end{array}$ & $\begin{array}{l}\text { Lança produtos } \\
\text { com freqüência }\end{array}$ & $\begin{array}{l}\text { Lança produtos } \\
\text { com freqüência }\end{array}$ & $\begin{array}{l}\text { Lança produtos com } \\
\text { freqüência }\end{array}$ \\
\hline
\end{tabular}

Quadro 16 - Comparação entre os casos e o modelo de Archer e Ghasemzadeh 


\begin{tabular}{|c|c|c|c|c|}
\hline PROPOSIÇÃO & ALFA & BETA & TIGRE & WEG \\
\hline $\begin{array}{l}\text { Antes de iniciar a seleção de projetos, decisões estratégicas a } \\
\text { respeito do foco do portfólio e do orçamento total devem ser } \\
\text { tomadas, num contexto amplo que leva em conta fatores } \\
\text { internos e externos do negócio. }\end{array}$ & $\sqrt{ }$ & & $\sqrt{ }$ & $\sqrt{ }$ \\
\hline $\begin{array}{l}\text { O modelo de gestão de portfólio usado deve ser flexível o } \\
\text { suficiente para que os gestores possam escolher } \\
\text { antecipadamente técnicas ou metodologias com as quais } \\
\text { estejam confortáveis. }\end{array}$ & $\sqrt{ }$ & & $\sqrt{ }$ & $\sqrt{ }$ \\
\hline $\begin{array}{l}\text { Para simplificar o processo de seleção de projetos ele deve ser } \\
\text { organizado em estágios, permitindo aos gestores moverem-se } \\
\text { em um caminho lógico na direção dos projetos com maior } \\
\text { probabilidade de seleção. }\end{array}$ & $\sqrt{ }$ & & $\sqrt{ }$ & \\
\hline $\begin{array}{l}\text { Os usuários não devem ser sobrecarregados com dados } \\
\text { desnecessários, mas devem poder acessar dados relevantes } \\
\text { quando for preciso. }\end{array}$ & & & $\sqrt{ }$ & $\sqrt{ }$ \\
\hline $\begin{array}{l}\text { Medidas comuns devem ser escolhidas, que possam ser } \\
\text { calculadas separadamente para cada projeto. Isso permitirá } \\
\text { uma comparação equânime dos projetos durante o processo de } \\
\text { seleção do portfólio. }\end{array}$ & $\sqrt{ }$ & & $\sqrt{ }$ & \\
\hline $\begin{array}{l}\text { Projetos em andamento que atingirem determinados estágios } \\
\text { devem ser reavaliados ao mesmo tempo em que novos projetos } \\
\text { são considerados para seleção. }\end{array}$ & $\sqrt{ }$ & $\sqrt{ }$ & $\sqrt{ }$ & $\sqrt{ }$ \\
\hline $\begin{array}{l}\text { Uma avaliação inicial baseada em critérios cuidadosamente } \\
\text { definidos deve ser realizada para eliminar alguns projetos antes } \\
\text { mesmo que o processo de seleção do portfólio seja iniciado. }\end{array}$ & $\sqrt{ }$ & & $\sqrt{ }$ & \\
\hline $\begin{array}{l}\text { As interações entre os projetos por meio da dependência direta } \\
\text { ou competição por recursos devem ser consideradas na seleção } \\
\text { do portfólio. }\end{array}$ & $\sqrt{ }$ & & & $\sqrt{ }$ \\
\hline $\begin{array}{l}\text { A seleção do portfólio deve levar em consideração a forma } \\
\text { pela qual os recursos disponíveis serão utilizados ao longo do } \\
\text { tempo. }\end{array}$ & $\sqrt{ }$ & & & $\sqrt{ }$ \\
\hline \multicolumn{5}{|l|}{$\begin{array}{l}\text { Os gestores devem poder alterar a seleção de projetos gerada } \\
\text { por qualquer algoritmo ou modelo, recebendo de volta as } \\
\text { conseqüências de tais mudanças. }\end{array}$} \\
\hline $\begin{array}{l}\text { A seleção de projetos para o portfólio deve ser adaptável a } \\
\text { ambientes de suporte à tomada de decisão em grupo. }\end{array}$ & $\sqrt{ }$ & $\sqrt{ }$ & $\sqrt{ }$ & $\sqrt{ }$ \\
\hline
\end{tabular}

Quadro 17 - Verificação das proposições de Archer e Ghasemzadeh nas empresas

A comparação das atividades executadas em cada empresa com seus processos permitiu identificar que e ALFA e a TIGRE apresentam o maior número de atividades relacionadas às premissas desse modelo. 


\subsubsection{Modelo de Cooper}

Retomando o modelo de gestão de portfólio sugerido por Cooper (1994) e apresentado no item 2.2.2.3, seus processos e premissas foram comparados às práticas de cada empresa, produzindo o quadro resumo seguinte:

\begin{tabular}{|c|c|c|c|c|}
\hline PROCESSO & ALFA & BETA & TIGRE & WEG \\
\hline Geração da idéia & $\begin{array}{l}\text { Forte orientação pela } \\
\text { evolução tecnológica }\end{array}$ & $\begin{array}{l}\text { Forte orientação } \\
\text { pela evolução } \\
\text { tecnológica }\end{array}$ & $\begin{array}{l}\text { Forte orientação } \\
\text { pelo mercado }\end{array}$ & $\begin{array}{l}\text { Forte orientação pelo } \\
\text { mercado }\end{array}$ \\
\hline $\begin{array}{l}\text { Definição do } \\
\text { escopo }\end{array}$ & Plano de negócios & $\begin{array}{l}\text { Detalhamento } \\
\text { técnico-comercial }\end{array}$ & $\begin{array}{l}\text { Plano de } \\
\text { negócios }\end{array}$ & $\begin{array}{l}\text { Detalhamento } \\
\text { técnico-comercial }\end{array}$ \\
\hline $\begin{array}{l}\text { Avaliação do } \\
\text { negócio }\end{array}$ & $\begin{array}{l}\text { Faz avaliação } \\
\text { sistemática de riscos, } \\
\text { maturidade, recursos } \\
\text { disponíveis, retorno e } \\
\text { contribuição } \\
\text { estratégica, com } \\
\text { equipe } \\
\text { interdepartamental }\end{array}$ & $\begin{array}{l}\text { Faz análise } \\
\text { qualitativa de } \\
\text { viabilidade técnica e } \\
\text { comercial, com } \\
\text { representantes de } \\
\text { vários } \\
\text { departamentos }\end{array}$ & $\begin{array}{l}\text { Faz avaliação de } \\
\text { retorno e } \\
\text { contribuição } \\
\text { estratégica, com } \\
\text { participação de } \\
\text { representantes de } \\
\text { várias áreas }\end{array}$ & $\begin{array}{l}\text { Faz avaliação de } \\
\text { riscos, retorno, } \\
\text { contribuição } \\
\text { estratégica, com } \\
\text { forte processo } \\
\text { coletivo, avaliando } \\
\text { também os recursos } \\
\text { disponíveis }\end{array}$ \\
\hline Desenvolvimento & $\begin{array}{l}\text { Possui processo claro } \\
\text { com fases definidas } \\
\text { para cada tipo de } \\
\text { projeto e equipes } \\
\text { dedicadas para } \\
\text { otimizar o uso dos } \\
\text { recursos e aumentar a } \\
\text { eficiência }\end{array}$ & $\begin{array}{l}\text { Agrega diversas } \\
\text { funções para reduzir } \\
\text { tempos e } \\
\text { desenvolver mais } \\
\text { projetos, porém } \\
\text { compartilha uma } \\
\text { mesma equipe entre } \\
\text { todos os projetos }\end{array}$ & $\begin{array}{l}\text { Compartilha uma } \\
\text { mesma equipe } \\
\text { entre todos os } \\
\text { projetos mas } \\
\text { procurar evitar } \\
\text { sobrecarga }\end{array}$ & $\begin{array}{l}\text { As fases do processo } \\
\text { não são claras, mas } \\
\text { possui equipes } \\
\text { dedicadas a cada tipo } \\
\text { de projeto para } \\
\text { otimizar o uso dos } \\
\text { recursos e aumentar } \\
\text { a eficiência }\end{array}$ \\
\hline Teste e validação & $\begin{array}{l}\text { Possui fase específica } \\
\text { para a validação e } \\
\text { finalização }\end{array}$ & $\begin{array}{l}\text { Possui fase } \\
\text { específica para a } \\
\text { validação e } \\
\text { finalização }\end{array}$ & $\begin{array}{l}\text { Possui fase } \\
\text { específica para a } \\
\text { validação e } \\
\text { finalização }\end{array}$ & $\begin{array}{l}\text { Faz validação e } \\
\text { finalização dos } \\
\text { projetos }\end{array}$ \\
\hline $\begin{array}{l}\text { Revisão após } \\
\text { lançamento }\end{array}$ & $\begin{array}{l}\text { Acompanhamento } \\
\text { sistemático de cada } \\
\text { produto baseado em } \\
\text { indicadores de vendas, } \\
\text { qualidade e marketing. } \\
\text { Procura quantificar o } \\
\text { valor criado pelo } \\
\text { portfólio. Procura } \\
\text { gerir o conhecimento } \\
\text { criado. }\end{array}$ & $\begin{array}{l}\text { Acompanhamento } \\
\text { de cada produto } \\
\text { individualmente } \\
\text { através de indicador } \\
\text { de retorno de } \\
\text { investimento, } \\
\text { monitoração de } \\
\text { vendas e qualidade }\end{array}$ & $\begin{array}{l}\text { Forte } \\
\text { acompanhamento } \\
\text { pelo setor de } \\
\text { marketing, } \\
\text { comparação de } \\
\text { desempenho com } \\
\text { os objetivos } \\
\text { planejados }\end{array}$ & $\begin{array}{l}\text { Acompanhamento } \\
\text { sistemático de cada } \\
\text { produto baseado em } \\
\text { indicadores de } \\
\text { vendas, qualidade e } \\
\text { marketing. Procura } \\
\text { disseminar o } \\
\text { conhecimento na } \\
\text { organização. }\end{array}$ \\
\hline
\end{tabular}

Quadro 18 - Comparação entre os casos e o modelo de Cooper

As práticas de gestão, fases e etapas utilizadas na TIGRE são bastante análogas ao modelo de Cooper (1994). Porém, dos três objetivos da gestão de portfólio apresentados por esse modelo (maximização de valor, balanceamento entre os projetos e alinhamento estratégico) apenas o alinhamento estratégico foi observado em todas as empresas. 


\subsubsection{Modelo do PMI}

A comparação entre o modelo do PMI (2006b), com as práticas utilizadas nas empresas, se encontra no quadro resumo seguinte:

\begin{tabular}{|c|c|c|c|c|}
\hline PROCESSO & ALFA & BETA & TIGRE & WEG \\
\hline $\begin{array}{l}\text { Planejamento } \\
\text { estratégico }\end{array}$ & $\begin{array}{l}\text { Define objetivos estratégicos e orçamento } \\
\text { para categorias de projetos, alinhados } \\
\text { com a visão e a missão da empresa }\end{array}$ & $\begin{array}{l}\text { Define visão e missão, mas não declara } \\
\text { objetivos nem orçamento para o } \\
\text { desenvolvimento de novos produtos }\end{array}$ & $\begin{array}{l}\text { Define objetivos estratégicos com } \\
\text { um orçamento único }\end{array}$ & $\begin{array}{l}\text { Visão e missão orientam as diretrizes } \\
\text { estratégicas para cada área, com orçamentos } \\
\text { independentes }\end{array}$ \\
\hline Identificação & $\begin{array}{l}\text { Gerentes listam os projetos com } \\
\text { informações preliminares, alinhando com } \\
\text { os objetivos estratégicos }\end{array}$ & $\begin{array}{l}\text { Diretoria produz lista de projetos (PGD), } \\
\text { porém os critérios não são claros e as } \\
\text { informações não são detalhadas }\end{array}$ & $\begin{array}{l}\text { PD\&E elabora uma lista baseada nos } \\
\text { objetivos estratégicos, com } \\
\text { informações básicas dos projetos }\end{array}$ & $\begin{array}{l}\text { Gerentes elaboram uma lista de projetos } \\
\text { (PWQP) a partir de filtros das comissões, sem } \\
\text { detalhamento }\end{array}$ \\
\hline Categorização & $\begin{array}{l}\text { Compara os projetos e agrupa em } \\
\text { desenvolvimento tecnológico, projetos de } \\
\text { produto grandes, médios ou pequenos }\end{array}$ & $\begin{array}{l}\text { P\&D classifica os projetos em hardware, } \\
\text { software, tecnologia nova ou dominada, } \\
\text { novos produtos ou manutenção e por } \\
\text { linhas de produtos }\end{array}$ & $\begin{array}{l}\text { PD\&E filtra e classifica os projetos } \\
\text { por área de negócio: casa própria, } \\
\text { agricultura ou infra-estrutura }\end{array}$ & $\begin{array}{l}\text { Gerentes classificam os projetos em } \\
\text { aplicação, novo desenvolvimento, adaptações, } \\
\text { novas tecnologias, otimização ou novos } \\
\text { materiais }\end{array}$ \\
\hline Avaliação & $\begin{array}{l}\text { Detalha os projetos, com informações } \\
\text { quantitativas, indicadores financeiros, } \\
\text { análise de risco, maturidade tecnológica } \\
\text { e outras estimativas }\end{array}$ & $\begin{array}{l}\text { Diretoria e P\&D fazem avaliação de } \\
\text { viabilidade técnica. Não usam } \\
\text { mecanismos de pontuação ou avaliação } \\
\text { de indicadores financeiros }\end{array}$ & $\begin{array}{l}\text { PD\&E detalha os orçamento e as } \\
\text { estimativas de retorno, usa gráficos } \\
\text { de bolha de retorno } \mathrm{x} \text { investimento }\end{array}$ & $\begin{array}{l}\text { Comissão de portfólio detalha os projetos, } \\
\text { com informações quantitativas, análises de } \\
\text { risco, recursos disponíveis e opções } \\
\text { tecnológicas }\end{array}$ \\
\hline Seleção & $\begin{array}{l}\text { COMEX seleciona os projetos com base } \\
\text { em retorno e alinhamento estratégico }\end{array}$ & $\begin{array}{l}\text { Diretoria seleciona os projetos com base } \\
\text { em objetivos estratégicos e demandas de } \\
\text { clientes (Masterplan) }\end{array}$ & $\begin{array}{l}\text { Diretoria seleciona os projetos } \\
\text { alinhados e com maior relação } \\
\text { retorno/risco. }\end{array}$ & $\begin{array}{l}\text { Diretoria seleciona os projetos com maior } \\
\text { relação retorno/risco levando em conta o } \\
\text { alinhamento estratégico }\end{array}$ \\
\hline Priorização & $\begin{array}{l}\text { COMEX prioriza a lista de projetos } \\
\text { selecionados }\end{array}$ & $\begin{array}{l}\text { Diretoria prioriza a lista, mas diretor de } \\
\text { P\&D tem autonomia para alterar }\end{array}$ & Diretoria prioriza a lista de projetos & $\begin{array}{l}\text { Comissão de portfólio prioriza e diretoria faz } \\
\text { os ajustes e aprova a lista de projetos }\end{array}$ \\
\hline Balanceamento & $\begin{array}{l}\text { Nas etapas anteriores já se buscou um } \\
\text { equilíbrio entre os tipos de projetos }\end{array}$ & $\begin{array}{l}\text { Busca-se o equilíbrio entre tipos de } \\
\text { projetos, mas os critérios não são claros }\end{array}$ & $\begin{array}{l}\text { Não há intenção explícita de buscar } \\
\text { um equilíbrio }\end{array}$ & $\begin{array}{l}\text { Já se buscou equilibrar os tipos de projetos } \\
\text { nas etapas de avaliação e seleção }\end{array}$ \\
\hline Autorização & $\begin{array}{l}\text { Divulga o planejamento tecnológico entre } \\
\text { as áreas e aloca recursos para os projetos } \\
\text { de acordo com a prioridade. Não há } \\
\text { divulgação de resultados esperados para o } \\
\text { portfólio }\end{array}$ & $\begin{array}{l}\text { Diretor de P\&D aloca recursos de acordo } \\
\text { com a prioridade dos projetos listados no } \\
\text { Masterplan. Não há divulgação de } \\
\text { resultados esperados para o portfólio }\end{array}$ & $\begin{array}{l}\text { Divulga internamente a lista de } \\
\text { projetos. Aloca recursos por } \\
\text { negociação entre líderes de projetos. } \\
\text { Não há divulgação de resultados } \\
\text { esperados para o portfólio }\end{array}$ & $\begin{array}{l}\text { Divulga lista priorizada de projetos para o ano } \\
\text { (PWQP). Aloca recursos por negociação entre } \\
\text { os gerentes das áreas. Não há divulgação de } \\
\text { resultados esperados para o portfólio. }\end{array}$ \\
\hline Revisão & $\begin{array}{l}\text { Juntamente com o acompanhamento dos } \\
\text { projetos ou em mudanças estratégicas }\end{array}$ & $\begin{array}{l}\text { Com o acompanhamento dos projetos ou } \\
\text { por demanda de clientes }\end{array}$ & $\begin{array}{l}\text { Reuniões de acompanhamento dos } \\
\text { projetos e pedidos da diretoria }\end{array}$ & $\begin{array}{l}\text { Reuniões de acompanhamento dos projetos, } \\
\text { ajustes dos gerentes e pedidos da diretoria }\end{array}$ \\
\hline $\begin{array}{l}\text { Mudança } \\
\text { estratégica }\end{array}$ & $\begin{array}{l}\text { Há mecanismos para refletir as mudanças } \\
\text { estratégicas no portfólio de projetos }\end{array}$ & $\begin{array}{l}\text { Há mecanismos para responder } \\
\text { rapidamente às demandas e mudanças } \\
\text { estratégicas }\end{array}$ & $\begin{array}{l}\text { Revisa quinzenalmente o portfólio } \\
\text { para mantê-lo atualizado }\end{array}$ & $\begin{array}{l}\text { Possui mecanismos eficientes para refletir as } \\
\text { mudanças estratégicas no portfólio de projetos }\end{array}$ \\
\hline $\begin{array}{c}\text { Execução e } \\
\text { acompanhamento }\end{array}$ & $\begin{array}{l}\text { Banco de dados único com indicadores } \\
\text { dos projetos e do portfólio }\end{array}$ & $\begin{array}{l}\text { Reuniões periódicas para } \\
\text { acompanhamento e revisão do portfólio }\end{array}$ & $\begin{array}{l}\text { Banco de dados único, com } \\
\text { indicadores de performance e custo }\end{array}$ & $\begin{array}{l}\text { Sofisticado sistema de acompanhamento dos } \\
\text { projetos }\end{array}$ \\
\hline
\end{tabular}


O modelo do PMI é o único modelo teórico, entre os usados nessa pesquisa, que menciona a categorização dos projetos como um processo independente. Dada a aderência das práticas utilizadas pelas empresas a esse processo e a importância dada à classificação dos projetos, considera-se que isso seja uma vantagem desse modelo, pois formaliza a importância da classificação como fase de levantamento de informações sobre os projetos, de forma a poder compará-los explicitamente. Observa-se que nenhuma das empresas possui atividades específicas divididas em processos da mesma forma que no modelo. Diversas atividades são executadas em processos diferentes ou então atividades de vários processos são aglutinadas em um processo único. Isso indica que as empresas ainda não atingiram um nível de maturidade na gestão do portfólio comparável ao exigido pelo modelo do PMI (2006b). 


\section{V - CONSIDERAÇÕES FINAIS}

Por meio de um estudo multicaso realizado na ALFA, BETA, TIGRE e WEG essa pesquisa identificou as práticas de gestão do portfólio de projetos de novos produtos nas multinacionais brasileiras, comparou as práticas utilizadas entre elas, analisou essas práticas sob a ótica dos modelos teóricos e por fim identificou a influência das unidades do exterior no processo de gestão de portfólio da matriz. Procurou-se investigar o entorno do processo de desenvolvimento de produtos, buscando os processos anteriores, usados para decidir por desenvolver ou não um ou mais projetos e também aqueles usados para avaliar as decisões tomadas depois que o produto é lançado.

Todas as empresas pesquisadas realizam a gestão dos projetos de forma conjunta, o que também é conhecido como gestão de múltiplos projetos conforme descrevem Dye e Pennypacker (2000) e Kruglianskas et al. (2006). Também foram encontradas evidências em todos os casos de que a gestão dos projetos tem como escopo principal implementar a estratégia da organização e que o principal critério para seleção e priorização dos projetos é o alinhamento estratégico. Porém, as práticas identificadas nas empresas estão apenas parcialmente alinhadas às atividades indicadas nos modelos teóricos. De acordo com todos os entrevistados, as empresas reconhecem a importância estratégica da gestão do portfólio de projetos de novos produtos e reafirmam que ele é fundamental para melhorar a performance da empresa, em acordo com o que afirmam Roussel, Saad e Erickson (1991).

As empresas possuem iniciativas concretas no sentido de implementar uma gestão eficiente do portfólio de projetos, por meio de um gerenciamento de projetos de forma sistêmica, extrapolando as fronteiras dos departamentos de desenvolvimento e envolvendo diversas áreas da empresa em torno de seu planejamento estratégico, conforme sugere o modelo do PMI (2004). Como o foco da gestão é mais estratégico do que tático, pode-se afirmar que as empresas realmente buscam privilegiar a gestão do portfólio ao invés de apenas uma gestão de múltiplos projetos (DYE; PENNYPACKER, 2000). 
Resgatando a seção 4.5.1, no quadro seguinte estão listadas as práticas identificadas nessas empresas, mostrando a distribuição das práticas por empresa, agrupadas de acordo com os três processos agregados:

\begin{tabular}{|c|c|c|c|c|c|}
\hline & PRÁTICAS IDENTIFICADAS & ALFA & BETA & TIGRE & WEG \\
\hline \multirow{9}{*}{ 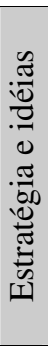 } & 1. Elaborar um plano estratégico formal com objetivos claros & $\bullet$ & $\bullet$ & $\bullet$ & $\bullet$ \\
\hline & 2. Coletar novas idéias de forma abrangente & $\bullet$ & & $\bullet$ & $\bullet$ \\
\hline & 3. Manter um registro formal das novas idéias & $\bullet$ & 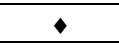 & $\bullet$ & $\bullet$ \\
\hline & 4. Pré-selecionar as idéias usando critérios claros & $\bullet$ & & & $\bullet$ \\
\hline & 5. Designar pessoa ou equipe dedicada à gestão do portfólio & $\bullet$ & & & $\bullet$ \\
\hline & 6. Formar equipe esporadicamente para a gestão do portfólio & 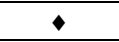 & $\bullet$ & 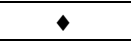 & $\bullet$ \\
\hline & 7. Concentrar as atividades no departamento de P\&D & $\bullet$ & $\bullet$ & $\bullet$ & $\bullet$ \\
\hline & 8. $\quad$ Distribuir as atividades entre departamentos & $\bullet$ & & & $\bullet$ \\
\hline & 9. $\quad$ Definir objetivos estratégicos para novos produtos & $\bullet$ & & $\bullet$ & $\bullet$ \\
\hline \multirow{29}{*}{ 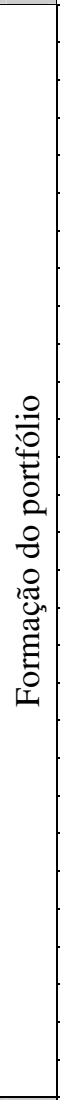 } & 1. Incluir a alta gerência e diretoria nas fases iniciais & & $\bullet$ & 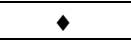 & \\
\hline & 2. Elaborar um plano de negócios para cada projeto & $\bullet$ & & $\bullet$ & 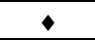 \\
\hline & 3. $\quad$ Filtrar as informações para evitar sobrecarga & $\bullet$ & & $\bullet$ & $\bullet$ \\
\hline & 4. Categorizar os projetos semelhantes & $\bullet$ & 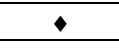 & $\bullet$ & $\bullet$ \\
\hline & 5. Definir critérios claros para avaliar os projetos & $\bullet$ & & $\bullet$ & \\
\hline & 6. Definir um orçamento único para todos os projetos & & 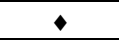 & + & \\
\hline & 7. Definir um orçamento por categorias de projetos & $\bullet$ & & & + \\
\hline & 8. Considerar a capacidade atual de desenvolvimento & $\bullet$ & & & + \\
\hline & 9. Considerar os ativos tecnológicos atuais da empresa & $\bullet$ & & & $\bullet$ \\
\hline & 10. Planejar os recursos necessários & $\bullet$ & & - & $\bullet$ \\
\hline & 11. Uniformizar os critérios de avaliação dos projetos & 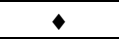 & & $\bullet$ & \\
\hline & 12. Autorizar o início de projetos sem análise do portfólio & & 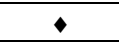 & & $\bullet$ \\
\hline & 13. Envolver diversas áreas na seleção dos projetos & $\bullet$ & $\bullet$ & $\bullet$ & $\bullet$ \\
\hline & 14. Avaliar os projetos usando a experiência dos gestores & $\bullet$ & $\bullet$ & $\bullet$ & $\bullet$ \\
\hline & 15. Avaliar os projetos usando índices financeiros & $\bullet$ & & $\bullet$ & $\bullet$ \\
\hline & 16. Avaliar os projetos usando ferramentas qualitativas & $\bullet$ & & + & \\
\hline & 17. Utilizar gráficos na avaliação dos projetos & + & & + & \\
\hline & 18. Avaliar as sinergias entre os projetos & $\bullet$ & 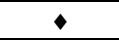 & & 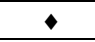 \\
\hline & 19. Avaliar o risco do projeto & 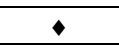 & $\bullet$ & 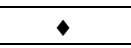 & 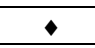 \\
\hline & 20. Avaliar o risco do portfólio & + & & & \\
\hline & 21. Avaliar o alinhamento estratégico & $\bullet$ & $\bullet$ & $\bullet$ & $\bullet$ \\
\hline & 22. Usar histórico dos projetos anteriores & $\bullet$ & & $\bullet$ & \\
\hline & 23. Dividir o processo decisório em fases & $\bullet$ & $\bullet$ & $\bullet$ & 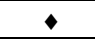 \\
\hline & 24. Reavaliar periodicamente o andamento dos projetos & $\bullet$ & $\bullet$ & 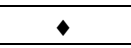 & 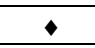 \\
\hline & 25. Selecionar os projetos por retorno financeiro & $\bullet$ & + & $\bullet$ & + \\
\hline & 26. Selecionar os projetos por indicação de patrocinadores & $\bullet$ & 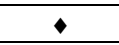 & $\bullet$ & 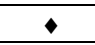 \\
\hline & 27. Selecionar os projetos por alinhamento estratégico & $\bullet$ & $\bullet$ & + & $\bullet$ \\
\hline & 28. Buscar o equilíbrio entre diferentes categorias de projetos & $\bullet$ & $\bullet$ & & 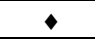 \\
\hline & 29. Alocar recursos por prioridade & 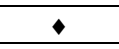 & $\bullet$ & $\bullet$ & $\bullet$ \\
\hline \multirow{12}{*}{ 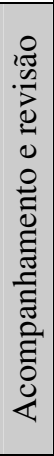 } & 1. Acompanhar os projetos com relação ao uso dos recursos & 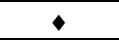 & & + & + \\
\hline & 2. $\quad$ Fornecer informações periódicas sobre cada projeto & 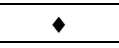 & $\bullet$ & 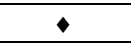 & + \\
\hline & 3. Reavaliar periodicamente o portfólio & $\bullet$ & $\bullet$ & 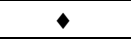 & 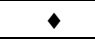 \\
\hline & 4. Reavaliar o portfólio em eventos de mudança estratégica & 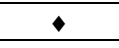 & + & 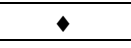 & $\bullet$ \\
\hline & 5. Comparar projetos em andamento com projetos novos & $\bullet$ & & & $\bullet$ \\
\hline & 6. Cancelar ou adiar projetos por mudanças estratégicas & $\bullet$ & $\bullet$ & 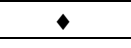 & $\bullet$ \\
\hline & 7. Mudar prioridade de projetos & 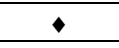 & $\bullet$ & 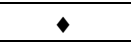 & $\bullet$ \\
\hline & 8. Gerenciar o estresse das equipes & 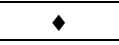 & & & $\bullet$ \\
\hline & 9. Utilizar informações do portfólio no planejamento de RH & + & & & 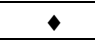 \\
\hline & 10. Auditar os projetos finalizados & 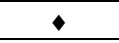 & & + & + \\
\hline & 11. Gerir os novos conhecimentos criados pelos projetos & $\bullet$ & & & $\bullet$ \\
\hline & 12. Avaliar o valor criado pelo portfólio & + & & & \\
\hline
\end{tabular}

Quadro 20 - Resumo das práticas gerenciais identificadas nas empresas

Legenda: $\bullet=$ fraca $\bullet \bullet=$ forte 
As empresas pesquisadas não dividem seu processo de gestão do portfólio de projetos em tantos processos se comparado como os modelos existentes na literatura. A BETA apresenta um processo bastante próximo ao modelo de Rabechini Júnior, Maximiano e Martins (2005), que agrega as atividades em um menor número de fases. A TIGRE e a WEG estão próximas ao modelo de Cooper (1994). A ALFA é a empresa que apresenta o maior número de processos e práticas, se aproximando do modelo de Archer e Ghasemzadeh (1999). O que se observa pelos casos selecionados é que muitos processos descritos nos modelos mais detalhados são executados simultaneamente ou em processo diferentes. Nenhuma das empresas implementa um processo de gestão do portfólio da forma sistemática e completa como o modelo descrito pelo PMI (2006b). Pode-se afirmar, pela relação entre as práticas identificadas nessas empresas e os modelos de referência, que as empresas se encontram em estágios intermediários de maturidade, sendo classificadas, segundo o modelo de maturidade na gestão de projetos de McGrath (1996), nos seguintes estágios:

BETA

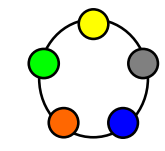

TIGRE

WEG

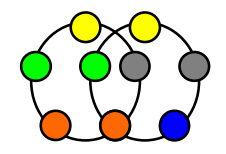

ALFA

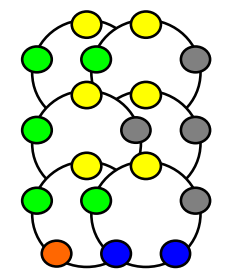

Estágio 2: excelência na execução de projetos isolados, por meio do alinhamento entre as funções, desde a concepção até comercialização do produto. Foco na intensa troca de informações, mas pouca ênfase no compartilhamento de conhecimentos. Paradigma da qualidade.

Estágio 3: excelência em múltiplos projetos, por meio da eficiência na seleção e execução de projetos, alinhamento entre processos e uso de plataformas. Grande ênfase na troca de conhecimentos. Paradigma da flexibilidade.

Estágio 4: excelência em desenvolvimento colaborativo pelo intenso relacionamento entre os processos das funções internas e externas à organização. Intensa criação e conversão de conhecimento, rompendo a fronteira entre a organização e a sociedade. Paradigma da inovação e gestão do conhecimento.

\section{Quadro 21 - Maturidade em gestão de projetos das empresas}

As multinacionais brasileiras gerenciam seus portfólios de projetos de novos produtos de forma muito heterogênea. Cada uma das empresas se encontra em um nível de maturidade diferente com relação à gestão do portfólio. A BETA ainda não possui um processo formal para avaliação, seleção e priorização dos projetos. Apesar de ter ficado evidente que a WEG emprega um esforço considerável para entender suas demandas e buscar idéias de novos produtos que produzam projetos com alto valor agregado, também não há um 
processo formalizado, com fases bem definidas, para a gestão do portfólio. No caso da TIGRE, apesar de haver um processo claro e formal, a empresa lida com uma variação pequena de tecnologias, se comparada às outras empresas, o que facilita a gestão de diversos projetos simultâneos, pois há pouca variação entre eles. A ALFA apresenta o processo mais complexo e formalizado dentre as empresas estudadas. Essa comparação indica que não há relação aparente entre o tamanho da empresa e sua maturidade na gestão do portfólio de projetos.

No caso das empresas com P\&D no exterior (ALFA, BETA e WEG), todos os projetos são discutidos como parte de um planejamento conjunto para atingir objetivos comuns, com exceção da BETA, cujo P\&D nos EUA atua de forma independente. Além disso, o processo de gestão é contínuo, sendo renovado por meio do acompanhamento dos projetos e das revisões no portfólio, comunicando e implementando as decisões estratégicas tomadas em função do ambiente de negócios, como sugerem Kruglianskas et al. (2006). A diversidade de processos, pontos de vista e práticas encontradas em cada uma das empresas confirma que não há uma solução mágica ou modelo único para a gestão do portfólio de projetos, como previnem Cooper et al. (1997).

As unidades estrangeiras participam do processo de gestão do portfólio por meio da identificação das necessidades dos seus mercados locais e da complementação de competências técnicas não disponíveis ou escassas na matriz. Ocorre maior envolvimento das unidades do exterior na fase de planejamento estratégico, quando cada unidade apresenta suas necessidades para atender aos objetivos propostos pela matriz. Outra característica observada é que a influência das unidades estrangeiras na gestão do portfólio da matriz é tanto maior quanto maior for o comprometimento da empresa com o mercado externo. Isso pode ser observado no caso da WEG e da ALFA, pois suas unidades de P\&D no exterior participam ativamente na identificação de oportunidades e na seleção de novos projetos. Nessa mesma perspectiva, as unidades da TIGRE contribuem apenas com indicações de modificações nos produtos já fabricados pela matriz brasileira, apenas para ajustar algumas características para os mercados locais. No caso da BETA, o P\&D externo tem autonomia para propor e desenvolver projetos que não estejam relacionados aos projetos da matriz brasileira. Essa subsidiária até mesmo comercializa produtos próprios, tais como alguns circuitos integrados que são desenvolvidos de forma independente do P\&D no Brasil.

A complementação das competências técnicas foi constatada nos casos da ALFA e da WEG. Em ambas as empresas, algumas unidades do exterior desenvolvem produtos que não são desenvolvidos no Brasil, como no caso da unidade portuguesa da WEG, que desenvolve e 
fabrica motores à prova de explosão ${ }^{1}$, uma tecnologia não disponível na matriz brasileira. No caso da ALFA as unidades do exterior desenvolvem os mesmos tipos de projetos da matriz brasileira, que centraliza todas as tecnologias utilizadas pelas empresas do grupo.

Após identificar inúmeras práticas por meio do estudo multicaso e concluir que a grande maioria encontra respaldo nos modelos teóricos, é possível questionar também se as empresas multinacionais brasileiras não estariam apenas "copiando" as melhores práticas já utilizadas por outras organizações. Nesse contexto, Hamel (2007) afirma que o que realmente estimula o sucesso de longo prazo de uma empresa não é a excelência operacional ou novos modelos de negócios, mas a inovação em gestão: novas maneiras de reunir talentos, distribuir recursos e formular estratégias. Falta à maioria das empresas um processo disciplinado de inovação em gestão. Esse autor ainda afirma ainda que as empresas precisam, mais do que nunca, de ousadia na inovação em gestão. O modelo atual, centrado em controle e eficiência, não é mais suficiente em um mundo em que a adaptabilidade e a criatividade impulsionam o sucesso empresarial. As empresas precisam se libertar dos grilhões dos dogmas de gestão do passado. Os vencedores de amanhã serão as empresas que começarem hoje a inventar o futuro da administração. O autor aponta afirma que as crenças de gestão remanescentes de época passadas têm efeitos prejudiciais nas empresas de hoje.

O processo disciplinado de inovação mencionado por Hamel (2007) encontra respaldo na gestão do portfólio de projetos de novos produtos. O exercício de implementação dos processos e atividades descritos nos modelos teóricos pode beneficiar as empresas por meio da melhoria na eficácia do desenvolvimento de produtos, pensamento alinhado com a segunda onda do gerenciamento de projetos descrita por Rabechini Júnior e Carvalho (2005), onde o foco da empresa deve ser desenvolver os projetos certos, e não apenas melhorar a eficiência. Nesse aspecto, as multinacionais brasileiras pesquisadas têm obtido resultados importantes e eventualmente poderiam melhorar ainda mais caso aperfeiçoassem seus processos de gestão do portfólio, seja pelo uso de modelos teóricos como o de Rabechini Júnior, Maximiano e Martins (2005), Archer e Ghasemzadeh (1999), Cooper (1994) ou do PMI (2006b), seja pela criação de novas práticas mais adequadas à realidade das multinacionais brasileiras.

O lendário empreendedor Henry Ford, que inaugurou a primeira linha de produção de automóveis, há mais de 100 anos, não via nenhuma necessidade de dar autonomia a seus empregados. "Por que toda vez que contrato um par de braços um cérebro tem de vir junto?", reclamava. Muitas décadas depois, o fundador da Sony, Akio Morita, viu-se às voltas com um

\footnotetext{
${ }^{1}$ Motores especiais para aplicações em ambientes com atmosferas explosivas geralmente encontradas em indústrias químicas, petroquímicas, plataformas e refinarias de petróleo.
} 
desafio inverso: "Posso obrigar um operário a chegar na fábrica às 7 horas para trabalhar, mas não posso forçá-lo a ter uma boa idéia”, dizia ele, em uma época em que neurônios começaram a se tornar mais importantes do que músculos. As duas frases sintetizam as transformações radicais vividas pelas empresas no século 20: do modelo fordista de produção massificada para o admirável mundo novo da economia do conhecimento (CRUZ, 2007).

Hamel (2007) afirma que a administração das empresas continua em uma espécie de idade da pedra. As práticas de gestão continuam quase exatamente como nos velhos tempos do Ford $\mathrm{T}$, quando a linha de montagem era a maior novidade no horizonte. $\mathrm{O}$ autor questiona a capacidade da administração clássica de responder aos desafios do novo ambiente de negócios, global, hiper-competitivo e organizado em redes. A única maneira de colocar as empresas burocráticas e autoritárias herdadas da era industrial no rumo da inovação é por meio de uma revolução completa nos pilares da gestão. Os fundamentos da gestão clássica visavam assegurar controle e eficiência na produção manufatureira e basicamente garantir empregados obedientes às ordens vindas dos administradores, num cenário de relativa estabilidade. Porém, seria hora de virar a página e deixar os velhos dogmas para trás em vez de continuar ditando regras pelos corredores corporativos (CRUZ, 2007). Seria hora das empresas brasileiras inventarem novas práticas e revolucionarem sua gestão.

Hamel (2007) argumenta ainda que as empresas estão obcecadas em copiar as chamadas "melhores práticas" ao invés de quererem inventar as "próximas práticas". O autor alega que a administração se tornou prisioneira de seus próprios dogmas, da busca de eficiência cada vez maior da máquina, para entregar mais e mais resultados no curto prazo. Os executivos já não têm tempo para pensar diferente e preparar a empresa para o futuro. Outra dificuldade é que mexer na administração implica em redistribuição de poder, assunto normalmente indigesto para a maioria dos executivos.

Nessa mesma ótica, as organizações que desenvolvem produtos podem se beneficiar da experimentação de novas práticas na gestão do seu portfólio de projetos. Não se trata, contudo, de copiar as práticas de outras empresas. Trata-se sim, de aprender com elas, criando sua própria fórmula de gestão, combinando o aprendizado cristalizado na experiência de outras empresas com o próprio aprendizado, necessidades e experiências. A gestão do portfólio de projetos de novos produtos é uma importante ferramenta para que a empresa faça a gestão da inovação. As práticas apresentadas nessa pesquisa constituem uma referência para iniciar e fomentar esse processo de auto-aprendizado. Por meio da experiência das empresas pesquisadas é possível planejar e experimentar ações que melhorem ou até mesmo revolucionem a gestão de projetos de novos produtos, especialmente no contexto de um 
portfólio com inúmeros projetos sendo avaliados, iniciados, cancelados e finalizados simultaneamente. Seguindo a proposta de Hamel (2007), espera-se que essa pesquisa inspire maiores e mais profundas investigações, abrangendo outras empresas e outros setores da economia, contribuindo para que a indústria nacional seja cada vez mais inovadora e vencedora.

\subsection{LIMITAÇÕES DA PESQUISA}

As conclusões dessa pesquisa não podem ser generalizadas, ainda que algumas delas possam ser estendidas para outras empresas multinacionais brasileiras. Outra restrição diz respeito ao método de pesquisa empregado, que apresenta limitações intrínsecas para capturar a realidade pesquisada. Além disso, as empresas selecionadas desenvolvem produtos similares (equipamentos eletro-eletrônicos). Pesquisas futuras envolvendo empresas de outros segmentos, como software, por exemplo, também podem capturar novas informações sobre o tema.

Uma das dificuldades encontradas na elaboração da pesquisa foi a relutância de algumas empresas em divulgar informações sobre suas práticas de gestão, tais como proporção dos investimentos nas fases do desenvolvimento de um novo produto, alguns objetivos estratégicos ou mesmo valores de investimento em P\&D. Em alguns casos, informações consideradas estratégicas foram suprimidas pelos revisores. Outra limitação pode ser encontrada no fato de que as entrevistas contêm opiniões pessoais dos entrevistados que podem não corresponder totalmente à realidade da empresa.

Não foi objetivo investigar ou listar os critérios utilizados pelas empresas para identificar novas oportunidades de negócio, avaliar, selecionar ou comparar os projetos, o que pode ser alvo de pesquisa futura. $\mathrm{O}$ objetivo também não foi identificar as práticas da gestão operacional dos projetos, mantendo o foco nos aspectos estratégicos da gestão do portfólio de novos produtos. Futuras pesquisas podem incluir questionamentos sobre como empresas do porte das pesquisadas podem desenvolver dezenas de projetos simultâneos sem ter um controle preciso dos custos, do andamento e da performance de execução dos seus projetos? Do ponto de vista dos modelos teóricos de gestão do portfólio, como essas empresas conseguem obter resultados tão positivos, se implementam apenas parte dos processos e atividades sugeridas pelos modelos? Qual o valor agregado pela gestão do portfólio nas empresas e como elas poderiam aperfeiçoar ainda mais seu processo de gestão? 
Para estudos futuros buscar-se-á apresentar possíveis melhorias a serem implementadas nas empresas. Uma questão que surgiu durante a pesquisa está relacionada aos ganhos reais que a empresa obtém ao implementar uma gestão de portfólio baseada nos modelos teóricos, especialmente no modelo do PMI (2006b). A implementação de um modelo de gestão de portfólio, com todos os seus processos e atividades, traz benefícios mensuráveis para a empresa? Outra questão que pode ser aprofundada em futuras pesquisas é com relação à efetividade dos mecanismos de avaliação, seleção e priorização dos projetos. Como as empresas conseguem medir a eficiência do seu processo? Que práticas deveriam ser abolidas e que novas práticas poderiam adicionar valor? 


\section{VI - REFERÊNCIAS ${ }^{1}$}

ABIMAQ anuncia lucro recorde da WEG. Disponível em: <http://www.abimaq.com.br>. Acesso em: 5 mar. 2007.

ALMEIDA, M. S. Tecnologia de informação e criatividade no desenvolvimento de produtos: um estudo de caso em grandes organizações. 2004. 220 f. Tese (Doutorado em Engenharia de Avaliação e de Inovação Tecnológica.) - Departamento de Engenharia de Produção e Sistemas, Universidade Federal de Santa Catarina, Florianópolis, 2004.

ALTMANN, R. M. As Multinacionais Brasileiras com Plantas Industriais no Exterior: Configuração das Operações Internacionais. 2005. 162 f. Dissertação (Mestrado em Engenharia) - Escola Politécnica, Universidade de São Paulo, São Paulo, 2005.

ANTONI, M.; WITELL, L. M.; DAHLGAARD, J. J. Inter project improvement in product development, International Journal of Quality \& Reliability Management, v. 22, n. 9, p. 876-893, 2005.

ARCHER, N. P.; GHASEMZADEH, F. An integrated framework for project portfolio selection. International Journal of Project Management, London, v. 17, n. 4, p. 207-216, 1999.

ARRUDA, C. A.; GOULART, L.; BRASIL, H. V. Estratégias de Internacionalização: Competitividade e Incrementalismo. In: ENANPAD XVIII, 1994, Curitiba. Anais... Curitiba: ANPAD, 1994.

BLAU, G. E.; PEKNY, J. F.; VARMA, V. A.; BUNCH, P. R. Managing a Portfolio of Interdependent New Product Candidates in the Pharmaceutical Industry. The Journal of Product Innovation Management, New York, v. 21, n. 4, p. 227-245, 2004.

BOYD, H. W.; WESTFALL, R. Pesquisa mercadológica: textos e casos. $7^{\text {a }}$ Ed. Rio de Janeiro: F.G.V., 1987. 803 p.

CARVALHO, M. M.; RABECHINI JÚNIOR, R.; PESSÔA, M.; LAURINDO, F. J. B. Equivalência e completeza: análise de dois modelos de maturidade em gestão de projetos. Revista de Administração da Universidade de São Paulo, São Paulo, v. 40, n.3, p. 289300, jul/set 2005.

\footnotetext{
${ }^{1}$ Referências e citações em acordo com a ABNT, NBR 6023.
} 
CLARK, K. B.; WHEELWRIGHT, S. C. Managing New Product and Process Development. $1^{\text {st }}$ Edition. New York: The Free Press, 1992. 896 p.

CLARK, K. B.; FUJIMOTO, T. Product development performance: strategy, organization and management in the world auto industry. Boston: Harvard Business School Press, 1991. $350 \mathrm{p}$.

COOPER, R. G. Third-Generation New Product Processes. Journal of Product Innovation Management, New York, v. 11, p.3-14, 1994.

COOPER, R. G.; EDGETT, S. J. Overcoming the crunch in resources for new product development: poor NPD performance can most often be traced to a significant shortage of people and time. Here's what you can do about that. (Managers at Work). ResearchTechnology Management, v. 46, n. 3, p. 48-59, May-June 2003.

COOPER, R. G.; EDGETT, S. T.; KLEINSCHMIDT, E. J. Portfolio Management for new products. Hamilton: McMaster University Press, 1997. 131 p.

New Product portfolio Management: Practices and Performance. Journal of Product Innovation Management, New York, v. 16, p. 333-351, 1999.

Portfolio management for new product development: results of an industry practices study. R\&D Management, Oxford, v. 31, n. 4, p. 361-380, 2001.

Benchmarking Best NPD Practices - I. Research-Technology Management, Arlington, v. 47, n. 1, p. 31-43, Jan-Feb 2004a.

Benchmarking Best NPD Practices - II. Research-Technology Management, Arlington, v. 47, n. 3, p. 50-59, May-Jun 2004b.

Benchmarking Best NPD Practices - III. Research-Technology Management, Arlington, v. 47, n. 6, p. 43-55, Nov-Dec 2004c.

COSTA, P. R. A cooperação tecnológica nas multinacionais brasileiras: um estudo multicaso. 2007. 236 f. Dissertação (Mestrado) - Faculdade de Economia., Administração e Contabilidade de Ribeirão Preto, Universidade de São Paulo, Ribeirão Preto, 2007. 
CRUZ, S. S. As empresas estão na idade da pedra. Disponível em: $<$ http://portalexame.abril.com.br/revista/exame/edicoes/0905/gestaoepessoas/m0142221.html >. Acesso em: 12 dez. 2007.

CSILlAG, J. M. O Gerenciamento de Projetos Segundo a Teoria das Restrições. Escola de Administração de Empresas de São Paulo Fundação Getúlio Vargas - NPP Núcleo de Pesquisas e Publicações, Relatório de Pesquisa n. 2, São Paulo, 2001. Thousands: Sage Publications, 1994.

DE MAIO, A.; VERGANTI, R.; CORSO, M. A multi-project management framework for new product development, European Journal of Operational Research, v. 78, p. 178-191, 1994.

DREJER, A.; GUDMUNDSSON, A. Exploring the concept of multiple product development via an action research project, Integrated Manufacturing Systems, v. 14, n. 3, p. 208-220, 2003.

DYE, L. D.; PENNYPACKER, J. S. Multiple Projects: Two Sides of the Same Coin? In: PROJECT MANAGEMENT INSTITUTE ANNUAL SEMINARS \& SYMPOSIUM, 2000, Houston, Texas, USA. Proceedings...Houston: Project Management Institute, 2000.

ELONEN, S.; ARTTO, K. A. Problems in managing internal development projects in multiproject environments, International Journal of Project Management, London, v. 21, p. 395-402, 2003.

EVERS, J. H. Multi-project support issues: cycle time and schedule effects when people support multiple concurrent projects. In: ENGINEERING MANAGEMENT SOCIETY, 2000, Albuquerque, New Mexico, USA. Proceedings of the 2000 IEEE Engineering Management Society. Piscataway: IEEE, 2000. p. 19-24.

FACHIN, O. Fundamentos de Metodologia. São Paulo: Saraiva, 2001. 200 p.

FDC - FUNDAÇÃO DOM CABRAL. WEG: Adaptando o Capitalismo familiar ao mercado global. Casos FDC - CF 0204. Nova Lima: Centro Alfa, Campus Aloysio Faria. 2003. 21 p.

FINEP, Prêmio FINEP de Inovação Tecnológica, 2007. Disponível em: <http://www.finep.gov.br/premio/historico.htm>. Acesso em: 9 abr. 2007.

FINEP, Tigre recebe recursos para investimento em P\&D. Disponível em $<$ http://www.finep.gov.br/imprensa/noticia.asp?cod_noticia=1169>. Acesso em: 12 jan. 2008. 
FRICKE, S. E.; SHENBAR, A. J. Managing Multiple Engineering Projects in a Manufacturing Support Environment. IEEE Transaction on Engineering Management, Bloomington, v. 47, n. 2, p. 258-268, May 2000.

GIL, A. C. Métodos e Técnicas de Pesquisa Social. 4ª ed. São Paulo: Atlas, 2002. 221 p.

GOULART, L. Dimensões da Internacionalização. Caderno de Idéias, Nova Lima: Fundação Dom Cabral, p. 20, 2004.

HAMEL, G. O futuro da administração. São Paulo: Editora Campus, 2007. 272 p.

HENDRIKS, M. H. A.; VOETEN, B.; KROEP, L. Human resource allocation in a multiproject $\mathrm{R} \& \mathrm{D}$ environment - Resource capacity allocation and project portfolio planning in practice. International Journal of Project Management, London, v. 17, n. 3, p. 181-188, 1999.

IEDI, Instituto de Estudos para o Desenvolvimento Industrial. Carta IEDI $n^{\circ}$. 125: O Brasil Precisa Investir Para Remover os Gargalos da Produção. Disponível em: $<$ http://www.iedi.org.br/cgi/cgilua.exe/sys/start.htm?infoid=723\&sid=20>. Acesso em: 5 mar. 2007.

INNOVATION in emerging markets: Strategies for achieving commercial success. Produced by DELOITTE TOUCHE TOMAHTSU Bosnia \& Herzegovina (A Manufacturing industry group report). Disponível em:<http://www.deloitte.com/dtt/research $>$. Acesso em: $10 \mathrm{fev}$. 2007.

KANNEBLEY JÚNIOR, S.; PORTO, G. S.; PAZELLO, E. T. Inovação na indústria Brasileira: uma Análise Exploratória a Partir da PINTEC. Revista Brasileira de Inovação, Rio de Janeiro, v. 3, n.1, 2004. p. 87 a 128.

KERZNER, H. Applied Project management best practices on implementation. New York: John Wiley \& Sons, 2000. 544 p.

KRUGLIANSKAS, I.; SIVIÉRI, O. A.; PAVAN, O. M.; LOURENÇÃO, P. T. M. Avaliação e priorização de projetos de inovação tecnológica. In: RABECHINI JÚNIOR, R.; CARVALHO, M. M. (Organizadores). Gerenciamento de projetos na prática: casos brasileiros. São Paulo: Editora Atlas, 2006. Capítulo 7, p. 96-122. 
LINTON, J. D.; WALSH, S. T.; MORABITO, J. Analysis, ranking and selection of R\&D projects in a portfolio. R\&D Management, Oxford, v. 32, n. 2, p. 139-148, 2002.

MARTINO, J. Technological forecasting for decision making. $3^{\text {rd }}$ ed. New York: Mc GrawHill Inc, 1993. 462 p.

MARTINS, G. A. Estudo de caso: uma estratégia de pesquisa. São Paulo: Editora Atlas, 2006. 102 p.

MARTINSUO, M.; LEHTONEN, P. Role of single-project management in achieving portfolio management efficiency, International Journal of Project Management, London, v. 25, n. 1 , p. 56-65, Janeiro de 2006.

MCGRATH, M.E. Setting the PACE in Product Development: A Guide to Product and Cycle-time Excellence. rev. ed. Boston: Butterworth-Heinemann, 1996. 240 p.

NONAKA, I.; TAKEUCHI, H. The Knowledge-Creating Company: How Japanese Companies Create the Dynamics of Innovation. Oxford: Oxford University, 1995. 304 p.

NUCHERA, A. H.; SERRANO, G. L.; MOROTE, J. P. La gestión de la innovación y la tecnología en las organizaciones. Madrid: Ediciones Pirámide, 2002. 560 p.

OECD - ORGANIZATION FOR ECONOMIC CO-OPERATION AND DEVELOPMENT. Oslo Manual: Guidelines for Collecting and Interpreting Innovation Data. $3^{\text {rd }}$ Edition. Paris: OECD Publications, 2005. 163 p.

PATAH, L. A.; CARVALHO, M. M. O PMO, Project Management Office, e seu alinhamento estratégico. In: RABECHINI JÚNIOR, R.; CARVALHO, M. M. (Organizadores). Gerenciamento de projetos na prática: casos brasileiros. São Paulo: Editora Atlas, 2006. Cap. 10, p. 156-171.

POPPER, K. R. O realismo e o objetivo da ciência. Lisboa: Publicações Dom Quixote, 1987. $418 \mathrm{p}$.

POSSAMAI, F. A influência da cultura da organização na aprendizagem de executivos: o caso da TIGRE. 2005. 142 p. Teste (Doutorado). Centro Tecnológico, Universidade Federal de Santa Catarina, Florianópolis, 2005. 
PRAHALAD, C. K.; HAMEL, G. The core competence of the corporation. Harvard Business Review, Boston, p. 79-91, May/Jun 1990.

PMI - PROJECT MANAGEMENT INSTITUTE. A Guide to the Project Management Body of Knowledge (PMBOK ${ }^{\circledR}$ Guide). $3^{\text {rd }}$ Edition. Newtown Square: Project Management Institute, 2004. 402 p.

The Standard for Program Management. Newtown Square: Project Management Institute, 2006a. 123 p.

The Standard for Portfolio Management. Newtown Square: Project Management Institute, 2006b. 91 p.

RABECHINI JÚNIOR, R.; CARVALHO, M. M. Construindo Competências para Gerenciar Projetos: teoria e casos. São Paulo: Editora Atlas, 2005. 320 p.

. (Organizadores). Gerenciamento de projetos na prática: Casos Brasileiros. São Paulo. Editora Atlas, 2006. 212 p.

RABECHINI JÚNIOR, R.; MAXIMIANO, A. C. A.; MARTINS, V. A. A adoção do gerenciamento de portfólio como uma alternativa gerencial: o caso de uma empresa prestadora de serviço de interconexão eletrônica, Revista Produção, São Paulo, v. 15, n. 3, Set/Dez 2005. p. 416-433.

REIS, D. R. Gestão da Inovação Tecnológica. São Paulo: Manole, 2004. 170 p.

REPENNING, N. P. Understanding fire fighting in new product development. The Journal of Product Innovation Management, New York, v. 18. n. 5, p. 285-300, 2001.

RICHARDSON, R. J. Pesquisa Social: Métodos e Técnicas. São Paulo: Atlas, 1999. 334 p.

ROUSSEL, A. P.; SAAD, K. N.; ERICKSON, T. J. Third Generation R\&D: Managing to Link to Corporate Strategy. Boston: Harvard Business School Press, 1991. 224 p.

ROZENFELD, H. et al. Gestão de Desenvolvimento de Produtos - Uma referência para a melhoria do processo. São Paulo: Saraiva, 2005. 542 p. 
SBRAGIA, R.; KRUGLIANSKAS, I.; CAMARGOS, S. P. Inovação Tecnológica e Desempenho Empresarial no Novo Contexto Brasileiro: uma análise evolutiva no período de 1993 a 1995. Revista de Administração da USP - RAUSP, São Paulo, v. 33, n. 2, p. 21-28, abr./jun. 1998.

SELLTIZ, et al. Métodos de Pesquisa nas Relações Sociais. v. 2. São Paulo: EPU, 1987. $133 \mathrm{p}$.

SILVA, M. A. Estratégias recentes de crescimento na indústria de equipamentos elétricos do sul do Brasil. GEOGRAFIA - Revista do Departamento de Geociências, Londrina, v. 14, n. 1, p. 155-130, jan./jun. 2005.

SLACK, N.; CHAMBERS, S.; JOHNSTON, R. Administração da Produção. $2^{\text {a }}$ Edição. São Paulo: Editora Atlas, 2002. 745 p.

TIGRE, Inovando para construir melhor, 2008. Disponível em <http://www.tigre.com.br>. Acesso em: 10 jan. 2008.

TRIVIÑOS, A. N. S. Introdução à Pesquisa em Ciências Sociais: a Pesquisa Qualitativa em Educação. São Paulo: Atlas, 1987. 175 p.

UTTERBACK, J. M. Dominando a dinâmica da inovação. Tradução Luiz Liske. Rio de Janeiro: Qualitymark, 1996. 264 p.

VIEIRA, C. R. B., ZILBOVICIUS, M. Empresas Brasileiras com Plantas Industriais no Exterior. In: V Workshop em Internacionalização de Empresas, 2005. Rio de Janeiro. Disponível em: <http://www.coppead.ufrj.br/workshop/docs/artigo_vieira_zilbovicius.pdf>. Acesso em: 20 out. 2007.

WEG, Jaraguá do Sul, 2007. Disponível em: <http://www.weg.com.br>. Acesso em: 19 dez. 2007.

WHEELWRIGHT, S. C.; CLARK, K. B. Revolutionizing Product Development: Quantum Leaps in Speed, Efficiency, and Quality. New York: The Free Press, 1992. 364 p.

YIN, R. D. Estudo de caso: planejamento e métodos. $2^{\text {a }}$ Edição. Porto Alegre: Bookman, 2001. 


\section{ANEXO A - ROTEIRO DE ENTREVISTA}

Preparação anterior para cada empresa e entrevista:

- Verificar as linhas de produtos: quais os mercados, quais as plataformas, famílias de produtos, modelos.

- Verificar quantos e quais foram os novos produtos lançados nos últimos anos.

- Verificar quantas unidades a empresa possui para fazer desenvolvimento de produtos e se a gestão do portfólio é integrada ou independente.

- Verifique se a entrevista pode ser gravada. Se a entrevista for em grupo, pedir a cada participante que se apresente dizendo nome, departamento, cargo, tempo na empresa, tempo na função e suas principais atividades. Comentar que essa apresentação inicial serve para registrar essas informações e para identificar a voz da pessoa para posterior transcrição.

- Se for possível identificar os participantes com antecedência, tente levantar informações sobre formação, cargo, projetos que participou etc.

\section{- IDENTIFICAÇÃO:}

Empresa:

Nome do(a) entrevistado(a):

Departamento:

Cargo:

Tempo de empresa:

Tempo no cargo:

Principais atividades:

\section{- GERAÇÃO DE PROPOSTAS DE NOVOS PROJETOS}

1. De onde vêm as idéias para os novos produtos? Há alguém responsável na empresa por coletar e manter uma lista de idéias ou sugestões de novos produtos inovadores?

Justificativa: verificar se a empresa possui algum mecanismo estruturado para produção de propostas para projetos de novos produtos e como esse mecanismo está integrado à gestão do portfólio. Verificar se a empresa usa pesquisa de mercado, benchmark dos concorrentes, opiniões de clientes e parceiros, inovações inéditas etc.

2. Quantos projetos de novos produtos estão em andamento atualmente? Qual o montante de recursos destinados a esses projetos (e.g., \% do orçamento de P\&D)? Qual o montante de recursos destinados a melhorias, correções etc, em produtos já lançados?

Justificativa: verificar se a empresa realmente possui um portfólio de projetos de novos produtos, isto é, vários projetos em desenvolvimento simultâneo que concorrem pelos recursos da empresa. Diferenciar o percentual gasto para novos produtos do gasto para melhorias, correções etc. 
3. Existe algum sistema de informação que seja usado para o gerenciamento dos projetos e do portfólio (carteira) de novos produtos?

Justificativa: se existir algum sistema em uso, é preciso verificar se a empresa o utiliza apenas como suporte à decisão ou se usa funções de avaliação de projetos e do portfólio. Dependendo da intensidade de uso do sistema, o modelo de gestão do portfólio é praticamente determinado pelo sistema em uso.

\section{- DIRETRIZES ESTRATÉGICAS}

4. A empresa possui um planejamento estratégico para lançamento de novos produtos? Quem elabora esse plano?

Justificativa: identificar se a empresa possui uma estratégia específica para o lançamento de novos produtos, e conseqüentemente, para o seu desenvolvimento. Identificar quem elabora essa estratégia e verificar se essa estratégia direciona a seleção dos projetos em todas as etapas, para todos os departamentos da empresa que desenvolvem produtos.

5. Como a empresa garante que os projetos de novos produtos estejam alinhados com relação aos objetivos estratégicos do negócio?

Justificativa: identificar se a empresa tem uma estratégia explícita para o portfólio de projetos e se define diretrizes baseadas nessa estratégia para auxiliar na seleção dos projetos do portfólio.

\section{- ANÁLISE INDIVIDUAL DOS PROJETOS}

6. Dentre as idéias disponíveis para novos produtos, como a empresa seleciona os projetos nos quais vai investir seus recursos? Cada departamento tem autonomia para escolher os projetos ou essa escolha é centralizada?

Justificativa: obter do respondente qual o seu conhecimento geral sobre as práticas de seleção de projetos utilizadas pela empresa. Verificar se a empresa possui um processo único de gestão do portfólio ou se o processo está dividido por seus departamentos. Identificar também, no caso da autonomia dos departamentos, se há diretrizes estratégicas comuns. Identificar se há a percepção de que a gestão do portfólio é importante para o sucesso do negócio.

7. Que informações são normalmente utilizadas para avaliar um projeto de novo produto? Os projetos são sempre avaliados usando as mesmas informações ou depende do projeto?

Justificativa: identificar qual o teor das informações utilizadas para analisar cada projeto, se a empresa tem um perfil definido (análise financeira $\mathrm{x}$ análise qualitativa) ou se a empresa adota um tipo de análise diferente para cada projeto. Se a empresa utilizar um conjunto de informações diferentes para cada projeto pode ser difícil comparar os projetos entre si, o que por sua vez torna difícil analisar o valor gerado pelo portfólio em termos quantitativos.

8. Os projetos de novos produtos são classificados de alguma forma? Por linha de produto? Por grau de inovação? Mercado alvo?

Justificativa: identificar se a empresa usa alguma classificação para os projetos e se essa classificação tem ligação com a alocação de recursos para os projetos 
selecionados. Por exemplo, Cooper (1997) comenta sobre a divisão do orçamento total em buckets (partes) para cada tipo de projeto.

9. Como essas informações são coletadas e apresentadas? Como se evita uma sobrecarga de informações?

Justificativa: Cooper (1997) argumenta que as informações para análise de cada projeto devem vir de fontes confiáveis, uma vez que o sucesso de cada projeto e conseqüentemente do portfólio, depende da qualidade das informações usadas na análise. Por outro lado, devem-se usar apenas as informações estritamente suficientes para evitar uma sobrecarga e até mesmo certa confusão na análise dos projetos. Cada empresa deve ter um conjunto próprio de informações que utiliza para analisar um projeto. É importante verificar se a empresa sempre usa o mesmo mecanismo, por exemplo, o gerente de projetos fornece informações financeiras e técnicas, ou se para cada projeto há uma fonte diferente de informações.

10. Que áreas da empresa participam do processo de avaliação e seleção de projetos de novos produtos? (Marketing, Vendas, $\mathrm{P} \& \mathrm{D}$, Clientes, Assistência técnica etc).

Justificativa: identificar qual a composição das informações usadas para a seleção dos projetos de gestão do portfólio e se o processo de decisão é centralizado ou descentralizado.

11. A empresa se vale de técnicas financeiras, tais como VPL, TIR, Payback etc, para avaliar projetos de novos produtos? Ela utiliza essas técnicas para todos os projetos ou depende da situação?

Justificativa: identificar qual é o peso da análise financeira na seleção dos projetos.

12. A empresa usa alguma técnica de pontuação para avaliar os projetos de novos produtos? Justificativa: verificar se a empresa usa ferramentas de análise qualitativa, isto é, não financeira, e quais fatores entram nessa análise qualitativa.

13. Como é elaborado o planejamento de prazos e custos dos projetos de novos produtos? A empresa usa dados de projetos anteriores?

Justificativa: identificar qual a fonte de informações sobre prazos, já que o prazo representa indiretamente um custo e, portanto, é um dos recursos escassos que a empresa deve minimizar na busca do portfólio ótimo. Verificar se o prazo de desenvolvimento (time-to-market) é levado em conta explicitamente na análise de viabilidade dos projetos.

\section{- ANÁLISE DO PORTFÓLIO}

14. Como está organizado o P\&D da empresa? Quantos e quais departamentos? Quantas pessoas? Qual o investimento anual?

Justificativa: identificar como estão organizados os recursos disponíveis para desenvolvimento de novos produtos e tecnologias. Coletar informações para conferência com valores divulgados na imprensa. 
15. A alocação de recursos para os projetos leva em conta o tipo de projeto? A empresa possui orçamento alocado por tipo de projetos, famílias, linhas de produtos ou outra classificação similar?

Justificativa: detalhar se o orçamento total é dividido entre os projetos ou entre as categorias de projetos. Cooper insiste que a estratégia da empresa só faz sentido se o orçamento é efetivamente gasto com projetos alinhados com essa estratégia. Identificar se a empresa busca algum tipo de equilíbrio entre os projetos, por exemplo, entre projetos para mercado interno e projetos para exportação.

16. A seleção de projetos privilegia a análise individual de cada projeto ou considera a interação entre todos os projetos do portfólio?

Justificativa: identificar se a empresa divide a análise dos projetos em etapas, segundo o modelo de Archer e Ghasemzadeh ou de Cooper et al., analisando individualmente cada projeto, coletando informações, comparando os projetos e posteriormente analisando as possíveis combinações entre os melhores projetos.

17. A sinergia entre os projetos é considerada durante a avaliação? (compartilhamento de recursos, concorrência interna, manufatura compartilhada, tecnologias semelhantes etc).

Justificativa: verificar se há uma fase de avaliação conjunta dos projetos e que tipo de informação é usada nessa fase. Identificar quais as decisões tomadas de acordo com a sinergia entre os projetos.

18. A empresa já utilizou ou utiliza algum tipo de gráfico para visualizar o posicionamento de cada projeto no portfólio de projetos? Que tipo(s) de eixo(s) é(são) usado(s) nesse(s) gráfico(s)? Exemplo, gráfico de bolhas da probabilidade de sucesso x VPL.

Justificativa: identificar se os gestores usam algum tipo de ferramenta qualitativa para ter idéia do posicionamento de cada projeto no portfólio, qual o tipo de ferramenta, quais informações ela apresenta e de quais informações ela necessita para ser operacionalizada.

19. Como é determinada a prioridade de cada projeto do portfólio?

Justificativa: identificar se a empresa adota priorização na carteira e se essa priorização é decisiva na alocação dos recursos para cada projeto. Identificar quem determina a prioridade, se é centralizado ou se há autonomia dos departamentos.

\section{- REAVALIZAÇÃo dOS PROJETOS E DO PORTFÓlIO}

20. Há indicadores para acompanhar a evolução dos projetos? Quais?

Justificativa: identificar se há indicadores e quais são. Esses indicadores são fundamentais para as reavaliações dos projetos.

21. Os projetos são revisados periodicamente com relação ao alinhamento estratégico do negócio? Os indicadores dos projetos são utilizados?

Justificativa: verificar se há reavaliações freqüientes e qual a periodicidade. Verificar se os indicadores de projetos são efetivamente utilizados nessas análises e se as reavaliações levam em conta apenas a análise individual de cada projeto ou o contexto do portfólio, isto é, se há reavaliação de projetos ou se há reavaliação do portfólio como um todo. 
22. Já houve casos de cancelamento de projetos, ou projetos que foram temporariamente suspensos, depois retomados e lançados? Poderia citar exemplos?

Justificativa: verificar se a empresa efetivamente toma ações de realocação de recursos mediante reavaliação dos projetos no contexto do portfólio. Essa é uma característica fundamental de um processo de gestão do portfólio de projetos de novos produtos em empresas intensivas em tecnologia. Por essa resposta, também pode ser possível identificar se a empresa usa algum modelo do tipo Stage-Gate (Cooper) no processo de desenvolvimento de produtos. Se um projeto é cancelado ou suspenso temporariamente, a gestão do portfólio é que dirá qual entra no lugar e porquê.

\section{- RECURSOS DE P\&D E ESTRUTURA ORGAZACIONAL}

23. Como são escolhidos os integrantes da equipe de projeto, gerente e desenvolvedores? Justificativa: identificar se a empresa escolhe o gerente de projeto por competências requeridas pelo projeto, por experiência geral, por tempo de casa etc. Identificar quais os mecanismos de alocação de pessoas dentre os projetos e se isso tem relação com a priorização dos projetos. Particularmente no caso do gerente, verificar se ele é mencionado nas perguntas anteriores como fonte de informações para avaliação dos projetos, ou se ele é apenas responsável pelo desenvolvimento do projeto em si.

24. Cada projeto tem uma equipe de desenvolvimento própria ou há compartilhamento de equipes e desenvolvedores entre diferentes projetos?

Justificativa: verificar se há compartilhamento de pessoas entre os projetos, o que certamente causa conflitos e problemas como multitarefa danosa, exigindo gestão de conflitos por parte dos gerentes, o que, em casos extremos, pode determinar que um projeto seja suspenso temporariamente ou mesmo cancelado.

25. Como são administrados os conflitos resultantes da competição por recursos entre os projetos?

Justificativa: identificar o tipo de estrutura de projetos predominante (funcional, matricial forte ou fraca, por projetos, hipertexto etc). Identificar também se a priorização inicial do projeto no portfólio sofre modificações em função dos conflitos durante o desenvolvimento. Verificar se as práticas na gestão de conflitos têm impacto na gestão do portfólio.

26. Que mecanismos de comunicação são usados entre os integrantes do time do projeto? Há alguma ferramenta específica que ajude nisso?

Justificativa: identificar se há ferramentas de comunicação que auxiliem no desenvolvimento, no acompanhamento e geração de informações sobre andamento dos projetos. Essas informações podem ser usadas no cálculo dos indicadores, que por sua vez, podem ser usados na reavaliação do portfólio.

27. Como é realizado o gerenciamento do escopo do projeto? Há algum software de apoio? Justificativa: identificar possíveis fontes de informação para o gerenciamento dos projetos e se há ligação com a gestão do portfólio, por meio de indicadores, por exemplo. 


\section{- PERCEPÇÕES SOBRE AS PRÁTICAS DE GESTÃO}

28. Quais os fatores apontados como decisivos para o sucesso na gestão do portfólio de projetos de novos produtos? Poderia citar exemplos?

Justificativa: identificar de maneira macro, quais os fatores percebidos pelo respondente como decisivos para o sucesso da gestão do portfólio de projetos de novos produtos. Verificar se há a percepção de que o processo atual é adequado. A diversificação é importante? A empresa te que estar presente em diversos mercados?

29. Quais os fatores percebidos como causas de insucessos na gestão do portfólio de projetos de novos produtos? Poderia citar exemplos?

Justificativa: identificar problemas enfrentados pela empresa na gestão do portfólio, principalmente com relação à super-alocação dos recursos de $\mathrm{P} \& \mathrm{D}$, atrasos na entrega de projetos etc. Verificar se há percepção de que o processo atual precisa ser melhorado. 


\section{ANEXO B - MODELO DE RELATÓRIO PARA ESTUDO DE CASO}

Este modelo foi utilizado para elaborar os relatórios para cada uma das empresas. Esse relatório consolidou todos os dados primários e secundários utilizados na pesquisa e foi submetido à aprovação das empresas para uso e publicação nessa pesquisa.

Gestão do portfólio de projetos de novos produtos na empresa XXX

Por Rogério Souza da Mata

Ribeirão Preto, Dezembro de 2007.

\section{Índice}

\section{Lista de Figuras}

\section{Lista de Quadros}

\section{Introdução}

2.Breve histórico da empresa: dados e fatos

3.Planejamento estratégico de novos produtos e tecnologias

4.Categorização, seleção e priorização dos projetos

5.Acompanhamento dos projetos e revisão do portfólio

\section{Conclusões}

\section{Referências}




\section{ANEXO C - DADOS E FATOS SOBRE A ALFA}

A partir de 1977, a ALFA ${ }^{1}$ começou a exportar para a América Latina. Em 1981, começou a desenvolver tecnologia própria em parceria com universidades e centros de pesquisa. No ano de 1983, foi implantada a área de P\&D com a visão estratégica de consolidar conhecimentos sobre o produto. Em 1985, foram promovidos acordos tecnológicos com a Purdue University (USA) e Toulouse (França). Nos primeiros anos de 1990, antecipando-se à globalização da economia, a ALFA deu início ao processo de abertura de bases produtivas fora do Brasil e a conseqüente ampliação de sua estrutura global de vendas. No ano de 1992, a empresa obteve a Certificação ISO-9000.

\footnotetext{
${ }^{1}$ Nome fictício. O histórico completo foi omitido a pedido da empresa.
} 


\section{ANEXO D - DADOS E FATOS SOBRE A BETA}

A empresa BETA $^{1}$ conta com cerca de 1000 funcionários, sendo 130 deles dedicados a P\&D. Em 1986, a empresa percebeu que o protecionismo estatal criado pela Lei da Informática estava com os dias contados. Ele elevava os custos dos produtos no Brasil e os compradores não estavam dispostos a pagar mais por eles. A estratégia da BETA foi então buscar o mercado internacional. O processo de internacionalização iniciou-se pelos Estados Unidos em 1989, e pela Europa a partir de 1990. Em 2000, a empresa contava com subsidiárias nos Estados Unidos, México, Alemanha, França, Singapura e em Pequim.

A BETA figura entre as primeiras empresas brasileiras com patentes depositadas nos Estados Unidos. Hoje a empresa fabrica quase 100 modelos e tipos de equipamentos diferentes, agrega serviços de projeto, instalação e assistência técnica, além de desenvolver softwares, respondendo por $95 \%$ do faturamento da empresa. Em 2000, mais de um terço da produção da empresa era vendido no mercado internacional.

Atualmente a empresa possui filiais espalhadas por todo o Brasil, estendendo suas operações a centenas países por meio de seus representantes comerciais e subsidiárias. Além disso, também possui fábricas e P\&D no exterior. Nos EUA há uma subsidiária de P\&D, responsável pelo suporte na compra de componentes eletrônicos, acesso a novas tecnologias e desenvolvimento de produtos de forma autônoma e também em conjunto com a equipe de P\&D no Brasil. Essa subsidiária também é responsável pelo projeto e fabricação dos circuitos integrados comercializados e utilizados pela BETA em diversos de seus produtos. A empresa também possui subsidiárias no México, Holanda, China, Cingapura, Alemanha e Reino Unido.

A BETA possui uma hierarquia bastante achatada, com poucos níveis. Há um conselho de acionistas, composto pelos proprietários da empresa, que também ocupam os principais cargos executivos. O presidente comanda a empresa juntamente com a diretoria, composta por representantes das várias divisões da empresa. Dentre as diversas divisões a de Desenvolvimento sobressai no processo de planejamento estratégico e tomada de decisão com relação à gestão do portfólio de projetos de novos produtos.

\footnotetext{
${ }^{1}$ Nome fictício. O histórico completo foi omitido a pedido da empresa.
} 


\section{ANEXO E - DADOS E FATOS SOBRE A TIGRE}

Essa pesquisa se concentrou na TIGRE Tubos e Conexões, não levando em conta a Tigre Pincéis que também é parte do grupo TIGRE S.A. Ao longo de sua história é possível reconhecer algumas qualidades indiscutíveis dessa empresa: inovação e ousadia. Sua atuação na indústria vai além dos conhecidos tubos e conexões de PVC, que a empresa introduziu no Brasil, sendo um dos principais agentes do mercado da construção civil. A origem da empresa remonta a 1941 quando o fundador, João Hansen, comprou uma pequena fábrica de pentes de osso de chifre da marca TIGRE, em Joinville, Santa Catarina (SC). Nessa mesma época, começaram a aparecer no mercado brasileiro pentes feitos de plástico, que além de coloridos, também eram baratos (POSSAMAI, 2005). Após o término da guerra, com a introdução do plástico no Brasil, a empresa substituiu o osso de chifre pelo novo material. Em 1945, João Hansen comprou uma máquina injetora de plástico e criou o setor de ferramentaria para a execução de moldes usados na produção de pentes, boquilhas de cachimbos, piteiras para cigarros e charutos, leques, pratos e brinquedos, tudo em plástico rígido. Essa linha de produtos foi muito importante para a fase de capitalização inicial. Em janeiro de 1946, a empresa passa a se chamar João Hansen Júnior \& Cia. Ltda e já fabricava pentes, cachimbos e artefatos de massa plástica. Em 1949, por alteração no contrato social, surge a Cia. Hansen Industrial, formada por 10 acionistas, quando foram criadas, pelo governo federal, fortes barreiras alfandegárias para proteger a nascente indústria de base nacional, a reserva de mercado. Na época, também foi criado o BNDE, para dar suporte financeiro com empréstimos para as novas indústrias.

Entre 1952 e 1953, a TIGRE adquiriu as primeiras máquinas de extrusão e granuladores, o que viria a possibilitar o início da fabricação de mangueiras de PVC flexível, fitas e sacos de polietileno para embalagens, entre outros, entrando assim na fase do plástico flexível. Primeiro foram feitas mangueiras para jardins, depois para a distribuição de gás e para transfusões de sangue. Em 1956, foram realizados os primeiros experimentos na extrusão dos tubos de PVC, o que coincidiu com o início do governo de Juscelino Kubitschek, cujo espírito desenvolvimentista levou a indústria nacional a saltos de crescimento. Em 1958, na sua primeira viagem à Europa, João Hansen visitou a Grande Feira do Plástico em Hannover, na Alemanha, onde conheceu os tubos e conexões de PVC rígido e sua enorme utilidade em instalações hidráulicas. Por 160 mil marcos, João Hansen adquiriu uma máquina Reifenäuser- 
90 para estrudar tubos, uma Battenfeld-300 para injetar peças de PVC e uma trançadeira para produzir tubos flexíveis. No mesmo ano, a TIGRE lançou pela primeira vez no Brasil os tubos rosqueáveis de PVC, nos mesmos diâmetros dos canos de ferro que dominavam o mercado.

Uma tarefa bastante árdua enfrentada nos anos 60 foi romper o preconceito contra os tubos de PVC. Para tanto, foi realizado um grande programa de marketing, que incluiu desde o patrocínio de programas de rádio até propaganda nos principais jornais e revistas da época, sempre comparando os novos produtos com os tubos metálicos tradicionais. Em 1959, ao lançar as primeiras conexões de PVC, foi introduzido no mercado o conceito de sistema hidráulico ou linha completa. No início da década de 60 aposta em uma estratégia de diversificação com descentralização, apoiada em circunstâncias ambientais bastante favoráveis, como a criação do $\mathrm{BNH}$, destinado a financiar a casa própria e grandes programas de saneamento básico, gerando aumento substancial da demanda por tubos e conexões.

Em 1963 cria sua primeira subsidiária, a Cipla (Companhia Industrial de Plásticos), que passou a produzir mais de 40 itens de plástico flexíveis, peças para tratores e itens de acabamento para eletrodomésticos e para automóveis. Em 1964, é fundada a Transportadora Rodotigre S. A., cujos caminhões deveriam levar os produtos da empresa para todo o país, além de trazer para Joinville as matérias primas necessárias. No mesmo ano, aproveitando incentivos da SUDENE, implanta em Recife a Ciplanorte. Em 1969 inaugura sua quarta subsidiária, a Ciplacentro, em São Paulo e constrói, em Joinville, uma unidade destinada a produzir 1.000 ton/mês. Na década seguinte, a mesma estratégia foi mantida, com a constituição, em 1972, da Hansen Máquinas e Equipamentos, para produzir moldes e máquinas. Porém, em 1973, a primeira crise do petróleo coloca a TIGRE frente ao problema do suprimento de matérias primas, na época quase todas importadas. Isso a levou a constituir, no ano seguinte, em Nova York, a Eximplast Corporation, destinada a importar diretamente os materiais demandados pelas fábricas no Brasil.

Em 1974, associa-se a Plásticos Tupiniquim de Joinville e cria mais uma subsidiária, a Tigrefibra Industrial, passando a produzir, entre outros produtos, tanques para a indústria química. Ainda em 1974, inaugura em Rio Claro, interior de São Paulo, a segunda unidade da Ciplacentro. Em 1978 é fundada a Tubos e Conexões TIGRE da Bahia, em Camaçarí, mas que só viria a funcionar em 1984, quando do encerramento da produção da unidade de Recife. No ano seguinte, é inaugurada a segunda fábrica de tubos e conexões em Joinville.

No início de 1977, a TIGRE dá o primeiro passo além das fronteiras do Brasil, instalando no Paraguai a Tubopar, que atualmente atende $80 \%$ da demanda local. Mais recentemente, viria a abrir subsidiárias também na Argentina e Chile. Além das empresas 
subsidiárias na América Latina, comercializa com Nigéria, Angola, Porto Rico, Guatemala, Estados Unidos e Canadá. Atualmente, a Tigre detém 60\% do mercado Brasileiro de tubos e conexões de PVC e é uma das cinco maiores empresas do mundo no segmento (POSSAMAI, 2005). Por outro lado, pretendendo aumentar o grau de verticalização no seu principal negócio, a TIGRE adquiriu em 1981 a Brasivinil, que passou a fornecer 50\% do PVC consumido pelas unidades do grupo. O ambiente político-econômico da década de 80 mostrava-se bastante adverso para a TIGRE: altas taxas de inflação, surgimento de mais de 30 concorrentes, abertura do mercado nacional à importação de produtos e capitais estrangeiros e queda no consumo interno de seus produtos. Para enfrentar essa conjuntura, a TIGRE aprofunda o processo de desenvolvimento do grupo, buscando agora a modernização e a profissionalização de sua gestão que até então era estritamente familiar.

Institucionalmente, toda a atividade foi transferida para a Tubos e Conexões TIGRE S/A, controlada pela holding Hansen Industrial. A Rodotigre e a Hansen Máquinas tornam-se independentes e inicia-se o processo de informatização da administração da empresa. Em 1983, o fundador João Hansen Júnior passa a atuar como Presidente do Conselho Administrativo onde permaneceria até seu definitivo afastamento em 1991. Seu filho, Carlos Roberto Hansen assume a Presidência Executiva e passa a introduzir profundas mudanças na empresa, principalmente descentralizando as decisões, enxugando as estruturas funcionais, investindo em tecnologia e contratando uma grande empresa de consultoria para redefinir as diretrizes e metas da empresa.

A década de 1990 foi marcada também pela decisão de tornar-se líder em todos os países onde estivesse presente, o que foi uma decisão estratégica. Começou com o controle da empresa Fanaplas no Chile, o que conferiu à TIGRE a referência no mercado internacional. Porém, para ser líder no mercado chileno teria que ousar ainda mais. Assim, adquiriu em 1999 mais três empresas locais, absorvendo $41 \%$ do mercado naquele país (POSSAMAI, 2005).

O processo de redefinição iniciado por Carlos Roberto Hansen foi concluído em fevereiro de 1994 com a edição de um novo plano estratégico que, entre outros, redefinia a linha de produtos e concentrava a produção em 3 locais (Joinville, Rio Claro e Camaçarí). Em março de 1994, no início da implantação do novo plano, Carlos Roberto veio a falecer em um acidente aéreo, sendo substituído por seu irmão João Neto. O novo presidente redirecionou o plano de mudanças original, priorizando a redução de preços e custos operacionais e administrativos. Com essa mudança na estratégia da empresa o desenvolvimento de novos produtos foi relegado a segundo plano, sendo que o departamento de P\&D foi praticamente extinto. Em 1995, Rosane Maria Fausto Hansen, viúva de Carlos Roberto, assumiu a 
Presidência do Conselho e comandou a etapa final da reestruturação da empresa, que culminou com a nomeação do diretor industrial Francisco Amaury Olsen para o cargo de presidente da Diretoria Executiva, sendo o primeiro presidente sem nenhum vínculo familiar com o fundador. Pouco tempo depois, por volta de 1999, a TIGRE retoma suas atividades de desenvolvimento de produtos, criando um novo departamento de P\&D com a missão de retomar as inovações e lançar novos produtos.

Em 1998 a TIGRE iniciou operações fabris na Argentina, com a inauguração de uma nova unidade em Pilar. Completando o portfólio de conexões de PVC, em 1999 a TIGRE assume a Santorelli, conquistando 27\% do mercado Argentino. Outros investimentos foram realizados na Bolívia a partir do ano de 2000. Com a compra da Plasmar, a TIGRE deteve $70 \%$ do mercado Boliviano. "Todo este processo tem sido muito gratificante para a TIGRE, ao permitir uma base maior de exportação, o convívio com outras culturas, a incorporação de profissionais e competências, a conquista de novos mercados e excelentes situações de competição" (POSSAMAI, 2005). No quadro seguinte têm-se as localizações dos centros operacionais da TIGRE no exterior:

\begin{tabular}{|c|l|}
\hline PAÍS & \multicolumn{1}{|c|}{ CENTOS OPERACIONAIS NO EXTERIOR } \\
\hline Bolívia & 2 centros localizados em La Paz e Santa Cruz de la Sierra. \\
\hline Paraguai & 1 centro localizado em Lambaré. \\
\hline Argentina & 1 centro localizado em Buenos Aires. \\
\hline Chile & 2 centros ambos localizados em Santiago. \\
\hline
\end{tabular}

Quadro 22 - Centros operacionais da Tigre fora do Brasil.

Fonte: TIGRE (2007).

A TIGRE conta com aproximadamente 4000 funcionários, sendo 3500 no Brasil e 500 nas unidades do exterior. Em 2006 a empresa faturou R\$ 1,74 bilhão e para 2007 a expectativa de crescimento é de entre $7 \%$ e $8 \%$. Atualmente, cerca de $15 \%$ desse faturamento provém de novos produtos, com menos de cinco anos de lançamento, conforme dados fornecidos pelo gerente de PD\&E. 


\section{ANEXO F - DADOS E FATOS SOBRE A WEG}

Sendo uma das cinco maiores fabricantes de motores elétricos do mundo e uma das líderes em tecnologia em seu setor, a WEG S.A. apresentou uma taxa de crescimento muito maior nos últimos anos do que a média dos concorrentes. Com foco de atuação no mercado de sistemas eletro-eletrônicos industriais e de geração, transmissão e distribuição de energia elétrica, a WEG S.A., de Jaraguá do Sul (SC) obteve em 2005, faturamento bruto de R \$2,97 bilhões, $14 \%$ acima dos $\mathrm{R} \$ 2,60$ bilhões de 2004 e quase o dobro do valor registrado em 2002 , de R\$ 1,53 bilhão. O mercado interno foi responsável por $62 \%$ da receita total. As soluções englobam motores elétricos e sistemas de automação industrial; construção de subestações de energia elétrica e equipamentos e serviços para instalação de centrais geradoras hidrelétricas, termoelétricas e eólicas. Em 2006, a WEG investiu R \$ 180 milhões em projetos de modernização e expansão. Para 2008, a empresa espera investir mais R \$ 520 milhões em ampliação e modernização do parque fabril (WEG, 2007).

O retrato financeiro atual de umas das maiores empresas brasileiras, e certamente de uma das que mais inova em tecnologia, não podia ser melhor. A WEG anunciou um lucro líquido de $\mathrm{R} \$ 502,8$ milhões em 2006, 34\% acima dos $\mathrm{R} \$ 374,8$ milhões obtidos em 2005. O mercado interno cresceu $16 \%$ e foi responsável por $61 \%$ da receita bruta total, enquanto o mercado externo cresceu $23 \%$ em reais (36\% quando medido em dólares norte-americanos), representando 39\% da receita bruta. (ABIMAQ, 2007).

A WEG foi fundada em 16 de setembro de 1961, em Jaraguá do Sul, Santa Catarina. A fábrica de motores começou pequena, com um capital inicial equivalente a três fuscas, nove funcionários e três sócios. Mas isso não desestimulou Werner Ricardo Voigt, dono de uma oficina de conserto de motores, Eggon João da Silva, demissionário da gerência de uma indústria local, e Geraldo Werninghaus, um bom mecânico. Juntando as três letras iniciais de cada nome, eles batizaram a empresa, que oficialmente se chamava Eletromotores Jaraguá Ltda., e partiram corajosamente para a produção, que atingiu naquele ano 146 unidades (WEG, 2007).

Anos mais tarde, a empresa viria a ganhar uma nova razão social, a Eletromotores WEG S.A que fabrica também comandos e proteções, atuando ainda em automação de processos industriais, geração e distribuição de energia, além da produção de tintas e vernizes 
industriais. Em 1989 os fundadores passaram a compor o Conselho de Administração da empresa, delegando a Décio da Silva o cargo de Diretor Presidente Executivo da WEG (WEG, 2007).

Apenas dois anos depois foi implantado o Programa WEG de Qualidade e Produtividade (PWQP), em que se consolidou o processo da administração participativa. Esse conceito é aplicado desde o chão de fábrica até a diretoria, concretizando-se nos Círculos de Controle de Qualidade (CCQ) que, implantados desde 1982, passaram a fazer parte da cultura da empresa. O PWQP é um dos principais direcionadores estratégicos usados no processo de gestão do portfólio de novos produtos. O PWQP também é referenciado como o plano tático para novos produtos da empresa, contendo entre outras informações, a lista de projetos que a empresa selecionou para desenvolvimento.

Como resultado dessa organização em grupos, os colaboradores podem apresentar sugestões sobre segurança no trabalho, saúde e qualidade de vida, sendo que diversas dessas sugestões resultaram em novos processos de produção e em novos produtos, acarretando economia, produtividade e conquista de novos mercados. Parte desses ótimos resultados exerce forte influência sobre a cidade de Jaraguá do Sul, bem como nas demais cidades em que há fábricas da WEG, pois a distribuição de lucros aos colaboradores injeta capital em todos os setores da economia (ALMEIDA, 2004).

A participação da WEG no mercado mundial é de aproximadamente 4\%, considerando-se uma das cinco maiores do mundo (WEG, 2007). O processo de internacionalização da empresa pode ser estruturado em três fases:
a. Exportações via representantes e distribuidores no exterior;
b. Exportação via empresas controladas e, finalmente,
c. Desenvolvimento de parque fabril no exterior.

Oitava empresa brasileira mais internacionalizada, de acordo com o ranking da Fundação Dom Cabral, a WEG está presente em mais de 100 países, possuindo unidades fabris na Argentina, México, Portugal e China (FDC, 2003).

A exportação é realizada principalmente por São Francisco do Sul e Itajaí. O item mais crítico é o gargalo logístico: falta de contêineres, portos operando nos seus limites, navios muitas vezes modificando rotas porque o tempo de parada é grande. O Brasil continua sendo o centro produtivo da WEG, mesmo com a expansão da empresa no exterior. Nos próximos 3 anos, a empresa pretende investir mais de R 150 milhões na modernização e expansão dos parques fabris no Brasil. A estratégia da WEG é dividida em duas partes (IEDI, 2007): 
a. No Brasil, fornecer soluções industriais completas, como sistemas de automação e geração de energia;

b. No mundo, o foco é em motores elétricos e inversores.

Até o final da década de 1990, o mercado internacional era alcançado fundamentalmente por meio de uma agressiva política de exportação a partir das unidades brasileiras, basicamente localizadas em cidades da região de colonização alemã catarinense, que deu origem ao grupo: Jaraguá do Sul e Blumenau. A partir de 1999, porém, esta estratégia ganha um impulso adicional com a instalação de unidades de produção nos principais mercados mundiais, processo levado a efeito sempre a partir da aquisição de concorrentes. $\mathrm{O}$ primeiro na Argentina, comprando a firma Morbe, localizada na província de Córdoba (ALMEIDA, 2000 apud SILVA, 2005).

Logo após, seguiu-se a compra de uma unidade da ABB (Asea Brown Bovery) na Cidade do México, detentora de cerca de $20 \%$ do mercado mexicano de motores de baixa tensão (VARGAS, 2000 apud SILVA, 2005) e, já aqui buscando um melhor posicionamento internacional no segmento dos motores customizados, a compra de uma fábrica de motores especiais do grupo Efacec, na cidade de Maia, região metropolitana da cidade do Porto, em Portugal (MEURER, 2002 apud SILVA, 2005).

Em 2004, segue-se a aquisição da chinesa Nantong Electric Motor Manufacturing, localizada na província de Jiangsu, a cerca de 250 quilômetros de Xangai, especializada na fabricação de motores elétricos de baixa e medida tensão (KARAM, 2004 apud SILVA, 2005). A empresa também tem planos em relação à Índia. É um mercado muito fechado, mas como o país tem enfrentado problemas de fornecimento de energia elétrica, já reduziu impostos de importação de equipamentos para geração e transmissão o que deve favorecer a penetração de equipamentos exportados pelo Brasil (IEDI, 2007).

Outra aquisição importante anunciada em 2006 foi da fabricante de transformadores de força de grande porte e de subestações móveis e fixas, a empresa Brasileira TRAFO, com sede em Gravataí (RS) e uma unidade fabril em Hortolândia (SP). A TRAFO atingiu receita líquida de R\$ 155 milhões em 2006. A nova aquisição incorpora cerca de 400 novos colaboradores ao grupo WEG, que passa a ter mais de 16 mil no mundo inteiro (WEG, 2007).

A WEG possui diversas unidades de negócio, de acordo com a descrição seguinte:

- Divisão Motores: situada em Jaraguá do Sul, SC, é a líder latino-americana, detendo, em 1996, a participação no mercado nacional de 50\% dos motores monofásicos e $75 \%$ dos trifásicos (WEG, 2007). 
- Divisão Automação: fusão da antiga Divisão de Automação com a divisão de Acionamentos. Atua na fabricação de componentes elétricos de baixa tensão para comando e proteção de motores, desenvolve e fabrica uma linha completa de produtos para automação industrial, painéis elétricos e equipamentos para variação de velocidade. Produz ainda painéis para comando e proteção de motores ou cargas elétricas em baixa e média tensão (WEG, 2007).

- Divisão Energia: localizado em Blumenau (SC), atua na fabricação de transformadores e máquinas para o setor industrial, geração, transmissão e distribuição de energia elétrica (WEG, 2007).

- Divisão Tintas: situada em Guaramirim (SC), a empresa é líder do mercado nacional de resinas para adesivos e alimentos. Atua também no mercado de vernizes isolantes utilizados para impregnação de bobinas elétricas e esmaltação dos fios de cobre usados na fabricação de seus motores e transformadores (WEG, 2007).

- Divisão Exportadora: localizada em Jaraguá do Sul (SC), atua como exportadora dos produtos das outras divisões da WEG (WEG, 2007).

- Divisão Florestal: situada em Jaraguá do Sul (SC), sua atuação está direcionada para realização de projetos de reflorestamento. A produção anual de 25 mil metros cúbicos de madeira permite o fornecimento de embalagens para as outras empresas do grupo WEG (WEG, 2007).

Em seus parques fabris no Brasil, a WEG controla todas as etapas de sua produção, desde a fundição e a estamparia de metal, até a esmaltação e a embalagem. Em Santa Catarina, onde a empresa nasceu, se concentra a maior parte da produção, mas a partir de 2000, com a aquisição de fábricas no exterior, a WEG assume definitivamente o posto de multinacional brasileira. Dentre as diversas áreas e departamentos da maior unidade de negócios da empresa, a unidade de motores, duas sobressaem no processo de planejamento estratégico e na tomada de decisão com relação à gestão do portfólio de projetos de novos produtos: a Engenharia de Produtos e o P\&D. Os dois departamentos estão sediados na unidade de motores junto às unidades fabris de Jaraguá do Sul (SC).

De forma a delimitar as fronteiras desse estudo, foi escolhida a unidade de negócios de Motores. Além de ser a unidade mais antiga e tradicional, representa as raízes de todos os processos de gestão adotados também nas outras unidades de negócio. Pode-se afirmar que as principais inovações em processos, produtos e em gestão que permeiam todo o grupo WEG estão presentes na WEG Motores. Além disso, o faturamento da WEG Motores representa 
cerca de $50 \%$ do faturamento de todo o grupo. Segundo um dos gerentes de engenharia da WEG Motores:

A WEG Motores representa hoje uns 50\% do faturamento do grupo. Está caindo, lógico, porque as outras empresas do grupo estão crescendo. A área de Motores Industriais, por exemplo, hoje é a que tem o maior volume, tem a maior equipe. A minha equipe tem hoje 100 pessoas.

O departamento de Engenharia de Produtos e o departamento de P\&D, ambos localizados na sede da WEG Motores, exercem um papel determinante na gestão do portfólio de projetos de novos produtos. A WEG desenvolve uma política de grandes investimentos em tecnologia e aplica em média 3\% da receita líquida em Pesquisa e Desenvolvimento, valor que chegou a mais de $\mathrm{R} \$ 70$ milhões em 2006. Além de equipes próprias de pesquisadores, a empresa mantém diversos laboratórios, onde realiza ensaios e fabricação de protótipos, além de criar e manter a documentação técnica de cada produto. Paralelamente, incrementa relações de intercâmbio tecnológico com centros de pesquisa de universidades brasileiras e internacionais (WEG, 2007). Em seus cinco parques fabris no Brasil, a empresa controla todas as etapas da produção, desde a fundição e a estamparia de metal, a esmaltação dos fios e partes internas do motor, até a embalagem. Segundo o gerente de P\&D da WEG Motores:

A WEG é um anticaso sobre terceirização e horizontalização de atividades. Toda a operação da WEG Motores é extremamente verticalizada. Todas as empresas do grupo são rentáveis e contribuem estrategicamente para o crescimento. Portanto, não houve e não há razão para concentrar atividades ou terceirizar o que já fazemos bem. 